\title{
Mitigation of water quality and ecosystem impacts of roadway construction through retrospective engineering analyses
}

Jaime Monique Sayre

West Virginia University

Follow this and additional works at: https://researchrepository.wvu.edu/etd

\section{Recommended Citation}

Sayre, Jaime Monique, "Mitigation of water quality and ecosystem impacts of roadway construction through retrospective engineering analyses" (2001). Graduate Theses, Dissertations, and Problem Reports. 1133.

https://researchrepository.wvu.edu/etd/1133

This Thesis is protected by copyright and/or related rights. It has been brought to you by the The Research Repository @ WVU with permission from the rights-holder(s). You are free to use this Thesis in any way that is permitted by the copyright and related rights legislation that applies to your use. For other uses you must obtain permission from the rights-holder(s) directly, unless additional rights are indicated by a Creative Commons license in the record and/ or on the work itself. This Thesis has been accepted for inclusion in WVU Graduate Theses, Dissertations, and Problem Reports collection by an authorized administrator of The Research Repository @ WVU. For more information, please contact researchrepository@mail.wvu.edu. 
Mitigation of Water Quality and Ecosystem Impacts of Roadway Construction Through Retrospective Engineering Analyses.

\author{
Jaime M. Sayre
}

Thesis submitted to the

College of Engineering and Mineral Resources

at West Virginia University in partial fulfillment of the requirements

for the degree of

\author{
Master of Science \\ In \\ Civil and Environmental Engineering \\ Roger C. Viadero, Jr., Ph.D., Chair \\ Ronald H. Fortney, Ph.D. \\ Donald D. Gray, Ph.D., P.E. \\ Department of Civil and Environmental Engineering
}

Morgantown, West Virginia

2001

Keywords: Corridor H, Laurel Run, Acid Mine Drainage, Acid Rock Drainage, Highway Runoff, Mitigation, Prevention

Copyright 2001 Jaime M. Sayre 


\section{ABSTRACT \\ Mitigation of Water Quality and Ecosystem Impacts of Roadway Construction Through Retrospective Engineering Analyses}

Jaime M. Sayre

During the construction of a segment of Appalachian Corridor $H$ between Buckhannon and Elkins, West Virginia, mine spoils and land use features related to historic mining were disturbed. An assessment of the water quality, benthic macro invertebrates, and fish populations was conducted to ascertain the condition of the water and to assess the biological productivity of Laurel Run, a tributary of the Tygart Valley River which runs parallel to Corridor $H$. The water quality and biological impairments were attributed to the ineffective vegetation of the spoils pile, which permitted water infiltration and thus, served as a source of metals and acid. Through the assessment of water quality data collected below an abandoned mine bench located adjacent to the highway, it was determined that water seeps were also a source of dissolved metals, sulfate, acidity, and low $\mathrm{pH}$. Roadway construction through West Virginia and other coal producing states in the Mid-Appalachian region should be handled in a manner more like that of mining operations, with development and employment of similar preventative techniques to maintain environmental integrity, which includes roadway engineers thinking as miners by first identifying potential acidity and metal loading sources, and second by implementing the appropriate precautionary methods which are presented in this work. 


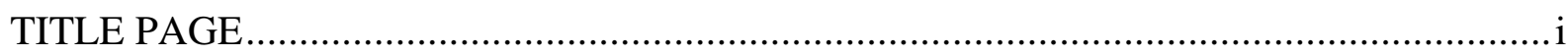

ABSTRACT ii

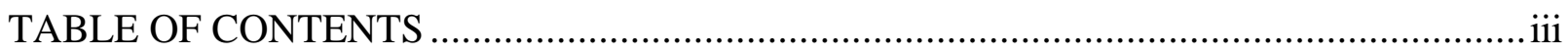

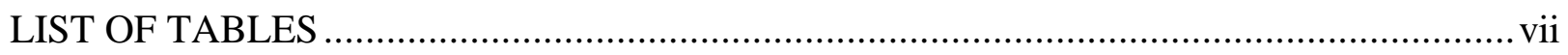

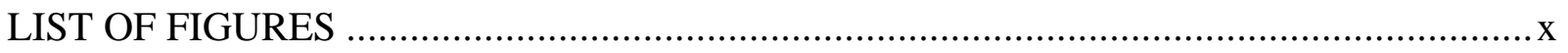

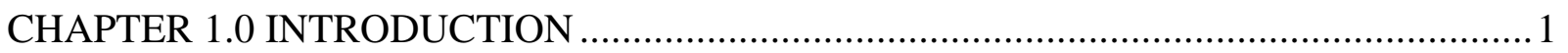

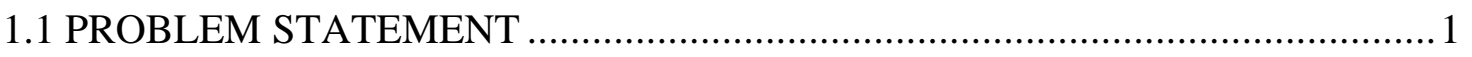

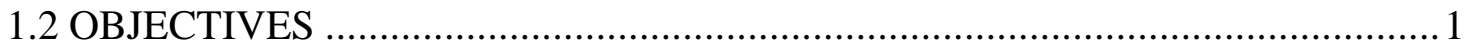

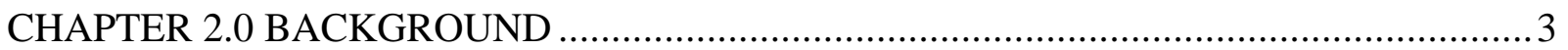

2.1 FACTORS AFFECTING RUNOFF WATER QUALITY ………......................... 3

2.1.1 General Factors Affecting Runoff Water Quality ................................... 3

2.1.2 Specific Factors of Potential Environmental Concern ............................. 5

2.2 ENVIRONMENTAL IMPACTS ON WATER QUALITY, BENTHIC

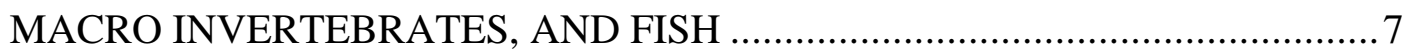

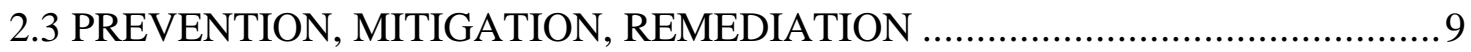

2.3.1 Prevention, Mitigation, Remediation of Roadway Construction .............. 9

2.3.1.1 Vegetative Controls............................................................... 12

2.3.1.2 Geotextiles and Mulches .................................................... 19

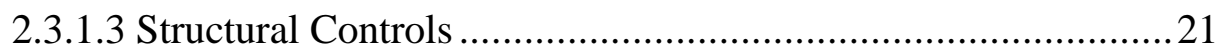

2.3.2 Prevention, Mitigation, Remediation of Acid Mine Drainage and

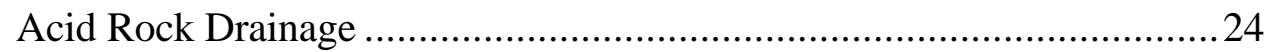

2.3.2.1 Prevention of Acid Mine Drainage and Acid Rock

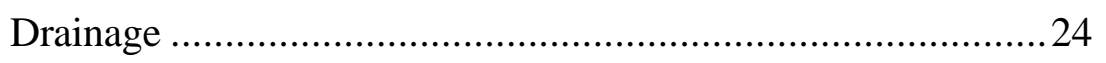

2.3.2.2 Mitigation and Remediation of Acid Mine Drainage and

Acid Rock Drainage ……………………................................ 30

2.3.2.2.1 Wetland Treatment Systems...................................... 30

2.3.2.2.2 Alkaline Producing Systems.......................................... 39

CHAPTER 3.0 EXPERIMENTAL APPROACH ............................................................ 42

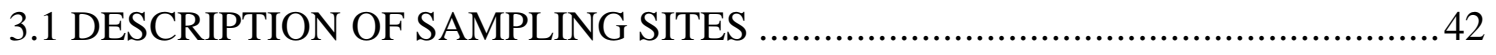




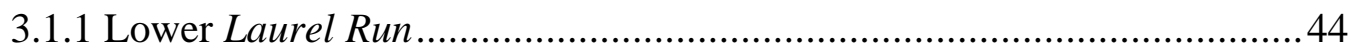

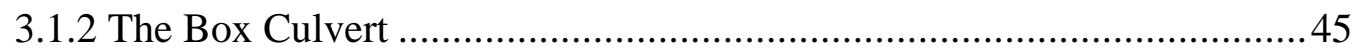

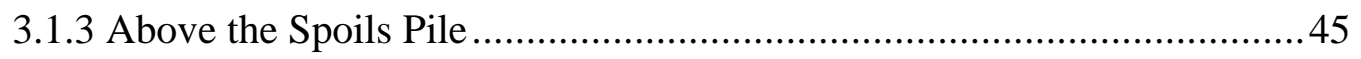

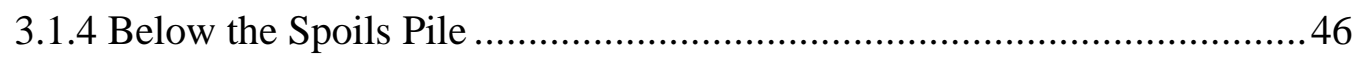

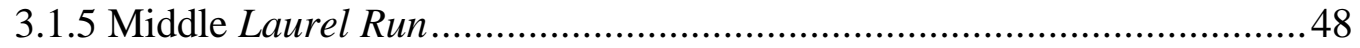

3.1.6 Above the Sedimentation Pond ............................................................. 48

3.1.7 Below the Sedimentation Pond............................................................. 49

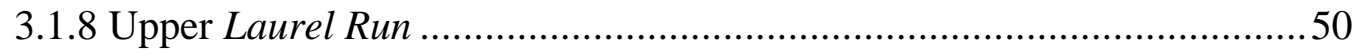

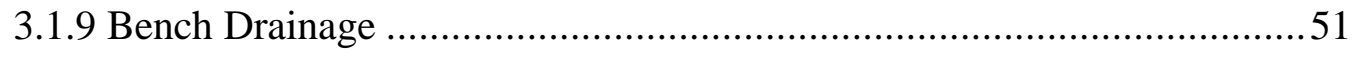

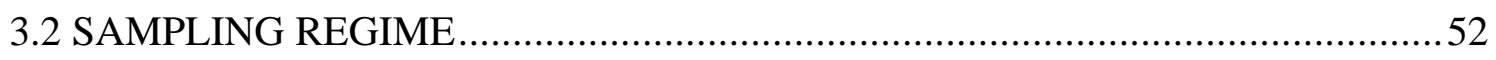

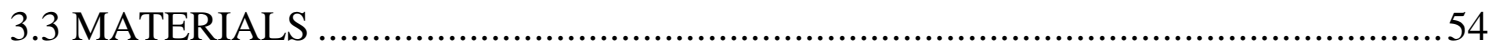

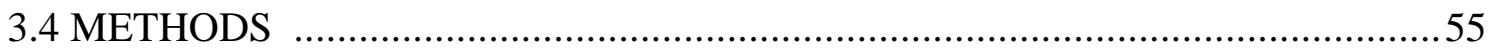

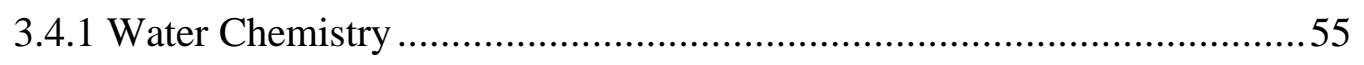

3.4.2 Macro Invertebrate and Fish Assessment ................................................57

3.5 QUALITY ASSURANCE AND QUALITY CONTROL ......................................6

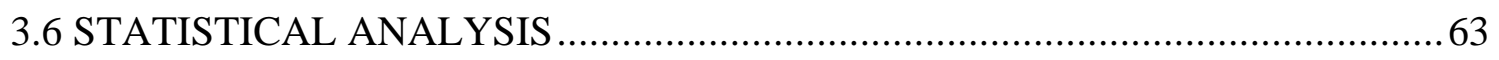

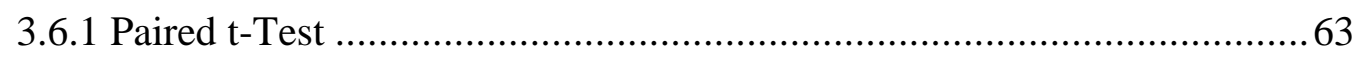

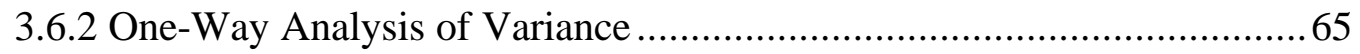

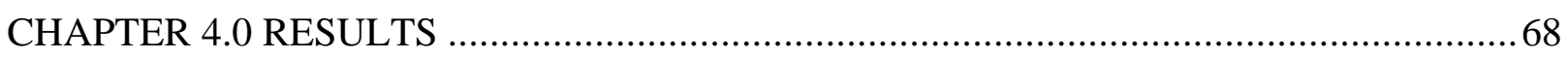

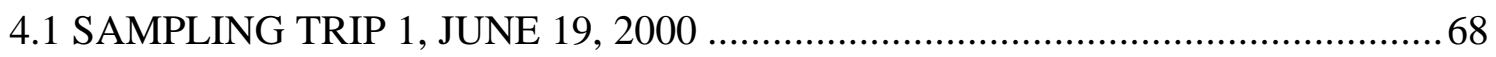

4.1.1 Site One: Lower Laurel Run, June 19, 2000 ............................................ 69

4.1.2 Site Two: Box Culvert, June 19, 2000 ………………………….......... 71

4.1.3 Site Three: Middle Laurel Run, June 19, 2000 ...................................... 72

4.1.4 Site Four: Upper Laurel Run, June 19, 2000.......................................... 73

4.1.5 Site Five: Bench Drainage, June 19, 2000 ............................................ 74

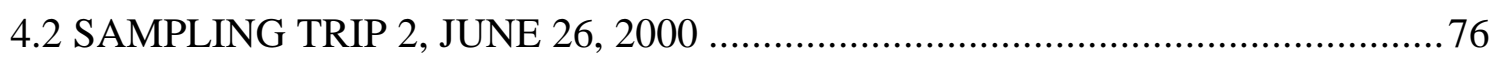

4.2.1 Lower Laurel Run, June 26, 2000 ........................................................ 78

4.2.2 The Box Culvert, June 26, 2000 .......................................................

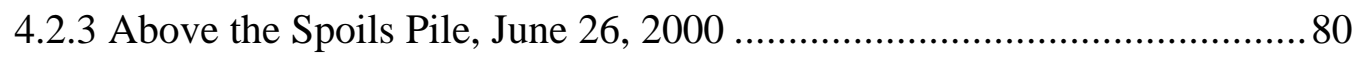

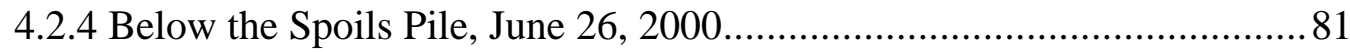

4.2.5 Middle Laurel Run, June 26, 2000 ....................................................... 82 
4.2.6 Above the Sedimentation Pond, June 26, 2000...................................... 83

4.2.7 Below the Sedimentation Pond, June 26, 2000 ……………………........ 84

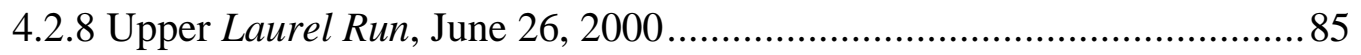

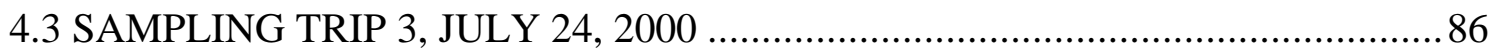

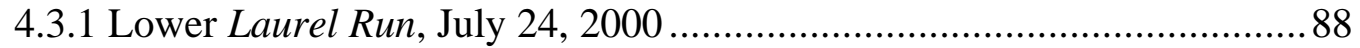

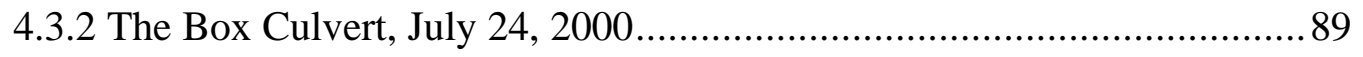

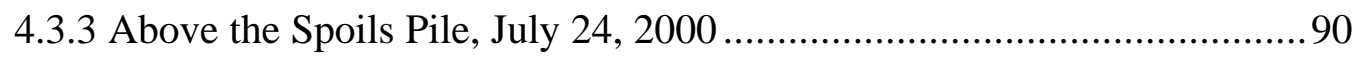

4.3.4 Below the Spoils Pile, July 24, 2000 ……………..................................91

4.3.5 Middle Laurel Run, July 24, 2000 ...................................................... 92

4.3.6 Above the Sedimentation Pond, July 24, 2000..................................... 92

4.3.7 Below the Sedimentation Pond, July 24, 2000........................................99

4.3.8 Upper Laurel Run, July 24, 2000.......................................................95

4.3.9 The Bench Drainage, July 24, 2000....................................................96

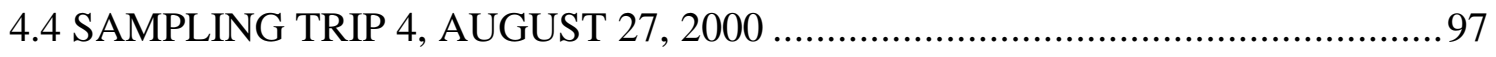

4.4.1 Lower Laurel Run, August 27, 2000 ................................................... 98

4.4.2 The Box Culvert, August 27, 2000 .....................................................99

4.4.3 Above the Spoils Pile, August 27, 2000 .................................................. 99

4.4.4 Below the Spoils Pile, August 27, 2000................................................. 100

4.4.5 Middle Laurel Run, August 27, 2000 ................................................... 101

4.4.6 Above the Sedimentation Pond, August 27, 2000.................................. 102

4.4.7 Below the Sedimentation Pond, August 27, 2000 ................................... 103

4.4.8 Upper Laurel Run, August 27, 2000 ..................................................... 104

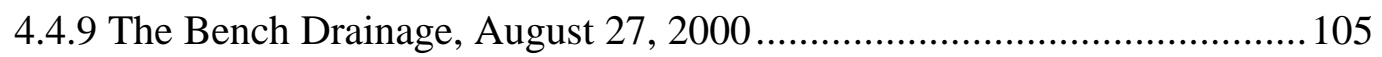

4.5 OBTAINING THE CONSTRUCTION PLANS...................................................... 106

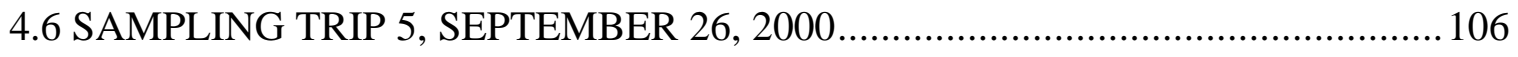

4.6.1 Lower Laurel Run, September 26, 2000 …………............................. 108

4.6.2 The Box Culvert, September 26, 2000................................................. 109

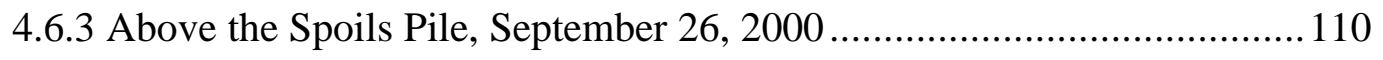

4.6.4 Below the Spoils Pile, September 26, 2000 ............................................ 111

4.6.5 Middle Laurel Run, September 26, 2000 ............................................... 112

4.6.6 Above the Sedimentation Pond, September 26, 2000 .............................. 113 
4.6.7 Below the Sedimentation Pond, September 26, 2000.......................... 114

4.6.8 Upper Laurel Run, September 26, 2000 ......................................... 115

4.6.9 The Bench Drainage, September 26, 2000...................................... 115

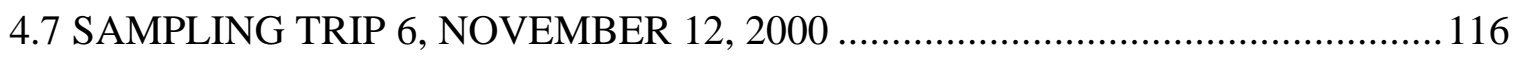

4.7.1 Lower Laurel Run, November 12, 2000 ........................................... 118

4.7.2 The Box Culvert, November 12, 2000.............................................. 118

4.7.3 Above the Spoils Pile, November 12, 2000 ........................................ 119

4.7.4 Below the Spoils Pile, November 12, 2000 ......................................... 119

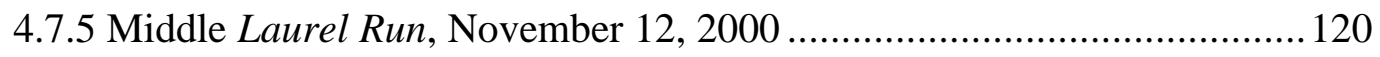

4.7.6 Above the Sedimentation Pond, November 12, 2000.......................... 121

4.7.7 Below the Sedimentation Pond, November 12, 2000.......................... 122

4.7.8 Upper Laurel Run, November 12, 2000.......................................... 123

4.7.9 The Bench Drainage, November 12, 2000 ....................................... 123

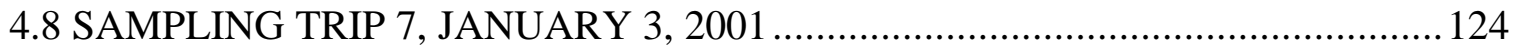

4.8.1 Lower Laurel Run, January 3, 2001 ................................................. 126

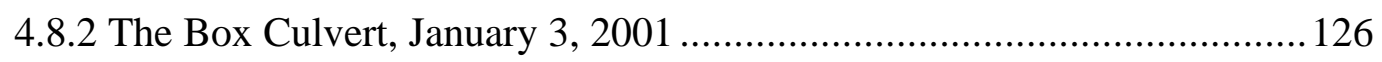

4.8.3 Above the Spoils Pile, January 3, 2001 ........................................... 127

4.8.4 Below the Spoils Pile, January 3, 2001 .............................................. 127

4.8.5 Middle Laurel Run, January 3, 2001 ................................................ 128

4.8.6 Above the Sedimentation Pond, January 3, 2001 ................................ 129

4.8.7 Below the Sedimentation Pond, January 3, 2001 ................................ 130

4.8.8 Upper Laurel Run, January 3, 2001 ............................................... 131

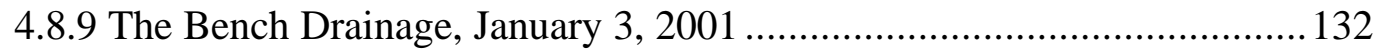

4.9 BENTHIC MACRO INVERTEBRATE AND FISH ASSESSMENT ................... 133

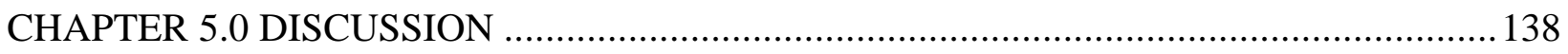

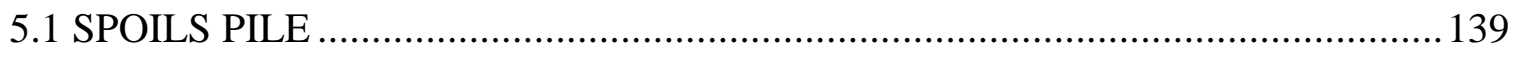

5.1.1 Impact of Spoils Pile on Water Quality ........................................... 140

5.1.2 Remediation Techniques for Spoils Piles...................................... 152

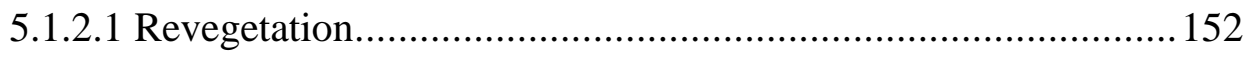

5.1.2.2 Wetland Treatment Systems ........................................... 155

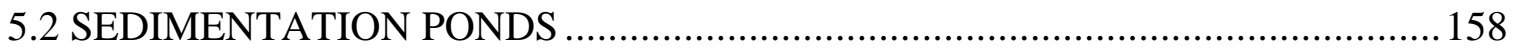




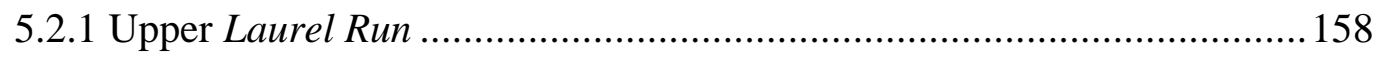

5.2.2 "Intact" Sedimentation Pond ................................................................ 159

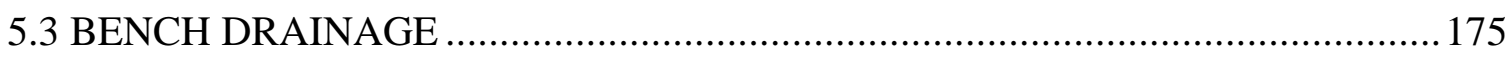

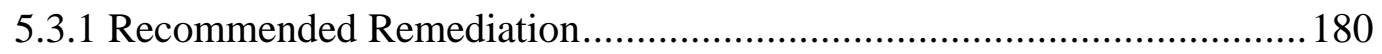

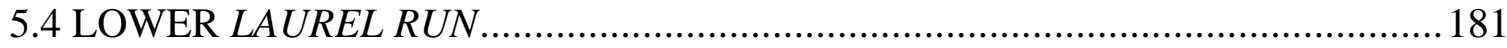

5.5 RECOMMENDED TECHNIQUES FOR FUTURE CONSTRUCTION ................. 189

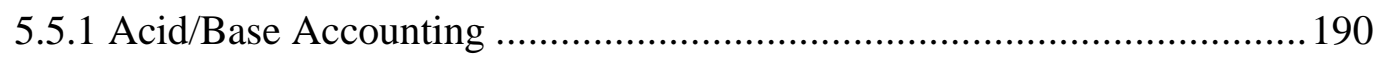

5.5.2 Selective Placement ……………........................................................... 191

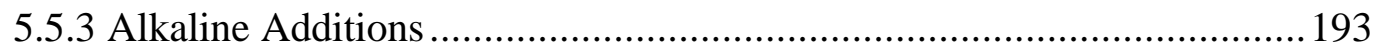

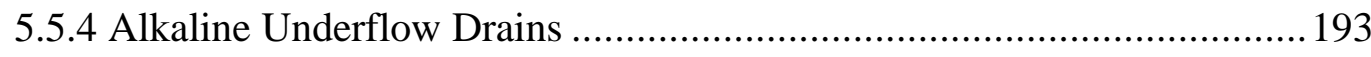

5.5.5 Realignment of the Highway .................................................................... 195

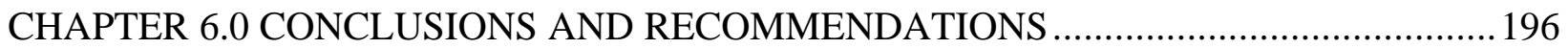

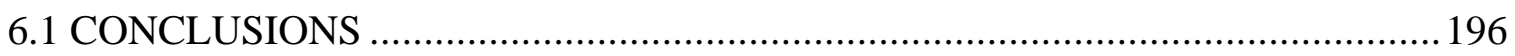

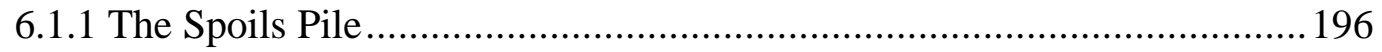

6.1.2 The Sedimentation Ponds...................................................................... 197

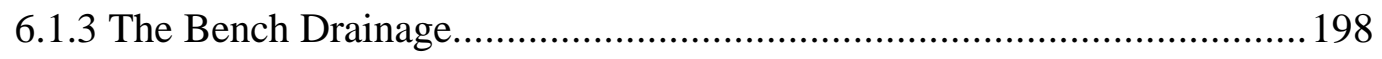

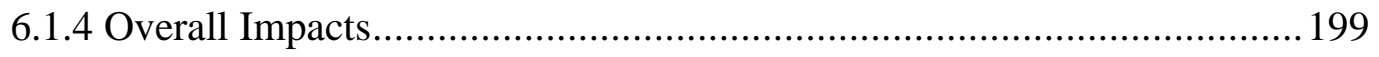

6.2 RECOMMENDATIONS FOR FUTURE ROADWAY CONSTRUCTION ............200

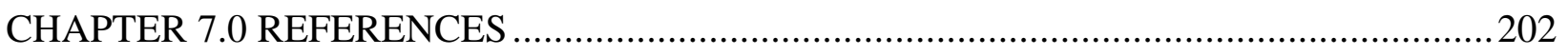

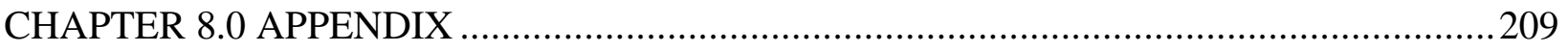




\section{LIST OF TABLES}

TABLE

PAGE

Table 2.1 Categories for ABA data (Ferguson and Morin 1991,

Ferguson and Robertson 1994).

Table 3.1 Meters, manufacturers, and laboratory use.

Table 3.2 Methods used to determine the water quality parameters.

Table 3.3 Classification of WVSCI metrics (USEPA 2000).

Table 3.4 The rating system for WVSCI (USEPA 2000).

Table 3.5 Percent error in recovery for each site and analytic procedure. $\quad 61$

Table 3.6 Percent difference between the triplicates for each site and analytic procedure.

Table 4.1 Summary of standard water quality criteria for freshwater organisms (Jenkins et al. 1995).

Table 4.2 Results of water quality analysis for June 19, 2000.

Table 4.3 Water quality data for the bench drainage for June 19, 2000. 75

Table 4.4 Results of water quality analysis performed on June 26, 2000. 77

Table 4.5 Water quality analyses for July 24, 2000.

Table 4.6 Results of water quality analyses for August 27, 2000.

Table 4.7 Results of water quality analyses for September 26, 2000. 107

Table 4.8 Results of water quality analyses for November 12, $2000 . \quad 117$

Table 4.9 Results of water quality analyses for January 3, 2001. 125

Table 4.10 Benthic macro invertebrate metrics for Laurel Run 134

Table 4.11 The filterer to shredder (F:S) percentage. 135

Table 4.12 The mean wet weight for Laurel Run as collected at each site. 135

Table 5.1 Percent change between sulfate, manganese, aluminum, and Magnesium for above and below the spoils pile. 
Table 5.2 Results of paired t-test conducted above and below the spoils pile.

Table 5.3 Comparison of anaerobic and aerobic wetlands (Skousen 2001). 157

Table 5.4 Water quality data Upper Laurel Run. 159

Table 5.5 Mean particle diameters for above and below the sedimentation 167 pond.

Table 5.6 Percent increase from above to below the sedimentation pond. 168

Table 5.7 Results of the paired t-test conducted above and below the $\quad 170$ sedimentation pond.

Table 5.8 Water quality at Lower Laurel Run sampling station. 182

Table 5.9 Results of the one-way ANOVA conducted on Lower 187 Laurel Run.

Table 5.10 Common chemical compounds and cost for AMD treatment 194 (Skousen et al. 1996).

Table 8.1 Appendix: Core samples relating to the sites sampled on 209 Laurel Run. 


\section{LIST OF FIGURES}

FIGURE

Figure 2.1

Passive systems for AMD treatment (Faulkner and Skousen 1994).

Figure 3.1 Laurel Run Watershed as located in West Virginia and along Corridor $\mathrm{H}$.

Figure 3.2 Schematic of the Laurel Run Sampling Sites and vicinity as surveyed by WVU-CEE researchers.

Figure 3.3 The Lower Laurel Run sampling station (Site 1).

Figure 3.4 The box culvert sampling station draining into

Laurel Run (Site 2).

Figure 3.5 The sampling station above the spoils pile (Site 2a).

Figure 3.6 The sampling station below the spoils pile (Site 2b).

Figure 3.7 The Middle Laurel Run sampling station (Site 3).

Figure 3.8 The sampling station above the sedimentation pond (Site 3a).

Figure 3.9 The sampling station below the sedimentation pond (Site $3 b$ ). 50

Figure 3.10 The Upper Laurel Run sampling station (Site 4). 51

Figure 3.11 The bench drainage sampling station (Site 5). 52

Figure 4.1 Particle size spectra for Lower Laurel Run (Site 1), 71 June 19, 2000.

Figure 4.2 Particle size distribution for the box culvert June 19, 2000. 72

Figure 4.3 Particle size distribution for Middle Laurel Run, June 19, 2000. 73

Figure 4.4 Particle size distribution for Lower Laurel Run (Site 1), 79 June 26, 2000.

Figure 4.5 The particle size distribution for the box culvert (Site 2), June 26, 2000.

Figure 4.6 Particle size distribution for Site 2a, above the spoils pile, June 26, 2000. 
Figure 4.7 Particle size distribution for Site 2b, below the spoils pile, June 26, 2000.

Figure 4.8 Particle size distribution for Middle Laurel Run (Site 3), June 26, 2000.

Figure 4.9 Particle size distribution for above the sedimentation pond (Site 3a), June 26, 2000.

Figure 4.10 Particle size distribution for below the sedimentation pond (Site 3b), June 26, 2000.

Figure 4.11 Particle size distribution for Upper Laurel Run (Site 4), June 26, 2000.

Figure 4.12 Particle size distribution for below the sedimentation pond (Site 3b), July 24, 2000.

Figure 4.13 Particle size distribution for above the spoils pile (Site 2a), August 27, 2000.

Figure 4.14 Particle size distribution for Middle Laurel Run (Site 3), August 27, 2000.

Figure 4.15 Particle size distribution for above the sedimentation pond (Site 3a), August 27, 2000.

Figure 4.16 Particle size distribution for below the sedimentation pond (Site 3b), August 27, 2000.

Figure 4.17 Particle size distribution for Lower Laurel Run (Site 1), September 26, 2000.

Figure 4.18 Particle size distribution for the box culvert (Site 2), September 26, 2000.

Figure 4.19 Particle size distribution for above the spoils pile (Site 2a), September 26, 2000.

Figure 4.20 Particle size distribution below the spoils pile (Site 2b), September 26, 2000.

Figure 4.21 Particle size distribution for Middle Laurel Run (Site 3), September 26, 2000. 
Figure 4.22 Particle size distribution for above the sedimentation pond (Site 3a), September 26, 2000.

Figure 4.23 Particle size distribution for Middle Laurel Run (Site 3), November 12, 2000.

Figure 4.24 Particle size distribution for the site below the sedimentation pond (Site 3b), November 12, 2000.

Figure 4.25 Particle size distribution for Middle Laurel Run (Site 3), January 3, 2001.

Figure 4.26 Particle side distribution for the site below the sedimentation pond (Site 3b), January 3, 2001.

Figure 4.27 Particle size distribution for the bench drainage (Site 5), January 3, 2001.

Figure 5.1 Turbidity above and below the spoils pile.

Figure $5.2 \quad \mathrm{pH}$ above and below the spoils pile.

Figure 5.3 Conductivity above and below the spoils pile.

Figure 5.4 Total suspended solids concentration above and below the spoils pile.

Figure 5.5 Alkalinity above and below the spoils pile.

Figure 5.6 Acidity above and below the spoils pile.

Figure 5.7 Sulfate concentration above and below the spoils pile.

Figure 5.8 Chloride concentration above and below the spoils pile.

Figure 5.9 Iron concentration above and below the spoils pile.

Figure 5.10 Calcium concentration above and below the spoils pile.

Figure 5.11 Total hardness concentration above and below the spoils pile. 146

Figure 5.12 Manganese concentration above and below the spoils pile.

Figure 5.13 Aluminum concentration above and below the spoils pile. 
Figure 5.14 Magnesium concentration above and below the spoils pile.

Figure 5.15 Turbidity above and below the sedimentation pond.

Figure 5.16 $\mathrm{pH}$ above and below the sedimentation pond.

Figure 5.17 Conductivity above and below the sedimentation pond.

Figure 5.18 Total suspended solids concentration above and below the sedimentation pond.

Figure 5.19 Alkalinity above and below the sedimentation pond.

Figure 5.20 Acidity above and below the sedimentation pond.

Figure 5.21 Sulfate concentration above and below the sedimentation pond.

Figure 5.22 Chloride concentration above and below the sedimentation pond.

Figure 5.23 Iron concentration above and below the sedimentation pond.

Figure 5.24 Calcium concentration above and below the sedimentation pond.

Figure 5.25 Total hardness concentration above and below the sedimentation pond.

Figure 5.26 Manganese concentration above and below the sedimentation pond.

Figure 5.27 Aluminum concentration above and below the sedimentation pond.

Figure 5.28 Magnesium concentration above and below the sedimentation pond.

Figure 5.29 Removal rates for given areas and overflow rates.

Figure 5.30 Turbidity at the bench drainage (Site 5). 176

Figure 5.31 $\mathrm{pH}$ at the bench drainage (Site 5). 176

$\begin{array}{lll}\text { Figure 5.32 Conductivity at the bench drainage (Site 5). } & 177\end{array}$ 
Figure 5.33 Total suspended solids concentration at the bench drainage (Site 5).

$\begin{array}{lll}\text { Figure 5.34 Acidity at the bench drainage (Site 5). } & 178\end{array}$

$\begin{array}{lll}\text { Figure 5.35 Sulfate, chloride, iron, manganese, and aluminum } & 178\end{array}$ concentrations at the bench drainage (Site 5).

Figure 5.36 Calcium, magnesium, and total hardness concentrations at the bench drainage (Site 5).

Figure 5.37 Turbidity at Lower Laurel Run (Site 1.) 183

Figure 5.38 $\quad \mathrm{pH}$ at Lower Laurel Run (Site 1.) 183

Figure 5.39 Conductivity at Lower Laurel Run (Site 1). 184

Figure 5.40 Total suspended solids concentration at Lower Laurel 184 Run (Site 1).

Figure 5.41 Alkalinity and acidity at Lower Laurel Run (Site 1). 185

Figure 5.42 Sulfate, chloride, iron, manganese, and aluminum 185 concentrations at Lower Laurel Run (Site 1).

Figure 5.43 Calcium, magnesium, and total hardness concentrations 186 at Lower Laurel Run (Site 1). 


\subsection{INTRODUCTION}

\subsection{PROBLEM STATEMENT}

During roadway construction of a segment of Appalachian Corridor $H$ between Buckhannon and Elkins, West Virginia, mine spoils and land use features related to historic mining were encountered. Water quality impairment and biological impacts were suspected. Consequently, an analysis of water quality and biological populations was conducted to ascertain the conditions of the waters on Laurel Run, a tributary of the Tygart Valley River, which runs parallel to Corridor $H$. Based on this assessment, recommendations were developed to minimize potentially adverse impacts to the water quality and biological populations during and after roadway construction projects in West Virginia and the Mid-Appalachia region.

\subsection{OBJECTIVES}

Roadway construction projects in West Virginia should be approached in a manner similar to mining operations, employing comparable preventive techniques in addition to post impact mitigation and remediation. In order to affect this paradigm shift, roadway engineers must begin to think more as miners by first identifying potential acidity and metal loading sources, and second by implementing appropriate precautionary methods. The main objectives of this study were:

- Establish water quality characteristics and biological productivity on Laurel Run by analytical water chemistry assays, benthic macro invertebrate assessment, and a study of fish populations. 
- Assess the contribution to water quality impairment and suppression of biological communities of a spoils pile consisting of excess fill from roadway excavation, an exposed mine bench, and two sedimentation ponds constructed to mitigate roadway runoff.

- Develop recommendations for the remediation and mitigation of existing sources of impairment and for the minimization of environmental impacts in future roadway construction through regions of geochemical conditions and land use patterns similar to those encountered at Laurel Run and specific to West Virginia. 


\subsection{BACKGROUND}

The effects of roadway runoff on water quality have been extensively studied over the past thirty years. Through these evaluations, common factors affecting water quality have been identified in the construction and post-construction stages. Among these factors, topography, hydrology, and soil geochemistry are the primary deciding aspects of how construction ultimately affects receiving body water quality. In an effort to eliminate or minimize the effects of roadway construction, operation, and maintenance, several remediation and mitigation practices have been implemented. The execution of the best management practices (BMPs) is determined by the aforementioned factors. Furthermore, storm water runoff from construction sites is an important component of nonpoint source pollution because soil losses from unprotected constructed sites are estimated to approach 1000 times the average natural rate of soil erosion (Smoot et al. 1992).

\subsection{FACTORS AFFECTING RUNOFF WATER QUALITY}

\subsubsection{General Factors Affecting Runoff Water Quality}

The amount of excavation, cut and fill, and grading required prior to roadway construction is determined by the site topography and regulatory slope design constraints (Dodson 1999). As the amount of grading and excavation increases, the potential for erosion and pollution due to sedimentation increases. Sedimentation is the process through which particles, carried by runoff waters settle to the bottom of the body of 
water. In combination with topography, watershed hydrology and site geochemistry can affect the runoff water quality.

Topography contributes to erosion and sedimentation, which transport other pollutants such as heavy metals and nutrients, which are associated with particle size distribution, offsite. Suspended sediment concentrations are correlated with turbidity (measurement of light transmission through water), which when high enough, can be a threat to aquatic life. The soils which will remain suspended in the stream and will be transported farthest in the runoff is determined by the size distribution of the particles in suspension. Smaller particles are suspended longer, and thus contribute to an increase in downstream turbidity. The particle size distribution of the mobilized sediment is determined by the characteristics of the parent soil (i.e., soil type, porosity, and permeability), storm intensity and duration, and path of the flow (Barrett et al 1998b).

Vice et al. (1969) studied the factors effecting sediment movement on a construction site in the Potomac River watershed in Virginia, a 4.54 square mile basin that was approximately six miles from the head of the Potomac Estuary. The weather in this area was typically warm during the summers, approximately $81{ }^{\circ} \mathrm{F}\left(27^{\circ} \mathrm{C}\right)$, and mild during the winters, 20 to $50{ }^{\circ} \mathrm{F}\left(-7\right.$ to $\left.10{ }^{\circ} \mathrm{C}\right)$. This climate led to wet conditions in the spring which produced over 65\% of the annual erosion (Vice et al. 1969). Guy (1964) discovered an increase in erodibility of approximately $240 \%$ during the month of April, and the ratio of storm event sediment yield to average sediment yield increased from 0.6 to 1.45 in Virginia. 


\subsubsection{Specific Factors of Potential Environmental Concern}

During the planning and routing stages of a highway, the existing condition of the soil and water should be evaluated. When the soil and water at a proposed construction site are impacted by acidic mine drainage and high metal concentrations, special measures should be taken in order to insure that the contaminants are not released into the environment.

West Virginia has experienced intensive mining over the past century and abandoned mine lands (AML) are common in the State. Abandoned mine lands are those mines that closed before the Surface Mining Control and Reclamation Act (SMCRA) of 1977 came into effect. Mines in West Virginia and the mid-Appalachian region can be classified three additional ways (Faulkner and Skousen 1998):

- Active mines are currently under permit by SMCRA that have not received a bond release.

- Released mines are mines that were permitted after 1977 and released from reclamation liability.

- Forfeited mines are those mines where the permit was revoked and the reclamation release bond was forfeited.

In West Virginia, the largest underground mine complexes are in Grant and Monongalia counties; over half the acid mine drainage (AMD) and acid rock drainage (ARD) flow is produced in Monongalia, Grant, Tucker, and Harrison counties. AMD/ARD waters are formed through contact with acidic shale, coal seams, and pyretic material (Faulkner and Skousen 1998). Aside from problems associated with low $\mathrm{pH}$, 
AMD waters usually have significant metal concentrations (e.g., iron, aluminum, and manganese).

Acid mine drainage is a problem during the mining of material which is rich in iron and sulfur. Pyrite, or iron sulfide $\left(\mathrm{FeS}_{2}\right)$, is the major iron-sulfur impurity found in mining byproducts. When pyrite comes in contact with water, a dilute sulfuric acid $\left(\mathrm{H}_{2} \mathrm{SO}_{4}\right)$ is formed which results in a yellow-brown discoloration of the water. The formation of acid mine drainage is presented in Equations 2.1 through 2.4.

$$
\begin{aligned}
& 4 \mathrm{FeS}_{2}(\Downarrow)+14 \mathrm{O}_{2}+4 \mathrm{H}_{2} \mathrm{O} \Leftrightarrow 4 \mathrm{Fe}^{2+}+8 \mathrm{H}^{+}+8 \mathrm{SO}_{4}{ }^{2-} \\
& 4 \mathrm{Fe}^{2+}+4 \mathrm{H}^{+}+\mathrm{O}_{2} \Leftrightarrow 4 \mathrm{Fe}^{3+}+2 \mathrm{H}_{2} \mathrm{O} \\
& 4 \mathrm{Fe}^{3+}+12 \mathrm{H}_{2} \mathrm{O} \Leftrightarrow 4 \mathrm{Fe}(\mathrm{OH})_{3}(\Downarrow)+12 \mathrm{H}^{+} \\
& \mathrm{FeS}_{2}(\Downarrow)+14 \mathrm{Fe}^{3+}+8 \mathrm{H}_{2} \mathrm{O} \Leftrightarrow 15 \mathrm{Fe}^{2+}+2 \mathrm{SO}_{4}{ }^{2-}+16 \mathrm{H}^{+}
\end{aligned}
$$

Therefore, two pathways for ferric iron to interact exist: through the formation of ferric hydroxide and the further reaction with pyrite to produce additional ferrous iron. The result of this is strong acids, which react with minerals in the soil, and create waters with increased hardness and total dissolved solids (Faulkner and Skousen 1998).

Assessment of the impaired waters must be made in a manner that will allow the best remediation or mitigation practice to be selected. Joyce and Ryan (1990) evaluated the most common treatment methods employed in Australia and determined that seven essential variables must be addressed in the assessment and remediation of acid mine drainage and associated metal contamination. The variables include hydrological regime, physical and geotechnical characteristics, acid mine drainage hydrogeochemistry, any operational mine requirements, environmental sensitivity of the site, corporate objectives of the mining company, and the public protection objectives of the regulator. By utilizing 
the plan, Joyce and Ryan predicted that a balance between environmental and social needs could be found.

\subsection{ENVIRONMENTAL IMPACTS ON WATER QUALITY, BENTHIC MACRO INVERTEBRATES, AND FISH}

Gupta et.al (1981) studied the concentration of metal contaminants in water as total versus dissolved metal concentration, where the total concentration was much greater than the dissolved concentration, indicating that metal ions were bound to sediment particles. Generally, metal cations are associated primarily with smaller sediment particles, revealing a direct correlation between particle size and metal concentrations which is demonstrated by sediment retained by detention basins and roadway drainage control structures (Price and Yonge 1995, Xanthopoulos and Hahn 1990, Gupta et al. 1981, Portele et al. 1982). Particle size distribution can be more than just a factor of erosion and sedimentation. Specific particle sizes were determined to absorb trace metals and hydrocarbons: lead and cadmium were contained by soils with distributions between 20 and 50 microns, and polycyclic aromatic hydrocarbons were absorbed by particles with sizes ranging from 6 and 60 microns (Xanthopoulos and Augustin 1992). Further, stream flow rate affects the particle-size distribution of the suspended sediment. As the stream flow rate increases, the stream can transport larger particles, which increases the turbidity and amount of sedimentation (Reed 1978). Kobriger and Geinopolos (1984) found high correlations between metals, especially lead, zinc, iron, and salting particulates with particle size.

Lui et al. (1999) conducted laboratory experiments to determine the dependence

of erosion on precipitation and soil properties. A rainfall simulator and flume were 
constructed in order to mimic various storm intensities. The soil composition was varied throughout the experiment to ascertain whether or not erosion was dependent upon the soil properties. Through these studies, Lui et al. determined that as the rainfall intensity increased, erosion increased; however, the amount of erosion decreased as the shear strength of the soil increased.

Barrett et al. (1995c) observed that particulates and sediment in runoff can cause problems by decreasing flow capacity in drainage ways, reducing storage volume in ponds and lakes, smothering benthic macro invertebrates, decreasing water clarity, and interfering with the respiration of small fish. Suspended solids also reduce light transmission, which limits in-stream photosynthesis and diminishes aquatic food supply and habitat. Portele et al. (1982) reported that either the suspended solids levels or the pollutants associated with the solids were responsible for the mortality in the fish, even though the suspended solids levels were lower than values normally considered harmful to fish.

Reed (1977) found that the primary response observed among the benthic macro invertebrates and fish communities was a reduction in both numbers of species and in organisms downstream from the roadway construction. Generally, erosion control measures as are commonly applied in highway construction were of limited value in preventing damage to stream communities, especially in the early construction stages. Chisholm and Downes (1978) recorded the effects of the construction of the Appalachian Corridor $G$ highway on the benthic population of a stream receiving construction runoff, which were severe depletion or destruction of the biological community. However, within a year, rapid repopulation and stabilization of the biological community had 
occurred as a result of revegetation practices and slope stabilizing. Stream sediments store heavy metals and are the primary source for the bioconcentration of metals (Van Hassel et al. 1980).

Jenkins et al. (1995) reported that benthic macro invertebrates and fish require a $\mathrm{pH}$ minimum of 6.5 in order to survive. Also, total suspended solids concentration should not exceed $80 \mathrm{mg} / \mathrm{L}$. The iron concentration should be less than $1.5 \mathrm{mg} / \mathrm{L}$ and manganese concentration should not be greater than $1.0 \mathrm{mg} / \mathrm{L}$ in order for a stream to maintain and support healthy aquatic life.

\subsection{PREVENTION, MITIGATION, REMEDIATION}

\subsubsection{Prevention, Mitigation, Remediation of Roadway Construction}

Barrett et al. (1995b) stated that water quality effects of highway runoff are site specific. The need for highway runoff remediation and mitigation strategies to reduce the sediment and pollutant loadings was identified through runoff water quality research. However, certain roadway-specific factors must be considered in the design of the treatment strategy. The selection of in situ treatment methods (e.g., settling basin, grannular media filtration system, and other solids separation devices) is primarily determined by the site specific particulate characteristics and loading rates. The selection of appropriate water quality and drainage measures requires identification of solid gradation, mass loading, surface area, and specific gravity of the soil at each site. Particle-size distributions, solids fractions, hydrographic loadings, particle counts, and specific gravity are required to design infiltration systems or settling basins (Sansalone et al. 1998). Driscoll et al. (1990) reported that surrounding land use is the most important 
general factor influencing pollutant loads in highway runoff and watershed waters. They found significant differences in highway runoff quality between urban areas and in rural areas. Unusual local factors can also influence the quality of runoff.

In terms of runoff and erosion created by highway construction and operation, preventive measures are limited. Preserving the natural vegetation and constructing along the contours of hillsides are the simplest and most common practices. The preservation of existing vegetation or the revegetation of disturbed soil immediately after construction is the most effective way to control erosion and can reduce the discharge of suspended sediments to one sixth (Metropolitan Washington Council of Governments 1998). However, the preservation of natural vegetation is not always practical and constructing along contours does not always prevent erosion and sediment-laden runoff. In the cases where natural vegetative cover must be removed, the exposed soil is prone to erosion.

There are two lines of defense to consider when attempting to control runoff. The first line of defense is controlling erosion; the second method is trapping mobilized sediments (Schueler and Lugbill 1990). Several methods of mitigation have been established as common practices to minimize sediment from construction sites: vegetative controls, geotextiles and mulches, and structural practices $(e g$., velocity dissipation, sediment capture, and storm water management). These techniques trap the sediment-laden runoff and allow the soil particles to settle before reaching a body of water, provide a grassy area for the dissolution of runoff water velocity and deposition the soil particles, and detour runoff around the construction site and exposed soil, thus reducing the amount of erosion. 
Maestri and Lord (1987) examined common mitigation practices in the State of Virginia and devised a set of guidelines for mitigation methods. Their research was based upon a need for abatement or treatment methodologies for pollutant constituents. Maestri and Lord found that the impacts of highway runoff were site and event (i.e., storm intensity or first flush) specific; therefore, the mitigation techniques applied must vary from site to site. The implementation of a highway runoff pollution management program to reduce the total pollutant loading that enters a certain receiving water was suggested by Maestri and Lord. Maestri and Lord evaluated several low cost highway stormwater runoff control measures such as elimination of curbs, reduction of direct discharges into receiving bodies of water, reduction in runoff velocity, vegetation of channels, and the establishment and maintenance of vegetation. These methods were proven to be economical, easily implemented, and effective runoff control practices.

Dodson (1999) identified a number of stabilization practices which included minimizing impervious surfaces, minimizing disturbed area, constructing the roadway in stages, matching existing land contours, using temporary stabilization (e.g., seeding or mulching), using final stabilization (e.g., permanent vegetation and swales), and waiting for snow and ice to melt prior to construction. Vegetative stabilization practices such as temporary seeding, sod stabilization, permanent seeding and planting, buffer zone, and preservation of natural vegetation may also be implemented. In cases where the growth of vegetation is not plausible, nonvegetative stabilization practices, such as mulches, geotextiles, chemical stabilizers, stream bank stabilizers, soil-retaining measures, and dust control may be employed (Dodson 1999). 
Schueler and Lugbill (1990) examined six sediment-trapping controls: 1.) The pipe outlet trap, 2.) The grassed outlet trap, 3.) The riprap outlet trap, 4.) The stone outlet trap, 5.) The grassed swale trap, and 6.) The storm drain trap. Of the six, the most commonly applied highway runoff control methods were the riprap and stone outlet traps.

Schueler and Lugbill found that six factors influence the removal capacity of the sediment trap. These factors include the particle size distribution since most controls can not remove the fine-grained soils. The geometry of the control is especially important for detention basins and settling ponds. Also important is to ensure minimal turbulence and short-circuiting and have an ideal length to width ratio of 5:1. The available storage in the control must be 1800 cubic feet for one upland acre. Standing water can help reduce the turbulence of incoming runoff; however it decreases the storage capacity, therefore, Schueler and Lugbill did not establish standing water as a positive or negative effect.

The construction site history influences the amount of storage capacity remaining in the control. Over time, the settling of soil particles decreases the storage volume of the basin. Sediment flocculation in the runoff is controlled by high concentrations of suspended soil particles, which increase interference effects, and thus increase the net settling velocity of the particles.

\subsubsection{Vegetative Controls}

The most common method of mitigation is the application of vegetative covers or filters. These are also known as grassy swales; however, technically, swales are ditches that have gentle slopes and cover large areas of land (Barrett et al. 1995a). Vegetative covers can be preexisting or planted after the construction process has been completed. 
Construction can be destructive to the natural vegetation; therefore site-specific preventive measures must be employed. Natural vegetation provides a natural buffer zone, thus minimizing erosion potential, protecting water quality, and providing aesthetic benefits (Dodson 1999). Vegetative controls are the only structures which treat the runoff as it is conveyed; therefore, these systems are recommended wherever possible as collection and conveyance links between treatment systems (Burch et al. 1985).

Horner (1985) stated that vegetated filters should control sedimentation and provide filtration of solids and plant uptake of dissolved organics and inorganics. These processes are promoted by intimate and extended contact between runoff flow and vegetation, which require a close-growing cover of water-resistant grassy species. Kobriger and Geinopolos (1984) supported this finding by reporting that metal and sodium concentrations were generally higher in topsoil layers than in substrate layers, but the filtration process varied in effectiveness with different soil types.

Reed (1978) conducted a five-year investigation of the effects of highway construction on five basins (tributaries of Conodoguinet Creek in central Pennsylvania, near Harrisburg). After the construction was complete, an evaluation of the implemented sediment-control techniques was made. Three practices were used on the five sites: seeding, mulching, and jute matting; check dams made of straw bales or rocks; and detention ponds. The detention ponds were either onstream ponds (ponds connected to the stream) or offstream ponds (ponds constructed above the stream to collect the runoff before reaching the stream). Reed (1978) found that the offstream ponds were most effective, reducing sediment loads and stream turbidity by $60 \%$. The onstream ponds decreased the sediment loading, but increased the natural turbidity by $25 \%$. The rock 
dams had the low sediment removal efficiency (5\%) and the use of straw bales did not show any improvement. Reed (1978) recommended that seeding and mulching be used to stabilize fill slopes and drainage swales.

Barrett et al. (1998b) compared filter strips to grassy swales. Filter strips have lower maintenance requirements. Grassy swales have broad, flat channels in which flow tends to concentrate in small, incised channels, thus reducing the effectiveness. Filter strips offer comparable pollutant removal to grassy swales; however, shorter amounts of grass are required in filter strips. Pools of water and persistently wet areas in the grassy swales can damage the vegetation and reduce the removal efficiency, while providing a breeding place for mosquitoes. A slope steep enough to prevent such standing water should be applied in the design of grassy swales. Poorly designed filter strips can result in soil exposure and erosion, removing vegetation from the filter, thus diminishing the effectiveness of the control. The presence of a sediment "lip", which forms where the pavement meets the grassy median, is another problem associated with filter strips. Over time, sediment accumulates at the pavement/median interface and forms a mound of soil which prohibits the stormwater from draining.

Yousef et al. (1985) tested the performance of the grassy swales at various sites in Orlando, Florida. The hydraulic efficiencies of the swales were determined based on the ability of runoff waters to infiltrate and percolate. During the early 1980s, several experiments were conducted to examine metal removal in grassy swales. Chemical spikes were added at the head of the swale and a constant head gravity flow was applied. The outflow of the swale was then tested for metal concentrations, including zinc, copper, lead, iron, chromium, cadmium, and nickel. The swale had a removal efficiency ranging 
from 70 to $90 \%$ for zinc, lead, iron, and cadmium. In contrast, $40 \%$ of copper was removed, $44 \%$ of chromium was removed, and the nickel decreased by approximately $30 \%$. Yousef et al. determined that a thin grass cover on the swale was more effective than a thick cover. Yousef et al. (1986) evaluated the performance of retention and detention ponds with designs based on hydraulic inflow and examined the phosphorus and nitrogen removal once the runoff entered the ponds. Yousef $e t$ al. found that an aerobic environment at the water-sediment interface enhanced phosphorus removal, facilitated nitrification and denitrification processes, and thus removed nitrogen more efficiently than an anaerobic environment. A two to three year period was required for the detention and retention ponds to reach optimum removal efficiency.

Wright et al. (1976) conducted several vegetative control experiments by varying grading techniques, mulching practices, and fertilizer and seed mixtures to determine which method was best for controlling erosion. The sites were located throughout Virginia on major interstates and highways. Sets of sites were designated for specific mitigation techniques. Each set contained locations with variable topography and grade. The sites were monitored over a three-year period, after which, Wright and his colleagues were able to report on which practice proved best. For the sites studied, Wright et al. (1976) determined that stair-step grading, producing a rough, loose surface provided an ideal environment for fast germination, growth, and plant succession. Plant growth was reported to be stronger on fill slopes than on cut slopes due to less compaction of the rock and soil. Wright et al. (1976) reported that crownvetch, sericea, and flat pea were appropriate legume species for soils with low $\mathrm{pH}$ and low organic material content. 
Dee et al. (1998) evaluated several BMP considerations in order to determine which was most applicable to the given situation. A bypass to Route 29 was proposed that would cross the Rivanna River Reservoir watershed, which served as the drinking water source for Charlottesville, Virginia. Dee et al. (1998) assessed traditional mitigation methods and decided to combine several for optimal performance. A "wet" retention pond was employed due to its high pollutant removal efficiency. The length to width ratio was $3: 1$; the outlet was wider than the inlet, side slopes of $3: 1$ for easy maintenance, a maximum of three feet of standing water remained in the basin, a dry sump was provided for pretreatment and for hazardous spill storage, and a sediment catchment of riprap was added to the inlet. Dee et al. (1998) also reported that rock check dams were employed to aid in the settling of particles and that grassy swales were used for turbidity reduction.

A well-designed, well-maintained grassed swale can remove up to $70 \%$ of total suspended solids, $30 \%$ of total phosphorus, $25 \%$ of total nitrogen, and $50-90 \%$ of various trace metals, such as copper, iron, and zinc (Schueler et al. 1991). Barrett et al. (1998b) reported removal efficiencies of $30 \%$ of total phosphorus, approximately $75 \%$ of total suspended solids and volatile suspended solids (TSS and VSS, respectively), and 50-75\% of metals (copper, iron, and zinc). Little et al. (1982) found similar removal efficiencies of at least $65 \%$ for TSS and VSS. Many of the highway runoff constituents, including oxygen-demanding materials, the level of biochemical and chemical-oxygen demand, and hydrocarbon compounds are rapidly degraded in the aerobic environment of a vegetative control. Most particulates are incorporated within the soil layer rather than on the surface of the vegetation. Plants grow through the accumulated sediment and bind the 
constituents to the soil matrix with their root systems (Barrett et al. 1998b). Yousef et al. (1985) reported that pollutant removals are predominantly attributed to sorption, precipitation, filtration, coprecipitation, and biological uptake processes, which are chemical transport mechanisms. Mass removals of metals, nitrogen, and phosphorus were directly correlated to infiltration losses and onsite storage.

Vegetative controls should protect the surface soil from rainfall penetration and direct contact with erosive runoff. Other important functions of the vegetative filter include dispersing storm runoff flow and decreasing the velocity of the surface flow. With the application of a vegetative control, infiltration is enhanced, the soil's porosity and capacity to retain moisture through the plant roots is improved, and the soil is physically held in place by the roots. Further, transpiration or the conduction of moisture into plant tissue is promoted. Ultimately, erosion is reduced and sediment is allowed to deposit in the vegetative control (Dodson 1999).

Carlstrom (1982) evaluated the use of wetlands to treat highway runoff. Four types of wetlands were studied: an agricultural field of grass (Pheleum pratense L.), an abandoned cornfield (Zea mays L.), a pine stand (Pinus rigida Mill.), and an oak-pine forest (Quercus alba L., Quercus coccinea Muenchh, and Pinus rigida Mill) (Woodwell 1978, Carlstrom 1982). The forested areas showed the greatest removal of nutrients and organic matter (approximately 34\%) (Woodwell 1978). Oxygen demand was found to be dependent upon the hydraulic retention time, the depth of the standing water in the wetland, the plant and animal species living in the wetland, and the soil substrate and composition (Carlstrom 1982). A wetland pond with rush (Spirpus spp.) as the main 
plant species was found to have displayed BOD and COD reductions that were greater than $95 \%$ after eight days retention time (de Jong 1976, Carlstrom 1982).

The selection of vegetative controls is highly site specific. Temporary seeding, one method of vegetative control, is ideal for areas that have been disturbed and are likely to be disturbed again through construction completion, operation, and maintenance. This practice involves growing short-term vegetative cover consisting of fast growing grasses whose root systems hold down the soil (Dodson 1999). Typically, this is not an effective method in arid and semi-arid regions because the climate prevents fast plant growth.

Establishing grass is a second option which requires grading operations to be planned around optimal seeding dates for a particular geographical region. A third method, permanent seeding and planting is the most common application of a vegetative control. Permanent seeding is effective because the plants stabilize the soil by holding the soil particles in place. This control is appropriate for any graded or cleared area where a lengthy plant life is desired. Permanent seeding is especially important in filter strips, buffer areas, vegetated swales, on steep slopes, and along stream banks (Dodson 1999).

A fourth method to vegetate an area is sodding. Sod stabilization is appropriate for any graded or cleared area that might erode and where permanent plant cover is needed immediately. When installed correctly, sod can be $99 \%$ effective in reducing erosion, making it the most effective vegetative control available (USDA Natural Resources Conservation Service 1985). However, sod is costly, sensitive to climate, and requires routine watering and fertilizing. 
A fifth type of vegetative control is the construction of a buffer zone. Buffer zones are natural or planted vegetation strips at the top and bottom of a slope, outlining property boundaries, or juxtaposed to receiving waters. Buffer zones can reduce flows at critical runoff points, decreasing erosion and allowing sedimentation in the buffer zone boundaries (Dodson 1999).

\subsubsection{Geotextiles and Mulches}

Barrett et al. (1998a) evaluated the use of geotextiles for temporary sediment control. Initially, the performance was assessed during comprehensive field monitoring; however, difficulties obtaining representative water quality samples led to the initiation of laboratory experimentation. The number, size, and character of accessible pores and the thickness of the geotextile fabric were the primary limiting factors in filtration efficiency. Larger pore sizes allowed a greater flow and larger particles to pass through; however, smaller openings inhibited flow and increased retention times (Crebbin 1988).

Barrett et al. (1998a) conducted sediment experiments using a silt fence made from filter fabric. Laboratory experiments involved pilot-scale tests in which a flume was constructed to mimic a roadside slope of $0.33 \%$. A silt fence was constructed at the lower end of the flume and a rapid-mixing tank was placed at the head of the flume. Water was supplied to the mixing tank from an elevated water tank and a slurry tank. The removal efficiency reportedly improved with time. As fewer fabric pores were open to permeation, the flow decreased. The sediment was pooled behind the silt fence and allowed a maximum settling time of approximately 120 hours. Mean sediment removal efficiency ranged from 68 to $90 \%$ and was correlated with the hydraulic detention time. 
On a mass loading basis, total suspended solids on a construction site are such that a $75 \%$ sediment removal efficiency would still leave a large fraction of sediment in the discharge (Barrett et al. 1998a).

Horner et al. (1990) evaluated the effectiveness of several mulches and geotextiles. Straw, when applied alone, minimized rain impact, regulated soil temperature, and helped conserve soil moisture. The straw fibers were interwoven to trap soil, thus reducing the effects of water and wind erosion, promoting water infiltration, and enhancing vegetation growth. Straw should be applied when the need for erosion protection is immediate and for a relatively short period of time (typically less than three months.)

The addition of mulch and fertilizer to straw is highly effective in reducing erosion and preventing metals transport with the eroded soil, but is ineffective in reducing the amount of phosphorus and organic releases due to the nutrient content of fertilizers and mulches. Therefore, caution should be taken when applying this technique in areas where surface runoff will discharge to a body of water sensitive to nutrient additions and oxygen depletion. Mulches are available in various forms. One common form is the wood fiber mulch, which when applied alone does not provide much erosion protection due to the small size of the fibers. Wood fiber mulch is not an appropriate control to absorb the force of raindrops and flowing water, but can assist in plant establishment (Horner et al. 1990).

A third technique evaluated by Horner et al. (1990) was the application of a jute mat. A jute mat is an unbleached synthetic geotextile without chemical treatment, which decomposes in two years or less. The fibers in the mat absorb water, retain the water, and 
then slowly release the water over time. Through this process, surface runoff and erosion are reduced. The synthetic fiber blanket is typically made of very fine nonwoven polypropylene fibers reinforced with a polypropylene net. This technique is not ideal for areas experiencing rapid soil degradation or where quick incorporation of vegetation into the soil is necessary.

\subsubsection{Structural Controls}

Installation of special devices to divert, store, or limit runoff are know as structural controls. The main objectives of structural controls are to prevent water from flowing into erosion prone areas and to reduce the removal of sediments before the runoff exits the site (Dodson 1999). Four categories of structural controls are velocity dissipation, sediment capture, and temporary and permanent storm water management. As the velocity of the runoff increases, the quantity and size of the soil particles carried by the flow increases, under the convective flow of water. By dissipating the velocity, infiltration is promoted, the shearing forces exerted on the soil are reduced, and the runoff flow rate is attenuated.

Dodson (1999) identified several mechanisms that can be employed to attenuate the velocity. General velocity reduction results from slope reduction or use of the most gradual grades plausible for the site. Steep slope protection through the use of gradient terraces or flow diversion techniques, vegetation, or decreasing channel flow velocity are other methods of velocity dissipation. Velocity dissipation can be obtained by level spreaders, which disperse concentrated flows into an area stabilized by vegetation; outlet protection, in which erosion is reduced at the outlet of culverts or paved channels; check 
dams, in which small dams are constructed across drainage areas to slow the rate of flow; surface roughening, in which horizontal grooves are created parallel to the contours of the land; and gradient terraces, in which erosion damage is minimized by collecting the runoff on a level platform and diverting the flow to a stable area.

Sediment capture measures are installed to remove the sediment from the runoff before exiting the construction site. Sediment traps are ponds or impoundments placed across a low area or drainage swale. Sediment traps are suitable for perimeter controls during the primary stages of construction (Dodson 1999). The sediment basin is the sediment capture control most suitable for large areas of disturbance (Portele et al. 1982, Reed 1980, Schueler et.al 1991). Based on EPA general permitting requirements, basins serving areas of 10 acres or more are required to have a volume capable of containing the runoff calculated using 2-year, 24-hour storm data and a site-specific runoff coefficient determined for the area. By implementing a sedimentation basin, properly sized for the expected runoff, the total suspended solids concentration would be decreased as the particles are allowed settling time, and the metal concentrations may also be attenuated by settling of smaller particles which are reportedly more likely to adsorb metal ions (Portele et al. 1982). A functioning sedimentation pond is most effective at trapping $70 \%$ of the sediment that is carried into it during most storms (Reed 1980). Heavier sediments and pollutants, which have settled during earlier storms, may wash out during subsequent rainfall-runoff events, therefore creating a source instead of a sink for pollutants (Dorman et al. 1988). The amount of treatment in a sedimentation pond is moderate, but highly variable, depending on detention time and the fraction of the runoff effectively detained (Schueler et.al 1991). 
Horner et.al (1990a) reported that the best removal performance was achieved with a length/width ratio of 5:1. This was supported by findings by Reed (1980) and Nawrocki and Pietrzak (1976). Wanielista et al. (1988) suggested that sedimentation ponds be designed to optimize groundwater inflow into the basin.

Temporary storm water management measures are those controls which divert off-site runoff around the erosion prone area. Thus reducing the amount of storm water which crosses the exposed soil, resulting in erosion. Earthen dikes can be applied to protect work areas from upslope runoff. Earth dikes are typically constructed from compacted soil and stone, riprap, or vegetation. Interceptor dikes and swales are a combination of ridges of compacted soil and excavated depressions applied to the perimeters of the construction sites in order to reduce the storm water flow over the site's exposed soil. Other temporary measures include the installation of storm drains to divert flow to sediment-trapping devices. A slope drain can also be used to discharge runoff into a stabilized area, thus effectively reducing risk of soil slides. Another temporary control is a subsurface drain consisting of a perforated pipe or conduit placed under the surface of the ground, designed to remove excess water from the site by lowering the water table (Dodson 1999).

Wigington et al. (1983) identified detention basins as a BMP for urban runoff. The detention basin was favored over other methods because runoff is collected, soil particles are allowed to settle, and water is absorbed by the basin's soil walls. Wigington et al. also studied the metal removal efficiency of the detention basin and determined the depth of the accumulation of lead, zinc, copper, and cadmium in the soil. Wigington et al. reported that cadmium and copper were only present in the first zero to five 
centimeters of soil. However, zinc and lead were present in soils as deep as 15 - 30 centimeters. Vegetated swale drains were also evaluated in the Washington D.C. area as BMPs by Wigington et al. (1986). Studies similar to those reported earlier were conducted to determine the depth of the metal (lead, zinc, copper, and cadmium) accumulations. Results were comparable to Wigington's work on detention basins.

Permanent storm water management measures are normally installed during the construction process and continue to reduce pollutant loadings in runoff water after construction has been completed. One process of permanent runoff management is onsite infiltration. Infiltration and percolation basins are used to reduce peak runoff water discharges and protect downstream channels from erosion. These basins can change the watershed hydrology by regulating the levels of groundwater and stream flow that permeates from the basin. Wet ponds and artificial wetlands are designed to maintain a permanent inflow of water and have high removal rates of sediment, biochemical oxygen demand, organic nutrients, and metals (Dodson 1999).

\subsubsection{Prevention, Mitigation, Remediation of Acid Mine Drainage and Acid Rock Drainage}

\subsubsection{Prevention of Acid Mine Drainage and Acid Rock Drainage}

As the state of knowledge of acid mine drainage and acid producing rock develops, new forms of prevention have been developed. Most AMD/ARD prevention techniques have been evaluated for application to surface mining operations. Common preventive

measures include acid-base accounting, application of selective handling and placement of acidic waste materials, and alkaline additions. 
Caruccio et al. (1988) reported that acid mine drainage and acid rock drainage were affected by the flow path of groundwater or any other water which might infiltrate into spoils and the unique geochemistry. Meek (1991) examined the aforementioned techniques and determined the effectiveness of each process at preventing acid mine drainage. Through the collection of core samples, an acid-base account can be determined. Meek recommended that the maximum spacing between core samples be

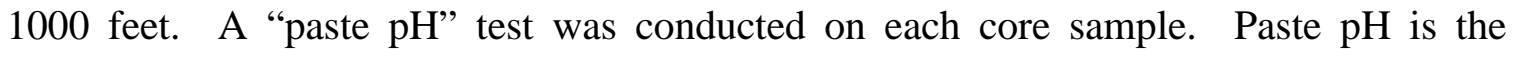
measure of pyretic salts, which is similar to the amount of weathering to which each stratum has been subjected. Paste $\mathrm{pH}$ data are valuable since acidic material leaches acid until all soluble salts are depleted. Another method of acid production prediction examined by Meek was the total pyretic sulfur analysis, which was a measure of the amount of acid producing material present in the rock. Neutralization potential analysis, which entails the measurement of alkalinity or neutralizing material present, was a third prediction technique explored by Meek.

Meek also identified several acid mine drainage prevention techniques that should be employed prior to or throughout the surface mining operations. (Surface mining operations are comparable to the disturbance of pyretic soil and rock performed during roadway construction.) Selective handling and placement were recommended to minimize the disturbance of acid producing material prior to mining or blasting. The placement of such material should be made where exposure to oxygen and water can be minimized (e.g., containment in a cap with a liner, and/or application of a porous pad). Sealing the acid producing material with a cap was also recommended. PVC, covered with a layer of non-acid producing material, was forwarded as a suitable cap. Alkaline 
addition was a third method of acid mine drainage prevention reported by Meek. Such additives included limestone admixing, phosphate admixing, and quick lime addition. The additives were mixed with the acid producing backfill at calculated intervals and then capped. This method not only seals off the acidic waste from oxygen and water, but also enables a second line of defense should any water infiltrate or penetrate the cap. Meek determined that a PVC liner was the best method of containment and prevention, 70\% efficient. The PVC liner was also the least expensive and one of the easiest to install. Yew and Makowski (1989) suggested sealing the exposed mine spoils and pyretic roadway cuts from surface water infiltration with a lime and topsoil cap.

Acid base accounting (ABA) has been evaluated by many researchers for its accuracy in predicting the potential for acid mine drainage. Brady et al. (1994) accredited Sobek (1978) with creating the original version of the acid base account. The formula the $\mathrm{ABA}$ was based on Equation 2.5:

$$
\mathrm{FeS}_{2}+2 \mathrm{CaCO}_{3}+3.75 \mathrm{O}_{2}+1.5 \mathrm{H}_{2} \mathrm{O} \rightarrow \mathrm{Fe}(\mathrm{OH})_{3}+2 \mathrm{SO}_{4}^{2-}+2 \mathrm{Ca}^{2+}+2 \mathrm{CO}_{2}
$$

When iron disulfide is mixed with calcium carbonate, oxygen, and water, ferric hydroxide, sulfate, calcium, and carbon dioxide are created. The sulfate produced through this reaction is the main acid generator.

Several researchers recommend specific values for the neutralization potential (NP) to acid production potential (AP) ratio. Ferguson and Morin (1991) and Ferguson and Robertson (1994) summarized the criteria for ABA in a three category table, as presented in presented in Table 2.1. 
Table 2.1. Categories for ABA Data (Ferguson and Morin 1991, Ferguson and Robertson 1994).

\begin{tabular}{|c|c|c|}
\hline Category & NP/AP Range & Description \\
\hline Likely & NP/AP $<1$ & $\begin{array}{c}\text { likely to generate ARD unless } \\
\text { sulfide is unreactive }\end{array}$ \\
\hline Possibly & $1<$ NP/AP $<2$ & $\begin{array}{c}\text { possible ARD producer if } \\
\text { neutralizing materials are } \\
\text { depleted, coated, or } \\
\text { unreactive }\end{array}$ \\
\hline Non-Acid Generating & NP/AP $>2$ & not expected to produce ARD \\
\hline
\end{tabular}

The basis for the ABA as defined by Ferguson and Morin (1991) was a combination of an acid generation test based on a sulfur assay (determination of the percent sulfur present multiplied by 31.25 ) and a neutralization generation test based on the digestion of the acid and a titration. Based on the aforementioned analyses, the net neutralization potential (NNP; neutralization potential minus the acid generation potential) can be determined. All values used in the $\mathrm{ABA}$ are expressed in tons of $\mathrm{CaCO}_{3}$ equivalents per 1000 tons of material to be remediated. Ferguson and Morin determined that an NNP less than 5 tons of $\mathrm{CaCO}_{3}$ per 1000 tons could be considered acid generating and that an NNP greater than 20 tons of $\mathrm{CaCO}_{3}$ per 1000 tons would not be considered an AMD/ARD generating term in this reaction.

Brady et al. (1994) determined that different NNP criteria were appropriate for the acid rock drainage studied. An NNP greater than 30 tons of $\mathrm{CaCO}_{3}$ per 1000 tons was considered non-acid generating material, and an NNP less than 20 tons of $\mathrm{CaCO}_{3}$ per 1000 tons was considered an acid producer. The "gray area" between 20 and 30 tons of $\mathrm{CaCO}_{3}$ per 1000 tons was primarily alkaline producing material ( 7 out of 10 sites within this range evaluated were alkaline). 
Caruccio et al. (1988) identified the major sources of sulfur as coal, lignites, and organic-rich shales. Sulfur can occur as iron disulfide, organic sulfur, sulfate minerals, and native sulfur; however, iron disulfide and organic sulfur are the forms which are most destructive and prevalent. For surface mining and blasting, four methods exist for the determination of pyretic sulfur in a coal sample. The petrographic method is a microscopic evaluation of the percent volume of iron disulfide and a calculation of the percent weight of pyretic sulfur. In the chemical method, a dilute nitric acid is applied to extract the iron pyrite from the sample and then the sample is analyzed for iron and sulfur. The estimation method entails the application of the following relationship as presented in Equation 2.6:

$w t \% S($ pyretic $)=k * w t \% S($ total $)-L$

Where $\mathrm{k}$ is a constant generally between 0.5 and 0.9 and $\mathrm{L}$ is between 0.3 and $0.6, \mathrm{~S}$ is the total or pyretic sulfur by percent weight. The values of $\mathrm{k}$ and $\mathrm{L}$ were determined from experimental data. The fourth method is the difference method in which the organic sulfur and sulfate sulfur are subtracted from the total sulfur to determine the pyretic sulfur content.

Caruccio et al. (1988) outlined factors that influenced the iron disulfide reaction rate. The crystal structure of the iron disulfide was considered important because the structure determined the speed of the reaction rate. There are two iron disulfide crystal structures:

- pyrite, which has an isometric structure and has a slower reaction speed, and

- marcasite, which has an orthorhombic structure, greater free energy, and a faster reaction speed. 
The surface area was considered a predominant factor because as the surface area increases, the volume for surface reactions to occur increases. A third influence was temperature; the reaction rate nearly doubled with an increase of $10{ }^{\circ} \mathrm{C}$ (from $0{ }^{\circ} \mathrm{C}$ to 10 ${ }^{\circ} \mathrm{C}$. Another important factor was the oxygen concentration, which was directly related to the reaction rate. As the partial pressure of water increases, the oxidation rate increases, which in turn, increases the reaction rate. A sixth factor was the $\mathrm{pH}$. The oxidation rate was reported to increase with $\mathrm{pH}$ until a $\mathrm{pH}$ of 6.0 for abiotic conditions and 3.6 for biotic conditions. A decrease in reaction rate was observed past the designated $\mathrm{pH}$. The ferrous to ferric iron adsorption ratio and total iron concentration were additional factors that influenced the reaction rate. Pyrite is more stable when formed with ferrous as opposed to ferric, however oxidation increases until all soluble iron becomes ferric iron, then oxidation is constant.

Certain bacteria, namely Thiobacillus ferrooxidans, have also been documented as increasing the oxidation rate up to one million times compared to that of sterile waters; these bacteria thrive in acidic waters. Adsorbed impurities were a ninth influence; however, little information is available on this topic. Caruccio et al. also determined that calcium carbonate can inhibit pyrite oxidation and slow or terminate the formation of acid; however, if sufficient carbonate material was not present, only a small increase in $\mathrm{pH}$ was observed, which consequently resulted in an increase in the oxidation rate. The flushing frequency or the rate of which water was added to the pyretic material was the final factor outlined by Caruccio et al.; this factor was found to have little effect on acidity. 


\subsubsection{Mitigation and Remediation of Acid Mine Drainage and Acid Rock Drainage}

When treating acid mine drainage or waters with high metal concentrations, two major categories of treatment are employed: passive or active treatment. Active treatment methods include any system that must be operated year round with human labor, any treatment facility that reroutes the impaired water through a series of mechanical treatments, or any chemical addition that is maintained year round.

Passive treatment methods are those that are implemented then left to operate with minimal to no intervention. Through biological and chemical processes, the water is cleansed (Faulkner and Skousen 1994). Passive treatments are starting to replace the costlier active treatment processes because of lower operating costs, ease of use, and little maintenance. The six most commonly employed passive technologies for AMD/ARD treatment are presented in Figure 2.1. 


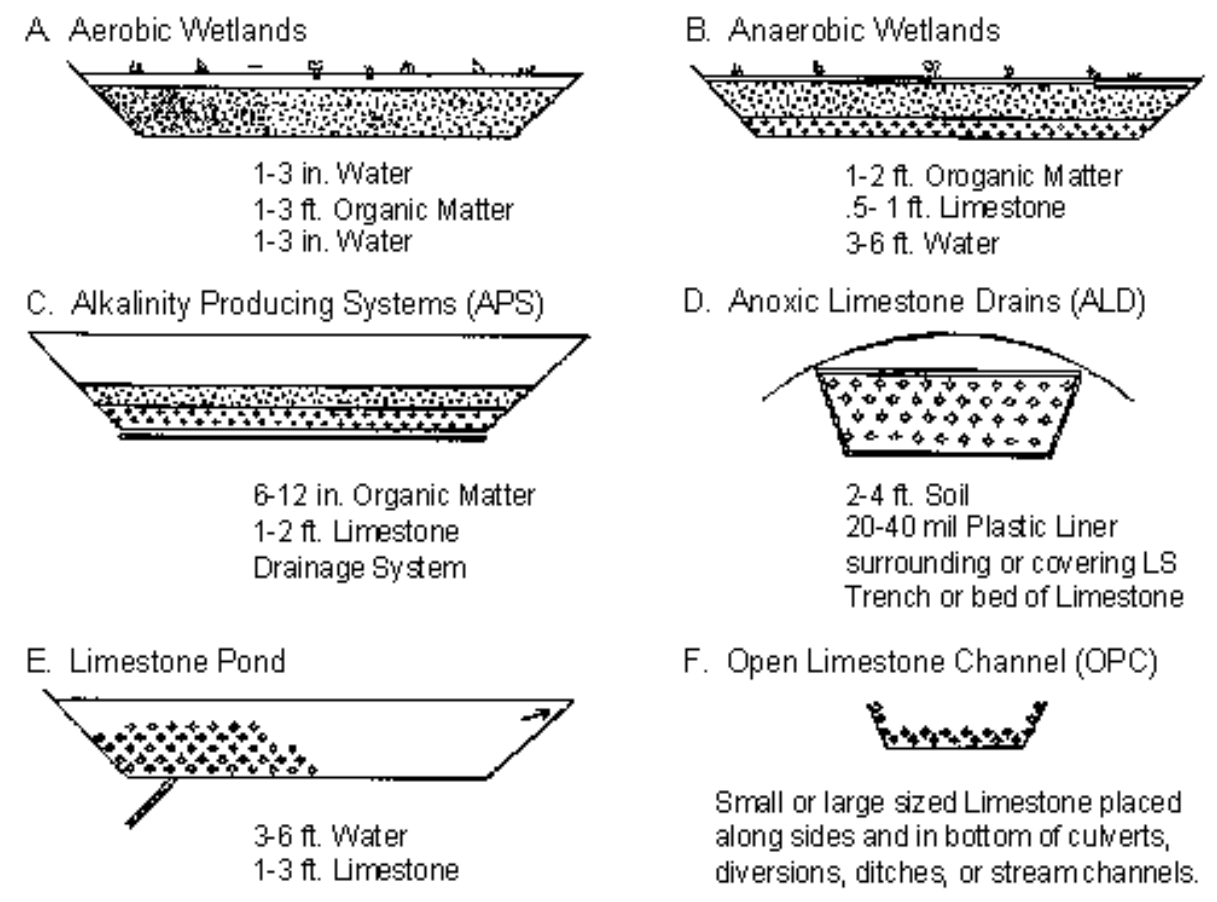

\section{Figure 2.1. Passive systems for AMD treatment (Faulkner and Skousen 1994).}

\subsection{Wetland Treatment Systems}

As early as the 1970s, natural wetlands have been used to treat acid mine drainage characterized by a low $\mathrm{pH}$ and high metal concentrations. AMD, however, degrades the quality of natural wetlands, which are protected by federal law. Constructed wetlands are not governed by this law (Faulkner and Skousen 1994). The constructed wetland was designed to replace the natural wetland.

Constructed wetlands utilize either anaerobic or aerobic vegetation. Metal uptake within the constructed wetland is performed by one of the following mechanisms: formation and precipitation of metal hydroxides; formation of insoluble metal sulfides; organic complexation reactions; and cation exchange of metals onto negatively charged 
soil sites. Other functional components of wetlands which aid in metal removal include: direct plant uptake; neutralization by carbonates; fastening to substrate soils; metal adsorption and exchange onto algae layers; and iron hydroxide formation and sulfates reduction through microbial dissimilation (Faulkner and Skousen 1994, Henrot and Wieder 1990, Wieder 1988, Wildeman et al 1993).

Constructed aerobic wetlands are shallow pools over a relatively impermeable surface of soil, clay, or mine spoils which are typically vegetated with Typha spp, a plant with high metal uptake removal potential. Water collects in the wetland pool and is retained and aerated; upon oxidation, metals are precipitated. Aerobic wetlands can reduce aluminum concentrations by $83 \%$, iron by $50 \%$ and manganese by $18 \%$. Aerobic wetlands can also increase $\mathrm{pH}$ and decrease the acidity by $43 \%$ (Faulkner and Skousen 1994).

Anaerobic wetlands are composed of vegetation, most commonly Typha spp, growing in deep, permeable sediments consisting of soil, peat, manure, other organic materials, and limestone. Treatment occurs through interactions within the organic carbon rich substrate. Metal oxidation in the anaerobic wetland takes place in the aerobic layers and through microbial reduction reactions, which also neutralize the $\mathrm{pH}$. The high BOD, produced by the organic carbon rich substrate, causes the water to become anaerobic as it passes through the wetland. The metal reducing mechanisms in the anaerobic wetland are similar to those in the aerobic wetland. Anaerobic wetlands have the potential to reduce iron concentrations $84 \%$, manganese concentrations $7 \%$, and the total suspended solids 63\% (Faulkner and Skousen 1994).

Both anaerobic and aerobic wetlands have been known to create metal- 
contaminated soils and can potentially contaminate groundwater. The sorption of metals on the substrate eventually exhausts the removal capacities (Faulkner and Skousen 1994). Further, general factors that limit the success of wetland establishment include improper grade, improper wetland species, inadequate water level, erosion, and litter deposition and accumulation (Thrasher 1983).

The substrate of a constructed wetland, aerobic or anaerobic, should be designed to suit the character of the water that the wetland will treat. Vile and Wieder (1993) examined the alkalinity production of five substrates and determined whether the alkalinity was generated by ferric reduction or sulfate reduction. The five wetland substrates consisted of Sphagnum peat with a limestone and fertilizer mix, Sphagnum peat, sawdust, straw and manure, and mushroom compost. Water quality was tested at two temperatures, $4{ }^{\circ} \mathrm{C}$ and $25^{\circ} \mathrm{C}$. No significant sulfate reduction was reported in any of the five substrates. Vile and Wieder found that the sawdust substrate exhibited a significant increase in ferrous iron concentration, which was four times greater at $25{ }^{\circ} \mathrm{C}$ than at $4{ }^{\circ} \mathrm{C}$ and that the alkalinity generation in the mushroom compost substrate was less than in the other four substrates.

Sphagnum moss has been studied for its effectiveness at removing iron from acidic waters. Sengupta (1993) stated that little knowledge has been obtained regarding the effect of low $\mathrm{pH}$ and high metal concentrations on Sphagnum spp., however, Sphagnum spp. will not live in an environment with a $\mathrm{pH}$ greater than 6 . Through research involving two species of Sphagnum, fallax and henryense, from Big Run Bog, located in Monongalia National Forest, West Virginia, it was determined that the maximum iron concentration in which the Sphagnum would grow was $100 \mathrm{mg} / \mathrm{L}$. 
Ferrous chloride $\left(\mathrm{FeCl}_{2}\right)$ was used instead of ferrous sulfate $\left(\mathrm{FeSO}_{4}\right)$ because the presence of sulfate in water negatively effects Sphagnum growth. Iron concentrations greater than $100 \mathrm{mg} / \mathrm{L}$ were too high for both species of Sphagnum to live. The reduction in growth was believed to be related to the decline in cation exchange on the cell walls of the plants. Cation exchange on plant cell walls is a major mechanism in the uptake of metals. Of the two species evaluated, Sphagnum fallax accumulated between 30 and $230 \%$ more iron than the Sphagnum henryense.

A third species of Sphagnum moss was evaluated for its ability to efficiently remove metals from acidic waters. Gerber et al. (1985) studied the capability of Sphagnum recurvum to successfully remove iron and manganese from water. The recurvum was grown in four separate troughs, with a $\mathrm{pH}$ of 4.0 or 5.5 and either manganese sulfate, ferrous sulfate, or both. Iron was $90 \%$ reduced in the trough with a $\mathrm{pH}$ of 4.0 and in the trough with a $\mathrm{pH}$ of 5.5 . However, only $65 \%$ of the iron was removed from the trough with both iron and manganese at a $\mathrm{pH}$ of 4.0. The manganese was $76 \%$ reduced in the trough with a $\mathrm{pH}$ of $5.5,45 \%$ reduced in a $\mathrm{pH}$ of 5.5 with iron present, and only $10 \%$ reduced in a $\mathrm{pH}$ of 4.0 with iron present. Gerber et al. attributed a percentage of the metal removal to the presence of oxidizing heterotrophic bacteria in the Sphagnum moss. This research conducted by Gerber et al. (1985) contradicts the findings of Sengupta (1993) regarding the presence of sulfate hindering the growth of Sphagnum spp.; however, Gerber et al. conducted their research before Sengupta completed his and further knowledge of Sphagnum moss may have been obtained during those years. 
Murawski (1994) researched the mechanisms and applications of a peat substrate in an anaerobic wetland system, a technique applied in Minnesota for the treatment of AMD/ARD and roadway runoff. The peat removal efficiency was determined by the initial $\mathrm{pH}$ of the peat (best peat $\mathrm{pH}$ ranged from 6-8 for aerobic and greater than 5 for anaerobic wetlands), wastewater flow patterns, organic content of the peat, sulfates and organics available, hydraulic conductivity, and fiber characteristics of the peat. Murawski found that a greater hydraulic conductivity and a more complex flow pattern were favorable in the peat substrate since they provided greater contact between the influent water and organic material. Also, the author recommended an organic content of the peat of more than $90 \%$. Of the three main processes which remove metals (i.e., physical, chemical, and ion exchange), Murawski reported that chemical processes were the most influential within the peat substrate. This dominance was due primarily to the short length of chemical processes and to the strong attraction, which binds the metal ions to the surface of organics. Upon evaluating the maintenance and efficiency of the peat wetlands used in Minnesota, Murawski found that the addition of cattails to the peat wetlands improved the longevity of the peat and that the peat needed to be disked routinely to enhance drainage. The peat wetland, combined with an anoxic limestone pretreatment consisting of a peat bed surrounded by limestone berms, had a metal (i.e., iron and manganese) removal efficiency of 95-99\%.

In a constructed wetland experiment conducted by Sikora et al. (1996), an anaerobic wetland cell was followed by an aerobic wetland cell, in order to determine the influence of the combination on dissolved iron and manganese concentration. The anaerobic wetland was constructed of organic matter (i.e., mushroom compost, wood 
chips, and manure), limestone, and canary grass was used as the wetland vegetation. The aerobic wetland was composed of river gravel, through which the water would flow to be aerated after being oxygen deprived from the high BOD of the anaerobic zone. A disadvantage to anaerobic treatment identified by Sikora et al. was the surface flow at the water-sediment interface which limited the amount of water being exposed to the reducing conditions within the anaerobic layers. An increase in alkalinity was reported at elevated temperatures in the anaerobic wetland. Sikora et al. found that the kinetic processes from which manganese $\left(\mathrm{Mn}^{2+}\right)$ was oxidized were slower than the oxidation of iron, decreasing the removal rate of the manganese. Also, effective manganese oxidation requires a $\mathrm{pH}$ greater than 10 , which decreased the amount of manganese removed since the system $\mathrm{pH}$ was rarely increased above 6 . The presence of ferrous iron also hindered the reduction of manganese, as oxides are often utilized to remove iron instead of manganese. Wildeman et.al (1993) suggested that manganese removal in anaerobic wetlands would decline after the first two or three months. Sikora et al. (1996) reported similar results from their experiment, as manganese removal rates were $50 \%$ during the first three months, then the efficiencies declined to $10 \%$ as the wetland substrate become saturated with metals.

Liao et al. (1998) conducted a further study involving mitigation practices in Virginia. In this study, the removal efficiency of trace metals, organics, and nutrients in a wetland environment was examined. Liao et al. (1998) experimented with four bucket, batch-type, wetland systems to test pollutant removals. The buckets were filled with 12 kilograms of washed gravel which acted as the substratum. Liao et al. (1998) planted cattail (Typha latifolia), reed (Phragmites sp.), and bulrush (Scirpus) into the substratum. 
Bulrush was most effective in removing total phosphorus (62\%) and orthophosphorus (68\%). Zinc was $78 \%$ removed by the cattail, and the chemical oxygen demand was reduced by $42 \%$ using the reed. Removal efficiencies were reportedly dependent upon the detention times; for best results, a detention time greater than ten days was required (Liao et al. 1998).

Brooks (1984) recommended several factors when designing a constructed wetland. Cattails provide erosion control and aid in the settling of sediments. Several characteristics typical to wetland construction to avoid are round sedimentation basins with uniform slopes and depths, which reduce flow. A supply of Typha spp and Sphagnum spp. is needed at the site prior to construction. Also, the utilization of more naturalized, meandering systems enhances plant establishment and sheet flow, therefore increasing the contact between water and substrate. Construction of obstacles helps minimize the channelization through a wetland.

Stark et al. (1994) suggested that the substrate depth be approximately $15 \mathrm{~cm}$ of crushed limestone layered over $45 \mathrm{~cm}$ of spent mushroom compost or peat moss. By combining the limestone and the compost, an aerobic and anaerobic zone could be formed within the wetland. During ponding and slower flow rates, the water could infiltrate and be treated in both zones.

Waller et al. (1984) recommended the utilization of an unsaturated limestone to attenuate stormwater contaminants from highway runoff (i.e. lead and zinc). Anoxic limestone drains (ALD) are a third method of passive AMD. ALDs are buried trenches or ditches filled with limestone which channel water with high acidity and increase the $\mathrm{pH}$ by adding alkalinity, making the water anoxic. In these channels, the limestone does 
not coat or armor with iron hydroxide due to the low $\mathrm{pH}$ of the acidic water. ALDs have been known to fail or function poorly, especially when the $\mathrm{pH}$ is below five (Faulkner and Skousen 1994).

Sulfur-reducing bacteria (SRB) have been added to active and passive treatment methods, but primarily wetlands. Research has been conducted to evaluate the SRB metal removal efficiency in wetlands, biotrenches, and in pit and mine shaft applications (Kuyucak and St-Germain 1995). Kuyucak and St-Germain found that SRBs used in place of hydroxide precipitates had several advantages: high metal removals (e.g. copper, cadmium, zinc, lead, arsenic, mercury, nickel, and iron) at low $\mathrm{pH}$ ranges (3-6), a smaller volume and a more stable precipitate sludge. SRBs were less expensive than the standard sulfide reagents. Kuyucak and St-Germain examined the use of SRBs in situ and reported that the SRBs could be applied to open pits and mines and could easily be manipulated as a large, natural reactor. Nutrients were tested for their ability to aid the SRB activity. Those nutrients providing for the most SRB reactions included: cellulosic wastes (e.g. wood pulp, sawdust, bark, leaves, oat straw, and fuel and horticultural peat), organics (such as cattle manure, distillers' and brewers' dried grains, whey, molasses, and starch), and a lactic acid mixture. A stable substrate for a wetland supporting SRB activity was found to consist of limestone and either sand, phosphate, sulphidic rock, or woodchips. Kuyucak and St-Germain determined from this research that sulfur-reducing bacteria were most efficient in low load situations $(\mathrm{pH}>3.0$ and low metal concentrations), however, the efficiency decreased with the decrease of $\mathrm{pH}$ and increase in metal concentrations. 


\subsection{Alkaline Producing Systems}

Successive alkalinity producing systems (SAPS) are a combination of anoxic limestone drains and a bed of organic material or an anaerobic wetland (Faulkner and Skousen 1994). The organic material is employed in the SAPS to decrease the dissolved oxygen and increase the effectiveness of the ALD. In the SAPS process, acid mine water is channeled over organic compost compacted over a layer of limestone. The water infiltrates through the organic matter, flows between the limestone to receive alkalinity, and enters a series of underdrain pipes. The water travels through the pipes into an aerobic wetland where the metals are precipitated. From the aerobic wetland, the water flows into an anaerobic wetland, where the dissolved oxygen is decreased and ferric iron $\left(\mathrm{Fe}^{3+}\right)$ is reduced to ferrous iron $\left(\mathrm{Fe}^{2+}\right)$. Flushing the system can reduce clogging due to iron and aluminum precipitation (Faulkner and Skousen 1994). All experiments with SAPS have demonstrated a strong ability to significantly decrease soluble aluminum and iron concentrations, increase the $\mathrm{pH}$, and add alkalinity.

A new passive system consisting of limestone ponds involve the construction of a pond, lined with limestone, at the outlet of an AMD seep. Like the anoxic limestone drains, these ponds should not be used to treat waters impaired with dissolved iron or aluminum, as these metals tend to form an armor on the limestone, and the water should have a low dissolved oxygen concentration, as oxidation of metals produces a similar armor (Faulkner and Skousen 1994).

Similar to the limestone pond reported on by Faulkner and Skousen (1994) is the alkaline recharge pool, often applied to acidic seeps and areas of high acidity in the 
groundwater and surrounding streams. The concentrated alkaline recharge pool is constructed above the area where acidic seeps are present. As runoff (created by precipitation) and groundwater flow into the alkaline recharge pool, the alkalinity concentration is increased, generating a caustic solution. The alkaline water then flows through the acidic seep in the form of groundwater or overland flow, increasing the net $\mathrm{pH}$ of the impacted water, decreasing the acidity concentration, and returning the alkalinity levels to the initial concentration of the nonimpacted water. Nawrot et al. (1994) evaluated the performance of the alkaline recharge pools at the Peabody Will Scarlet Mine and reported removal efficiencies of $94 \%$ for acidity, $95 \%$ for total iron, and 91\% for sulfates. After examining the recharge pools on site, Nawrot et al. suggested that the recharge pool be constructed to directly address the physical, geochemical, and hydrologic factors of the site. Nawrot et al. found that for the most efficient acid removal in the recharge pools six steps should be adhered to:

- Use materials high in solubility such as calcium oxide or calcium

- Maximize the alkaline groundwater volume

- The amount of surface runoff should be decreased and the infiltration into the alkaline pool should be increased

- Apply several up-slope recharge pools for alkaline infiltration

- Construct infiltration drains to decrease the amount of time required to increase the alkalinity

- Allow for the alkaline diffusion and the transport to the recharge pool.

In an open limestone channel (OLC), alkalinity as limestone is added to the acid mine water in an open ditch lined. The main technical challenge with the application of 
the OLC is limestone armoring; however, it has been shown that channel length and gradient are factors that can be manipulated to minimize the effects of armoring. Where appropriate, OLCs can be implemented for long-term treatment. These channels can also be paired with other passive treatment methods for an efficient metal removal (Faulkner and Skousen 1994). Armored limestone, in open ditches has been criticized its lower efficiency compared to that of unarmored limestone typical in ALDs. However, armored limestone has been reported to be $90 \%$ as effective in neutralizing AMD as unarmored limestone and is thus a viable media to impart alkalinity in vegetated treatment ditches (Ziemkiewicz et al. 1997). 


\subsection{EXPERIMENTAL APPROACH}

\subsection{DESCRIPTION OF SAMPLING SITES}

Study sites were chosen in order to obtain water quality data, benthic macro invertebrate, and fish population along a segment of Corridor $H$, for which an assessment of potential environmental impact could be made. Laurel Run, located in the Tygart Valley River watershed, was the sampling stream chosen for this investigation of the only constructed and operating stretch of Corridor H. Laurel Run flows parallel to Corridor H and feeds the Tygart Valley River, a major regional river.

The Laurel Run site is characterized by the following representative elements which are relevant to environmental aspects of roadway construction in West Virginia: steep slopes, large volumes of acidic waste materials, difficulty revegetating spoils piles, and the presence of sedimentation ponds used to minimize off site migration of solids during roadway construction.

The Laurel Run watershed as located in the state of West Virginia and along Corridor $H$ is presented in Figure 3.1. A schematic of Laurel Run sampling sites and vicinity, as surveyed by WVU-CEE researchers, is presented in Figure 3.2. 


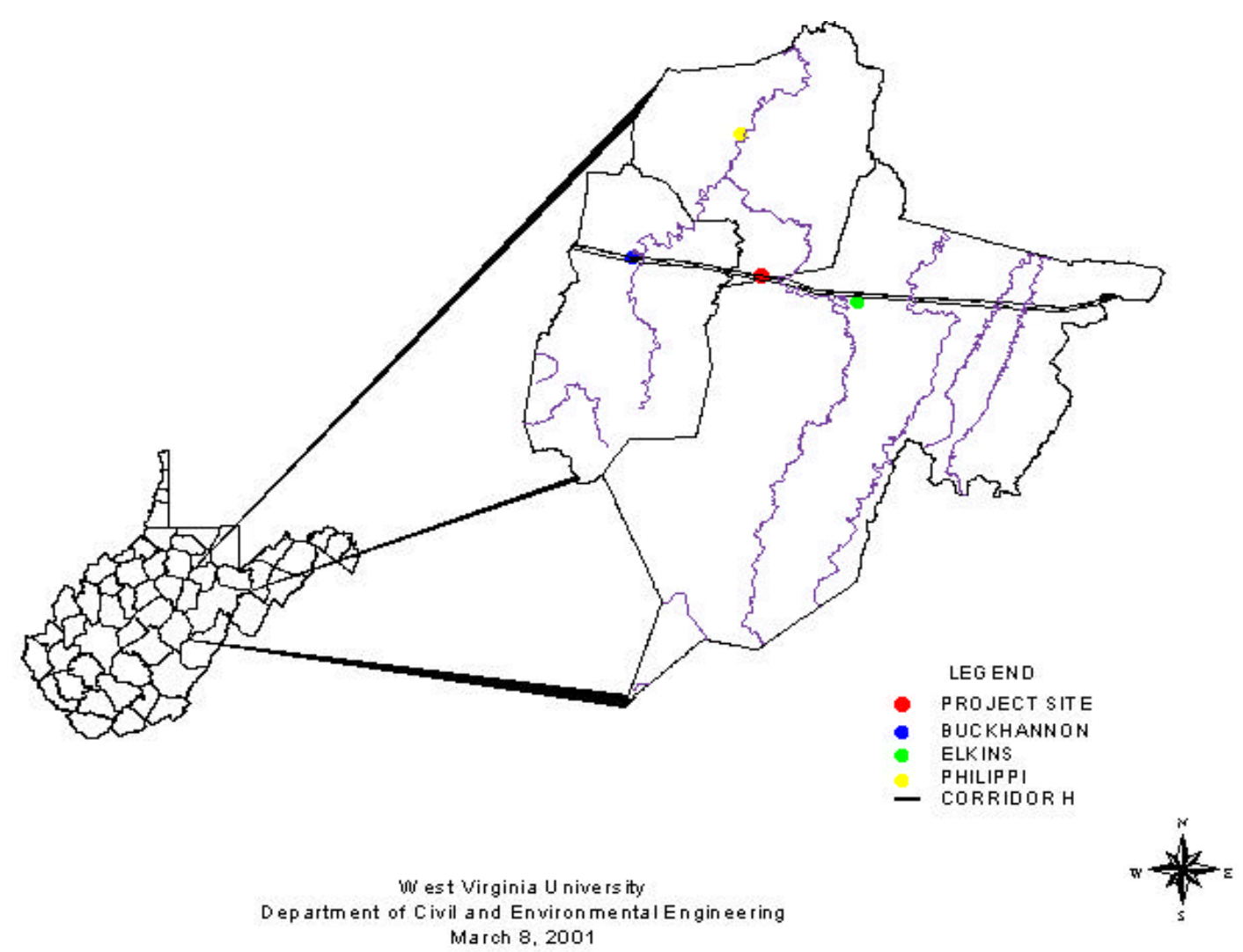

Figure 3.1. Laurel Run Watershed as located in West Virginia and along Corridor $\boldsymbol{H}$.

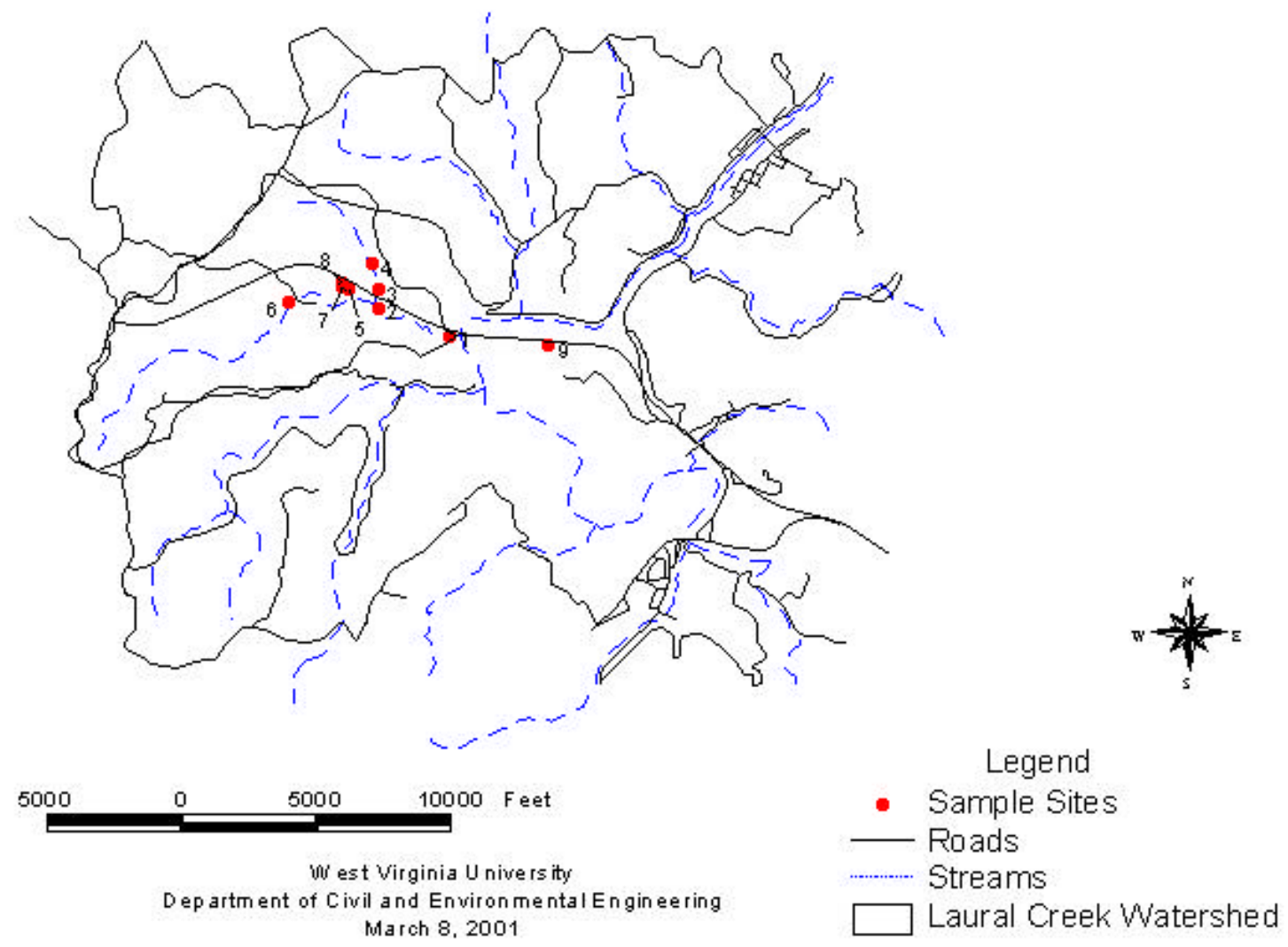

Figure 3.2. Schematic of the Laurel Run Sampling Sites and vicinity as surveyed by WVU-CEE researchers. 


\subsubsection{Lower Laurel Run}

Located at the mouth of Laurel Run, Lower Laurel Run was the first site selected for the examination of water quality. A picture of the Lower Laurel Run, Site 1, sampling station is presented in Figure 3.3, where flow is moving left to right.

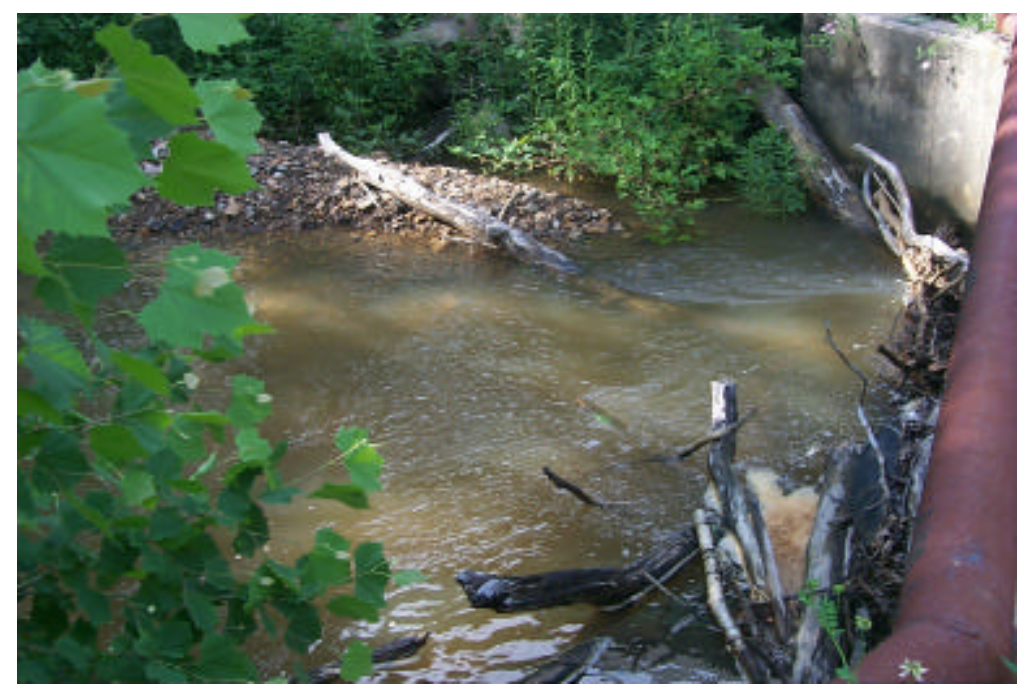

Figure 3.3. The Lower Laurel Run Sampling Station (Site 1).

Located above the last bridge prior to discharging into the Tygart Valley River, Site 1 has the potential to have high flow rates, large amounts of debris (as presented in Figure 3.3) and sediment, and high metal concentrations, due to the contributions from sources upstream of Site 1. Further, it was possible to assess the water quality from Laurel Run just prior to entering the Tygart Valley River, as net metals influx or high sediment loads will be reflected at this site. 


\subsubsection{The Box Culvert}

The second sampling site, located upstream on Laurel Run, was selected to measure the influent quality from a tributary, which flows under Corridor $H$ and an access road. A picture of the box culvert sampling station, Site 2, is presented in Figure 3.4, where flow is moving right to left.

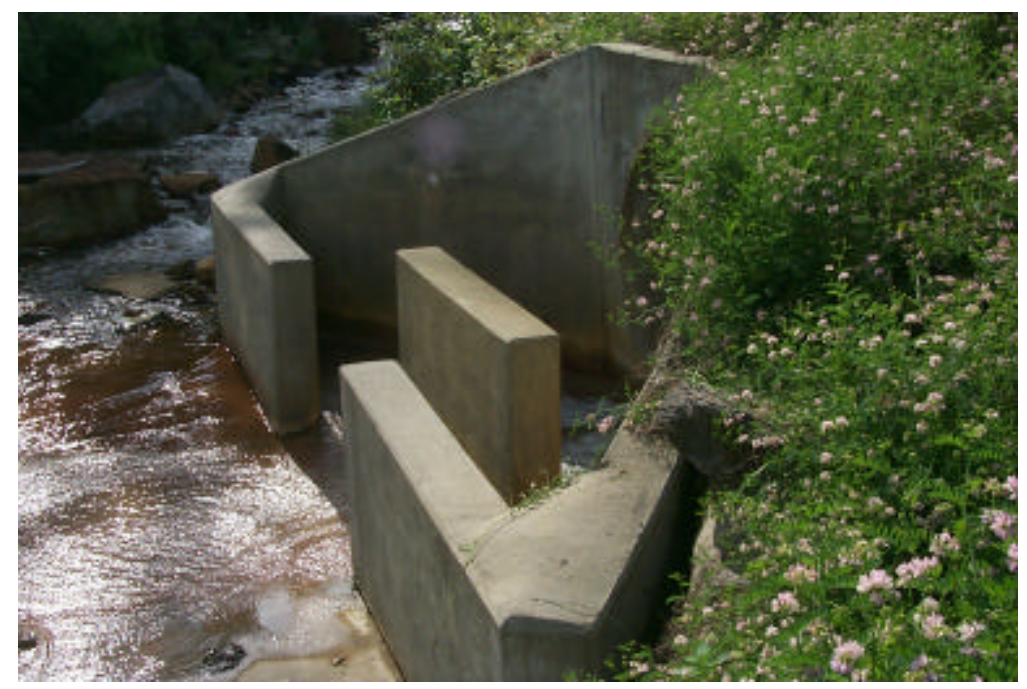

Figure 3.4. The Box Culvert Sampling Station Draining into Laurel Run (Site 2).

Site 2 had suspected high metals concentrations (e.g., iron, sulfate, and manganese) due to the orange staining on the concrete baffles and the culvert apron, and on the rocks surrounding the culvert outlet.

\subsubsection{Above the Spoils Pile}

The third sampling site, located above a spoils pile, was selected to assess the water quality prior to potential impacts of a spoils pile by comparison with the water quality data collected below the pile. A photograph of the sampling station above the 
spoils pile, Site 2a, is presented in Figure 3.5, where flow is moving from the top to the bottom of the picture.

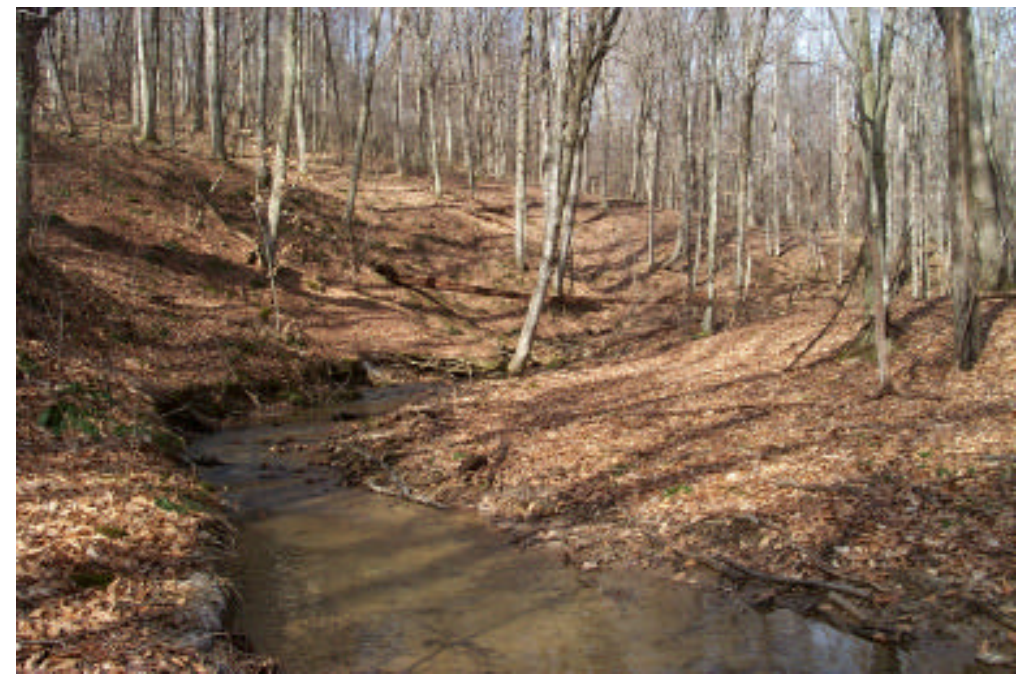

Figure 3.5. The Sampling Station Above the Spoils Pile (Site 2a).

\subsubsection{Below the Spoils Pile}

The fourth site, which was drained via the box culvert (Site 2, as presented previously), was a ditch line collecting runoff from the spoils pile. A photograph of the sampling station below the spoils pile, Site 2b, is presented in Figure 3.6, where flow is moving left to right. 


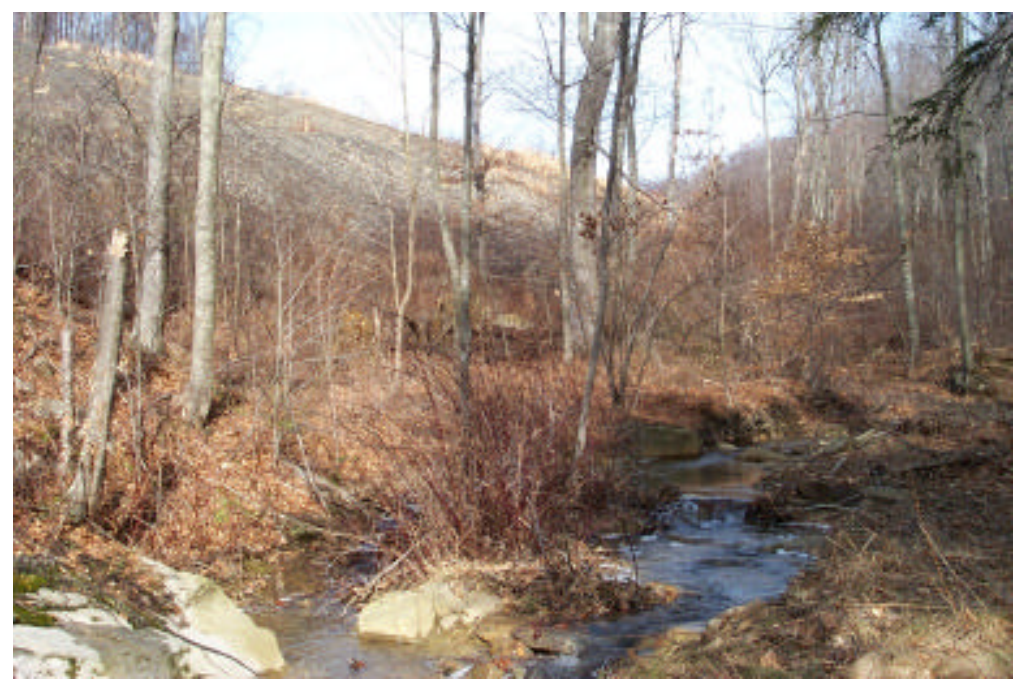

Figure 3.6. The Sampling Station Below the Spoils Pile (Site 2b).

Created during construction, the unsuitable fill was piled within a quarter of a mile from the highway (in accordance with WVDoH practices) along the alignment of the highway. An attempt to revegetate the pile was made by spreading a seed mixture of wheat, rye, and fescue, however the pile was relatively devoid of vegetation when WVUCEE researches began this study in June 2000. The sampling site was located at the base of the spoils pile, where silt and sediment build-up in the streambed were observed. This site had suspected high metal concentrations and high total suspended solids concentrations believed to have been created as a result of surface runoff from the spoils pile. The water quality below the spoils pile was established in order to determine the potential impact of the spoils pile on downstream water quality, based on a comparison with water quality data collected above the spoils pile (Site 2a). 


\subsubsection{Middle Laurel Run}

Middle Laurel Run was selected to establish water quality conditions midway up the drainage basin. A photograph of the Middle Laurel Run sampling station, Site 3, is presented in Figure 3.7, where the water is flowing from the top to the bottom of the picture.

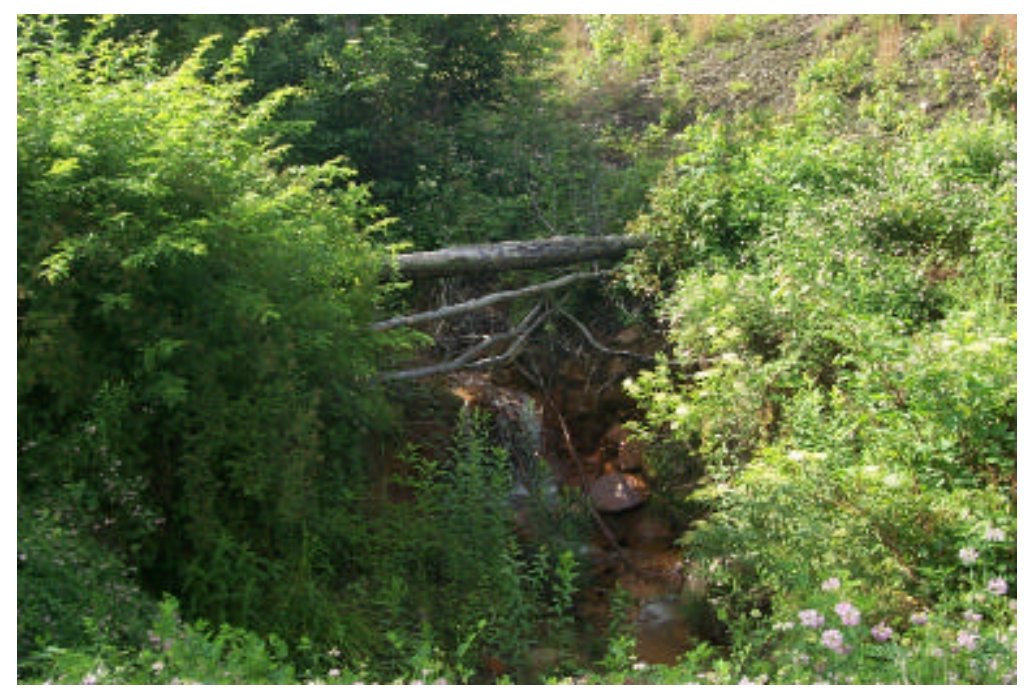

Figure 3.7. The Middle Laurel Run Sampling Station (Site 3).

At the inlet of a second culvert draining into Laurel Run, Site 3 was a steep drop into the water where samples were collected. Orange staining from the presence of iron oxides at Site 3 was an example of physical indications of water quality, which investigators observed emptying into Laurel Run, and eventually into the Tygart Valley River.

\subsubsection{Above the Sedimentation Pond}

At the inlet of a sedimentation pond, located on a tributary discharging into Laurel Run, an additional sampling site was designated. The sedimentation pond was 
constructed as a means of controlling the runoff from Corridor $H$ during construction. A photograph of the sampling station above the sedimentation pond, Site $3 \mathrm{a}$, is presented in Figure 3.8, where flow is moving right to left.

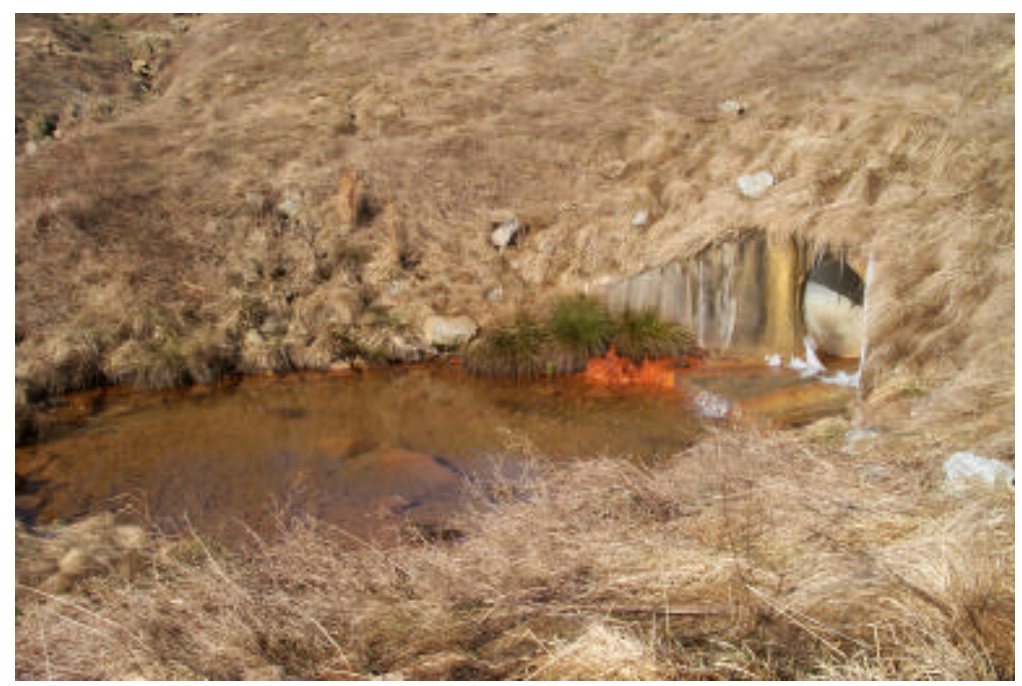

Figure 3.8. The Sampling Station Above the Sedimentation Pond (Site 3a).

The water quality data collected at Site 3 a were compared with that at the outlet of the sedimentation pond to ascertain the function of the basin. An oily sheen was frequently noticed at this site, as water washes off of Corridor $H$ and into the pond. Orange staining from iron hydroxide precipitation along with a strong "rust" odor were also present.

\subsubsection{Below the Sedimentation Pond}

A sampling site located at the outlet of a sedimentation pond was the seventh site investigated on Laurel Run. A picture of the sampling station below the sedimentation pond, Site 3b, is presented in Figure 3.9, where flow is moving right to left. 


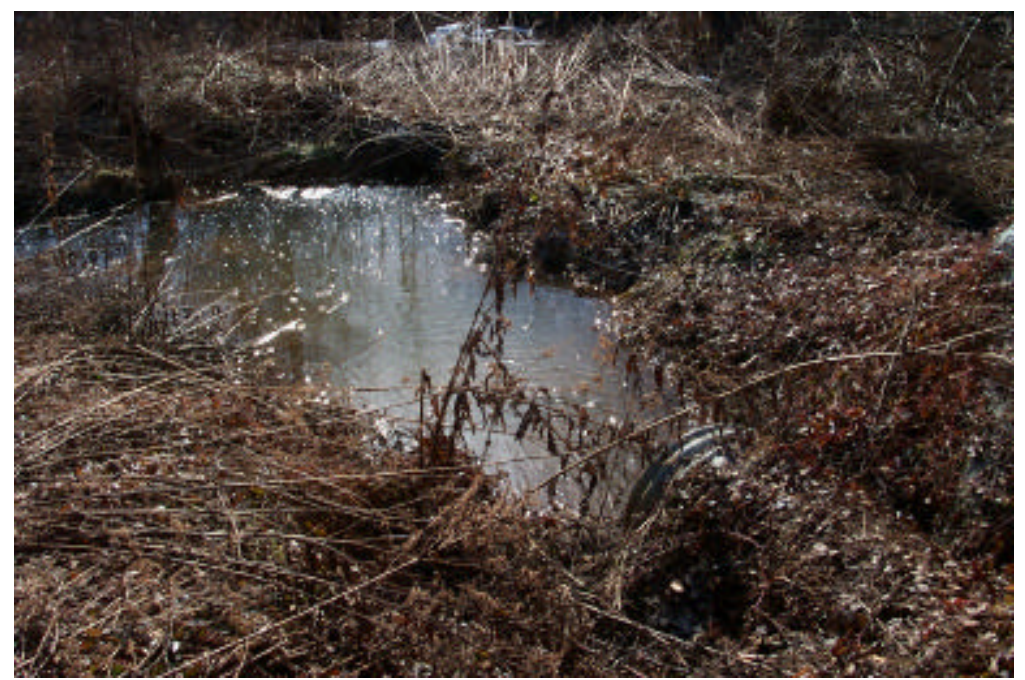

Figure 3.9. The Sampling Station Below the Sedimentation Pond (Site 3b).

Selected for its utilitarian uses, this site was compared with Site 3a in order to determine if the pond was functioning under post construction conditions.

\subsubsection{Upper Laurel Run}

The site located highest in the watershed was Upper Laurel Run, which is at the outlet of a "blown out" sedimentation pond at "Camp Seefus." A photograph of the Upper Laurel Run sampling station, Site 4, is presented in Figure 3.10, where flow is moving right to left. 


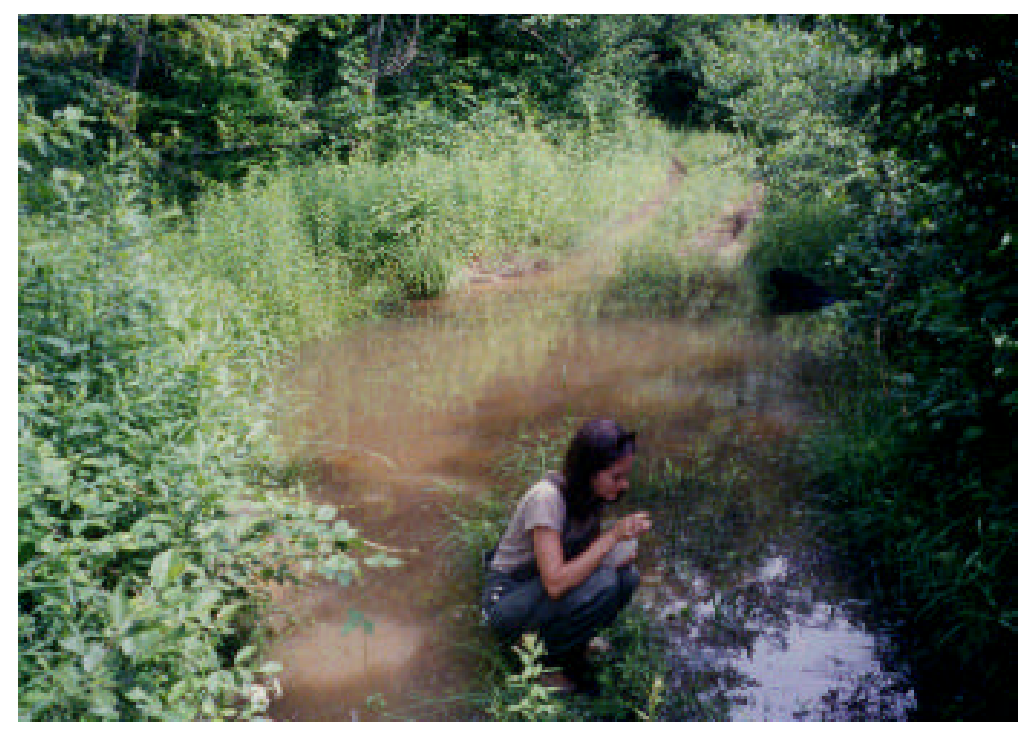

Figure 3.10. The Upper Laurel Run Sampling Station (Site 4).

Based on site observations, it was hypothesized that large amounts of sediment were carried with runoff and washout waters from the sedimentation pond and thus, contributed to downstream solids loading. The basin was believed to not be functioning as a sedimentation pond. However, the exact function of this structure was unknown.

\subsubsection{Bench Drainage}

The final site sampled in the Tygart Valley River watershed was the bench drainage. Located at the foot of an acidic seep created by a roadway cut close to an abandoned mine bench, the water quality was suspected to be poor (e.g., low $\mathrm{pH}$, high dissolved metals, etc.) A picture of the bench drainage sampling station, Site 5, is presented in Figure 3.11, where flow is moving left to right. 


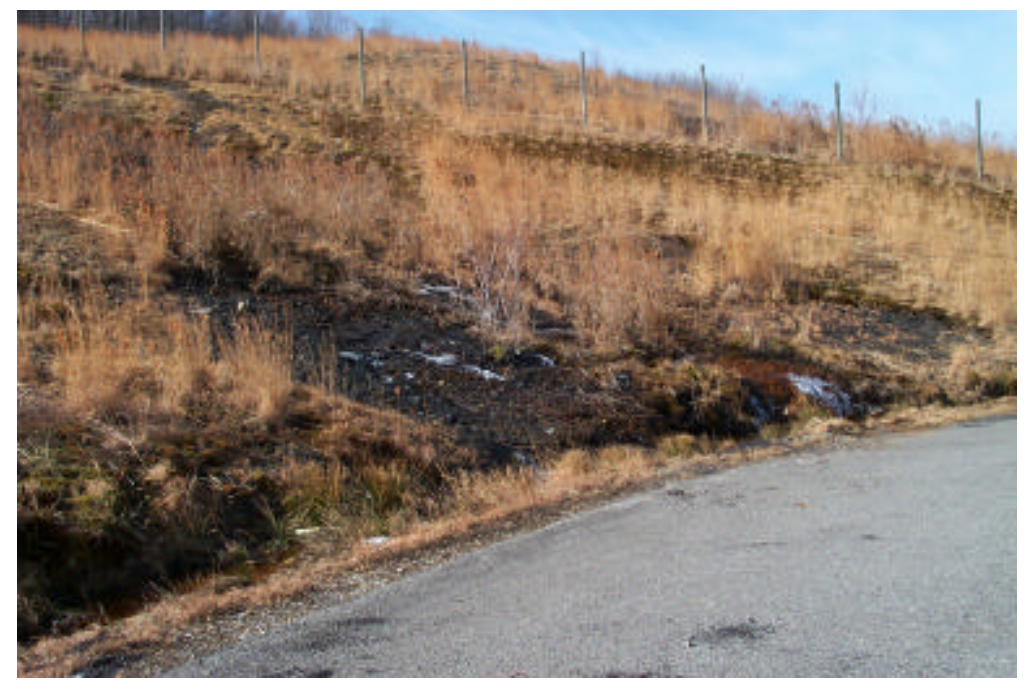

Figure 3.11. The Bench Drainage Sampling Station (Site 5).

This site was selected for examination as an example of the type of conditions that will likely be encountered in future construction projects, as the likelihood of highway construction in West Virginia passing through mining impacted lands is high. It was necessary to study a site such as Site 5 in order to develop recommendations to minimize the impacts of future construction projects which may be affected by the existence of historical mining features as well as soil geochemistry common in mining regions.

\subsection{SAMPLING REGIME}

On June 19, 2000, WVU-CEE researchers made the first field reconnaissance in the Tygart Valley River watershed, along a tributary running parallel to Corridor $H$ known as Laurel Run. The purpose of the initial trip was to collect a limited number of grab samples as "feelers," enabling WVU-CEE researchers to obtain a general perspective of the area and its water quality conditions. Samples were collected at the following sites on June 19, 2000: Site 1, Lower Laurel Run, Site 2 at the box culvert, Site 
3, Middle Laurel Run, Site 4, Upper Laurel Run, and Site 5 along the bench drainage. These were the sites which seemed most potentially detrimental on initial investigation. Upon analyzing the grab samples, researchers determined that a broader study of the area would be necessary to pinpoint the major influences on water quality.

On June 25, 2000, additional samples were collected at Sites 1 through 4, and at Site $2 \mathrm{a}$ and $2 \mathrm{~b}$, and $3 \mathrm{a}$ and $3 \mathrm{~b}$, above and below the spoils pile, and above and below the sedimentation pond, respectively. However, a complete laboratory work-up was not performed on these samples, as an insufficient volume of sample was collected to obtain meaningful results for all analytic parameters. This set of samples was used to determine whether the additional sites should be considered in future sampling. A WV Division of the Environmental Protection (DEP) certified laboratory (National Research Center for Coal and Energy, NRCCE) performed an additional examination of metal concentrations (e.g., manganese, aluminum, and magnesium.) Based on this assessment, it was decided that evaluation of the additional sites would provide a greater understanding of the sources of impaired water quality of Laurel Run. Initially, samples were collected monthly, in order to establish baseline data. The sampling was scheduled within a week of the one-month mark in order to allow for the completion of other fieldwork. After three months of obtaining samples from each of the nine sites identified in June, the time between sampling was increased to six weeks.

During the month of November 2000, a sampling of benthic macro invertebrates and fish was conducted. When present, fish were netted and stored in a bucket with stream water until they could be placed in a fish tank for observation. Macro invertebrates were collected from the water (free floating) and the underside of stones in 
the stream. A screen was employed to capture the soil, debris, and macro invertebrates loosened from the streambed. The macro invertebrates were picked from the soil and debris, placed into a Nalgene container, and euthanasized with ethyl alcohol to be sorted and studied.

\subsection{MATERIALS}

For each water quality analysis performed in the laboratory, a separate instrument was used. The meters, manufacturers of the meters, and the use of the meters in the laboratory are presented in Table 3.1.

Table 3.1. Meters, manufacturers, and laboratory use.

\begin{tabular}{|c|c|c|c|}
\hline Company & Model Number & Item Description & Use \\
\hline Thelco & 16 & Oven & Drying solids filters \\
\hline Orion & $900 \mathrm{~A}$ & $\mathrm{pH}$ meter & $\mathrm{pH}$, alkalinity \\
\hline$H A C H$ & EC20 & pH meter & $\begin{array}{l}\text { Calcium and total } \\
\text { hardness, chlorides }\end{array}$ \\
\hline$H A C H$ & EC40 & $\mathrm{pH}$ meter & $\begin{array}{l}\text { Calcium and total } \\
\text { hardness, chlorides }\end{array}$ \\
\hline Orion & & $\mathrm{pH}$ meter & Field meter for $\mathrm{pH}$ \\
\hline Fisher Scientific & & $\mathrm{pH}$ meter & Field meter for $\mathrm{pH}$ \\
\hline Fisher Scientific & & Thermometer & $\begin{array}{l}\text { Field thermometer for } \\
\text { temperature }\end{array}$ \\
\hline$H A C H$ & $\mathrm{DR} / 2010$ & Spetrophotometer & Sulfate and iron \\
\hline$H A C H$ & CO 150 & Conductivity meter & Conductivity \\
\hline$H A C H$ & CO 150 & Conductivity meter & Conductivity \\
\hline $\begin{array}{c}\text { Denver } \\
\text { Instrument } \\
\text { Company }\end{array}$ & $100 \mathrm{~A}$ & Analytic Balance & Weighing solids \\
\hline OHAUS & B5000 & Analytic Balance & Weighing solids \\
\hline Mettler Toldeo & DL50 & Auto titrator & Acidity \\
\hline Coulter & LS 230 & $\begin{array}{l}\text { Particle Size } \\
\text { Analyzer }\end{array}$ & Particle Size \\
\hline Orion & 960 & $\begin{array}{l}\text { Autochemistry } \\
\text { System }\end{array}$ & Alkalinity titration \\
\hline Global Water & $E$ & Flow Probe & Flow Measurement \\
\hline
\end{tabular}


Prior to commencement of the water quality analyses, each field and laboratory meter was calibrated according to manufacturer's specifications using freshly prepared standard solutions.

\subsection{METHODS}

\subsubsection{Water Chemistry}

All methods used for water quality analyses were derived from Standard Methods for the Analysis of Water and Wastewater (APHA 1998), with the exception of flow determination, which was based on a USEPA Method (USEPA 1999). The methods used to determine water quality and quantity parameters are presented in Table 3.2.

Table 3.2. Methods Used to Determine the Water Quality Parameters.

\begin{tabular}{|c|c|c|}
\hline Parameter & Standard Method & Detection Limit \\
\hline pH & $4500 \mathrm{H}^{+}-\mathrm{B}$ & -- \\
\hline $\begin{array}{c}\text { Turbidity } \\
\text { (Nephelometric) }\end{array}$ & $2130 \mathrm{~B}$ & -- \\
\hline Total Suspended Solids & $2540 \mathrm{D}$ & -- \\
\hline Conductivity & $2510 \mathrm{~B}$ & -- \\
\hline Alkalinity & $2320 \mathrm{~B}$ & $\mathrm{pH}<3.7$ \\
\hline Acidity & $2310 \mathrm{~B}(4 \mathrm{~d})$ & $\mathrm{pH}>8.3$ \\
\hline $\begin{array}{c}\text { Chloride (Mecuric } \\
\text { nitrate) }\end{array}$ & $4500-\mathrm{Cl}-\mathrm{C}$ & 1.0 \\
\hline Sulfate & $4500-\mathrm{SO}_{4}-\mathrm{E}$ & $7.50 \mathrm{mg} / \mathrm{L}$ \\
\hline Iron & $3500 \mathrm{Fe}$ & $0.10 \mathrm{mg} / \mathrm{L}$ \\
\hline $\begin{array}{c}\text { Calcium and Total } \\
\text { Hardness }\end{array}$ & $\begin{array}{c}3500-\mathrm{Ca} D \\
2340 \mathrm{C}\end{array}$ & $5.00 \mathrm{mg} / \mathrm{L}$ as $\mathrm{CaCO}_{3}$ \\
\hline Nitrate & $4500-\mathrm{NO}_{3}{ }^{-} \mathrm{F}$ & $0.01 \mathrm{mg} / \mathrm{L}$ \\
\hline Nitrite & $4500-\mathrm{NO}_{2}^{-} \mathrm{B}$ & $0.01 \mathrm{mg} / \mathrm{L}$ \\
\hline Phosphate & $4500-\mathrm{P} E$ & $0.01 \mathrm{mg} / \mathrm{L}$ \\
\hline Ammonia & $4500-\mathrm{NH}_{3} \mathrm{G}$ & $0.01 \mathrm{mg} / \mathrm{L}$ \\
\hline Manganese & $3120 \mathrm{~B}$ & $0.10 \mathrm{mg} / \mathrm{L}$ \\
\hline Aluminum & $3120 \mathrm{~B}$ & $0.10 \mathrm{mg} / \mathrm{L}$ \\
\hline Magnesium & $3120 \mathrm{~B}$ & $0.10 \mathrm{mg} / \mathrm{L}$ \\
\hline Flow & 5.1 & $0.002 \mathrm{~m}^{3} / \mathrm{s}$ \\
\hline Particle Size & $2560 \mathrm{D}$ & $0.04-4000 \mu \mathrm{m}$ \\
\hline
\end{tabular}


Temperature was determined using a calibrated, traceable, thermometer. The aforementioned analyses and procedures were chosen based on a review of the literature dealing with characterization of acidic drainage (Faulkner and Skousen 1998, Meek 1991, Murawski 1994). Aside from problems associated with low $\mathrm{pH}$, acidic waters usually have significant metal concentrations (e.g., iron, aluminum, and manganese). Sulfate concentration can be detrimental as well, especially in the presence of iron (Barrett, et.al 1995a, Faulkner and Skousen 1994, and Maestri and Lord 1987).

Analytic values below detection limits will be noted in accordance with the guidelines for analyzing data with nondetects, from Guidance for Data Quality Assessment, USEPA (1998), where $<15 \%$ of the data are nondetects and it is recommended that the nondetects be replaced with one half the detection limit, the detection limit, or a very small number for statistical analysis.

Flow rate was determined using the Global Water Flow Probe, by first measuring the stream bed width. The stream width was then divided into segments according to length: less than $5 \mathrm{~m}, 5$ divisions; 5 - $10 \mathrm{~m}, 10$ sections; and more than $10 \mathrm{~m}, 15$ segments. Then the depth of the stream was measured using a meter stick at the midpoint of each division. The velocity of the stream was determined utilizing the flow probe at the same location as the depth measurement. Using the cross-section area and the velocity for each section, the flow rate for the stream could be ascertained (USEPA 1999).

Samples from each site were stored at zero headspace in plastic bottles and transported on ice. Six liters of water were collected at each site for total suspended solids analysis, particle size analysis, alkalinity, $\mathrm{pH}$, conductivity, and acidity, as well as 
for external laboratory analyses (nitrate, nitrite, phosphate, ammonia, manganese, aluminum, and magnesium.) Filtrate from the total suspended solids analysis was divided into four $500 \mathrm{~mL}$ containers, for sulfate, iron, chloride, calcium and total hardness analysis, and stored in a refrigerator at $4{ }^{0} \mathrm{C}$ for analysis of dissolved metal concentrations. Filtrate used for iron and calcium and total hardness analyses was acidified with $2 \mathrm{~mL}$ of concentrated nitric acid prior to refrigeration.

\subsubsection{Benthic Macro Invertebrate and Fish Assessment}

An investigation of benthic macro invertebrates in Laurel Run was conducted to establish a biological measure of suspected degradation of water quality. The impact of water quality on macro invertebrates and fish was established through studies of the species, size, and variety.

Five locations within the Laurel Run watershed were sampled for benthic macro invertebrates. A 400 micron D-frame kicknet was used following a modified EPA Rapid Bioassessment protocol II (USEPA 1999) for a total sample area of one-quarter square meter at each sample location. Employment of four replicate samples where feasible allowed for comparative analysis of natural variance within each sample reach. Identification and metric calculations were then completed for each sub-sample. Wet biomass and West Virginia Stream Condition Index scores (WVSCI) were determined for correlative purposes.

Benthic macro invertebrate samples were collected at Lower Laurel Run (Site 1), the box culvert (Site 2), below the spoils pile (Site $2 \mathrm{~b}$ ), above the spoils pile (Site 2a), and Middle Laurel Run (Site 3). Habitat paucity allowed for the collection of only three sub- 
samples Site $2 \mathrm{~b}$. Cementation of the substrate at Site 3 limited the sampling to a single one-quarter meter sub-sample. No samples were collected above or below the sedimentation pond (Site 3a and 3b) due to the lack of riffle habitats at these sites.

After sorting each sample, all benthic macro invertebrates were weighted using a gram scale to obtain a wet biomass. Wet weights were valuable for intra-study comparisons but variations in dehydration rates severely limited these data for inter-study comparisons. Any mass value recorded as less than $0.1 \mathrm{~g}$ was rounded to the scale sensitivity limit of $0.1 \mathrm{~g}$. The metric and index values were calculated on a 100 individual sub-sample, provided 100 individuals could be collected. The West Virginia Stream Condition Index (WVSCI) was chosen for data analysis since it was designed based on West Virginia benthic macro invertebrates samples (USEPA 2000). The metrics presented in the WVSCI are classified and presented in Table 3.3. 
Table 3.3. Classification of WVSCI Metrics (USEPA 2000).

\begin{tabular}{|c|c|c|}
\hline $\begin{array}{c}\text { Category } \\
\text { Specific } \\
\text { Metrics }\end{array}$ & Definition & $\begin{array}{c}\text { Expected } \\
\text { Response to } \\
\text { Degradation } \\
\text { (increase or } \\
\text { decrease) }\end{array}$ \\
\hline $\begin{array}{c}\text { Total } \\
\text { Individuals }\end{array}$ & Total benthic macro invertebrates collected in the \\
sample & decrease \\
\hline Total EPT & $\begin{array}{c}\text { Total Ephemeroptera (mayfly nymphs), } \\
\text { Plecoptera (stonefly naiads), and Trichoptera } \\
\text { (caddisfly larvae) }\end{array}$ & decrease \\
\hline$\%$ EPT & $\begin{array}{c}\text { Percent of sample comprised of Ephemeroptera } \\
\text { (mayfly nymphs), Plecoptera (stonefly naiads), } \\
\text { and Trichoptera (caddisfly larvae) }\end{array}$ & decrease \\
\hline$\%$ CHIRO & $\begin{array}{c}\text { Percent of sample comprised of } \text { chironomid } \\
\text { (midge) larvae pupae }\end{array}$ & increase \\
\hline$\% 2$ DOM & $\begin{array}{c}\text { Percent of sample comprised of the 2 most } \\
\text { abundant species }\end{array}$ & increase \\
\hline HBI & $\begin{array}{c}\text { Hilsenhoff Biotic Index, abundance-weighted } \\
\text { average tolerance of assemblage of organisms }\end{array}$ & increase \\
\hline$\%$ Filterers & $\begin{array}{c}\text { Percent abundance of individuals belonging to the } \\
\text { "filterers" }\end{array}$ & increase \\
\hline$\%$ Shredders & $\begin{array}{c}\text { Percent abundance of individuals belonging to the } \\
\text { "shredders" }\end{array}$ & decrease \\
\hline
\end{tabular}

WVSCI is classified into sub-sections of water quality, based on the score of the index, as very good, good, fair, poor, or very poor water quality. The rating system for WVSCI is presented in Table 3.4.

Table 3.4. The Rating System for WVSCI (USEPA 2000).

\begin{tabular}{|c|c|}
\hline WVSCI Score & Rating System of Water Quality \\
\hline $78-100$ & Very Good \\
\hline $70-77$ & Good \\
\hline $45-69$ & Fair \\
\hline $23-44$ & Poor \\
\hline $0-22$ & Very Poor \\
\hline
\end{tabular}




\subsection{QUALITY ASSURANCE AND QUALITY CONTROL}

WVU-CEE researchers established and implemented a quality assurance and quality control (QA/QC) program to ensure the production of defensible data. The QA/QC protocol consisted of triplicate sampling (on at least ten percent of all samples) and analytical recoveries (on at least ten percent of all samples) on each parameter, with the exception of total suspended solids and particle size analysis. Triplicates were collected for total suspended solids analysis, however analytical recoveries could not be calculated, as the solids collected on the filter during filtration can not be duplicated in a standard solution. Triplicate samples were taken at one randomly selected site each trip.

Recoveries were calculated and determined using standard solutions, following the procedure in Standard Methods for the Examination of Water and Wastewater (APHA 1998), and were reported as a "percent error". The equation used to determine the percent error in recovery is presented in Equation 3.1.

$$
\% \text { Error Recovery }=100 *\left|\frac{C_{\text {theo }}-C_{\text {recov }}}{C_{\text {theo }}}\right|
$$

where the \% error recovery is the percent error in the recovery, the theoretical concentration is the concentration calculated according to Equation 3.2, and the recovered concentration is the analytical value determined after the standard addition was made. The equation used to calculate the theoretical concentration, based on a mass balance, is presented in Equation 3.2.

$$
C_{\text {theo }}=\frac{\left(C_{\text {meas }} * V_{\text {sample }}\right)+\left(C_{\text {spike }} * V_{\text {spike }}\right)}{V_{\text {spike }}+V_{\text {sample }}}
$$

where the total volume is the volume of spike plus the volume of sample. The percent difference within the triplicates and the percent error of recovery should be below ten 
percent to be considered acceptable for inclusion in the data reduction process. The percent error in recovery for each site and analytic procedure is presented in Table 3.5.

Table 3.5. Percent Error in Recovery for Each Site and Analytic Procedure.

\begin{tabular}{|c|c|c|c|c|c|c|c|c|c|c|c|c|}
\hline \multirow{3}{*}{$\begin{array}{c}\text { Parameter } \\
\text { Site \# } \\
\end{array}$} & \multicolumn{12}{|c|}{ Percent Error, \% } \\
\hline & \multirow{2}{*}{$\begin{array}{c}6 / 19 / 00 \\
4 \\
\end{array}$} & \multirow{2}{*}{$\begin{array}{c}6 / 25 / 00 \\
2 \\
\end{array}$} & \multicolumn{2}{|c|}{$7 / 24 / 00$} & \multicolumn{2}{|c|}{$8 / 27 / 00$} & \multicolumn{2}{|c|}{$9 / 26 / 00$} & \multicolumn{2}{|c|}{\begin{tabular}{|l|}
$11 / 12 / 00$ \\
\end{tabular}} & \multicolumn{2}{|c|}{$1 / 3 / 01$} \\
\hline & & & $2 \mathbf{a}$ & 4 & 2 & $\mathbf{3 b}$ & 1 & 3 & 1 & $\mathbf{2 a}$ & 2 & 4 \\
\hline Alkalinity & 2.6 & 2.0 & 0.7 & 1.8 & 1.8 & 1.6 & 1.3 & 4.4 & 3.2 & 3.5 & $--^{3}$ & $--^{3}$ \\
\hline Acidity & $\begin{array}{c}10.2 \\
(9.8- \\
\text { Site } 3)^{1}\end{array}$ & 5.3 & $\begin{array}{c}20 \\
(\text { Site } \\
2)^{1}\end{array}$ & 24 & 22 & 3.5 & 21 & 9.7 & 17 & 27 & $--^{3}$ & $--^{3}$ \\
\hline Sulfat & 0. & $--^{2}$ & 0.9 & 3.2 & 4.6 & 1.3 & 5.5 & 4.6 & 3.7 & 0.8 & $--^{3}$ & $--^{3}$ \\
\hline Chloride & 4.3 & $--^{2}$ & 0.0 & 1.5 & 1.9 & 2.0 & 1.1 & 0.2 & 0.3 & 3.8 & 2.8 & 1.8 \\
\hline Iron & 0.1 & $--^{2}$ & 3.3 & 3.2 & 2.9 & 0.0 & 1.4 & 3.0 & 1.8 & 5.8 & $--^{3}$ & $--^{3}$ \\
\hline Calcium & 2.9 & $--^{2}$ & 0.2 & 0.2 & 3.0 & 0.5 & 2.6 & 1.7 & 2.5 & 4.7 & $--^{3}$ & $--^{3}$ \\
\hline $\begin{array}{c}\text { Total } \\
\text { Hardness }\end{array}$ & 0.8 & $--^{2}$ & 0.7 & 0.2 & 3.6 & 5.9 & 1.5 & 2.0 & 1.3 & 5.2 & $--^{3}$ & $--^{3}$ \\
\hline
\end{tabular}

${ }^{1}$ The number in parentheses is the percent error for an additional site or the site on which the standard addition was conducted.

${ }^{2}$ A complete laboratory work-up was not conducted on the second sampling in June as this was to determine the added effects of the sites above and below the spoils pile and above and below the sedimentation pond.

${ }^{3}$ Percent error of recovery could not be calculated on these samples as they were sent to a WV State Division of Environmental Protection certified laboratory (NRCCE) for analysis.

Recoveries for the acidity assay were often above ten percent due to the low analytical values (i.e., 1.0 to $20.0 \mathrm{mg} / \mathrm{L}$ as $\mathrm{CaCO}_{3}$ ). A detection limit for acidity determination with the autotitrator is currently being developed; however, sufficient number of samples have not been assayed for acidity to establish a clear lower detection limit. Due to the quality of water examined, some analytic interference in assays was present (APHA 1998). An interference was created between the indicator for the total hardness analysis and suspected oil and grease present in the samples taken from Site 3a, 
above the sedimentation pond. The oil and grease were hypothesized products of the highway runoff.

The percent difference between the triplicates for each site and analytic procedure is presented in Table 3.6.

Table 3.6. Percent Difference Between the Triplicates for Each Site and Analytic Procedure.

\begin{tabular}{|c|c|c|c|c|c|}
\hline \multirow{2}{*}{ Procedure } & \multicolumn{5}{|c|}{ Percent Difference, \% } \\
\cline { 2 - 6 } & $\mathbf{7 / 2 4 / 2 0 0 0}$ & $\mathbf{8 / 2 7 / 2 0 0 0}$ & $\mathbf{9 / 2 6 / 2 0 0 0}$ & $\mathbf{1 1 / 1 2 / 2 0 0 0}$ & $\mathbf{1 / 3 / 2 0 0 1}$ \\
\cline { 2 - 6 } & $\mathbf{S i t e} \mathbf{4}$ & $\mathbf{S i t e} \mathbf{3 b}$ & Site 1 & Site 1 & Site 2 \\
\hline Turbidity & 0.88 & 1.52 & 3.03 & 5.30 & 3.96 \\
\hline pH & 2.47 & 1.12 & 0.21 & 0.24 & 0.859 \\
\hline Conductivity & 2.65 & 0.67 & 3.35 & 2.37 & 0.57 \\
\hline $\begin{array}{c}\text { Total } \\
\text { Suspended } \\
\text { Solids }\end{array}$ & $1.49(1.75)^{1}$ & 2.03 & $5.05(13.5)^{1}$ & 26.0 & 5.70 \\
\hline Alkalinity & 0.54 & 0.72 & 0.37 & 5.65 & $2.77(3.74)^{1}$ \\
\hline Acidity & 6.34 & $1.11(5.16)^{1}$ & 7.03 & $2.44(1.92)^{1}$ & 0.20 \\
\hline Sulfate & 2.42 & 5.51 & 2.34 & 0.35 & 0.96 \\
\hline Chloride & 2.62 & 1.25 & 1.26 & 0.38 & 3.09 \\
\hline Iron & 3.43 & 7.90 & $4.92(0.09)^{1}$ & 8.04 & BDL \\
\hline Calcium & 0.90 & 0.57 & 0.26 & 1.43 & 1.08 \\
\hline $\begin{array}{c}\text { Total } \\
\text { Hardness }\end{array}$ & 0.91 & 7.69 & 0.20 & 1.95 & 0.62 \\
\hline Nitrate & $8.6(0.11)^{2}$ & $0.82(0.11)^{2}$ & 0.0 & 7.76 & 5.81 \\
\hline Nitrite & $\mathrm{BDL}$ & $\mathrm{BDL}$ & 0.0 & 0.0 & $\mathrm{BDL}$ \\
\hline Ammonia & $6.2(0.01)^{2}$ & 15.4 & 39.8 & 0.0 & $0.0(0.02)^{2}$ \\
\hline Phosphate & $\mathrm{BDL}$ & $\mathrm{BDL}$ & 23.6 & $0.0(0.02)^{2}$ & $\mathrm{BDL}$ \\
\hline Magnesium & 14.7 & 0.34 & 9.27 & 0.48 & 0.74 \\
\hline Manganese & $\mathrm{BDL}$ & $1.12(5.06)^{2}$ & 24.9 & 6.59 & 0.88 \\
\hline Aluminum & 0.6 & $\mathrm{BDL}$ & 0.12 & $7.28(0.1)^{2}$ & 3.95 \\
\hline
\end{tabular}

${ }^{1}$ Triplicate percent differences greater than ten percent were the result of an outlier. Outlier excluded from percent difference calculation (value of outlier is given in parenthesis.)

${ }^{2}$ Triplicate samples analyzed by an external laboratory (NRCCE) and has an outlier (value given in parenthesis). 


\subsection{STATISTICAL ANALYSES}

\subsubsection{Paired t-Test}

The performance of a statistical analysis was required in order to determine if a significant difference existed between water quality parameters for the sites sampled above and below the spoils pile, $2 \mathrm{a}$ and $2 \mathrm{~b}$, and the sites sampled above and below the sedimentation pond, $3 \mathrm{a}$ and $3 \mathrm{~b}$.

Using a paired t-test, it is possible to examine the changes which occur before and after (or above and below) an experimental intervention on the same individuals or parameters to determine whether or not a significant difference or effect exists. Examining changes as opposed to the values above and below the spoils pile or sedimentation pond eliminated differences due to individual responses and produced a more sensitive, powerful, test (Hayter 1996).

In order to determine whether or not the spoils pile and the sedimentation pond had any effect on the water quality of Laurel Run, the paired t-test was performed on the two sets of data, above and below the spoils pile (Sites 2a and 2b) and above and below the sedimentation pond (Sites 3a and 3b). The data were first tested to ascertain whether they were normally distributed. If the data were normal distributed, then the paired t-test was performed utilizing the SigmaStat software program by SPSS (1997) at a confidence level of 0.95 and $\alpha=0.05$. The confidence interval is an interval that contains possible values for the average or mean of a set of data. An $\alpha=0.05$ is an acceptable probability of incorrectly concluding that a difference exists between data before and after an experimental intervention. A P value of 0.05 is the probability of incorrectly concluding 
that there is a true difference between the data before and after a particular experimental intervention.

In the process of performing a paired t-test, one must first determined whether the data are normally distributed. Upon verifying that the data are normally distributed, a paired t-test statistic can be calculated and an interpretation of the data can be made. If the data were not normally distributed, then the paired t-test was judged to be invalid. The existence of a statistically significant change between two data sets was determined based on a difference greater than would be expected by chance (SPSS 1997.)

In SigmaStat, results of normality test and paired t-test statistics are reported at a $\mathrm{P}$ value of 0.05 . The paired t-test statistic was computed by determining the difference between values before and after an experimental intervention. A mean difference is then calculated, and divided by the standard error of the mean, as presented in Equation 3.3:

$$
t=\frac{\mu_{\text {difference }}}{\text { stderror } r_{\mu}}
$$

where $t$ is the paired t-test statistic, $\mu_{\text {difference }}$ is the mean difference between the above and below values, and std error $_{\mu}$ is the standard error of the mean. The value of the t-test statistic is indicative of whether or not a statistically significant relationship exists. If the absolute value of the t-test statistic is greater than two, it is concluded that a statistically significant relationship exists. However, if the absolute value of the t-test statistic is less than two, it is concluded that a statically significant relationship does not exist between the above and below data sets (i.e., difference may be due to chance) (SPSS 1997). 


\subsubsection{One-Way Analysis of Variance}

The performance of the analysis of variance was required to determine whether the cumulative flow rate through the drainage basin, as measured at Site 1, had a significant influence on the value of the water quality parameters examined. Since flow rates were measured at Site 1, the analysis of variance was performed on Site 1 only. All other sites within the drainage basin had erratic flow rates which were unobtainable some months due to insufficient flow which did not fill the flow meter conduit.

Analysis of variance (ANOVA) is the examination of a set of independent variables from a set of dependent populations. A one-way ANOVA is the examination of a dependent population which is influenced by only one independent variable. The Fvalue calculated in an ANOVA provides a correlation between the dependent and the independent populations (Hayter 1996).

In order to determine the influence of the flow rate on the water quality at Site 1 a one-way ANOVA was performed on the data. The data were first tested for normal distribution and equal variance, and then the one-way ANOVA was performed utilizing SigmaStat (SPSS 1997).

The ANOVA performed by SigmaStat tests whether the data are normally distributed and of equal variance (a measure of variability about the group mean) and reports the results as "pass" or "fail" (SPSS 1997). However, ANOVA is robust and is generally insensitive to invalid assumptions (Johnson 1994, Hines and Montgomery 1980).

In SigmaStat, results of the normality test, equal variance test, and F-test statistics are reported at a $\mathrm{P}$ value of 0.05 . The $\mathrm{P}$ value is the probability of being incorrest in 
concluding that the dependent population was influenced by the independent population. In the reported results by SigmaStat, four variables are given: degrees of freedom (DF), sum of squares (SS), mean squares (MS), and the F-test statistic. Degrees of freedom are the number of groups and the sample size which affects the sensitivity of the ANOVA. Sum of squares is the measurable variability associated with each data set in the ANOVA data table. Mean squares are an estimate of the population variances. The comparison of the aforementioned variables provides an estimation of the basis of the ANOVA. The equation for the mean squares between the data sets is presented in Equation 3.4:

$$
M S_{\text {between }}=\frac{S S_{\text {between }}}{D F_{\text {between }}}
$$

where $\mathrm{MS}_{\text {between }}$ is the mean squares between the data sets, $\mathrm{SS}_{\text {between }}$ is the sum of squares between data sets, and $\mathrm{DF}_{\text {between }}$ is the degrees of freedom between the data sets. The equation for the mean squares within individual groups is presented in Equation 3.5:

$$
M S_{\text {within }}=\frac{S S_{\text {within }}}{D F_{\text {within }}}
$$

where $\mathrm{MS}_{\text {within }}$ is the mean squares within the data sets, $\mathrm{SS}_{\text {within }}$ is the sum of squares within the data sets, and $\mathrm{DF}_{\text {within }}$ is the degrees of freedom within the data sets. The Ftest statistic is the ratio of mean squares between the data sets to mean squares within the data sets, as presented in Equation 3.6:

$$
F=\frac{M S_{\text {between }}}{M S_{\text {within }}}
$$

where $\mathrm{F}$ is the F-test statistic. If $\mathrm{F}$ is approximately 1 , then the independent variable did not have a statistically significant influence on the dependent population; however, if $\mathrm{F}$ is 
large $(>>1)$, then the independent population had a statistically significant influence on the dependent population (Hayter 1996, SPSS 1997). 


\subsection{RESULTS}

Through the evaluation of the water quality parameters presented previously in Chapter 3, knowledge of water quality in the Laurel Run drainage basin could be established. A set of criteria must be met for a water body to support aquatic life. The minimum water quality criteria necessary to support aquatic life are presented in Table 4.1 (Jenkins et al. 1995.)

Table 4.1. Summary of Standard Water Quality Criteria for Freshwater Organisms (Jenkins et al. 1995).

\begin{tabular}{|c|c|}
\hline Water Quality Parameter & Criteria \\
\hline Alkalinity & $10-400 \mathrm{mg} / \mathrm{L}\left(\right.$ as $\left.\mathrm{CaCO}_{3}\right)$ \\
\hline Total Hardness & $10-400 \mathrm{mg} / \mathrm{L}\left(\right.$ as $\left.\mathrm{CaCO}_{3}\right)$ \\
\hline Iron (dissolved) & $<1.5 \mathrm{mg} / \mathrm{L}^{2}$ \\
\hline Total Suspended Solids & $<80 \mathrm{mg} / \mathrm{L}$ \\
\hline $\mathrm{pH}$ & $6.5-8.0 \mathrm{units}$ \\
\hline Sulfate & $<850 \mathrm{mg} / \mathrm{L}$ \\
\hline Conductivity & $<500 \mu \mathrm{S} / \mathrm{cm}$ \\
\hline Aluminum & $<87 \mu \mathrm{g} / \mathrm{L}^{1}$ or $<0.087 \mathrm{mg} / \mathrm{L}^{2}$ \\
\hline Chloride & $<860 \mathrm{mg} / \mathrm{L}^{1}$ or $<230 \mathrm{mg} / \mathrm{L}^{2}$ \\
\hline Nitrite (as Nitrite-N) & $<1.0 \mathrm{mg} / \mathrm{L}^{1}$ \\
\hline Manganese & $<1.0 \mathrm{mg} / \mathrm{L}$ \\
\hline
\end{tabular}

${ }^{1}$ acute exposure to the given parameter, the average concentration for one hour, which should not be exceeded more than once during a three year period.

${ }^{2}$ chronic exposure to the given parameter, the average concentration for four days, which should not be exceeded more than once during a three year period.

\subsection{SAMPLING TRIP 1, JUNE 19, 2000}

The results of the first sampling along Laurel Run are presented in Table 4.2. The fifth site sampled from the bench drainage along Corridor $\mathrm{H}$, is not included in Table 4.2. 
Table 4.2. Results of Water Quality Analyses for June 19, 2000.

\begin{tabular}{|c|c|c|c|c|}
\hline & Site 1 & Site 2 & Site 3 & Site 4 \\
\hline Air Temp $\left({ }^{\circ} \mathrm{C}\right)$ & 19.8 & 18.1 & 21.5 & 21.5 \\
\hline $\begin{array}{c}\text { Water Temp } \\
\left({ }^{\circ} \mathrm{C}\right)\end{array}$ & 19.6 & 17.1 & 20.8 & 21.0 \\
\hline $\begin{array}{c}\text { Turbidity } \\
\text { (NTU) }\end{array}$ & 26 & 30 & 27 & 7.9 \\
\hline pH & 7.46 & 4.98 & 6.95 & 7.05 \\
\hline $\begin{array}{c}\text { Conductivity } \\
(\mu \mathrm{S} / \mathrm{cm})\end{array}$ & 217.0 & 152.3 & 396.0 & 182.2 \\
\hline TSS (mg/L) & 29.8 & 38.2 & 16.3 & 9.01 \\
\hline $\begin{array}{l}\text { Alkalinity } \\
(\mathrm{mg} / \mathrm{L} \text { as } \\
\left.\mathrm{CaCO}_{3}\right)\end{array}$ & 26.01 & 11.96 & 35.72 & 33.18 \\
\hline $\begin{array}{c}\text { Acidity } \\
(\mathrm{mg} / \mathrm{L} \text { as } \\
\left.\mathrm{CaCO}_{3}\right)\end{array}$ & 2.72 & 13.0 & 13.9 & 9.55 \\
\hline Sulfate $(\mathrm{mg} / \mathrm{L})$ & 68.9 & 67.1 & 147 & 84.3 \\
\hline Iron $(\mathrm{mg} / \mathrm{L})$ & 0.12 & 0.18 & 0.11 & 0.68 \\
\hline Chloride (mg/L) & 20.0 & 4.0 & 30.5 & 20.2 \\
\hline $\begin{array}{l}\mathrm{Calcium} \\
(\mathrm{mg} / \mathrm{L} \text { as } \\
\left.\mathrm{CaCO}_{3}\right)\end{array}$ & 52.40 & 38.80 & 102.6 & 43.80 \\
\hline $\begin{array}{c}\text { Total Hardness } \\
(\mathrm{mg} / \mathrm{L} \text { as } \\
\left.\mathrm{CaCO}_{3}\right)\end{array}$ & 77.80 & 58.40 & 146.6 & 63.20 \\
\hline Nitrate $(\mathrm{mg} / \mathrm{L})$ & BDL & 0.12 & 0.10 & BDL \\
\hline Nitrite $(\mathrm{mg} / \mathrm{L})$ & BDL & BDL & BDL & BDL \\
\hline $\begin{array}{c}\text { Phosphate } \\
(\mathrm{mg} / \mathrm{L})\end{array}$ & BDL & BDL & BDL & BDL \\
\hline $\begin{array}{c}\text { Ammonia } \\
(\mathrm{mg} / \mathrm{L})\end{array}$ & 0.03 & 0.05 & 0.20 & 0.04 \\
\hline
\end{tabular}

$\mathrm{BDL}=$ below detection limit (presented previously in Table 3.2.)

\subsubsection{Site One: Lower Laurel Run, June 19, 2000}

Samples were collected from Lower Laurel Run (Site 1 as presented previously in

Figure 3.1), located above the confluence of the Tygart River and Laurel Run. Site 1 is located immediately adjacent to Corridor $H$, where the highway passes over the Tygart River. This site is potentially impacted by runoff from ditch lines and surrounding soil 
draining Corridor $H$, which could theoretically contribute to an increase in the suspended solids concentration and metals concentration. Ditch lines along this section of the highway are not well vegetated, which has the potential to further exacerbate down stream solids loading. The total suspended solids concentration at Site 1 was $29.8 \mathrm{mg} / \mathrm{L}$, well below the limit specified previously in Table 4.1, the turbidity was 26 NTU, and the $\mathrm{pH}$ was 7.46. The conductivity was $217.0 \mu \mathrm{S} / \mathrm{cm}$, below the limit specified previously in Table 4.1. Both alkalinity and acidity were within acceptable limits at $26.0 \mathrm{mg} / \mathrm{L}$ as $\mathrm{CaCO}_{3}$, and $2.72 \mathrm{mg} / \mathrm{L} \mathrm{CaCO}_{3}$, respectively. The total iron concentration was $0.12 \mathrm{mg} / \mathrm{L}$, within acceptable levels, as presented previously in Table 4.1. Sulfate and chloride concentrations were $68.9 \mathrm{mg} / \mathrm{L}$ and $20.0 \mathrm{mg} / \mathrm{L}$, respectively. The total hardness was $77.80 \mathrm{mg} / \mathrm{L}$ as $\mathrm{CaCO}_{3}$ and calcium was $52.4 \mathrm{mg} / \mathrm{L}$ as $\mathrm{CaCO}_{3}$. Nutrient analyses performed at NRCCE (nitrate, nitrite, and phosphate concentrations) were below detection limits, and the ammonia concentration was $0.03 \mathrm{mg} / \mathrm{L}$.

Particle size analysis was conducted to determine the mean particle diameter as a means to further characterize the runoff waters. Researchers have reported that metal cations have an affinity for sorption onto smaller particles, thus particle size data may be important to elucidate the potential fate of dissolved metals (Price and Yonge 1995, Xanthopoulos and Hahn 1990, Portele et al. 1982, Gupta et al. 1981c, Kobriger and Geinopolos 1984b). Further, from a treatment point of view, larger particles have a greater settling velocity and can be efficiently removed with a relatively small sedimentation pond, while a larger sedimentation pond would be required to remove smaller particles. 
The particle size spectrum for Lower Laurel Run is presented in Figure 4.1. Site 1, Lower Laurel Run, had a mean particle diameter of $45.8 \mu \mathrm{m}$.

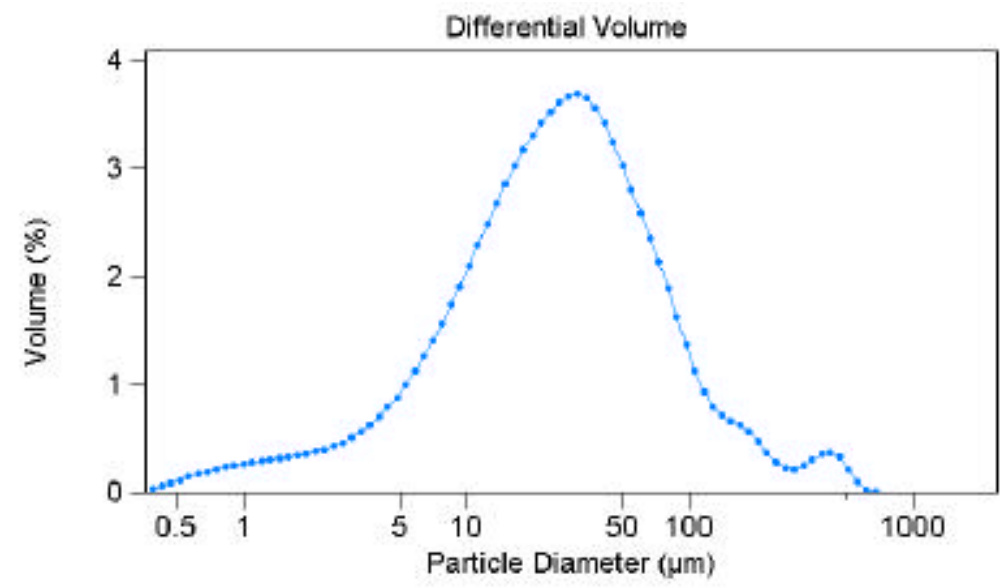

Figure 4.1. Particle Size Spectra for Lower Laurel Run (Site 1), June 19, 2000.

\subsubsection{Site Two: Box Culvert, June 19, 2000}

The second site on Laurel Run is located below a spoils pile at the outlet of a box culvert. Draining the opposite side of Corridor $H$, the box culvert passes under the highway and the adjacent gravel access road prior to entering Laurel Run. Sampling was conducted just below the culvert outlet, which traverses Corridor $H$ and the access road, collecting runoff from the opposite side and flowing into Laurel Run.

The total suspended solids concentration was $38.2 \mathrm{mg} / \mathrm{L}$ and the turbidity was 30 NTU. Iron staining was also noticed at Site 2, though the iron concentration, $0.18 \mathrm{mg} / \mathrm{L}$, was low based on criteria previously in Table 4.1. The $\mathrm{pH}$ was 4.98 and was low when compared with criteria presented previously. Conductivity was $152.3 \mu \mathrm{S} / \mathrm{cm}$. Acidity was low, $13.0 \mathrm{mg} / \mathrm{L}$ as $\mathrm{CaCO}_{3}$. The sulfate concentration was $67.1 \mathrm{mg} / \mathrm{L}$. Alkalinity was within the limits specified previously in Table 4.1 at $11.96 \mathrm{mg} / \mathrm{L}$ as $\mathrm{CaCO}_{3}$. Calcium and total hardness were $43.80 \mathrm{mg} / \mathrm{L}$ as $\mathrm{CaCO}_{3}$ and $58.40 \mathrm{mg} / \mathrm{L} \mathrm{CaCO}_{3}$, respectively. The 
chloride concentration was $4.0 \mathrm{mg} / \mathrm{L}$. Nitrate concentration was $0.12 \mathrm{mg} / \mathrm{L}$, nitrite and phosphate concentrations were below detection limits, and the ammonia concentration was $0.05 \mathrm{mg} / \mathrm{L}$, as reported by the NRCCE.

The particle size distribution for Site 2 is presented in Figure 4.2. The mean particle diameter was $39.7 \mu \mathrm{m}$.

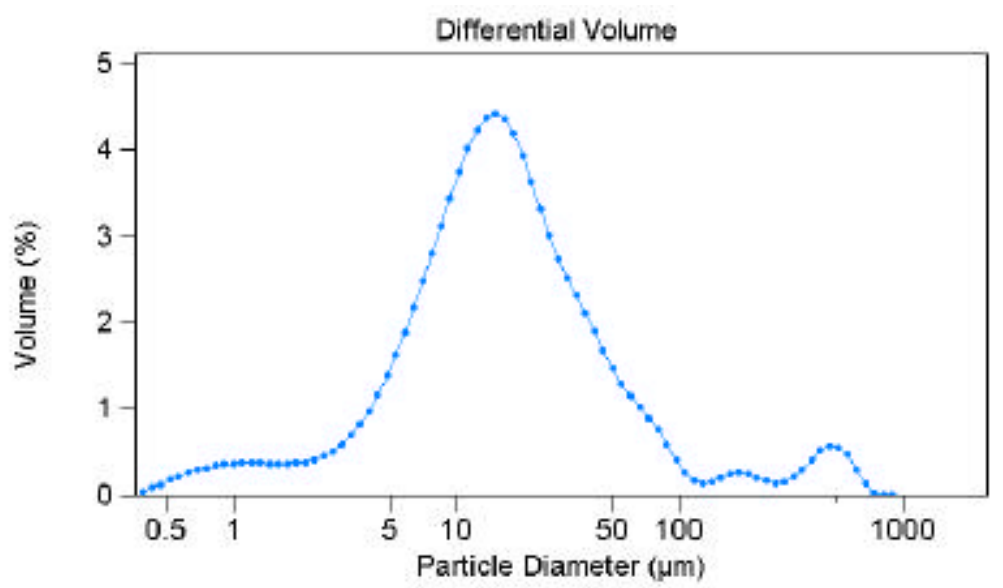

Figure 4.2. Particle Size Distribution for the Box Culvert (Site 2), June 19, 2000.

\subsubsection{Site Three: Middle Laurel Run, June 19, 2000}

Site 3 was believed to drain a second spoils pile, and investigation was required to determine the influence the pile might have on water quality. Through further investigation, a small sedimentation basin rather than a spoils pile was found to drain into Site 3. As reported in Table 4.2, the water quality parameters were within the acceptable limits: iron concentration was $0.11 \mathrm{mg} / \mathrm{L}$, sulfate concentration was $147 \mathrm{mg} / \mathrm{L}$, the $\mathrm{pH}$ was 6.95 , and both alkalinity and acidity were low, $26.0 \mathrm{mg} / \mathrm{L}$ as $\mathrm{CaCO}_{3}$ and $13.9 \mathrm{mg} / \mathrm{L}$ as $\mathrm{CaCO}_{3}$ respectively. The turbidity was 27 NTU. The total suspended solids concentration was $16.3 \mathrm{mg} / \mathrm{L}$. 
Chloride concentration was $30.5 \mathrm{mg} / \mathrm{L}$. Calcium and total hardness were 102.6 $\mathrm{mg} / \mathrm{L}$ as $\mathrm{CaCO}_{3}$ and $146.6 \mathrm{mg} / \mathrm{L}$ as $\mathrm{CaCO}_{3}$. The conductivity was $396.0 \mu \mathrm{S} / \mathrm{cm}$. Analytic results from NRCCE included a nitrate concentration of $0.10 \mathrm{mg} / \mathrm{L}$, nitrite and phosphate concentrations below detection limits, and an ammonia concentration of 0.20 $\mathrm{mg} / \mathrm{L}$. All the parameters evaluated were within the limits specified previously in Table 4.1.

As with previous sites, particle size analysis was conducted. The mean particle diameter at Site 3, Middle Laurel Run, as presented in Figure 4.3, was $13.2 \mu \mathrm{m}$.

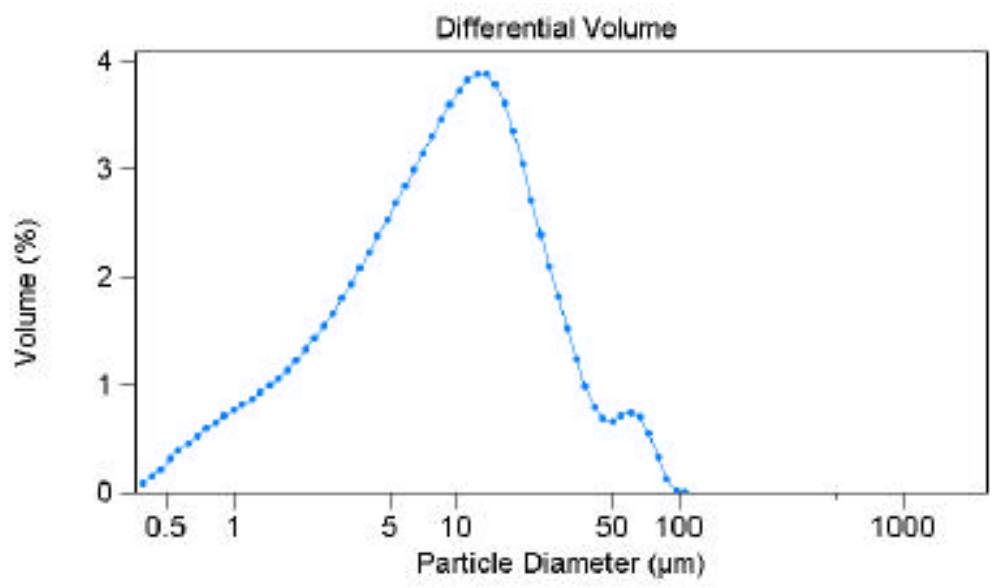

Figure 4.3. Particle Size Distribution for Middle Laurel Run (Site 3), June 19, 2000.

\subsubsection{Site Four: Upper Laurel Run, June 19, 2000}

Site four, the final site located on Laurel Run, where a sedimentation pond was constructed to reduce the runoff and solids loading from Corridor $H$; however, the lower wall of the pond receded and the water is no longer impounded. The total suspended solids concentration was $9.0 \mathrm{mg} / \mathrm{L}$, which was below the limit of $80 \mathrm{mg} / \mathrm{L}$, as specified previously in Table 4.1. Turbidity was 7.9 NTU, pH was 7.05, and conductivity was 182.2 $\mu \mathrm{S} / \mathrm{cm}$. Iron and sulfate concentrations were also within the aforementioned levels 
at $0.68 \mathrm{mg} / \mathrm{L}$ and $84.3 \mathrm{mg} / \mathrm{L}$ respectively. Alkalinity was $33.18 \mathrm{mg} / \mathrm{L}$ as $\mathrm{CaCO}_{3}$ and acidity was $9.55 \mathrm{mg} / \mathrm{L}$ as $\mathrm{CaCO}_{3}$. Calcium and total hardness were $43.80 \mathrm{mg} / \mathrm{L}$ as $\mathrm{CaCO}_{3}$ and $63.20 \mathrm{mg} / \mathrm{L}$ as $\mathrm{CaCO}_{3}$, respectively. Nitrate, nitrite, and phosphate concentrations were below detection limits, and the ammonia concentration was $0.04 \mathrm{mg} / \mathrm{L}$, as reported by the NRCCE.

Particle size analysis was attempted at Site 4; however, sufficient particle density was not present in the sample to obtain meaningful results.

\subsubsection{Site Five: Bench Drainage, June 19, 2000}

A fifth sampling site was located below an abandoned coal bench along Corridor H, on the opposite side of the Tygart Valley River from the Laurel Run sites. The site was chosen for study to assess the impact of geochemical characteristics of common acidic rock materials (e.g., coal seams and shale) on water quality. Through further investigation, it will be possible to establish the impact(s) of drainage seeps on water quality and plans can be developed to address the need for enhanced materials management practices in future construction operations. A summary of the water quality data for the bench drainage (Site 5) is presented in Table 4.3. 
Table 4.3. Water Quality Data for the Bench Drainage (Site 5), June 19, 2000.

\begin{tabular}{|c|c|}
\hline Analysis & \\
\hline Air Temperature & $23.2\left({ }^{\circ} \mathrm{C}\right)$ \\
\hline Water Temperature & $20.8\left({ }^{\circ} \mathrm{C}\right)$ \\
\hline Turbidity & 3.24 (NTU) \\
\hline $\mathrm{pH}$ & 3.22 \\
\hline Total Suspended Solids & $0.65(\mathrm{mg} / \mathrm{L})$ \\
\hline Conductivity & $477(\mu \mathrm{S} / \mathrm{cm})$ \\
\hline Alkalinity & -1 \\
\hline Acidity & $59.2\left(\mathrm{mg} / \mathrm{L}\right.$ as $\left.\mathrm{CaCO}_{3}\right)$ \\
\hline Sulfate & $179(\mathrm{mg} / \mathrm{L})$ \\
\hline Chloride & BDL \\
\hline Iron & $3.89(\mathrm{mg} / \mathrm{L})$ \\
\hline Calcium & $75.6\left(\mathrm{mg} / \mathrm{L}\right.$ as $\left.\mathrm{CaCO}_{3}\right)$ \\
\hline Total Hardness & $133\left(\mathrm{mg} / \mathrm{L}\right.$ as $\left.\mathrm{CaCO}_{3}\right)$ \\
\hline Nitrate & BDL \\
\hline Nitrite & BDL \\
\hline Ammonia & 0.01 \\
\hline Phosphate & BDL \\
\hline
\end{tabular}

${ }^{1}$ starting $\mathrm{pH}<4.3$, methyl orange indicator titrametric endpoint, therefore alkalinity could not determined.

$\mathrm{BDL}=$ below detection limit (presented previously in Table 3.2.)

The $\mathrm{pH}$ of 3.22 was below the limit specified previously in Table 4.1. The iron concentration was $3.9 \mathrm{mg} / \mathrm{L}$, which also exceeded the standard reported by Jenkins et al. (1995). With the low $\mathrm{pH}$, conditions were unsuitable for most forms of vegetation - aside from Sphagnum spp. and other forms of mosses and common algae, such as Oscillatoria or blue-green algae. At Site 5, suspended solids and high turbidity were not as great a concern as high metal concentrations. Turbidity was 3.24 NTU, total suspended solids concentration was $0.65 \mathrm{mg} / \mathrm{L}$, and conductivity was $477 \mu \mathrm{S} / \mathrm{cm}$. Alkalinity could not be determined since the starting $\mathrm{pH}$ was below 4.3, the methyl orange indicator titrametric endpoint. Acidity was $59.2 \mathrm{mg} / \mathrm{L}$ as $\mathrm{CaCO}_{3}$. Sulfate was $179 \mathrm{mg} / \mathrm{L}$. Chloride concentration was below the detection limit. Calcium and total hardness were $75.6 \mathrm{mg} / \mathrm{L}$ as $\mathrm{CaCO}_{3}$ and $133 \mathrm{mg} / \mathrm{L}$ as $\mathrm{CaCO}_{3}$, respectively. Nutrients were examined by the 
NRCCE; nitrate, nitrite, and phosphate concentrations were below detection limits, and the ammonia concentration was $0.01 \mathrm{mg} / \mathrm{L}$.

The particle size distribution was analyzed; sufficient particle density was not present in the sample to obtain meaningful results.

\subsection{SAMPLING TRIP 2, JUNE 26, 2000}

Upon evaluating the water quality data of samples collected during the initial trip to Laurel Run, several sites were added to further investigate specific water sources along Laurel Run and the mine bench drainage. Four supplementary sites were sampled in addition to the initial four located on Laurel Run to study the contribution of a spoils pile and the functioning of a sedimentation pond. Study sites above and below a spoils pile and above and below a sedimentation pond were sampled to ascertain the effects of structures and practices related to highway construction on water quality. Samples were collected on a day following a rainstorm event. Data collected after a rainstorm event were desirable for several reasons. By analyzing water laden with highway runoff and sediment, the influence of a roadway on a receiving body can be determined. The amount of dilution during a rain event can also be evaluated. Additionally, it is possible to evaluate the transport of solids under higher velocity runoff waters.

By sampling the additional sites, the most dominant water quality influences in the Laurel Run drainage basin could be determined. The additional sites, labeled 2a and $\mathrm{b}$ and $3 \mathrm{a}$ and $\mathrm{b}$ in Figure 3.1, were designated to fulfill this need. Similar water quality analyses were examined after the second sampling as performed on the initial samples; however, a sufficient amount of sample was not collected to conduct all of the previous 
analyses, as the sampling was not a regularly scheduled event. The results of the water quality analyses performed on June 26, 2000 are presented in Table 4.4.

Table 4.4. Results of Water Quality Analyses Performed on June 26, 2000.

\begin{tabular}{|c|c|c|c|c|c|c|c|c|}
\hline & Site 1 & Site 2 & Site 2a & Site $2 b$ & Site 3 & Site 3a & Site 3b & Site 4 \\
\hline $\begin{array}{c}\text { Turbidity } \\
\text { NTU }\end{array}$ & 444 & 480 & 502 & 508 & 230 & 31.9 & 187 & 19.5 \\
\hline pH & 6.99 & 6.82 & 7.50 & 6.66 & 6.89 & 7.11 & 6.73 & 7.22 \\
\hline $\begin{array}{c}\text { Conductivity } \\
(\mu \mathrm{S} / \mathrm{cm})\end{array}$ & 219 & 111 & 68.3 & 90.6 & 308 & 196 & 304 & 176 \\
\hline $\begin{array}{c}\text { TSS } \\
(\mathrm{mg} / \mathrm{L})\end{array}$ & 227 & 417 & 268 & 488 & 141 & N/A & 82.0 & N/A \\
\hline $\begin{array}{l}\text { Alkalinity } \\
(\mathrm{mg} / \mathrm{L} \text { as } \\
\left.\mathrm{CaCO}_{3}\right)\end{array}$ & 24.0 & 25.5 & 38.9 & 24.5 & 30.6 & 30.6 & 33.3 & 33.0 \\
\hline $\begin{array}{c}\text { Acidity } \\
\text { (mg/L as } \\
\text { CaCO }_{3} \text { ) }\end{array}$ & 3.34 & 4.80 & 2.42 & 5.56 & 4.92 & 3.22 & 6.82 & 2.78 \\
\hline$\underset{(\mathrm{mg} / \mathrm{L})}{\text { Manganese }}$ & 1.27 & 1.19 & 0.24 & 1.02 & 2.55 & 0.39 & 2.22 & 0.83 \\
\hline $\begin{array}{c}\text { Magnesium } \\
(\mathrm{mg} / \mathrm{L})\end{array}$ & 5.39 & 2.75 & 1.42 & 2.27 & 7.29 & 3.33 & 7.22 & 4.35 \\
\hline $\begin{array}{c}\text { Aluminum } \\
(\mathrm{mg} / \mathrm{L})\end{array}$ & 1.57 & 3.27 & 1.26 & 3.14 & 0.74 & 0.51 & 0.57 & 0.32 \\
\hline $\operatorname{Iron}(\mathrm{mg} / \mathrm{L})^{1}$ & 3.99 & 3.69 & 2.1 & 3.45 & 3.74 & 0.56 & 2.92 & 1.58 \\
\hline
\end{tabular}

N/A Not a sufficient amount of sample to obtain a meaningful result.

${ }^{1}$ usually iron analysis is performed internally, these results are from the NRCCE.

Comparing the data with the standards presented previously in Table 4.1, the water quality parameters were determined to be within the acceptable limits, with the exception of the total suspended solids concentrations, which exceeded the standard. All total suspended solids concentrations exceeded the standards for healthy aquatic life as presented previously in Table 4.1. The high sediment loading could be due in part to the rainstorm event on the previous evening. Another noticeable water quality feature was the iron concentration. All of the sites, with the exception of the site sampled above the sedimentation pond, had iron concentrations that exceed the limit for total iron identified 
previously in Table 4.1. Manganese concentrations exceeded the limit of $1.0 \mathrm{mg} / \mathrm{L}$ at all sites except for the sites above the spoils pile, above the sedimentation pond, and Upper Laurel Run.

\subsubsection{Lower Laurel Run, June 26, 2000}

Upon resampling Lower Laurel after the rain event, the turbidity and total suspended solids concentration were 444 NTU and $227 \mathrm{mg} / \mathrm{L}$ respectively. The total suspended solids concentration exceeded recommended levels presented previously in Table 4.1; however, the alkalinity and acidity were 24.0 and $3.34 \mathrm{mg} / \mathrm{L}$ as $\mathrm{CaCO}_{3}$, respectively, and were within the limits. Conductivity was $219 \mu \mathrm{S} / \mathrm{cm}$ and $\mathrm{pH}$ was 6.99 , both within the limits presented previously in Table 4.1. NRCCE performed analyses for manganese, $1.27 \mathrm{mg} / \mathrm{L}$, magnesium, $5.39 \mathrm{mg} / \mathrm{L}$, aluminum, $1.57 \mathrm{mg} / \mathrm{L}$, and iron, 3.99 mg/L. Manganese, iron, and aluminum concentrations exceeded the levels presented previously in Table 4.1 .

The mean particle size at Site 1 was $12.8 \mu \mathrm{m}$, and the particle size distribution for Lower Laurel Run is presented in Figure 4.4. 


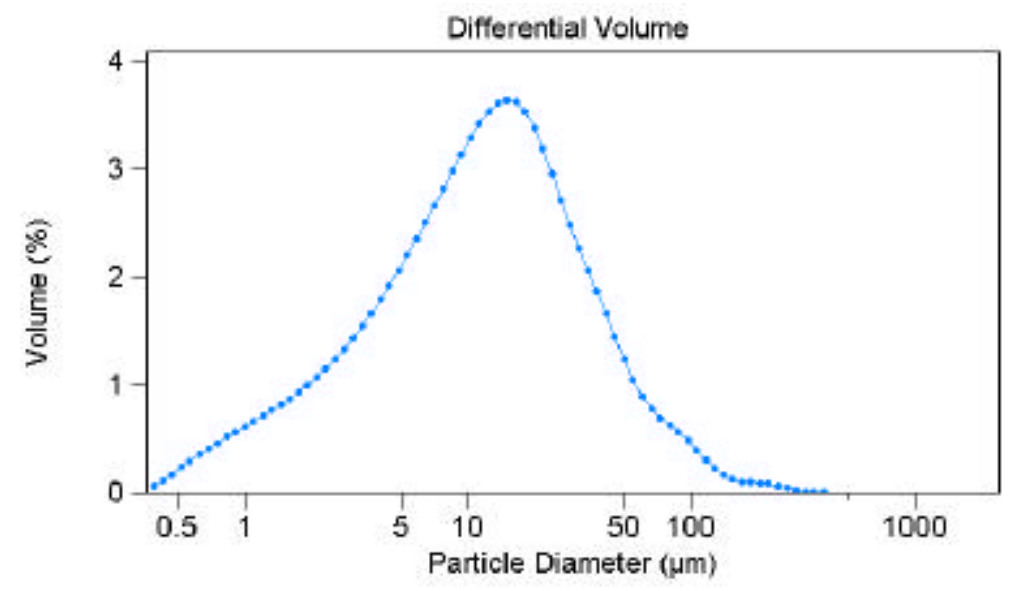

Figure 4.4. Particle Size Distribution for Lower Laurel Run (Site 1), June 26, 2000.

\subsubsection{The Box Culvert, June 26, 2000}

Site 2 (box culvert) was also sampled a second time. Turbidity and total suspended solids concentration were $480 \mathrm{NTU}$ and $417 \mathrm{mg} / \mathrm{L}$ respectively. The TSS at Site 2 exceeded the limit previously specified in Table 4.1. The $\mathrm{pH}$ was 6.82 and the alkalinity was $25.5 \mathrm{mg} / \mathrm{L}$ as $\mathrm{CaCO}_{3}$, which were within acceptable limits. Acidity was $4.80 \mathrm{mg} / \mathrm{L}$ as $\mathrm{CaCO}_{3}$. Conductivity was $111 \mu \mathrm{S} / \mathrm{cm}$, within the limit specified previously in Table 4.1. Manganese was $1.19 \mathrm{mg} / \mathrm{L}$, magnesium was $2.75 \mathrm{mg} / \mathrm{L}$, aluminum was $3.27 \mathrm{mg} / \mathrm{L}$, and iron was $3.69 \mathrm{mg} / \mathrm{L}$, as reported by NRCCE. Manganese, aluminum, and iron concentrations exceeded the limits presented previously in Table 4.1.

The particle size distribution for Site 2 is presented in Figure 4.5. The mean particle diameter was $19.1 \mu \mathrm{m}$. 


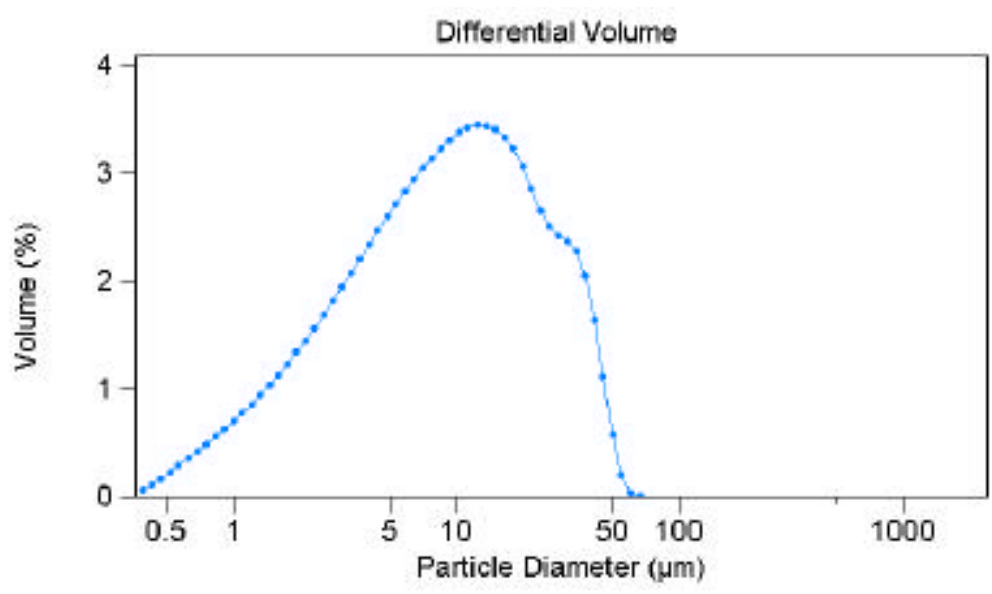

Figure 4.5. The Particle Size Distribution for the Box Culvert (Site 2), June 26, 2000.

\subsubsection{Above the Spoils Pile, June 26, 2000}

It was found that a spoils pile drained into Laurel Run via the box culvert. Therefore, additional sampling was conducted above and below the spoils pile to determine the contribution of the pile to down stream water characteristics. These two additional sites are labeled $2 \mathrm{a}$ and $2 \mathrm{~b}$ on the site map in Figure 3.1.

Site $2 \mathrm{a}$ is located above a spoils pile which drains into Laurel Run by way of a long box culvert which passes under both Corridor $H$ and the dirt access road. The data at Site $2 \mathrm{a}$ and $\mathrm{b}$ were collected after a rain event, therefore the total suspended solids concentration was $268 \mathrm{mg} / \mathrm{L}$ and turbidity was 502 NTU. The total suspended solids were above the recommended level of $80 \mathrm{mg} / \mathrm{L}$. The increased TSS was likely due to the heavy rain event, which mobilized solids from the spoils pile and adjacent sources, and thus will be reexamined. Of the other water quality parameters examined, $\mathrm{pH}$ was 7.50; conductivity was $68.3 \mu \mathrm{S} / \mathrm{cm}$, and alkalinity and acidity at $38.9 \mathrm{mg} / \mathrm{L}$ as $\mathrm{CaCO}_{3}$ and 2.42 $\mathrm{mg} / \mathrm{L}$ as $\mathrm{CaCO}_{3}$, respectively, were within acceptable levels. Manganese was $0.24 \mathrm{mg} / \mathrm{L}$, magnesium was $1.42 \mathrm{mg} / \mathrm{L}$, aluminum was $1.26 \mathrm{mg} / \mathrm{L}$, and iron was $2.1 \mathrm{mg} / \mathrm{L}$, as 
reported by the NRCCE. The aluminum and iron concentrations were above the levels specified previously in Table 4.1.

The mean particle size for the sample collected above the spoils pile was $14.8 \mu \mathrm{m}$, and the particle size distribution is presented in Figure 4.6.

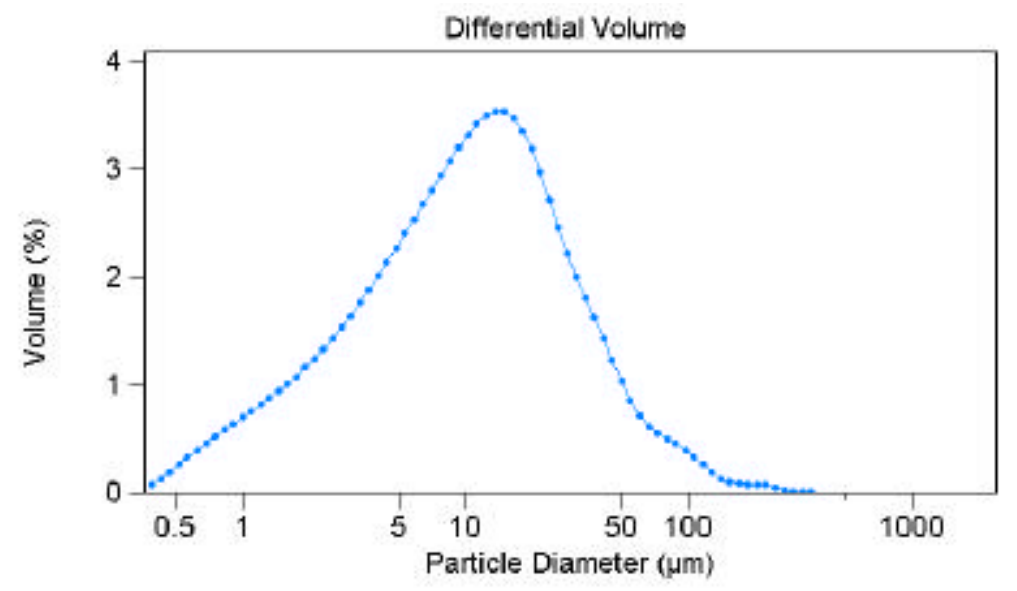

Figure 4.6. Particle Size Distribution for Site 2a, Above the Spoils Pile, June 26, 2000.

\subsubsection{Below the Spoils Pile, June 26, 2000}

At the site below the spoils pile, the total suspended solids concentration was 488 $\mathrm{mg} / \mathrm{L}$ and the turbidity was $508 \mathrm{NTU}$. The total suspended solids concentration below the spoils pile was greater than above the spoils pile due to excessive sediment loading from the soil erosion. The $\mathrm{pH}$ was 6.66 . The spoils pile was drained via Site $2 \mathrm{~b}$, where the sediment, metals, and water flowed under Corridor $H$ and into Laurel Run at Site 2. Conductivity was $90.6 \mu \mathrm{S} / \mathrm{cm}$. Alkalinity was $24.5 \mathrm{mg} / \mathrm{L}$ as $\mathrm{CaCO}_{3}$ and acidity was 5.56 $\mathrm{mg} / \mathrm{L}$ as $\mathrm{CaCO}_{3}$. Manganese was $1.02 \mathrm{mg} / \mathrm{L}$, magnesium was $2.27 \mathrm{mg} / \mathrm{L}$, aluminum was $3.14 \mathrm{mg} / \mathrm{L}$, and iron was $3.45 \mathrm{mg} / \mathrm{L}$, as reported by the NRCCE. Manganese, aluminum, and iron concentrations exceeded the limits presented previously in Table 4.1. 
The particle size distribution for Site $2 b$, below the spoils pile, is presented in Figure 4.7. The mean particle size was determined to be $17.2 \mu \mathrm{m}$.

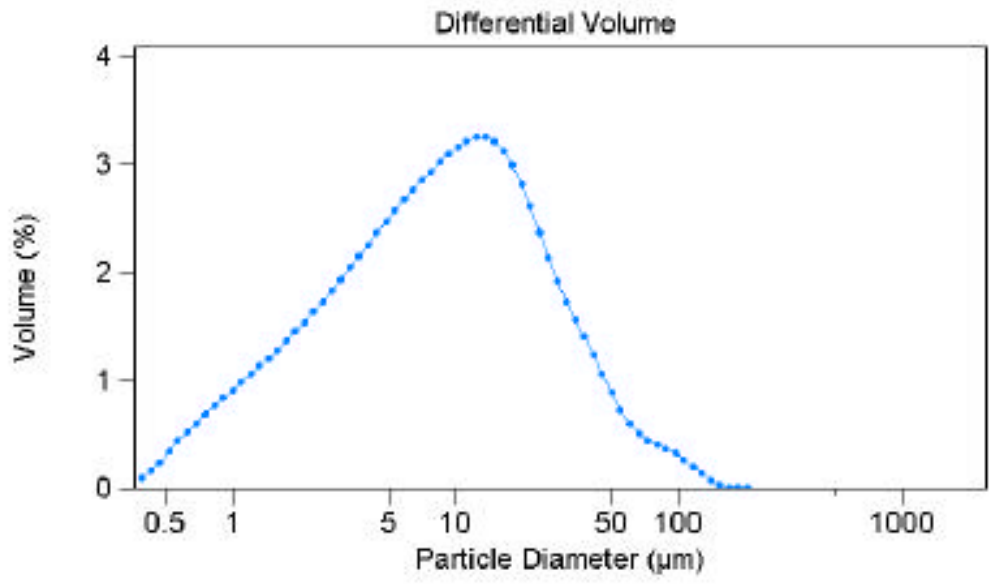

Figure 4.7. Particle Size Distribution for Site 2b, Below the Spoils Pile, June 26, 2000.

\subsubsection{Middle Laurel Run, June 26, 2000}

Likewise, a supplementary sampling was performed on Middle Laurel Run, where the total suspended solids concentration was $141 \mathrm{mg} / \mathrm{L}$, exceeding the limit previously in Table 4.1. The turbidity was 230. Alkalinity and $\mathrm{pH}$ were $30.6 \mathrm{mg} / \mathrm{L}$ as $\mathrm{CaCO}_{3}$ and 6.89 respectively, which met the standards set previously in Table 4.1. Acidity was $4.92 \mathrm{mg} / \mathrm{L}$ as $\mathrm{CaCO}_{3}$. Conductivity was $308 \mu \mathrm{S} / \mathrm{cm}$. The manganese concentration was $2.55 \mathrm{mg} / \mathrm{L}$, magnesium concentration was $7.29 \mathrm{mg} / \mathrm{L}$, aluminum concentration was $0.74 \mathrm{mg} / \mathrm{L}$, and iron concentration was $3.74 \mathrm{mg} / \mathrm{L}$ as reported by the NRCCE. Manganese, aluminum, and iron were above the allowable limits specified previously in Table 4.1. 
The particle size distribution, presented in Figure 4.8, for Middle Laurel Run (Site 3) had a mean diameter of $5.78 \mu \mathrm{m}$.

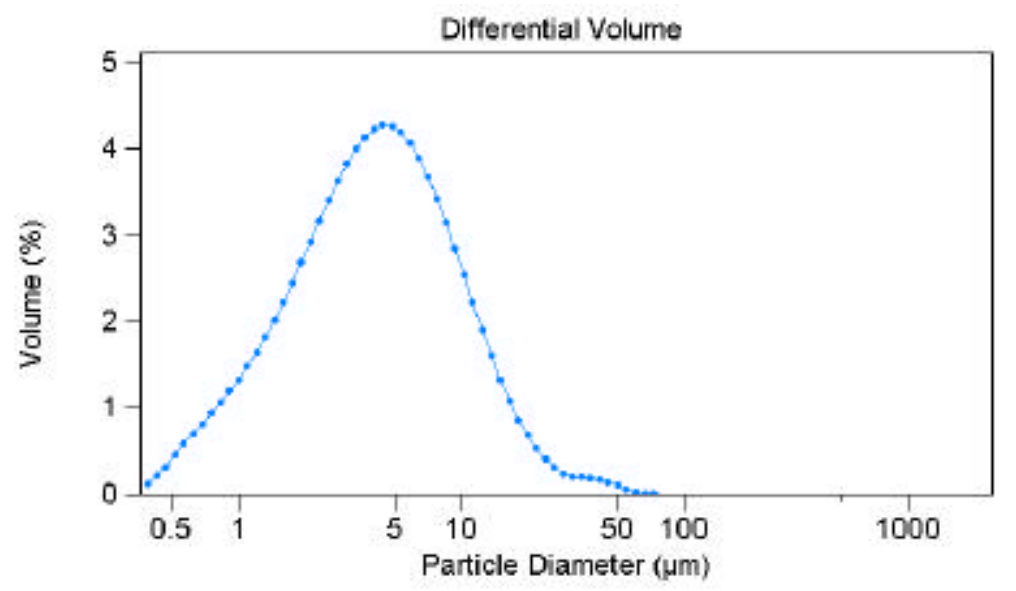

Figure 4.8. Particle Size Distribution for Middle Laurel Run (Site 3), June 26, 2000.

\subsubsection{Above the Sediment Pond, June 26, 2000}

Site 3 a was chosen to evaluate the effectiveness of the constructed sediment pond draining into Laurel Run via Site 3. The turbidity was 31.9 NTU, however, the total suspended solids were not tested due to a lack of sufficient sample volume to obtain a meaningful result. Water quality parameters evaluated were within the standards set previously in Table 4.1 with the exception of aluminum: $\mathrm{pH}$ was 7.11 , conductivity was $196 \mu \mathrm{S} / \mathrm{cm}$, acidity was $3.22 \mathrm{mg} / \mathrm{L}$ as $\mathrm{CaCO}_{3}$, and alkalinity was $30.6 \mathrm{mg} / \mathrm{L}$ as $\mathrm{CaCO}_{3}$. Manganese concentration was 0.39 , magnesium concentration was $3.33 \mathrm{mg} / \mathrm{L}$, aluminum concentration was $0.51 \mathrm{mg} / \mathrm{L}$, and iron concentration was $0.56 \mathrm{mg} / \mathrm{L}$, as reported by NRCCE.

The particle size analysis was conducted on the sampling site at the inlet of the sedimentation pond. The mean particle diameter was $14.2 \mu \mathrm{m}$. The particle size distribution for above the sedimentation pond is presented in Figure 4.9. 


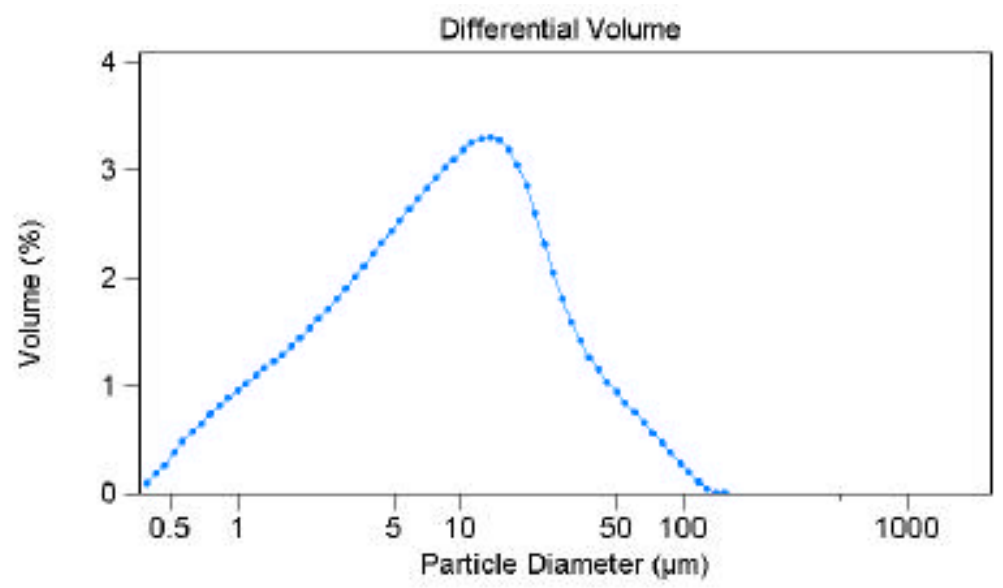

Figure 4.9. Particle Size Distribution for Above the Sedimentation Pond (Site 3a), June 26, 2000.

\subsubsection{Below the Sedimentation Pond, June 26, 2000}

The effluent of the sedimentation basin was evaluated at Site $3 \mathrm{~b}$. Four parameters were greater than the limits presented previously in Table 4.1: total suspended solids, manganese, iron, and aluminum. Turbidity was 187 NTU and total suspended solids concentration was $82.0 \mathrm{mg} / \mathrm{L}$. $\mathrm{pH}$ was 6.73 , acidity and alkalinity were $6.82 \mathrm{mg} / \mathrm{L}$ as $\mathrm{CaCO}_{3}$ and $33.3 \mathrm{mg} / \mathrm{L}$ as $\mathrm{CaCO}_{3}$, respectively. Conductivity was $304 \mu \mathrm{S} / \mathrm{cm}$. Manganese was $2.22 \mathrm{mg} / \mathrm{L}$, magnesium was $7.22 \mathrm{mg} / \mathrm{L}$, aluminum was $0.57 \mathrm{mg} / \mathrm{L}$, and iron $2.92 \mathrm{mg} / \mathrm{L}$, as reported by the NRCCE. The iron concentration, aluminum concentration, and the manganese concentration exceeded the limits set previously in Table 4.1.

Figure 4.10 is the particle size distribution for Site $3 \mathrm{~b}$ below the sedimentation pond. The mean particle diameter was $4.96 \mu \mathrm{m}$, which was indicative of the larger particles settling in the sedimentation pond and the smaller particles being carried downstream. 


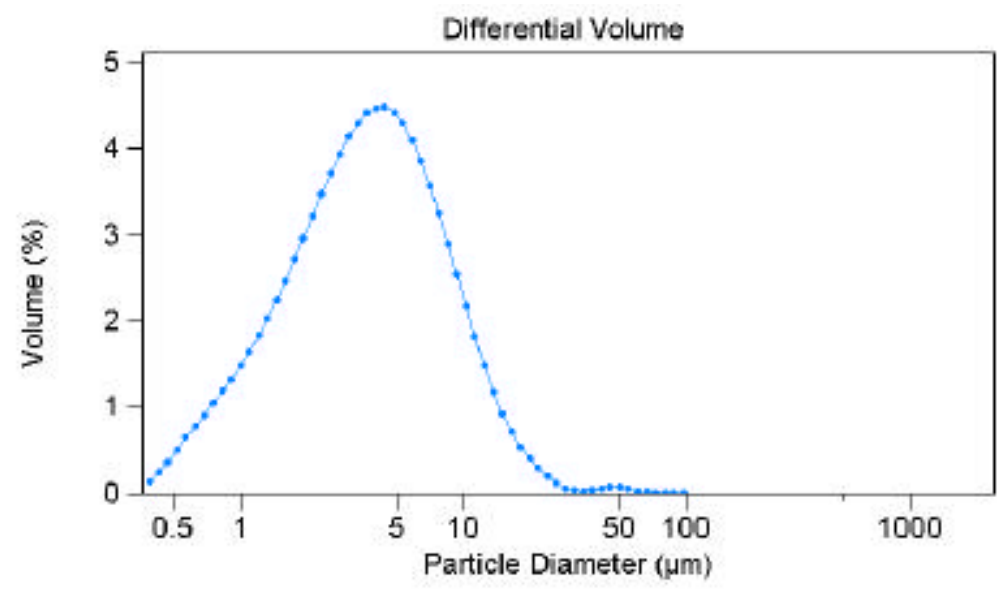

Figure 4.10. Particle Size Distribution for Below the Sediment Pond (Site 3b), June 26, 2000.

\subsubsection{Upper Laurel Run, June 26, 2000}

A supplementary sample was taken at the Upper Laurel Run site after the rain event. Aluminum and iron exceeded the limits presented previously in Table 4.1; all of the other parameters evaluated were within the limits presented previously in Table 4.1. The total suspended solids concentration could not be determined due to an insufficient sample volume. Turbidity was 19.5 NTU, $\mathrm{pH}$ was 7.22, and conductivity was 176 $\mu \mathrm{S} / \mathrm{cm}$. Alkalinity and acidity were $33.0 \mathrm{mg} / \mathrm{L}$ as $\mathrm{CaCO}_{3}$ and $2.78 \mathrm{mg} / \mathrm{L}$ as $\mathrm{CaCO}_{3}$, respectively. Manganese concentration was $0.83 \mathrm{mg} / \mathrm{L}$, magnesium concentration was $4.35 \mathrm{mg} / \mathrm{L}$, aluminum concentration was $0.32 \mathrm{mg} / \mathrm{L}$, and iron concentration was 1.58 $\mathrm{mg} / \mathrm{L}$, as reported by NRCCE.

The particle size distribution for Upper Laurel Run is presented in Figure 4.11. The water sample collected at Site 4, Upper Laurel Run, had a mean particle size of 92.3 $\mu \mathrm{m}$ after the rain event. 


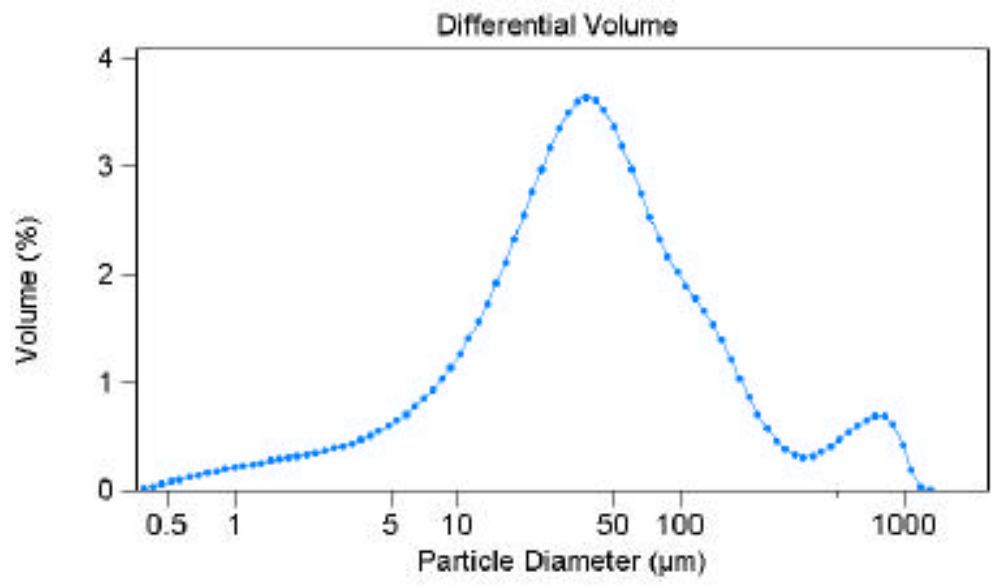

Figure 4.11. Particle Size Distribution for Upper Laurel Run (Site 4), June 26, 2000.

\subsection{SAMPLING TRIP 3, JULY 24, 2000}

After evaluating the data from the initial and supplementary samplings, continued sampling and analysis were considered beneficial. On July 24, 2000, an additional sample was taken at each site as identified previously in Figure 3.1. The results of the water quality analyses of samples collected on July 24, 2000 are presented in Table 4.5. 
Table 4.5. Water Quality Analyses for July 24, 2000.

\begin{tabular}{|c|c|c|c|c|c|c|c|c|c|}
\hline & Site 1 & Site 2 & $\begin{array}{c}\text { Site } \\
\text { 2a }\end{array}$ & $\begin{array}{c}\text { Site } \\
\text { 2b }\end{array}$ & Site 3 & Site 3a & Site 3b & Site 4 & Site 5 \\
\hline $\begin{array}{c}\text { Turbidity } \\
\text { (NTU) }\end{array}$ & 1.27 & 6.03 & 6.46 & 11.6 & 10.1 & 8.78 & 18.2 & 11.4 & 0.37 \\
\hline pH & 7.31 & 5.80 & 7.05 & 4.81 & 6.83 & 6.07 & 6.70 & 6.74 & 3.19 \\
\hline $\begin{array}{c}\text { Conductivity } \\
(\mu \mathrm{S} / \mathrm{cm})\end{array}$ & 250 & 247 & 26.2 & 186 & 582 & 831 & 549 & 178 & 698 \\
\hline TSS (mg/L) & 2.76 & 15.9 & 6.35 & 24.4 & 4.10 & 6.75 & 4.95 & 2.17 & 0.85 \\
\hline $\begin{array}{c}\text { Alkalinity } \\
(\mathrm{mg} / \mathrm{L} \text { as } \\
\left.\mathrm{CaCO}_{3}\right)\end{array}$ & 27.3 & 19.9 & 28.0 & 14.5 & 38.3 & 90.3 & 42.2 & 33.9 & $--^{1}$ \\
\hline $\begin{array}{c}\text { Acidity } \\
(\mathrm{mg} / \mathrm{L} \text { as } \\
\left.\mathrm{CaCO}_{3}\right)\end{array}$ & 3.30 & 14.8 & 3.22 & 18.7 & 7.16 & 105.5 & 9.74 & 5.13 & 69.8 \\
\hline $\begin{array}{l}\text { Sulfate } \\
\text { (mg/L) }\end{array}$ & 64.4 & 86.0 & BDL & 69.4 & 106 & 113 & 106 & 37.2 & 112 \\
\hline $\begin{array}{c}\text { Chloride } \\
\text { (mg/L) }\end{array}$ & 19.7 & 8.3 & 1.3 & 3.5 & 54.2 & 79.5 & 53.5 & 16.5 & 1.0 \\
\hline Iron $(\mathrm{mg} / \mathrm{L})$ & 0.240 & 1.10 & 0.21 & 0.35 & 0.79 & 36.1 & 0.50 & 0.62 & 5.12 \\
\hline $\begin{array}{l}\text { Calcium } \\
\text { (mg/L as } \\
\left.\mathrm{CaCO}_{3}\right)\end{array}$ & 56.2 & 73.2 & 16.2 & 52.0 & 146 & $* *$ & 149 & 38.4 & 103 \\
\hline $\begin{array}{c}\text { Total } \\
\text { Hardness } \\
(\mathrm{mg} / \mathrm{L} \text { as } \\
\left.\mathrm{CaCO}_{3}\right)\end{array}$ & 81.2 & 113 & 21.4 & 78.6 & 224 & $* *$ & 227 & 58.2 & ** \\
\hline $\begin{array}{l}\text { Nitrate } \\
(\mathrm{mg} / \mathrm{L})\end{array}$ & 0.17 & 0.17 & 0.14 & 0.18 & 0.12 & 0.02 & 0.09 & 0.09 & $\mathrm{BDL}$ \\
\hline $\begin{array}{l}\text { Nitrite } \\
\text { (mg/L) }\end{array}$ & BDL & BDL & BDL & BDL & BDL & BDL & $\mathrm{BDL}$ & BDL & $\mathrm{BDL}$ \\
\hline $\begin{array}{c}\text { Ammonia } \\
(\mathrm{mg} / \mathrm{L})\end{array}$ & 0.02 & 0.05 & BDL & 0.03 & 0.45 & 1.00 & 0.50 & 0.01 & BDL \\
\hline $\begin{array}{c}\text { Phosphate } \\
\text { (mg/L) }\end{array}$ & 0.03 & 0.02 & BDL & BDL & 0.010 & 0.01 & BDL & BDL & BDL \\
\hline $\begin{array}{c}\text { Manganese } \\
(\mathbf{m g} / \mathbf{L})\end{array}$ & 0.390 & 3.00 & BDL & 2.11 & 5.27 & 10.5 & 5.06 & 0.217 & 2.19 \\
\hline $\begin{array}{c}\text { Aluminum } \\
(\mathrm{mg} / \mathrm{L})\end{array}$ & 0.32 & 2.51 & 0.16 & 3.18 & 0.12 & 0.14 & BDL & BDL & 1.53 \\
\hline $\begin{array}{c}\text { Magnesium } \\
(\mathrm{mg} / \mathrm{L})\end{array}$ & 6.74 & 8.18 & 1.18 & 5.10 & 14.8 & 23.6 & 14.7 & 4.25 & 13.7 \\
\hline
\end{tabular}

** presence of interfering species in water sample.

${ }^{1}$ starting $\mathrm{pH}<4.3$, methyl orange indicator titrametric endpoint

$\mathrm{BDL}=$ below detection limit (presented previously in Table 3.2.) 
The results of the third sampling of Laurel Run, as presented in Table 4.5, were evaluated against the standards previously in Table 4.1. Four of the nine sites had an unsuitable $\mathrm{pH}$. Site 2, the outlet of the box culvert had a pH of 5.80 and Site 2b, below the spoils pile, which drains into Site 2, located below the spoils pile, had a $\mathrm{pH}$ of 4.81 . Site 3a, taken from the inlet of the sedimentation pond had a pH of 6.07, and Site 5, at the bench drainage had a $\mathrm{pH}$ of 3.19. Aside from low $\mathrm{pH}$, three sites had iron concentrations which exceed the levels previously specified in Table 4.1, $1.0 \mathrm{mg} / \mathrm{L}$. Site 2, at the outlet of the box culvert had an iron concentration of $1.10 \mathrm{mg} / \mathrm{L}$. Site 5 , at the bench drainage had an iron concentration of $5.12 \mathrm{mg} / \mathrm{L}$. The inlet of the sedimentation pond, Site 3a, had an iron concentration of $36.1 \mathrm{mg} / \mathrm{L}$, well above the level identified previously in Table 4.1.

Upon sampling a third time, an observation logbook was determined to be a useful tool and observations were recorded from each site. The annotations are included in the site summaries of this sampling trip. Such observations include the presence of oil or grease on the surface of the water, as observed at Site $3 \mathrm{a}$, above the sedimentation pond, and orange staining, such as those noted on the concrete box culvert at Site 2.

\subsubsection{Lower Laurel Run, July 24, 2000}

During the third sampling of Lower Laurel Run, nothing unusual was reported at the site itself. A piece of rusting metal, possibly a transmission or the internal parts of a microwave was found in the stream. As presented in Table 4.5, Site 1 is capable, from a water chemistry point of view, of supporting aquatic life. The $\mathrm{pH}$ was 7.31 , the conductivity was $250 \mu \mathrm{S} / \mathrm{cm}$, the alkalinity was $27.3 \mathrm{mg} / \mathrm{L}$ as $\mathrm{CaCO}_{3}$, and the acidity was 
$3.30 \mathrm{mg} / \mathrm{L}$ as $\mathrm{CaCO}_{3}$. The sulfate, iron, and chloride concentrations were $64.4 \mathrm{mg} / \mathrm{L}$, $0.240 \mathrm{mg} / \mathrm{L}$, and $19.7 \mathrm{mg} / \mathrm{L}$, respectively. The total suspended solids concentration was $2.76 \mathrm{mg} / \mathrm{L}$ and the turbidity was $1.27 \mathrm{NTU}$. Calcium and total hardness concentrations were $56.2 \mathrm{mg} / \mathrm{L}$ as $\mathrm{CaCO}_{3}$ and $81.2 \mathrm{mg} / \mathrm{L}$ as $\mathrm{CaCO}_{3}$, respectively. Nitrate was 0.17 $\mathrm{mg} / \mathrm{L}$, nitrite was below the detection limit, phosphate was $0.03 \mathrm{mg} / \mathrm{L}$, and ammonia was $0.02 \mathrm{mg} / \mathrm{L}$. Manganese concentration was $0.390 \mathrm{mg} / \mathrm{L}$, magnesium was $6.74 \mathrm{mg} / \mathrm{L}$, and aluminum was $0.32 \mathrm{mg} / \mathrm{L}$. The aluminum concentration exceeded the limit in Table 4.1 .

The flow was measured as $0.040 \mathrm{~m}^{3} / \mathrm{s}$. Particle size analysis was performed on this site; however the particle concentration was not large enough to detect.

\subsubsection{The Box Culvert, July 24, 2000}

Water levels at the box culvert were low and a reddish orange pyretic staining covered the concrete of the culvert and the base of the four baffles constructed to slow the water entering Laurel Run from the culvert.

At Site 2, with the exception of $\mathrm{pH}$, manganese, and aluminum, the water quality data was within the limits presented previously in Table 4.1. The $\mathrm{pH}$ was 5.80. The other parameters evaluated were within the limits, total suspended solids concentration was $15.9 \mathrm{mg} / \mathrm{L}$, the turbidity was $6.03 \mathrm{NTU}$, and the alkalinity was $19.9 \mathrm{mg} / \mathrm{L}$ as $\mathrm{CaCO}_{3}$. Sulfate and chloride concentrations were $86.0 \mathrm{mg} / \mathrm{L}$ and $8.3 \mathrm{mg} / \mathrm{L}$, respectively, and the iron concentration was $1.10 \mathrm{mg} / \mathrm{L}$. Acidity was $14.8 \mathrm{mg} / \mathrm{L} \mathrm{CaCO}_{3}$, the calcium concentration was $73.2 \mathrm{mg} / \mathrm{L}$ as $\mathrm{CaCO}_{3}$, and the total hardness was $113 \mathrm{mg} / \mathrm{L}$ as $\mathrm{CaCO}_{3}$. Conductivity was $247 \mu \mathrm{S} / \mathrm{cm}$, which was within the limit set previously in Table 4.1 . Nitrate was $0.17 \mathrm{mg} / \mathrm{L}$, nitrite was below the detection limit, ammonia was $0.05 \mathrm{mg} / \mathrm{L}$, 
and phosphate was $0.02 \mathrm{mg} / \mathrm{L}$. Manganese was $3.00 \mathrm{mg} / \mathrm{L}$, aluminum was $2.51 \mathrm{mg} / \mathrm{L}$, and magnesium was $8.18 \mathrm{mg} / \mathrm{L}$. The metals and the aforementioned nutrients were tested by NRCCE.

Flow was measured as $0.004 \mathrm{~m}^{3} / \mathrm{s}$. Particle size analysis was performed on the sample collected at this site; however the particle concentration was not large enough to detect.

\subsubsection{Above the Spoils Pile, July 24, 2000}

The area surrounding Site $2 \mathrm{a}$ was forested and a considerable amount of silt and sediment were observed at the bottom of the stream. Evaluation was made of the water quality at Site $2 \mathrm{a}$ and all parameters, with the exception of aluminum, were within the limits previously identified in Table 4.1. The $\mathrm{pH}$ was 7.31 , the turbidity was $6.46 \mathrm{NTU}$, the conductivity was $26.7 \mu \mathrm{S} / \mathrm{cm}$, and the total suspended solids concentration was 6.35 $\mathrm{mg} / \mathrm{L}$. Alkalinity and acidity were $28.0 \mathrm{mg} / \mathrm{L}$ as $\mathrm{CaCO}_{3}$ and $3.22 \mathrm{mg} / \mathrm{L}$ as $\mathrm{CaCO}_{3}$, respectively. The sulfate concentration was below the detection limit of $7.5 \mathrm{mg} / \mathrm{L}$. Chloride and iron concentrations were $1.3 \mathrm{mg} / \mathrm{L}$ and $0.21 \mathrm{mg} / \mathrm{L}$, correspondingly. Manganese concentration was below the detection limit, aluminum was $0.16 \mathrm{mg} / \mathrm{L}$, and magnesium was $1.18 \mathrm{mg} / \mathrm{L}$. The calcium concentration was $16.2 \mathrm{mg} / \mathrm{L}$ as $\mathrm{CaCO}_{3}$ and the total hardness concentration was $21.4 \mathrm{mg} / \mathrm{L}$ as $\mathrm{CaCO}_{3}$. NRCCE reported $0.14 \mathrm{mg} / \mathrm{L}$ for nitrate concentration and nitrite, phosphate, and ammonia concentrations were below detection limits. 
Flow was measured as $0.002 \mathrm{~m}^{3} / \mathrm{s}$. Particle size analysis was performed on the sample collected at this site; however the particle concentration was not large enough to detect.

\subsubsection{Below the Spoils Pile, July 24, 2000}

Upon collection of the sample from Site $2 b$, immediately below the base of the spoils pile, it was observed that approximately 4" -6 " of silt and sediment had settled onto the streambed. This depth of sediment in the stream was detected throughout the length of the spoils pile. The spoils pile was enclosed by a steel fence.

By comparing the results of the water quality analyses with the standards in Table 4.1, it was determined that the $\mathrm{pH}$ of 4.81 was below the limit previously specified, manganese and aluminum concentrations exceeded acceptable limits. The other parameters were within the acceptable levels identified previously in Table 4.1. Alkalinity and acidity were $14.5 \mathrm{mg} / \mathrm{L}$ as $\mathrm{CaCO}_{3}$ and $18.7 \mathrm{mg} / \mathrm{L}$ as $\mathrm{CaCO}_{3}$, respectively, resulting in water that is net acidic. The turbidity was $11.6 \mathrm{NTU}$ and the total suspended solids concentration was $24.4 \mathrm{mg} / \mathrm{L}$. Conductivity was $186 \mu \mathrm{S} / \mathrm{cm}$, sulfate concentration was $69.4 \mathrm{mg} / \mathrm{L}$, iron concentration was $0.35 \mathrm{mg} / \mathrm{L}$, and chloride concentration was 3.5 mg/L. Manganese concentration was $2.11 \mathrm{mg} / \mathrm{L}$, aluminum was $3.18 \mathrm{mg} / \mathrm{L}$, and magnesium concentration was $5.10 \mathrm{mg} / \mathrm{L}$. The calcium concentration was $52.0 \mathrm{mg} / \mathrm{L}$ as $\mathrm{CaCO}_{3}$ and the total hardness was $78.6 \mathrm{mg} / \mathrm{L}$ as $\mathrm{CaCO}_{3}$. Nitrate concentration was 0.18

$\mathrm{mg} / \mathrm{L}$, nitrite and phosphate were below detection limits, and the ammonia concentration was $0.03 \mathrm{mg} / \mathrm{L}$. 
Flow was measured as $0.002 \mathrm{~m}^{3} / \mathrm{s}$. Particle size analysis was performed on the sample collected at this site; however the particle concentration was not large enough to detect.

\subsubsection{Middle Laurel Run, July 24, 2000}

Reddish orange staining was a predominant feature at the Middle Laurel Run site. Water levels were low and some water was impounded by a wall of trees and debris at the head of Site 3. The water quality parameters examined were within the limits specified previously in Table 4.1, with the exception of manganese and aluminum. Turbidity was $10.1 \mathrm{NTU}$ and the total suspended solids concentration was $4.10 \mathrm{mg} / \mathrm{L}$. The $\mathrm{pH}$ was 6.83 , alkalinity was $38.3 \mathrm{mg} / \mathrm{L}$ as $\mathrm{CaCO}_{3}$, and acidity was $7.19 \mathrm{mg} / \mathrm{L}$ as $\mathrm{CaCO}_{3}$. Conductivity was $582 \mu \mathrm{S} / \mathrm{cm}$, sulfate concentration was $106 \mathrm{mg} / \mathrm{L}$, and iron and chloride concentrations were $0.79 \mathrm{mg} / \mathrm{L}$ and $54.2 \mathrm{mg} / \mathrm{L}$, respectively. Manganese was $5.27 \mathrm{mg} / \mathrm{L}$, aluminum was $0.12 \mathrm{mg} / \mathrm{L}$, and magnesium was $14.8 \mathrm{mg} / \mathrm{L}$. The calcium concentration was $146 \mathrm{mg} / \mathrm{L}$ as $\mathrm{CaCO}_{3}$ and the total hardness was $224 \mathrm{mg} / \mathrm{L}$ as $\mathrm{CaCO}_{3}$. Nitrite concentration was below the detection limit, nitrate concentration was $0.12 \mathrm{mg} / \mathrm{L}$, ammonia was $0.45 \mathrm{mg} / \mathrm{L}$, and phosphate was $0.010 \mathrm{mg} / \mathrm{L}$.

Flow was not measured, as insufficient water was present to fill the flow meter conduit. Particle size analysis was performed on the sample collected at this site; however the particle concentration was not large enough to detect. 


\subsubsection{Above the Sedimentation Pond, July 24, 2000}

Noticeable oil and grease was observed floating on the surface of the water at the inlet of the sedimentation pond. More concentrated portions of the oily residue were observed along the edges of the stream. Reddish orange staining was observed on the concrete culvert draining into Site $3 \mathrm{a}$ and on the rocks protruding from the body of water. The water itself was orange and the scent of "rust" was noticeable. Further, suspended orange particles in the sample were noted. These particles were present in the laboratory samples as well. Black acidic seeps from the spoils pile which drains into the sedimentation pond were also observed on the hillside.

Upon evaluating the water quality data with the standards in Table 4.1, it was determined that Site $3 \mathrm{a}$ is not suitable for aquatic life. Iron, manganese, and aluminum concentrations exceeded the limits presented previously in Table 4.1, the $\mathrm{pH}$ was 6.07 , which was below the limit. Turbidity and total suspended solids concentration were 8.78 NTU and $6.75 \mathrm{mg} / \mathrm{L}$, respectively. Conductivity was $831 \mu \mathrm{S} / \mathrm{cm}$, sulfate concentration was $113 \mathrm{mg} / \mathrm{L}$, and chloride concentration was $79.5 \mathrm{mg} / \mathrm{L}$. The iron concentration was $36.1 \mathrm{mg} / \mathrm{L}$. The alkalinity was $90.3 \mathrm{mg} / \mathrm{L}$ as $\mathrm{CaCO}_{3}$ and acidity was $105.5 \mathrm{mg} / \mathrm{L}$ as $\mathrm{CaCO}_{3}$, resulting in water that was net acidic. Manganese was $10.5 \mathrm{mg} / \mathrm{L}$, aluminum was $0.14 \mathrm{mg} / \mathrm{L}$, and magnesium was $23.6 \mathrm{mg} / \mathrm{L}$. Calcium and total hardness concentrations could not be determined due to the presence of an interfering species (most probably the oil and grease in the water sample). Nitrite concentration was below the detection limit. Nitrate concentration was $0.02 \mathrm{mg} / \mathrm{L}$, phosphate concentration was $0.01 \mathrm{mg} / \mathrm{L}$, and ammonia was $1.00 \mathrm{mg} / \mathrm{L}$. 
Flow was not measured, as insufficient water was present to fill the flow meter conduit. Particle size analysis was performed on the sample collected at this site; however the particle concentration was not large enough to detect.

\subsubsection{Below the Sedimentation Pond, July 24, 2000}

Site $3 \mathrm{~b}$, the site below the sedimentation pond, had orange water and reddish orange staining on the rocks and sediment in the vicinity. A notable amount of sediment was observed at the bottom of the stream.

Through evaluation of the water quality data from Site $3 \mathrm{~b}$, it was determined that the water quality parameters were within the limits identified previously in Table 4.1, with the exception of manganese. The $\mathrm{pH}$ was 6.74 , alkalinity was $33.9 \mathrm{mg} / \mathrm{L}$ as $\mathrm{CaCO}_{3}$, and acidity was $5.13 \mathrm{mg} / \mathrm{L}$ as $\mathrm{CaCO}_{3}$. Turbidity was $18.2 \mathrm{NTU}$ and total suspended solids concentration was $4.95 \mathrm{mg} / \mathrm{L}$. Conductivity was $549 \mu \mathrm{S} / \mathrm{cm}$, sulfate concentration was $106 \mathrm{mg} / \mathrm{L}$, iron concentration was $0.50 \mathrm{mg} / \mathrm{L}$, and chloride concentration was 53.5 $\mathrm{mg} / \mathrm{L}$. The calcium concentration was $149 \mathrm{mg} / \mathrm{L}$ as $\mathrm{CaCO}_{3}$ and the total hardness was $227 \mathrm{mg} / \mathrm{L}$ as $\mathrm{CaCO}_{3}$. Nitrite, phosphate, and aluminum concentrations were below the detection limits. Nitrate was $0.09 \mathrm{mg} / \mathrm{L}$, ammonia was $0.50 \mathrm{mg} / \mathrm{L}$, manganese was 5.06 $\mathrm{mg} / \mathrm{L}$, and magnesium was $14.7 \mathrm{mg} / \mathrm{L}$, as reported by the NRCCE. Manganese concentration was above the limit in Table 4.1.

Flow was not measured, as insufficient water was present to fill the flow meter conduit. The particle size analysis distribution for Site $3 \mathrm{~b}$, below the sedimentation pond, is presented in Figure 4.12. The mean particle diameter was $29.2 \mu \mathrm{m}$. 


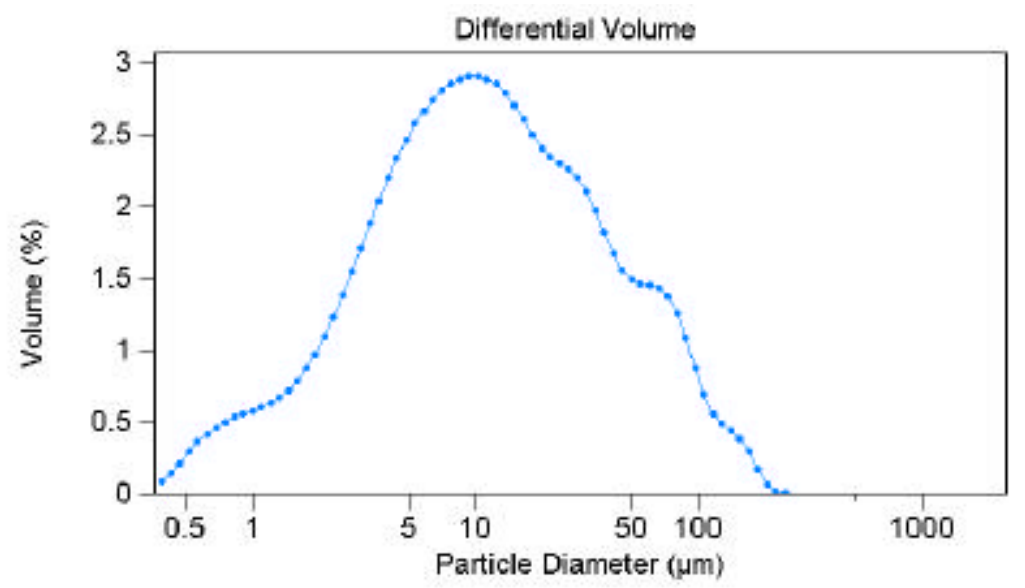

Figure 4.12. Particle Size Distribution for Below the Sedimentation Pond (Site 3b), July 24, 2000.

\subsubsection{Upper Laurel Run, July 24, 2000}

A large quantity of sediment and silt in the stream was observed at the Upper Laurel Run site. This site is located near the outlet of the blown out sedimentation pond constructed at Camp Seefus.

The water quality data from Site 4 were in compliance with the standards in Table 4.1. Turbidity was 11.4 NTU and total suspended solids were $2.17 \mathrm{mg} / \mathrm{L}$. Alkalinity and acidity were $33.9 \mathrm{mg} / \mathrm{L}$ as $\mathrm{CaCO}_{3}$ and $5.13 \mathrm{mg} / \mathrm{L}$ as $\mathrm{CaCO}_{3}$, respectively. Conductivity was $178 \mu \mathrm{S} / \mathrm{cm}$, sulfate concentration was $37.2 \mathrm{mg} / \mathrm{L}$, chloride concentration was 16.5 $\mathrm{mg} / \mathrm{L}$, and iron concentration was $0.62 \mathrm{mg} / \mathrm{L}$. The calcium concentration was $38.4 \mathrm{mg} / \mathrm{L}$ as $\mathrm{CaCO}_{3}$ and the total hardness was $58.2 \mathrm{mg} / \mathrm{L}$ as $\mathrm{CaCO}_{3}$. Nitrite, phosphate, and aluminum concentrations were below detection limits. Nitrate concentration was 0.09 $\mathrm{mg} / \mathrm{L}$, ammonia concentration was $0.01 \mathrm{mg} / \mathrm{L}$, manganese concentration was $0.217 \mathrm{mg} / \mathrm{L}$, and magnesium concentration was $4.25 \mathrm{mg} / \mathrm{L}$, as reported by the NRCCE. The manganese concentration was above the limit in Table 4.1 . 
Flow was not measured, as insufficient water was present to fill the flow meter conduit. Particle size analysis was performed on the sample collected at this site; however the particle concentration was not large enough to detect.

\subsubsection{The Bench Drainage, July 24, 2000}

A comparison with the criteria presented previously in Table 4.1 was made and it was determined that Site 5 is not an inhabitable stream. The $\mathrm{pH}$ was 3.19 , which was below the limit, and iron, manganese, and aluminum exceeded the limits presented previously in Table 4.1. Other parameters were within the acceptable levels: turbidity was $0.37 \mathrm{NTU}$, total suspended solids concentration was $0.85 \mathrm{mg} / \mathrm{L}$ and conductivity was $698 \mu \mathrm{S} / \mathrm{cm}$. Alkalinity could not be determined since the sample $\mathrm{pH}$ was below the methyl orange indicator titrametric endpoint (4.3). Acidity was $69.8 \mathrm{mg} / \mathrm{L}$. Iron concentration was $5.12 \mathrm{mg} / \mathrm{L}$. Manganese was $2.19 \mathrm{mg} / \mathrm{L}$, aluminum was $1.53 \mathrm{mg} / \mathrm{L}$, and magnesium was $13.7 \mathrm{mg} / \mathrm{L}$. The sulfate concentration was $112 \mathrm{mg} / \mathrm{L}$, chloride concentration was $1.0 \mathrm{mg} / \mathrm{L}$, and the calcium concentration was $103 \mathrm{mg} / \mathrm{L}$ as $\mathrm{CaCO}_{3}$. The total hardness could not be determined due to an interfering species in the sample (i.e., oil and grease, and dissolved metal concentration (APHA 1998)). All the nutrient concentrations (nitrate, nitrite, ammonia, and phosphate) were below the detection limits.

Flow was measured as $0.002 \mathrm{~m}^{3} / \mathrm{s}$. Particle size analysis was performed on the sample collected at this site; however the particle concentration was not large enough to detect. 


\subsection{SAMPLING TRIP 4, AUGUST 27, 2000}

On August 27, 2000, an additional sample was taken at each site as identified in

Figure 3.1. The results of the water quality analyses performed for the samples collected on August 27, 2000 are presented in Table 4.6. 
Table 4.6. Results of Water Quality Analyses for August 27, 2000.

\begin{tabular}{|c|c|c|c|c|c|c|c|c|c|}
\hline & Site 1 & Site 2 & $\begin{array}{l}\text { Site } \\
\text { 2a }\end{array}$ & $\begin{array}{l}\text { Site } \\
\text { 2b }\end{array}$ & Site 3 & $\begin{array}{l}\text { Site } \\
\text { 3a }\end{array}$ & $\begin{array}{c}\text { Site } \\
\text { 3b }\end{array}$ & Site 4 & Site 5 \\
\hline $\begin{array}{c}\text { Turbidity } \\
\text { (NTU) }\end{array}$ & 3.00 & 9.52 & 14.3 & 11.4 & 39.6 & 17.7 & 114.0 & 2.86 & 0.26 \\
\hline pH & 7.28 & 6.34 & 7.19 & 5.79 & 6.76 & 6.18 & 6.58 & 6.91 & 3.25 \\
\hline $\begin{array}{c}\text { Conductivity } \\
(\mu \mathrm{S} / \mathrm{cm})\end{array}$ & 171 & 159 & 57.9 & 111 & 40.5 & 631 & 69.8 & 156 & 672 \\
\hline TSS (mg/L) & 6.15 & 15.0 & 11.6 & 12.8 & 13.4 & 13.1 & 12.6 & 4.63 & 0.200 \\
\hline $\begin{array}{c}\text { Alkalinity } \\
\text { (mg/L as } \\
\left.\mathrm{CaCO}_{3}\right)\end{array}$ & 24.7 & 19.9 & 29.0 & 15.2 & 26.7 & 72.2 & 23.6 & 29.7 & -- \\
\hline $\begin{array}{c}\text { Acidity } \\
(\mathrm{mg} / \mathrm{L} \text { as } \\
\left.\mathrm{CaCO}_{3}\right)\end{array}$ & 2.12 & 5.66 & 2.00 & 4.74 & 5.96 & 62.8 & 5.86 & 3.14 & 69.8 \\
\hline $\begin{array}{l}\text { Sulfate } \\
(\mathrm{mg} / \mathrm{L})\end{array}$ & 50.4 & 58.7 & 9.80 & 42.8 & 144 & 252 & 164 & 40.1 & 293 \\
\hline $\begin{array}{c}\text { Chloride } \\
\text { (mg/L) }\end{array}$ & 11.5 & 2.6 & BDL & BDL & 26.0 & 52.0 & 26.0 & 9.5 & $\mathrm{BDL}$ \\
\hline Iron $(\mathrm{mg} / \mathrm{L})$ & 0.15 & 0.41 & 0.18 & 0.10 & 0.84 & 19.8 & 0.21 & 0.32 & 6.91 \\
\hline $\begin{array}{l}\text { Calcium } \\
(\mathrm{mg} / \mathrm{L} \text { as } \\
\left.\mathrm{CaCO}_{3}\right)\end{array}$ & 39.80 & 44.40 & 18.60 & 29.60 & 110.2 & 154.6 & 107.3 & 35.40 & 106.0 \\
\hline $\begin{array}{c}\text { Total } \\
\text { Hardness } \\
\text { (mg/L as } \\
\text { CaCO }_{3} \text { ) }\end{array}$ & 61.2 & 65.40 & 23.80 & 43.80 & 158.6 & $* *$ & 162.2 & 53.60 & $* *$ \\
\hline $\begin{array}{l}\text { Nitrate } \\
(\mathrm{mg} / \mathrm{L})\end{array}$ & 0.17 & 0.16 & 0.13 & 0.17 & 0.22 & 0.07 & 0.43 & 0.13 & BDL \\
\hline $\begin{array}{l}\text { Nitrite } \\
\text { (mg/L) }\end{array}$ & BDL & BDL & BDL & BDL & BDL & $\mathrm{BDL}$ & BDL & $\mathrm{BDL}$ & $\mathrm{BDL}$ \\
\hline $\begin{array}{c}\text { Ammonia } \\
(\mathrm{mg} / \mathrm{L})\end{array}$ & BDL & 0.04 & $\mathrm{BDL}$ & 0.02 & 0.21 & 0.59 & 0.22 & BDL & $\mathrm{BDL}$ \\
\hline $\begin{array}{c}\text { Phosphate } \\
\text { (mg/L) }\end{array}$ & BDL & 0.02 & BDL & 0.01 & $\mathrm{BDL}$ & $\mathrm{BDL}$ & BDL & $\mathrm{BDL}$ & 0.05 \\
\hline $\begin{array}{c}\text { Manganese } \\
(\mathrm{mg} / \mathrm{L})\end{array}$ & 0.29 & 1.37 & BDL & 0.96 & 2.88 & 5.90 & 2.31 & 0.18 & 2.45 \\
\hline$\underset{(m g / L)}{\text { Aluminum }}$ & 0.27 & 1.79 & 0.140 & 1.79 & 0.25 & 0.36 & 0.55 & 0.11 & 1.92 \\
\hline $\begin{array}{c}\text { Magnesium } \\
(\mathrm{mg} / \mathrm{L})\end{array}$ & 4.33 & 3.80 & 1.04 & 2.54 & 9.71 & 15.6 & 9.59 & 4.01 & 15.0 \\
\hline
\end{tabular}

** presence of interfering species in water sample.

-- starting $\mathrm{pH}<4.3$, methyl orange indicator titrametric endpoint.

$\mathrm{BDL}=$ below detection limit (presented previously in Table 3.2.) 
Comparing the data from the water quality analyses with criteria presented previously in Table 4.1, five parameters exceed the specified limits: $\mathrm{pH}$, iron concentration, conductivity, manganese concentration, and aluminum concentration. For $\mathrm{pH}$, four sites were below the range: the box culvert had a $\mathrm{pH}$ of 6.34 , the sampling site below the spoils pile had a $\mathrm{pH}$ of 5.79 , above the sedimentation pond had a $\mathrm{pH}$ of 6.18 , and the bench drainage had a $\mathrm{pH}$ of 3.25. Two sites exceeded the limit for conductivity: above the sedimentation pond, $631 \mu \mathrm{S} / \mathrm{cm}$ and the bench drainage, $672 \mu \mathrm{S} / \mathrm{cm}$. The same sites had iron concentrations which were too high; above the sedimentation pond had $19.8 \mathrm{mg} / \mathrm{L}$ of iron and the bench drainage had $6.91 \mathrm{mg} / \mathrm{L}$ of iron. Five sites exceeded the limit for manganese: the box culvert, $1.37 \mathrm{mg} / \mathrm{L}$, Middle Laurel Run, $2.88 \mathrm{mg} / \mathrm{L}$, above the sedimentation pond, $5.90 \mathrm{mg} / \mathrm{L}$, below the sedimentation pond, $2.31 \mathrm{mg} / \mathrm{L}$, and the bench drainage, $2.45 \mathrm{mg} / \mathrm{L}$. All the sites exceeded the limit for aluminum.

\subsubsection{Lower Laurel Run, August 27, 2000}

The parameters sampled at Lower Laurel Run were within the given limits of Table 4.1, except for the aluminum concentration, which was $0.27 \mathrm{mg} / \mathrm{L}$. Turbidity was 3.00 NTU and total suspended solids concentration was $6.15 \mathrm{mg} / \mathrm{L}$. Alkalinity and acidity were $19.9 \mathrm{mg} / \mathrm{L}$ as $\mathrm{CaCO}_{3}$ and $2.12 \mathrm{mg} / \mathrm{L}$ as $\mathrm{CaCO}_{3}$, respectively. Conductivity was $171 \mu \mathrm{S} / \mathrm{cm}$ and $\mathrm{pH}$ was 7.28 . Sulfate, iron, and chloride concentrations were 50.4 $\mathrm{mg} / \mathrm{L}, 0.15 \mathrm{mg} / \mathrm{L}$, and $11.5 \mathrm{mg} / \mathrm{L}$, correspondingly. Manganese concentration was 0.29 $\mathrm{mg} / \mathrm{L}$. Calcium was $39.80 \mathrm{mg} / \mathrm{L}$ as $\mathrm{CaCO}_{3}$, magnesium was $4.33 \mathrm{mg} / \mathrm{L}$, and total hardness was $61.2 \mathrm{mg} / \mathrm{L}$ as $\mathrm{CaCO}_{3}$. Nitrate concentration was $0.17 \mathrm{mg} / \mathrm{L}$. Ammonia, nitrite, and phosphate concentrations were below detection limits. 
Flow was measured as $0.103 \mathrm{~m}^{3} / \mathrm{s}$. Particle size analysis was performed on the sample collected at this site; however the particle concentration was not large enough to detect.

\subsubsection{The Box Culvert, August 27, 2000}

The water quality parameters at Site 2 were within the limits specified previously in Table 4.1, with the exception of manganese and aluminum concentrations, and $\mathrm{pH}$. The $\mathrm{pH}$ was 6.34, which was below the range designated previously in Table 4.1. Turbidity and total suspended solids concentration were $9.52 \mathrm{NTU}$ and $15.0 \mathrm{mg} / \mathrm{L}$, respectively. Conductivity was $159 \mu \mathrm{S} / \mathrm{cm}$. Acidity was $5.66 \mathrm{mg} / \mathrm{L}$ as $\mathrm{CaCO}_{3}$ and alkalinity was $19.9 \mathrm{mg} / \mathrm{L}$ as $\mathrm{CaCO}_{3}$. Sulfate, iron, and chloride concentrations were 58.7 $\mathrm{mg} / \mathrm{L}, 0.41 \mathrm{mg} / \mathrm{L}$, and $2.6 \mathrm{mg} / \mathrm{L}$. Aluminum was $1.79 \mathrm{mg} / \mathrm{L}$ and manganese was 1.37 mg/L. Calcium was $44.40 \mathrm{mg} / \mathrm{L}$ as $\mathrm{CaCO}_{3}$, magnesium was $3.80 \mathrm{mg} / \mathrm{L}$, and total hardness was $65.40 \mathrm{mg} / \mathrm{L}$ as $\mathrm{CaCO}_{3}$. Nitrate concentration was $0.16 \mathrm{mg} / \mathrm{L}$, ammonia concentration was $0.04 \mathrm{mg} / \mathrm{L}$, and phosphate concentration was $0.02 \mathrm{mg} / \mathrm{L}$.

Flow was not measured, as insufficient water was present to fill the flow meter conduit. Particle size analysis was performed on the sample collected at this site; however the particle concentration was not large enough to detect.

\subsubsection{Above the Spoils Pile, August 27, 2000}

Aluminum was the only parameter tested that exceeded the limits specified previously in Table 4.1, with a concentration of $0.140 \mathrm{mg} / \mathrm{L}$, as reported by the NRCCE. The chloride, ammonia, nitrite, phosphate, and manganese were below the detection 
limits. Turbidity, $\mathrm{pH}$, and conductivity were $14.3 \mathrm{NTU}, 7.19$, and $57.9 \mu \mathrm{S} / \mathrm{cm}$, respectively. Total suspended solids concentration was $11.6 \mathrm{mg} / \mathrm{L}$. Alkalinity was 19.9 $\mathrm{mg} / \mathrm{L}$ as $\mathrm{CaCO}_{3}$ and acidity was $5.66 \mathrm{mg} / \mathrm{L}$ as $\mathrm{CaCO}_{3}$. Sulfate was $9.80 \mathrm{mg} / \mathrm{L}$ and iron was $0.18 \mathrm{mg} / \mathrm{L}$. Calcium was $18.60 \mathrm{mg} / \mathrm{L}$ as $\mathrm{CaCO}_{3}$, total hardness was $23.80 \mathrm{mg} / \mathrm{L}$ as $\mathrm{CaCO}_{3}$, and magnesium was $1.04 \mathrm{mg} / \mathrm{L}$. Nitrate concentration was $0.13 \mathrm{mg} / \mathrm{L}$.

Flow was not measured, as insufficient water was present to fill the flow meter conduit. Particle size distribution is presented in Figure 4.13. The mean particle diameter above the spoils pile, Site $2 \mathrm{a}$, was $69.5 \mu \mathrm{m}$.

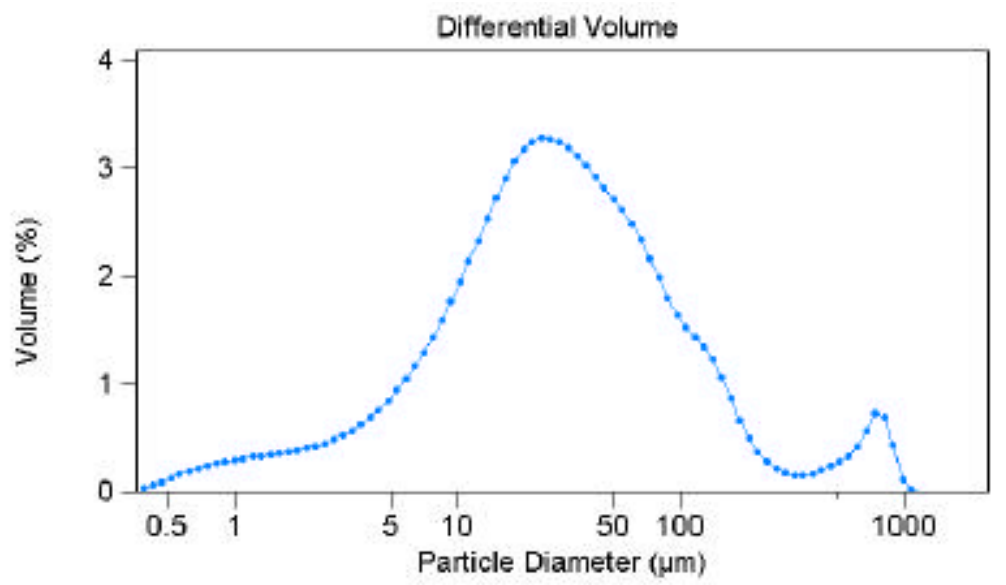

Figure 4.13. Particle Size Distribution for Above the Spoils Pile (Site 2a), August 27, 2000.

\subsubsection{Below the Spoils Pile, August 27, 2000}

The $\mathrm{pH}$ and the aluminum concentrations exceeded the limits set previously in Table 4.1 at the site sampled below the spoils pile. Aluminum concentration was 1.79 $\mathrm{mg} / \mathrm{L}$ and $\mathrm{pH}$ was 5.79. The other parameters examined were within acceptable limits. Turbidity was $11.4 \mathrm{NTU}$ and conductivity was $111 \mu \mathrm{S} / \mathrm{cm}$. Total suspended solids concentration was $12.8 \mathrm{mg} / \mathrm{L}$. Alkalinity and acidity were $15.2 \mathrm{mg} / \mathrm{L}$ as $\mathrm{CaCO}_{3}$ and 4.74 
$\mathrm{mg} / \mathrm{L}$ as $\mathrm{CaCO}_{3}$, respectively. The chloride concentration was below the detection limit of $1.0 \mathrm{mg} / \mathrm{L}$. Sulfate concentration was $42.8 \mathrm{mg} / \mathrm{L}$, iron concentration was $0.10 \mathrm{mg} / \mathrm{L}$, and manganese concentration was $0.96 \mathrm{mg} / \mathrm{L}$. Calcium was $18.60 \mathrm{mg} / \mathrm{L}$ as $\mathrm{CaCO}_{3}$, total hardness was $43.80 \mathrm{mg} / \mathrm{L}$ as $\mathrm{CaCO}_{3}$, and magnesium was $2.54 \mathrm{mg} / \mathrm{L}$. Nitrate concentration was $0.17 \mathrm{mg} / \mathrm{L}$, ammonia concentration was $0.02 \mathrm{mg} / \mathrm{L}$, and phosphate concentration was $0.01 \mathrm{mg} / \mathrm{L}$. Nitrite concentration was below detection limits.

Flow was not measured, as insufficient water was present to fill the flow meter conduit. Particle size analysis was performed on the sample collected at this site; however the particle concentration was not large enough to detect.

\subsubsection{Middle Laurel Run, August 27, 2000}

Middle Laurel Run is a connector site for the station below the sedimentation pond and Laurel Run. At Site 3, aluminum and manganese concentrations exceeded the limits specified previously in Table 4.1; the other parameters were within these limits. Turbidity was $39.6 \mathrm{NTU}$ and total suspended solids concentration was $13.4 \mathrm{mg} / \mathrm{L} . \mathrm{pH}$ was 6.76. Alkalinity and acidity were $26.7 \mathrm{mg} / \mathrm{L}$ as $\mathrm{CaCO}_{3}$ and $5.96 \mathrm{mg} / \mathrm{L}$ as $\mathrm{CaCO}_{3}$, respectively. Conductivity was $40.5 \mu \mathrm{S} / \mathrm{cm}$, sulfate concentration was $144 \mathrm{mg} / \mathrm{L}$, iron concentration was $0.84 \mathrm{mg} / \mathrm{L}$, and chloride concentration was $26.0 \mathrm{mg} / \mathrm{L}$. Aluminum and manganese concentrations were $0.25 \mathrm{mg} / \mathrm{L}$ and $2.88 \mathrm{mg} / \mathrm{L}$, respectively. Calcium was $110.2 \mathrm{mg} / \mathrm{L}$ as $\mathrm{CaCO}_{3}$, total hardness was $158.6 \mathrm{mg} / \mathrm{L}$ as $\mathrm{CaCO}_{3}$, and magnesium was $9.71 \mathrm{mg} / \mathrm{L}$. Nitrate concentration was $0.22 \mathrm{mg} / \mathrm{L}$ and ammonia concentration was 0.21 $\mathrm{mg} / \mathrm{L}$. Nitrite and phosphate concentrations were below detection limits. 
Flow was not measured, as insufficient water was present to fill the flow meter conduit. Particle size analysis was performed on the sample collected at Middle Laurel Run. Particle size distribution for Middle Laurel Run is presented in Figure 4.14 and the mean particle diameter was $17.78 \mu \mathrm{m}$.

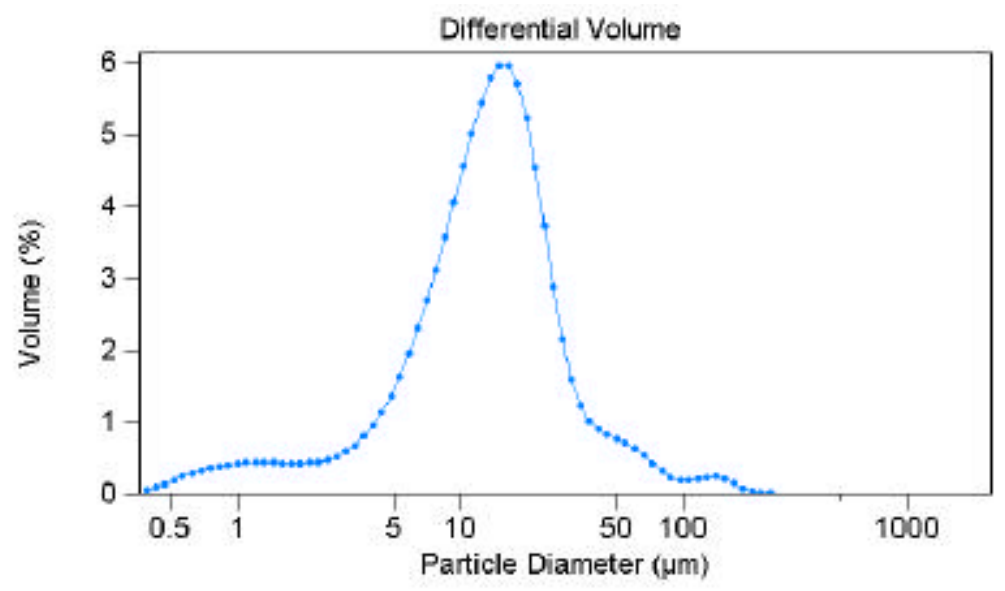

Figure 4.14. Particle Size Distribution for Middle Laurel Run (Site 3), August 27, 2000.

\subsubsection{Above the Sedimentation Pond, August 27, 2000}

With the exception of $\mathrm{pH}$, iron concentration, conductivity, manganese concentration, and aluminum concentration, the parameters evaluated above the sedimentation pond were within the limits specified previously in Table 4.1. Turbidity was $17.7 \mathrm{NTU}$ and total suspended solids concentration was $13.1 \mathrm{mg} / \mathrm{L}$. The $\mathrm{pH}$ was 6.18. Alkalinity and acidity were $72.2 \mathrm{mg} / \mathrm{L}$ as $\mathrm{CaCO}_{3}$ and $62.8 \mathrm{mg} / \mathrm{L}$ as $\mathrm{CaCO}_{3}$, respectively. Conductivity was $631 \mu \mathrm{S} / \mathrm{cm}$, the iron concentration was $19.9 \mathrm{mg} / \mathrm{L}$, sulfate concentration was $252 \mathrm{mg} / \mathrm{L}$, and chloride concentration was $52.0 \mathrm{mg} / \mathrm{L}$. Manganese concentration was $5.90 \mathrm{mg} / \mathrm{L}$ and the aluminum concentration was $0.36 \mathrm{mg} / \mathrm{L}$. Calcium was $154.6 \mathrm{mg} / \mathrm{L}$ as $\mathrm{CaCO}_{3}$ and magnesium was $15.6 \mathrm{mg} / \mathrm{L}$. The total hardness could not 
be determined due to the presence of an interfering species in the water. Nitrate concentration was $0.07 \mathrm{mg} / \mathrm{L}$ and ammonia concentration was $0.59 \mathrm{mg} / \mathrm{L}$ and nitrite and phosphate concentrations were below detection limits.

Flow was not measured, as insufficient water was present to fill the flow meter conduit. Particle size distribution is presented in Figure 4.15. The mean particle diameter above the sedimentation pond was $42.27 \mu \mathrm{m}$.

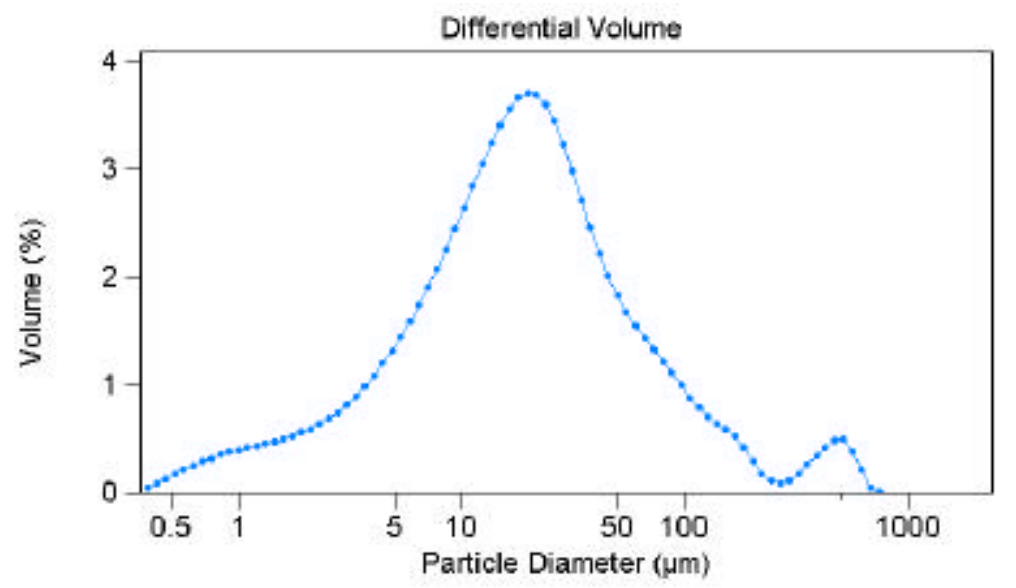

Figure 4.15. Particle Size Distribution for Above the Sedimentation Pond (Site 3a), August 27, 2000.

\subsubsection{Below the Sedimentation Pond, August 27, 2000}

At the site below the sedimentation pond, the water quality parameters were within the limits specified previously in Table 4.1 with the exception of aluminum and manganese. Turbidity was 114.0 NTU and total suspended solids concentration was 12.6 $\mathrm{mg} / \mathrm{L}$. $\mathrm{pH}$ was 6.58 . Alkalinity was $23.6 \mathrm{mg} / \mathrm{L}$ as $\mathrm{CaCO}_{3}$ and acidity was $5.86 \mathrm{mg} / \mathrm{L}$ as $\mathrm{CaCO}_{3}$. Conductivity was $69.8 \mu \mathrm{S} / \mathrm{cm}$. Sulfate was $164 \mathrm{mg} / \mathrm{L}$, chloride was $26.0 \mathrm{mg} / \mathrm{L}$, and iron concentration was $0.21 \mathrm{mg} / \mathrm{L}$. Manganese concentration was $2.31 \mathrm{mg} / \mathrm{L}$ and 
aluminum concentration was $0.55 \mathrm{mg} / \mathrm{L}$. Calcium was $107.3 \mathrm{mg} / \mathrm{L}$ as $\mathrm{CaCO}_{3}$, total hardness was $162.2 \mathrm{mg} / \mathrm{L}$ as $\mathrm{CaCO}_{3}$, and magnesium was $9.59 \mathrm{mg} / \mathrm{L}$. Nitrate concentration was $0.43 \mathrm{mg} / \mathrm{L}$, ammonia concentration was $0.22 \mathrm{mg} / \mathrm{L}$ and nitrite and phosphate concentrations were below detection limits.

Flow was not measured, as insufficient water was present to fill the flow meter conduit. The particle size distribution is presented in Figure 4.16. The mean diameter of the particles in the sample collected below the sedimentation pond was $16.62 \mu \mathrm{m}$.

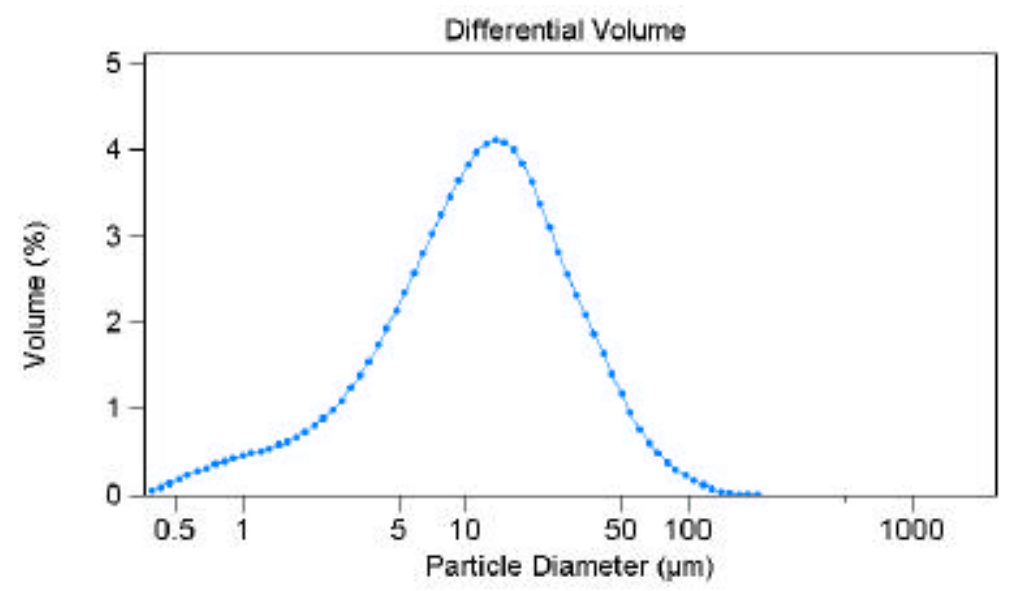

\section{Figure 4.16. Particle Size Distribution for Below the Sedimentation Pond (Site 3b), August 27, 2000.}

\subsubsection{Upper Laurel Run, August 27, 2000}

Aluminum concentration was the only parameter which was not within the limits previously identified in Table 4.1. Turbidity was 2.86 NTU and total suspended solids concentration was $4.63 \mathrm{mg} / \mathrm{L}$. pH was 6.91 . Alkalinity was $29.7 \mathrm{mg} / \mathrm{L}$ as $\mathrm{CaCO}_{3}$ and acidity was $3.14 \mathrm{mg} / \mathrm{L}$ as $\mathrm{CaCO}_{3}$. Conductivity was $156 \mu \mathrm{S} / \mathrm{cm}$, sulfate concentration was $40.1 \mathrm{mg} / \mathrm{L}$, iron concentration was $0.32 \mathrm{mg} / \mathrm{L}$, and chloride concentration was $9.5 \mathrm{mg} / \mathrm{L}$. Manganese concentration was $0.18 \mathrm{mg} / \mathrm{L}$ and aluminum concentration was $0.11 \mathrm{mg} / \mathrm{L}$. 
Calcium, total hardness, and magnesium were $35.40 \mathrm{mg} / \mathrm{L}$ as $\mathrm{CaCO}_{3}, 53.60 \mathrm{mg} / \mathrm{L}$ as $\mathrm{CaCO}_{3}$, and $4.01 \mathrm{mg} / \mathrm{L}$, respectively. Nitrate concentration was $0.13 \mathrm{mg} / \mathrm{L}$; nitrite, ammonia and phosphate concentrations were below detection limits.

Flow was not measured, as insufficient water was present to fill the flow meter conduit. Particle size analysis was performed on the sample collected at this site; however the particle concentration was not large enough to detect.

\subsubsection{The Bench Drainage, August 27, 2000}

With the exception of five parameters $(\mathrm{pH}$, conductivity, iron concentration, manganese concentration, and aluminum concentration) the water quality data was within the limits specified previously in Table 4.1. Turbidity was $0.26 \mathrm{NTU}$ and total suspended solids concentration was $0.200 \mathrm{mg} / \mathrm{L}$. The $\mathrm{pH}$ was 3.25 . Alkalinity could not be determined because the sample $\mathrm{pH}$ was below the methyl orange indicator titrametric endpoint, 4.3. The acidity was $69.8 \mathrm{mg} / \mathrm{L}$ as $\mathrm{CaCO}_{3}$. Conductivity was $672 \mu \mathrm{S} / \mathrm{cm}$, sulfate concentration was $293 \mathrm{mg} / \mathrm{L}$, iron concentration was $6.91 \mathrm{mg} / \mathrm{L}$, manganese concentration was $2.45 \mathrm{mg} / \mathrm{L}$, and aluminum concentration was $1.92 \mathrm{mg} / \mathrm{L}$. The chloride concentration, the nitrate concentration, the nitrite concentration, and the ammonia concentration were below detection limits. Calcium was $106.0 \mathrm{mg} / \mathrm{L}$ as $\mathrm{CaCO}_{3}$ and magnesium was $15.0 \mathrm{mg} / \mathrm{L}$. The total hardness could not be determined due to an interfering species present in the water sample. Phosphate concentration was $0.05 \mathrm{mg} / \mathrm{L}$.

Flow was not measured, as insufficient water was present to fill the flow meter conduit. Particle size analysis was performed on the sample collected at this site; however the particle concentration was not large enough to detect. 


\subsection{CONSTRUCTION PLANS}

On August 2, 2000, a meeting was scheduled between Mr. Neal Carte, WVDOH Environmental Services Group, and Ms. Jaime Sayre, WVU-CEE graduate research assistant, in order for Ms. Sayre to obtain the construction plans for the segments of Corridor $H$ that intercepts Laurel Run and Tygart Valley River. Upon acquiring the documents, the core samples were identified and the strata supporting the highway were evaluated. The core samples relevant to the sites sampled on Laurel Run are presented in Appendix A, Table 7.1. Upon examination of the core sample data, it was determined that the highway cores contained shale, coal seams, and old mine spoils.

\subsection{SAMPLING TRIP 5, SEPTEMBER 26, 2000}

On September 26, 2000, an additional sample was taken at each site as identified in Figure 3.1. The results of the water quality analyses performed for the samples collected on September 26, 2000 are presented in Table 4.7. 
Table 4.7. Results of Water Quality Analyses for September 26, 2000.

\begin{tabular}{|c|c|c|c|c|c|c|c|c|c|}
\hline & Site 1 & Site 2 & $\begin{array}{l}\text { Site } \\
\text { 2a }\end{array}$ & $\begin{array}{c}\text { Site } \\
\text { 2b }\end{array}$ & Site 3 & $\begin{array}{c}\text { Site } \\
\text { 3a }\end{array}$ & $\begin{array}{l}\text { Site } \\
\text { 3b }\end{array}$ & Site 4 & Site 5 \\
\hline $\begin{array}{c}\text { Turbidity } \\
\text { (NTU) }\end{array}$ & 10.1 & 37.6 & 17.0 & 19.2 & 6.62 & 34.8 & 7.75 & 6.08 & 0.46 \\
\hline pH & 7.15 & 5.89 & 6.75 & 6.07 & 6.30 & 6.32 & 6.43 & 6.77 & 3.5 \\
\hline $\begin{array}{c}\text { Conductivity } \\
(\mu \mathrm{S} / \mathrm{cm})\end{array}$ & 96.7 & 74.2 & 46.0 & 69.3 & 187 & 174 & 185 & 108 & 514 \\
\hline TSS (mg/L) & 17.4 & 25.4 & 15.8 & 23.5 & 6.27 & 58.9 & 8.00 & 4.35 & 0.45 \\
\hline $\begin{array}{c}\text { Alkalinity } \\
\text { (mg/L as } \\
\left.\mathrm{CaCO}_{3}\right)\end{array}$ & 20.5 & 15.0 & 20.3 & 15.1 & 19.8 & 23.4 & 20.9 & 25.1 & -- \\
\hline $\begin{array}{c}\text { Acidity } \\
(\mathrm{mg} / \mathrm{L} \text { as } \\
\left.\mathrm{CaCO}_{3}\right)\end{array}$ & 1.80 & 3.92 & 2.22 & 4.04 & 8.32 & 9.76 & 7.38 & 2.92 & 54.1 \\
\hline $\begin{array}{l}\text { Sulfate } \\
\text { (mg/L) }\end{array}$ & 27.2 & 23.4 & 5.80 & 19.0 & 54.5 & 54.0 & 53.0 & 19.4 & 163 \\
\hline $\begin{array}{c}\text { Chloride } \\
\text { (mg/L) }\end{array}$ & 4.6 & 1.2 & BDL & BDL & 6.9 & 12.7 & 6.6 & 5.8 & $\mathrm{BDL}$ \\
\hline Iron $(\mathrm{mg} / \mathrm{L})$ & 0.15 & 0.09 & 0.11 & 0.07 & 1.86 & 3.06 & 1.10 & 0.26 & 6.22 \\
\hline $\begin{array}{l}\text { Calcium } \\
\text { (mg/L as } \\
\left.\mathrm{CaCO}_{3}\right)\end{array}$ & 22.5 & 17.0 & 19.6 & 14.4 & 4.90 & 48.6 & 48.2 & 24.8 & 79.4 \\
\hline $\begin{array}{c}\text { Total } \\
\text { Hardness } \\
(\mathrm{mg} / \mathrm{L} \text { as } \\
\left.\mathrm{CaCO}_{3}\right)\end{array}$ & 31.9 & 24.2 & 23.4 & 22.0 & 74.6 & 81.0 & 70.4 & 36.4 & ** \\
\hline $\begin{array}{l}\text { Nitrate } \\
(\mathrm{mg} / \mathrm{L})\end{array}$ & 0.40 & 0.49 & 0.50 & 0.47 & 0.21 & 0.22 & 0.20 & 0.46 & $\mathrm{BDL}$ \\
\hline $\begin{array}{l}\text { Nitrite } \\
\text { (mg/L) }\end{array}$ & BDL & $\mathrm{BDL}$ & $\mathrm{BDL}$ & BDL & BDL & BDL & BDL & BDL & $\mathrm{BDL}$ \\
\hline $\begin{array}{c}\text { Ammonia } \\
(\mathrm{mg} / \mathrm{L})\end{array}$ & 0.01 & $\mathrm{BDL}$ & BDL & BDL & 0.07 & 0.08 & 0.05 & 0.02 & BDL \\
\hline $\begin{array}{c}\text { Phosphate } \\
\text { (mg/L) }\end{array}$ & 0.06 & 0.03 & BDL & 0.05 & 0.02 & BDL & 0.01 & 0.01 & 0.05 \\
\hline $\begin{array}{c}\text { Manganese } \\
(\mathbf{m g} / \mathbf{L})\end{array}$ & 0.23 & 0.19 & BDL & 0.16 & 0.60 & 1.64 & 0.47 & BDL & 2.59 \\
\hline $\begin{array}{c}\text { Aluminum } \\
(\mathrm{mg} / \mathrm{L})\end{array}$ & 0.39 & 0.88 & BDL & 0.79 & 0.18 & 0.63 & 0.11 & BDL & 2.36 \\
\hline $\begin{array}{c}\text { Magnesium } \\
(\mathrm{mg} / \mathrm{L})\end{array}$ & 2.56 & 1.41 & 0.61 & 1.3 & 4.44 & 5.71 & 4.40 & 2.63 & 13.3 \\
\hline
\end{tabular}

** presence of interfering species in water sample.

-- starting $\mathrm{pH}<4.3$, methyl orange indicator titrametric endpoint.

$\mathrm{BDL}=$ below detection limit (presented previously in Table 3.2.) 
Comparing the data from the water quality analyses with criteria presented previously in Table 4.1, five parameters exceed the limits specified: $\mathrm{pH}$, iron concentration, conductivity, manganese concentration, and aluminum concentration.

\subsubsection{Lower Laurel Run, September 26, 2000}

The parameters sampled at Lower Laurel Run were within the given limits of Table 4.1, except for the aluminum concentration, which was $0.39 \mathrm{mg} / \mathrm{L}$. Turbidity was 10.1 NTU and total suspended solids concentration was $17.4 \mathrm{mg} / \mathrm{L}$. Alkalinity and acidity were $20.5 \mathrm{mg} / \mathrm{L}$ as $\mathrm{CaCO}_{3}$ and $1.80 \mathrm{mg} / \mathrm{L}$ as $\mathrm{CaCO}_{3}$, respectively. Conductivity was $96.7 \mu \mathrm{S} / \mathrm{cm}$ and $\mathrm{pH}$ was 7.15 . Sulfate, iron, and chloride concentrations were 27.2 $\mathrm{mg} / \mathrm{L}, 0.15 \mathrm{mg} / \mathrm{L}$, and $4.6 \mathrm{mg} / \mathrm{L}$, respectively. Manganese concentration was $0.23 \mathrm{mg} / \mathrm{L}$. Calcium was $22.5 \mathrm{mg} / \mathrm{L}$ as $\mathrm{CaCO}_{3}$, magnesium was $2.56 \mathrm{mg} / \mathrm{L}$, and total hardness was $31.9 \mathrm{mg} / \mathrm{L}$ as $\mathrm{CaCO}_{3}$. Nitrate concentration was $0.40 \mathrm{mg} / \mathrm{L}$, ammonia concentration was

$0.01 \mathrm{mg} / \mathrm{L}$, and phosphate concentration was $0.06 \mathrm{mg} / \mathrm{L}$. Nitrite concentration was below detection limit.

Flow was measured as $3.63 \mathrm{~m}^{3} / \mathrm{s}$. Particle size distribution is presented in Figure 4.17. The mean particle diameter for Lower Laurel Run, Site 1, was $67.8 \mu \mathrm{m}$. 


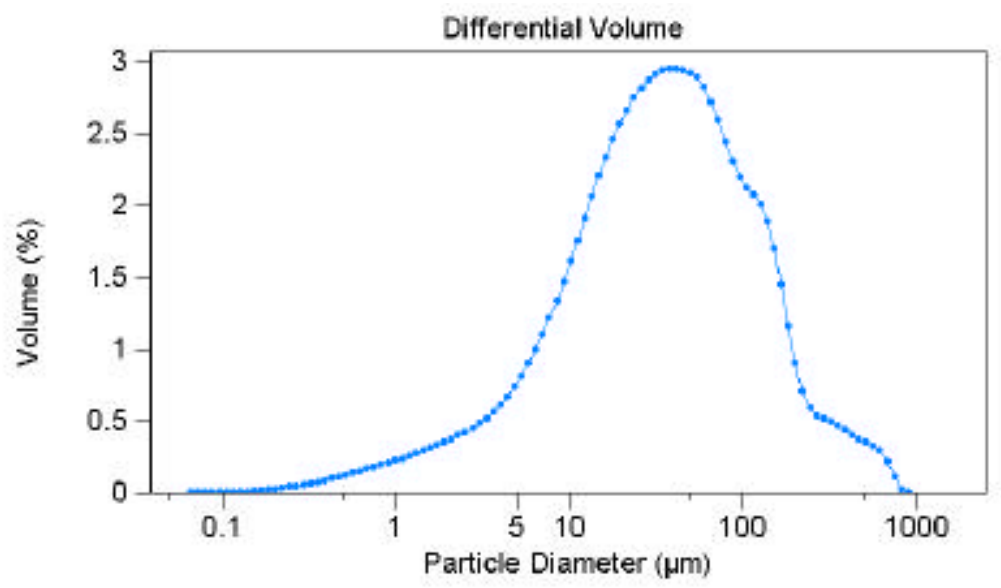

Figure 4.17. Particle Size Distribution for Lower Laurel Run (Site 1), September 26, 2000.

\subsubsection{The Box Culvert, September 26, 2000}

The water quality parameters at Site 2 were within the limits specified previously in Table 4.1, with the exception of aluminum concentration and $\mathrm{pH}$. The $\mathrm{pH}$ was 5.89, which was below the range designated previously in Table 4.1. Turbidity and total suspended solids concentration were $37.6 \mathrm{NTU}$ and $25.4 \mathrm{mg} / \mathrm{L}$, respectively. Conductivity was $74.2 \mu \mathrm{S} / \mathrm{cm}$. Acidity was $3.92 \mathrm{mg} / \mathrm{L}$ as $\mathrm{CaCO}_{3}$ and alkalinity was 15.0 $\mathrm{mg} / \mathrm{L}$ as $\mathrm{CaCO}_{3}$. Sulfate, iron, and chloride concentrations were $23.4 \mathrm{mg} / \mathrm{L}, 0.09 \mathrm{mg} / \mathrm{L}$, and $1.2 \mathrm{mg} / \mathrm{L}$. Aluminum was $0.88 \mathrm{mg} / \mathrm{L}$ and manganese was $0.19 \mathrm{mg} / \mathrm{L}$. Calcium was $17.0 \mathrm{mg} / \mathrm{L}$ as $\mathrm{CaCO}_{3}$, magnesium was $1.41 \mathrm{mg} / \mathrm{L}$, and total hardness was $24.2 \mathrm{mg} / \mathrm{L}$ as $\mathrm{CaCO}_{3}$. Nitrate concentration was $0.49 \mathrm{mg} / \mathrm{L}$, and phosphate concentration was 0.03 $\mathrm{mg} / \mathrm{L}$. Nitrite concentration and ammonia concentration were below the detection limits.

Flow was not measured, as insufficient water was present to fill the flow meter conduit. Particle size distribution is presented in Figure 4.18. The mean particle diameter for the box culvert, Site 2, was $44.6 \mu \mathrm{m}$. 


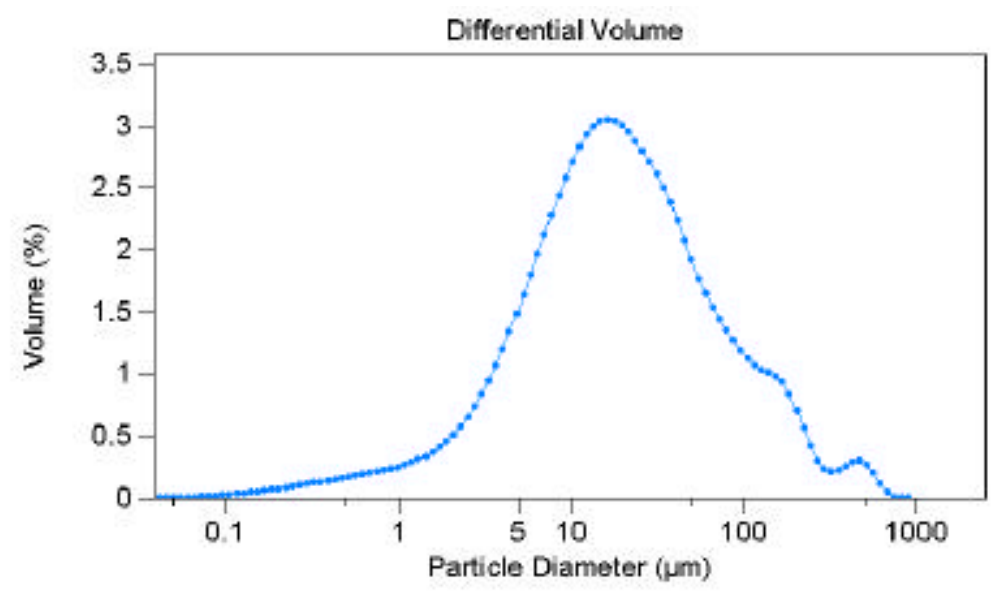

Figure 4.18. Particle Size Distribution for the Box Culvert (Site 2), September 26, 2000.

\subsubsection{Above the Spoils Pile, September 26, 2000}

All the parameters evaluated at the site above the spoils pile were within the limits previously specified in Table 4.1. The chloride, ammonia, nitrite, phosphate, aluminum, and manganese concentrations were below the detection limits. Turbidity, $\mathrm{pH}$, and conductivity were $17.0 \mathrm{NTU}, 6.75$, and $46.0 \mu \mathrm{S} / \mathrm{cm}$, respectively. Total suspended solids concentration was $15.8 \mathrm{mg} / \mathrm{L}$. Alkalinity was $20.3 \mathrm{mg} / \mathrm{L}$ as $\mathrm{CaCO}_{3}$ and acidity was 2.22 $\mathrm{mg} / \mathrm{L}$ as $\mathrm{CaCO}_{3}$. Sulfate was $5.80 \mathrm{mg} / \mathrm{L}$ and iron was $0.11 \mathrm{mg} / \mathrm{L}$. Calcium was 19.6 $\mathrm{mg} / \mathrm{L}$ as $\mathrm{CaCO}_{3}$, total hardness was $23.4 \mathrm{mg} / \mathrm{L}$ as $\mathrm{CaCO}_{3}$, and magnesium was 0.61 $\mathrm{mg} / \mathrm{L}$. Nitrate concentration was $0.50 \mathrm{mg} / \mathrm{L}$.

Flow was measured as $0.339 \mathrm{~m}^{3} / \mathrm{s}$. Particle size distribution is presented in Figure 4.19 . The mean particle diameter above the spoils pile, Site 2a, was $85.2 \mu \mathrm{m}$. 


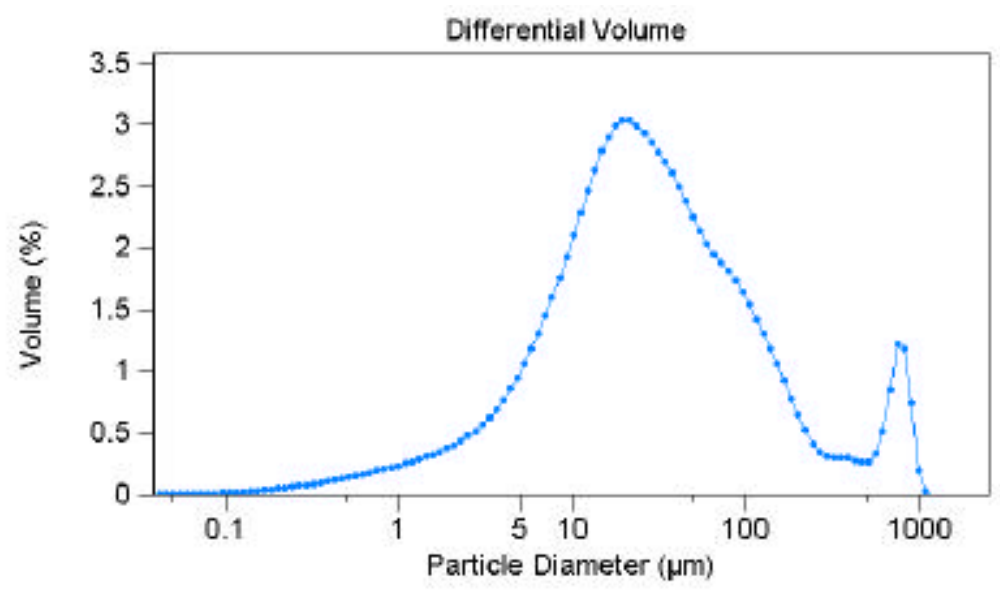

Figure 4.19. Particle Size Distribution for Above the Spoils Pile (Site 2a), September 26, 2000.

\subsubsection{Below the Spoils Pile, September 26, 2000}

The $\mathrm{pH}$ and the aluminum concentrations exceeded the limits set previously in Table 4.1 at the site sampled below the spoils pile. Aluminum concentration was 0.79 $\mathrm{mg} / \mathrm{L}$ and $\mathrm{pH}$ was 6.07. The other parameters examined were within the specified limits. Turbidity was 19.2 NTU and conductivity was $69.3 \mu \mathrm{S} / \mathrm{cm}$. Total suspended solids concentration was $23.5 \mathrm{mg} / \mathrm{L}$. Alkalinity and acidity were $15.1 \mathrm{mg} / \mathrm{L}$ as $\mathrm{CaCO}_{3}$ and 4.04 $\mathrm{mg} / \mathrm{L}$ as $\mathrm{CaCO}_{3}$, respectively. The chloride concentration was below the detection limit of $1.0 \mathrm{mg} / \mathrm{L}$. Sulfate concentration was $19.0 \mathrm{mg} / \mathrm{L}$ and iron concentration was $0.07 \mathrm{mg} / \mathrm{L}$. Manganese concentration was $0.16 \mathrm{mg} / \mathrm{L}$. Calcium was $14.4 \mathrm{mg} / \mathrm{L}$ as $\mathrm{CaCO}_{3}$, total hardness was $22.0 \mathrm{mg} / \mathrm{L}$ as $\mathrm{CaCO}_{3}$, and magnesium was $1.3 \mathrm{mg} / \mathrm{L}$. Nitrate concentration was $0.47 \mathrm{mg} / \mathrm{L}$ and phosphate concentration was $0.05 \mathrm{mg} / \mathrm{L}$. Nitrite and ammonia concentrations were below detection limits. 
Flow was not measured, as insufficient water was present to fill the flow meter conduit. Particle size distribution is presented in Figure 4.20. The mean particle diameter below the spoils pile, Site $2 \mathrm{~b}$, was $42.1 \mu \mathrm{m}$.

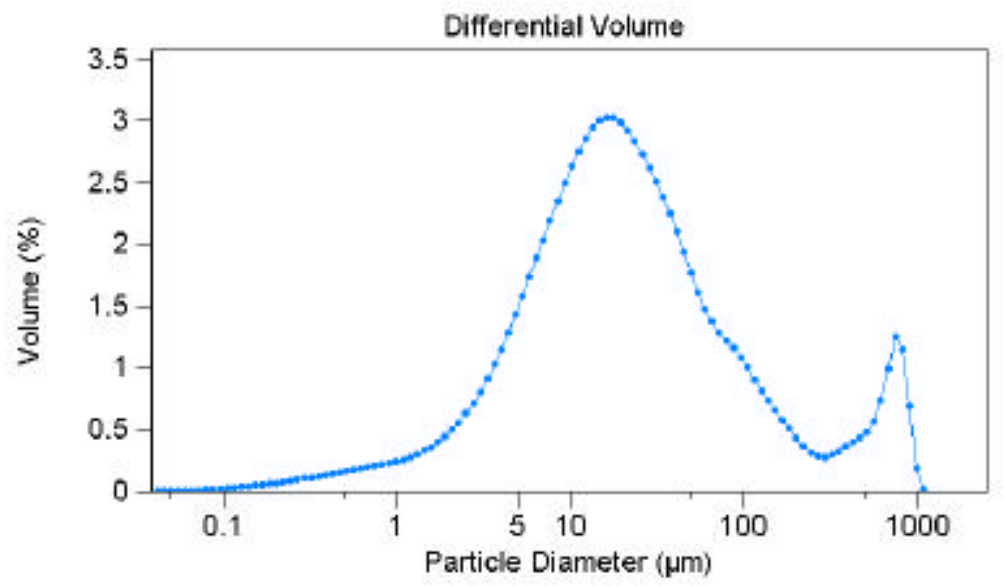

Figure 4.20. Particle Size Distribution Below the Spoils Pile (Site 2b), September 26, 2000.

\subsubsection{Middle Laurel Run, September 26, 2000}

Middle Laurel Run is a connector site for the station below the sedimentation pond and Laurel Run. At Site 3, aluminum and iron concentrations exceeded, and the $\mathrm{pH}$ was below the limits specified previously in Table 4.1; the other parameters were within acceptable limits. Turbidity was $6.62 \mathrm{NTU}$ and total suspended solids concentration was $6.27 \mathrm{mg} / \mathrm{L}$. pH was 6.30. Alkalinity and acidity were $19.8 \mathrm{mg} / \mathrm{L}$ as $\mathrm{CaCO}_{3}$ and 8.32 $\mathrm{mg} / \mathrm{L}$ as $\mathrm{CaCO}_{3}$, respectively. Conductivity was $187 \mu \mathrm{S} / \mathrm{cm}$, sulfate concentration was $54.5 \mathrm{mg} / \mathrm{L}$, iron concentration was $1.86 \mathrm{mg} / \mathrm{L}$, and chloride concentration was $6.9 \mathrm{mg} / \mathrm{L}$. Aluminum and manganese concentrations were $0.18 \mathrm{mg} / \mathrm{L}$ and $4.44 \mathrm{mg} / \mathrm{L}$, respectively. Calcium was $4.90 \mathrm{mg} / \mathrm{L}$ as $\mathrm{CaCO}_{3}$, total hardness was $74.6 \mathrm{mg} / \mathrm{L}$ as $\mathrm{CaCO}_{3}$, and magnesium was $4.44 \mathrm{mg} / \mathrm{L}$. Nitrate concentration was $0.21 \mathrm{mg} / \mathrm{L}$, ammonia 
concentration was $0.07 \mathrm{mg} / \mathrm{L}$, and phosphate concentration was $0.02 \mathrm{mg} / \mathrm{L}$. Nitrite concentration was below the detection limit.

Flow was not measured, as insufficient water was present to fill the flow meter conduit. Particle size distribution for Middle Laurel Run is presented in Figure 4.21. Particle size analysis was performed on the sample collected at Middle Laurel Run and the mean particle diameter was $22.3 \mu \mathrm{m}$.

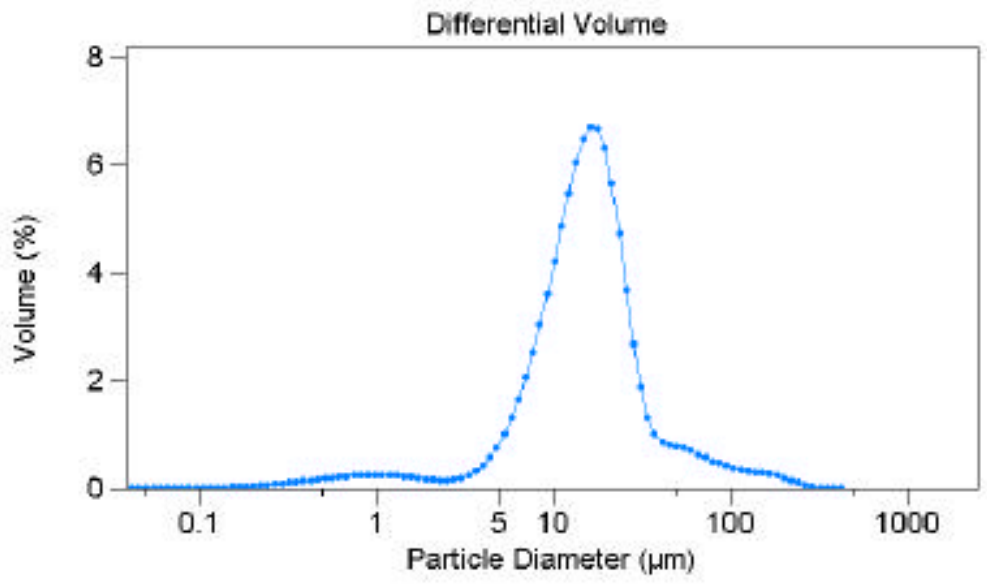

Figure 4.21. Particle Size Distribution for Middle Laurel Run (Site 3), September 26, 2000.

\subsubsection{Above the Sedimentation Pond, September 26, 2000}

With the exception of $\mathrm{pH}$, iron concentration, manganese concentration, and aluminum concentration, the parameters evaluated above the sedimentation pond were within the limits specified previously in Table 4.1. Turbidity was 34.8 NTU and total suspended solids concentration was $58.9 \mathrm{mg} / \mathrm{L}$. The $\mathrm{pH}$ was 6.32 . Alkalinity and acidity were $23.4 \mathrm{mg} / \mathrm{L}$ as $\mathrm{CaCO}_{3}$ and $9.76 \mathrm{mg} / \mathrm{L}$ as $\mathrm{CaCO}_{3}$, respectively. Conductivity was 174 $\mu \mathrm{S} / \mathrm{cm}$, the iron concentration was $3.06 \mathrm{mg} / \mathrm{L}$, sulfate concentration was $54.0 \mathrm{mg} / \mathrm{L}$, and chloride concentration was $12.7 \mathrm{mg} / \mathrm{L}$. Manganese concentration was $1.64 \mathrm{mg} / \mathrm{L}$ and the 
aluminum concentration was $0.63 \mathrm{mg} / \mathrm{L}$. Calcium was $48.6 \mathrm{mg} / \mathrm{L}$ as $\mathrm{CaCO}_{3}$, total hardness was $81.0 \mathrm{mg} / \mathrm{L}$ as $\mathrm{CaCO}_{3}$, and magnesium was $5.71 \mathrm{mg} / \mathrm{L}$. Nitrate concentration was $0.22 \mathrm{mg} / \mathrm{L}$ and ammonia concentration was $0.08 \mathrm{mg} / \mathrm{L}$, and nitrite and phosphate concentrations were below detection limits.

Particle size distribution for the site above the sedimentation pond is presented in Figure 4.22. The mean particle diameter above the sedimentation pond was $36.7 \mu \mathrm{m}$.

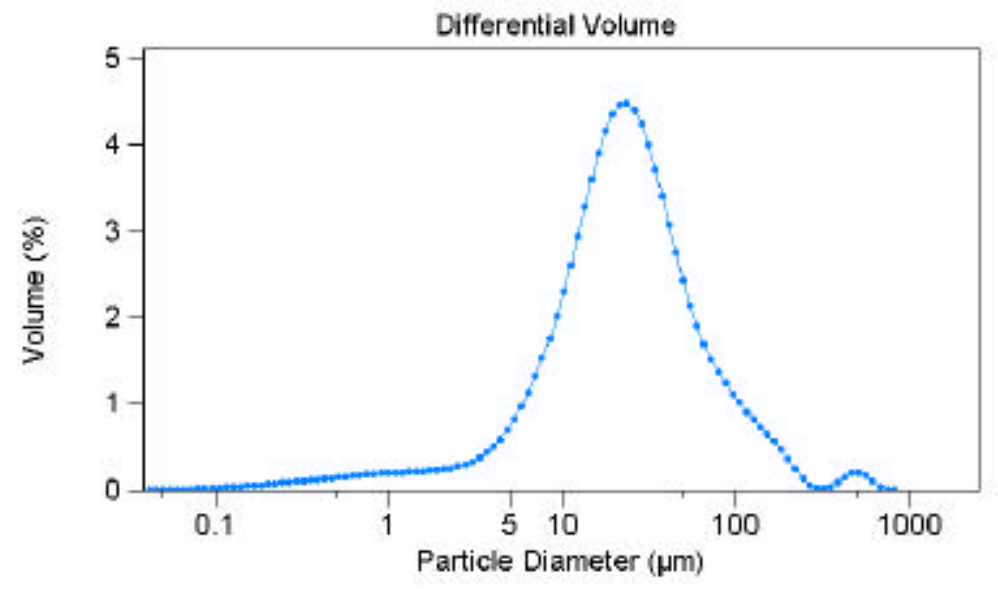

Figure 4.22. Particle Size Distribution for Above the Sedimentation Pond (Site 3a), September 26, 2000.

\subsubsection{Below the Sedimentation Pond, September 26, 2000}

At the site below the sedimentation pond, the water quality parameters were within the limits specified previously in Table 4.1 with the exception of aluminum and pH. Turbidity was $7.75 \mathrm{NTU}$ and total suspended solids concentration was $8.00 \mathrm{mg} / \mathrm{L}$. $\mathrm{pH}$ was 6.43. Alkalinity was $20.9 \mathrm{mg} / \mathrm{L}$ as $\mathrm{CaCO}_{3}$ and acidity was $7.38 \mathrm{mg} / \mathrm{L}$ as $\mathrm{CaCO}_{3}$. Conductivity was $185 \mu \mathrm{S} / \mathrm{cm}$. Sulfate was $53.0 \mathrm{mg} / \mathrm{L}$, chloride was $6.6 \mathrm{mg} / \mathrm{L}$, and iron concentration was $1.10 \mathrm{mg} / \mathrm{L}$. Manganese concentration was $0.47 \mathrm{mg} / \mathrm{L}$ and aluminum concentration was $0.11 \mathrm{mg} / \mathrm{L}$. Calcium was $48.2 \mathrm{mg} / \mathrm{L}$ as $\mathrm{CaCO}_{3}$, total hardness was 
$70.4 \mathrm{mg} / \mathrm{L}$ as $\mathrm{CaCO}_{3}$, and magnesium was $4.40 \mathrm{mg} / \mathrm{L}$. Nitrate concentration was 0.20 $\mathrm{mg} / \mathrm{L}$, ammonia concentration was $0.05 \mathrm{mg} / \mathrm{L}$, phosphate concentration was $0.01 \mathrm{mg} / \mathrm{L}$, and nitrite concentration was below detection limit.

Flow was not measured, as insufficient water was present to fill the flow meter conduit. Particle size analysis was performed on the sample collected at this site; however the particle concentration was not large enough to detect.

\subsubsection{Upper Laurel Run, September 26, 2000}

The results of the water quality analyses performed on the sample collected at Upper Laurel Run demonstrated that all the parameters were within the limits previously identified in Table 4.1. Turbidity was 6.08 NTU and total suspended solids concentration was $4.35 \mathrm{mg} / \mathrm{L}$. pH was 6.77 . Alkalinity was $25.1 \mathrm{mg} / \mathrm{L}$ as $\mathrm{CaCO}_{3}$ and acidity was 2.92 $\mathrm{mg} / \mathrm{L}$ as $\mathrm{CaCO}_{3}$. Conductivity was $108 \mu \mathrm{S} / \mathrm{cm}$, sulfate concentration was $19.4 \mathrm{mg} / \mathrm{L}$, iron concentration was $0.26 \mathrm{mg} / \mathrm{L}$, and chloride concentration was $5.8 \mathrm{mg} / \mathrm{L}$. Manganese and aluminum concentrations were below detection limits. Calcium, total hardness, and magnesium were $24.8 \mathrm{mg} / \mathrm{L}$ as $\mathrm{CaCO}_{3}, 36.4 \mathrm{mg} / \mathrm{L}$ as $\mathrm{CaCO}_{3}$, and $2.63 \mathrm{mg} / \mathrm{L}$, respectively. Nitrate concentration was $0.46 \mathrm{mg} / \mathrm{L}$ and ammonia and phosphate concentrations were $0.02 \mathrm{mg} / \mathrm{L}$ and $0.01 \mathrm{mg} / \mathrm{L}$ respectively. Nitrite concentration was below the detection limit.

Flow was not measured, as insufficient water was present to fill the flow meter conduit. Particle size analysis was performed on the sample collected at this site; however the particle concentration was not large enough to detect. 


\subsubsection{The Bench Drainage, September 26, 2000}

With the exception of five parameters $(\mathrm{pH}$, conductivity, iron concentration, manganese concentration, and aluminum concentration) the water quality data were within the limits specified previously in Table 4.1. Turbidity was 0.46 NTU and total suspended solids concentration was $0.45 \mathrm{mg} / \mathrm{L}$. The $\mathrm{pH}$ was 3.5. Alkalinity could not be determined because the starting $\mathrm{pH}$ was below the methyl orange indicator titrametric endpoint, 4.3. The acidity was $54.1 \mathrm{mg} / \mathrm{L}$ as $\mathrm{CaCO}_{3}$. Conductivity was $514 \mu \mathrm{S} / \mathrm{cm}$, sulfate concentration was $163 \mathrm{mg} / \mathrm{L}$, iron concentration was $6.22 \mathrm{mg} / \mathrm{L}$, manganese concentration was $2.59 \mathrm{mg} / \mathrm{L}$, and aluminum concentration was $2.36 \mathrm{mg} / \mathrm{L}$. The chloride concentration, the nitrate concentration, the nitrite concentration, and the ammonia concentration were below detection limits. Calcium was $79.4 \mathrm{mg} / \mathrm{L}$ as $\mathrm{CaCO}_{3}$ and magnesium was $13.3 \mathrm{mg} / \mathrm{L}$. The total hardness could not be determined due to an interfering species present in the water sample. Phosphate concentration was $0.05 \mathrm{mg} / \mathrm{L}$.

Flow was not measured, as insufficient water was present to fill the flow meter conduit. Particle size analysis was performed on the sample collected at this site; however the particle concentration was not large enough to detect.

\subsection{SAMPLING TRIP 6, NOVEMBER 12, 2000}

On November 12, 2000, an additional sample was taken at each site as identified in Figure 3.1. The results of the water quality analyses performed for the samples collected on November 12, 2000 are presented in Table 4.8 . 
Table 4.8. Results of Water Quality Analyses for November 12, 2000.

\begin{tabular}{|c|c|c|c|c|c|c|c|c|c|}
\hline & Site 1 & Site 2 & $\begin{array}{c}\text { Site } \\
\text { 2a }\end{array}$ & $\begin{array}{l}\text { Site } \\
\text { 2b }\end{array}$ & Site 3 & $\begin{array}{c}\text { Site } \\
\text { 3a }\end{array}$ & $\begin{array}{c}\text { Site } \\
\text { 3b }\end{array}$ & Site 4 & Site 5 \\
\hline $\begin{array}{c}\text { Turbidity } \\
\text { (NTU) }\end{array}$ & 0.68 & 9.09 & 2.61 & N/A & 17.90 & 14.60 & 20.90 & 3.85 & 0.23 \\
\hline pH & 7.09 & 6.66 & 7.07 & N/A & 6.79 & 6.12 & 6.70 & 6.78 & 3.38 \\
\hline $\begin{array}{c}\text { Conductivity } \\
(\mu \mathrm{S} / \mathrm{cm})\end{array}$ & 179.3 & 86.9 & 51.4 & N/A & 554 & 53.1 & 496.0 & 78.2 & 467.0 \\
\hline TSS (mg/L) & 0.48 & 4.55 & 2.35 & N/A & 4.45 & 2.13 & 16.9 & 0.65 & 0.60 \\
\hline $\begin{array}{c}\text { Alkalinity } \\
\text { (mg/L as } \\
\left.\mathrm{CaCO}_{3}\right)\end{array}$ & 24.5 & 20.7 & 29.5 & N/A & 38.4 & 82.2 & 40.4 & 33.3 & -- \\
\hline $\begin{array}{c}\text { Acidity } \\
(\mathrm{mg} / \mathrm{L} \text { as } \\
\left.\mathrm{CaCO}_{3}\right)\end{array}$ & 2.19 & 3.04 & 2.74 & N/A & 10.6 & 131.8 & 13.3 & 6.06 & 72.6 \\
\hline $\begin{array}{l}\text { Sulfate } \\
(\mathrm{mg} / \mathrm{L})\end{array}$ & 51.9 & 34.9 & 6.51 & N/A & 267 & 201 & 246 & 39.1 & 252 \\
\hline $\begin{array}{c}\text { Chloride } \\
\text { (mg/L) }\end{array}$ & 15.0 & 2.1 & 1.3 & N/A & 52.2 & 45.6 & 51.6 & 16.0 & BDL \\
\hline Iron $(\mathrm{mg} / \mathrm{L})$ & 0.19 & 0.19 & 0.06 & N/A & 1.48 & 25.0 & 1.61 & 0.66 & 6.73 \\
\hline $\begin{array}{l}\text { Calcium } \\
(\mathrm{mg} / \mathrm{L} \text { as } \\
\left.\mathrm{CaCO}_{3}\right)\end{array}$ & 42.9 & 21.6 & 15.6 & N/A & 160 & 132 & 156 & 37.6 & 112 \\
\hline $\begin{array}{c}\text { Total } \\
\text { Hardness } \\
(\mathrm{mg} / \mathrm{L} \text { as } \\
\left.\mathrm{CaCO}_{3}\right)\end{array}$ & 65.1 & 33.2 & 20.2 & N/A & 252 & $* *$ & 246 & 57.4 & 200 \\
\hline $\begin{array}{l}\text { Nitrate } \\
(\mathrm{mg} / \mathrm{L})\end{array}$ & 0.12 & 0.10 & 0.11 & N/A & 0.08 & BDL & 0.09 & 0.10 & 0.04 \\
\hline $\begin{array}{l}\text { Nitrite } \\
(\mathrm{mg} / \mathrm{L})\end{array}$ & BDL & BDL & BDL & N/A & BDL & $\mathrm{BDL}$ & BDL & $\mathrm{BDL}$ & BDL \\
\hline$\underset{(\mathrm{mg} / \mathrm{L})}{\operatorname{Ammonia}}$ & $\mathrm{BDL}$ & BDL & BDL & N/A & 0.60 & 0.84 & 0.59 & 0.02 & 0.02 \\
\hline $\begin{array}{c}\text { Phosphate } \\
\text { (mg/L) }\end{array}$ & 0.02 & 0.03 & 0.02 & N/A & 0.01 & 0.01 & 0.01 & $\mathrm{BDL}$ & BDL \\
\hline $\begin{array}{c}\text { Manganese } \\
(\mathrm{mg} / \mathrm{L})\end{array}$ & 0.34 & 0.63 & BDL & N/A & 6.05 & 8.18 & 6.01 & 0.20 & 2.16 \\
\hline$\underset{(m g / L)}{\text { Aluminum }}$ & 0.12 & 0.46 & BDL & N/A & 0.11 & 0.13 & 0.11 & $\mathrm{BDL}$ & 2.44 \\
\hline $\begin{array}{c}\text { Magnesium } \\
(\mathrm{mg} / \mathrm{L})\end{array}$ & 4.88 & 7.71 & 1.01 & N/A & 17.4 & 20.0 & 18.3 & 4.70 & 17.1 \\
\hline
\end{tabular}

** presence of interfering species in water sample.

-- starting $\mathrm{pH}<4.3$, methyl orange indicator titrametric endpoint.

$\mathrm{BDL}=$ below detection limit (presented previously in Table 3.2.) 
Comparing the data from the water quality analyses with criteria presented previously in Table 4.1, five parameters exceed the limits specified: $\mathrm{pH}$, iron concentration, conductivity, manganese concentration, and aluminum concentration.

\subsubsection{Lower Laurel Run, November 12, 2000}

The parameters sampled at Lower Laurel Run were within the given limits of Table 4.1 with the exception of aluminum concentration, which was $0.12 \mathrm{mg} / \mathrm{L}$. Turbidity was $0.68 \mathrm{NTU}$ and total suspended solids concentration was $0.48 \mathrm{mg} / \mathrm{L}$. Alkalinity and acidity were $24.5 \mathrm{mg} / \mathrm{L}$ as $\mathrm{CaCO}_{3}$ and $2.19 \mathrm{mg} / \mathrm{L}$ as $\mathrm{CaCO}_{3}$, respectively. Conductivity was $179 \mu \mathrm{S} / \mathrm{cm}$ and $\mathrm{pH}$ was 7.15 . Sulfate, iron, and chloride concentrations were $51.9 \mathrm{mg} / \mathrm{L}, 0.19 \mathrm{mg} / \mathrm{L}$, and $15.0 \mathrm{mg} / \mathrm{L}$, respectively. Manganese concentration was $0.34 \mathrm{mg} / \mathrm{L}$. Calcium was $42.9 \mathrm{mg} / \mathrm{L}$ as $\mathrm{CaCO}_{3}$, magnesium was $4.88 \mathrm{mg} / \mathrm{L}$, and total hardness was $65.1 \mathrm{mg} / \mathrm{L}$ as $\mathrm{CaCO}_{3}$. Nitrate concentration was $0.12 \mathrm{mg} / \mathrm{L}$ and phosphate concentration was $0.02 \mathrm{mg} / \mathrm{L}$. Nitrite concentration and ammonia concentrations were below detection limit.

Flow was measured as $0.623 \mathrm{~m}^{3} / \mathrm{s}$. Particle size analysis was performed on the sample collected at this site; however the particle concentration was not large enough to detect.

\subsubsection{The Box Culvert, November 12, 2000}

The water quality parameters were within the limits specified previously in Table 4.1, with the exception of aluminum concentration. The $\mathrm{pH}$ was 6.66 . Turbidity and total suspended solids concentration were $9.09 \mathrm{NTU}$ and $4.55 \mathrm{mg} / \mathrm{L}$, respectively. 
Conductivity was $86.9 \mu \mathrm{S} / \mathrm{cm}$. Acidity was $3.04 \mathrm{mg} / \mathrm{L}$ as $\mathrm{CaCO}_{3}$ and alkalinity was 20.7 $\mathrm{mg} / \mathrm{L}$ as $\mathrm{CaCO}_{3}$. Sulfate, iron, and chloride concentrations were $34.9 \mathrm{mg} / \mathrm{L}, 0.19 \mathrm{mg} / \mathrm{L}$, and $2.1 \mathrm{mg} / \mathrm{L}$. Aluminum was $0.46 \mathrm{mg} / \mathrm{L}$ and manganese was $0.63 \mathrm{mg} / \mathrm{L}$. Calcium was $21.6 \mathrm{mg} / \mathrm{L}$ as $\mathrm{CaCO}_{3}$, magnesium was $7.71 \mathrm{mg} / \mathrm{L}$, and total hardness was $33.2 \mathrm{mg} / \mathrm{L}$ as $\mathrm{CaCO}_{3}$. Nitrate concentration was $0.10 \mathrm{mg} / \mathrm{L}$ and phosphate concentration was 0.03 $\mathrm{mg} / \mathrm{L}$. Nitrite concentration and ammonia concentration were below the detection limits.

Flow was not measured, as insufficient water was present to fill the flow meter conduit. Particle size analysis was performed on the sample collected at this site; however the particle concentration was not large enough to detect.

\subsubsection{Above the Spoils Pile, November 12, 2000}

All the parameters evaluated at the site above the spoils pile were within the limits previously specified in Table 4.1. Turbidity, $\mathrm{pH}$, and conductivity were $2.61 \mathrm{NTU}, 7.07$, and $51.4 \mu \mathrm{S} / \mathrm{cm}$, respectively. Total suspended solids concentration was $2.35 \mathrm{mg} / \mathrm{L}$. Alkalinity was $29.5 \mathrm{mg} / \mathrm{L}$ as $\mathrm{CaCO}_{3}$ and acidity was $2.74 \mathrm{mg} / \mathrm{L}$ as $\mathrm{CaCO}_{3}$. Sulfate was $6.51 \mathrm{mg} / \mathrm{L}$ and iron was $0.06 \mathrm{mg} / \mathrm{L}$. The chloride concentration was $1.3 \mathrm{mg} / \mathrm{L}$. Calcium was $15.6 \mathrm{mg} / \mathrm{L}$ as $\mathrm{CaCO}_{3}$, total hardness was $20.2 \mathrm{mg} / \mathrm{L}$ as $\mathrm{CaCO}_{3}$, and magnesium was $1.01 \mathrm{mg} / \mathrm{L}$. Nitrate concentration was $0.11 \mathrm{mg} / \mathrm{L}$ and the phosphate concentration was $0.02 \mathrm{mg} / \mathrm{L}$. Nitrite concentration, ammonia concentration, manganese concentration, and aluminum concentration were below detection limit.

Flow was not measured, as insufficient water was present to fill the flow meter conduit. Particle size analysis was performed on the sample collected at this site; however the particle concentration was not large enough to detect. 


\subsubsection{Below the Spoils Pile, November 12, 2000}

A water sample was not collected at this site due to the insufficient flow rate at this site.

\subsubsection{Middle Laurel Run, November 12, 2000}

Middle Laurel Run is a connector site for the station below the sedimentation pond and Laurel Run. At Site 3, the parameters were within the limits specified previously in Table 4.1 with the exception of conductivity, manganese concentration, and aluminum concentration. Turbidity was 17.9 NTU and total suspended solids concentration was $4.45 \mathrm{mg} / \mathrm{L}$. pH was 6.79 . Alkalinity and acidity were $38.4 \mathrm{mg} / \mathrm{L}$ as $\mathrm{CaCO}_{3}$ and $10.6 \mathrm{mg} / \mathrm{L}$ as $\mathrm{CaCO}_{3}$, respectively. Conductivity was $554 \mu \mathrm{S} / \mathrm{cm}$, sulfate concentration was $267 \mathrm{mg} / \mathrm{L}$, iron concentration was $1.48 \mathrm{mg} / \mathrm{L}$, and chloride concentration was $52.2 \mathrm{mg} / \mathrm{L}$. Aluminum and manganese concentrations were $0.11 \mathrm{mg} / \mathrm{L}$ and $6.05 \mathrm{mg} / \mathrm{L}$, respectively. Calcium was $160 \mathrm{mg} / \mathrm{L}$ as $\mathrm{CaCO}_{3}$, total hardness was 252 $\mathrm{mg} / \mathrm{L}$ as $\mathrm{CaCO}_{3}$, and magnesium was $17.4 \mathrm{mg} / \mathrm{L}$. Nitrate concentration was $0.08 \mathrm{mg} / \mathrm{L}$, ammonia concentration was $0.60 \mathrm{mg} / \mathrm{L}$, and phosphate concentration was $0.01 \mathrm{mg} / \mathrm{L}$. Nitrite concentration was below the detection limit.

Flow was not measured, as insufficient water was present to fill the flow meter conduit. Particle size distribution for Middle Laurel Run is presented in Figure 4.23. Particle size analysis was performed on the sample collected at Middle Laurel Run and the mean particle diameter was $8.66 \mu \mathrm{m}$. 


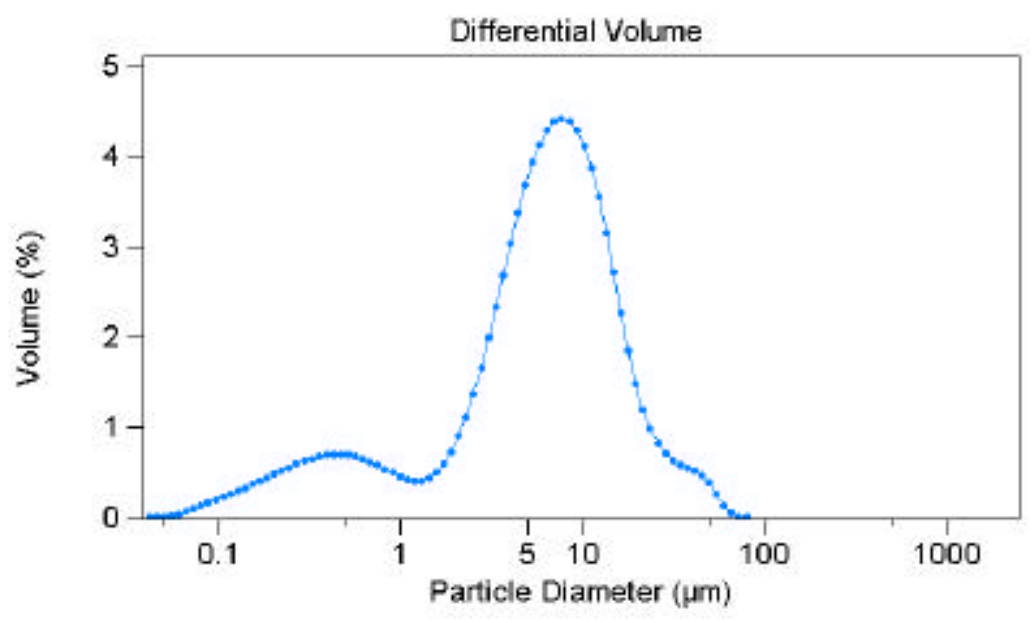

Figure 4.23. Particle Size Distribution for Middle Laurel Run (Site 3), November 12, 2000.

\subsubsection{Above the Sedimentation Pond, November 12, 2000}

With the exception of $\mathrm{pH}$, iron concentration, manganese concentration, and aluminum concentration, the parameters evaluated above the sedimentation pond were within the limits specified previously in Table 4.1. Turbidity was 14.6 NTU and total suspended solids concentration was $2.13 \mathrm{mg} / \mathrm{L}$. The $\mathrm{pH}$ was 6.12 . Alkalinity and acidity were $82.2 \mathrm{mg} / \mathrm{L}$ as $\mathrm{CaCO}_{3}$ and $132 \mathrm{mg} / \mathrm{L}$ as $\mathrm{CaCO}_{3}$, respectively. Conductivity was 53.1 $\mu \mathrm{S} / \mathrm{cm}$, the iron concentration was $25.0 \mathrm{mg} / \mathrm{L}$, sulfate concentration was $201 \mathrm{mg} / \mathrm{L}$, and chloride concentration was $45.6 \mathrm{mg} / \mathrm{L}$. Manganese concentration was $8.18 \mathrm{mg} / \mathrm{L}$ and the aluminum concentration was $0.13 \mathrm{mg} / \mathrm{L}$. Calcium was $132 \mathrm{mg} / \mathrm{L}$ as $\mathrm{CaCO}_{3}$, total hardness could not be determined due to interfering species in the sample, and magnesium was $20.0 \mathrm{mg} / \mathrm{L}$. Ammonia concentration was $0.84 \mathrm{mg} / \mathrm{L}$, and nitrite, nitrate, and phosphate concentrations were below detection limits. 
Flow was not measured, as insufficient water was present to fill the flow meter conduit. Particle size analysis was performed on the sample collected at this site; however the particle concentration was not large enough to detect.

\subsubsection{Below the Sedimentation Pond, November 12, 2000}

At the site below the sedimentation pond, the water quality parameters were within the limits specified previously in Table 4.1, with the exception of the iron, manganese, and aluminum. Turbidity was 20.9 NTU and total suspended solids concentration was $16.9 \mathrm{mg} / \mathrm{L}$. $\mathrm{pH}$ was 6.70 . Alkalinity was $40.4 \mathrm{mg} / \mathrm{L}$ as $\mathrm{CaCO}_{3}$ and acidity was $13.3 \mathrm{mg} / \mathrm{L}$ as $\mathrm{CaCO}_{3}$. Conductivity was $496 \mu \mathrm{S} / \mathrm{cm}$. Sulfate was $246 \mathrm{mg} / \mathrm{L}$, chloride was $51.6 \mathrm{mg} / \mathrm{L}$, and iron concentration was $1.61 \mathrm{mg} / \mathrm{L}$. Calcium was $156 \mathrm{mg} / \mathrm{L}$ as $\mathrm{CaCO}_{3}$, total hardness was $246 \mathrm{mg} / \mathrm{L}$ as $\mathrm{CaCO}_{3}$, and magnesium was $18.3 \mathrm{mg} / \mathrm{L}$. Nitrate concentration was $0.09 \mathrm{mg} / \mathrm{L}$, ammonia concentration was $0.59 \mathrm{mg} / \mathrm{L}$, phosphate concentration was $0.01 \mathrm{mg} / \mathrm{L}$, and nitrite concentration was below detection limit. Manganese concentration was $6.01 \mathrm{mg} / \mathrm{L}$ and aluminum concentration was $0.11 \mathrm{mg} / \mathrm{L}$.

Flow was not measured, as insufficient water was present to fill the flow meter conduit. Particle size distribution for the site below the sedimentation pond is presented in Figure 4.24. The mean particle diameter was at the site below the sedimentation pond was $15.8 \mu \mathrm{m}$. 


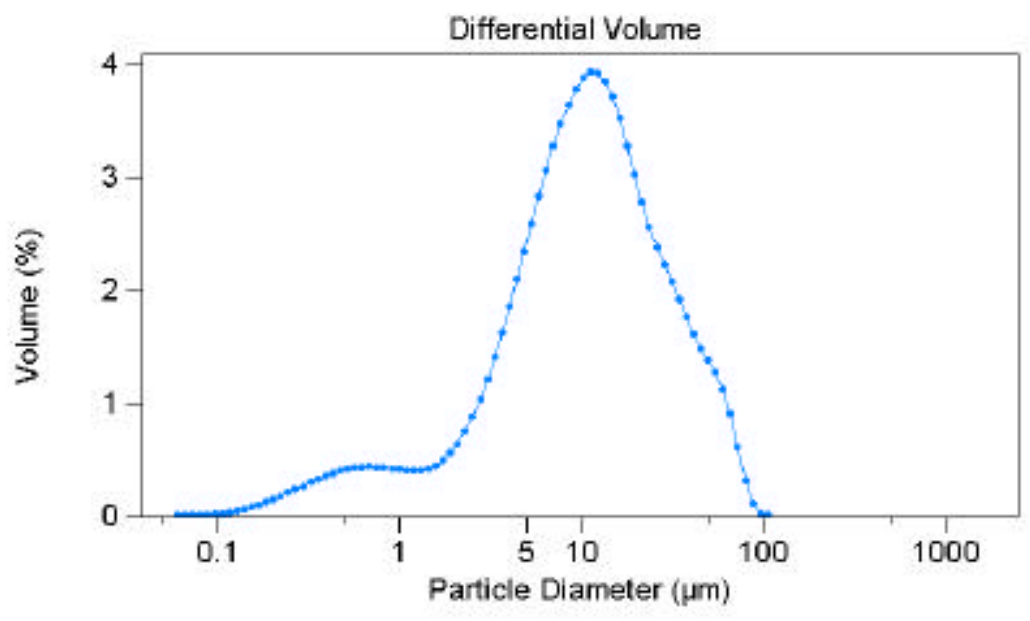

Figure 4.24. Particle Size Distribution for the Site Below the Sedimentation Pond (3b), November 12, 2000.

\subsubsection{Upper Laurel Run, November 12, 2000}

Through evaluation of the results of the water quality analyses performed on the sample collected at Upper Laurel Run it was determined that all the parameters were within the limits previously identified in Table 4.1. Turbidity was 3.85 NTU and total suspended solids concentration was $0.65 \mathrm{mg} / \mathrm{L}$. $\mathrm{pH}$ was 6.78 . Alkalinity was $33.3 \mathrm{mg} / \mathrm{L}$ as $\mathrm{CaCO}_{3}$ and acidity was $6.06 \mathrm{mg} / \mathrm{L}$ as $\mathrm{CaCO}_{3}$. Conductivity was $78.2 \mu \mathrm{S} / \mathrm{cm}$, sulfate concentration was $39.1 \mathrm{mg} / \mathrm{L}$, iron concentration was $0.66 \mathrm{mg} / \mathrm{L}$, and chloride concentration was $16.0 \mathrm{mg} / \mathrm{L}$. Calcium, total hardness, and magnesium were $37.6 \mathrm{mg} / \mathrm{L}$ as $\mathrm{CaCO}_{3}, 57.4 \mathrm{mg} / \mathrm{L}$ as $\mathrm{CaCO}_{3}$, and $4.70 \mathrm{mg} / \mathrm{L}$, respectively. Manganese concentration was $0.20 \mathrm{mg} / \mathrm{L}$. Aluminum concentration was below the detection limits. Nitrate concentration was $0.10 \mathrm{mg} / \mathrm{L}$ and ammonia concentration was $0.02 \mathrm{mg} / \mathrm{L}$. Nitrite and phosphate concentrations were below the detection limit.

Flow was not measured, as insufficient water was present to fill the flow meter conduit. Particle size analysis was performed on the sample collected at this site; however the particle concentration was not large enough to detect. 


\subsubsection{The Bench Drainage, November 12, 2000}

With the exception of four parameters $(\mathrm{pH}$, iron concentration, manganese concentration, and aluminum concentration) the water quality data was within the limits specified previously in Table 4.1. Turbidity was 0.23 NTU and total suspended solids concentration was $0.60 \mathrm{mg} / \mathrm{L}$. The $\mathrm{pH}$ was 3.38 . Alkalinity could not be determined because the sample $\mathrm{pH}$ was below the methyl orange indicator titrametric endpoint, 4.3. The acidity was $72.6 \mathrm{mg} / \mathrm{L}$ as $\mathrm{CaCO}_{3}$. Conductivity was $467 \mu \mathrm{S} / \mathrm{cm}$, sulfate concentration was $252 \mathrm{mg} / \mathrm{L}$, iron concentration was $6.73 \mathrm{mg} / \mathrm{L}$, manganese concentration was $2.16 \mathrm{mg} / \mathrm{L}$, and aluminum concentration was $2.44 \mathrm{mg} / \mathrm{L}$. The chloride concentration, the nitrite concentration, and the phosphate concentration were below detection limits. Calcium was $112 \mathrm{mg} / \mathrm{L}$ as $\mathrm{CaCO}_{3}$, total hardness was $200 \mathrm{mg} / \mathrm{L}$ as $\mathrm{CaCO}_{3}$, and magnesium was $17.1 \mathrm{mg} / \mathrm{L}$. Ammonia concentration was $0.02 \mathrm{mg} / \mathrm{L}$ and nitrate concentration $0.04 \mathrm{mg} / \mathrm{L}$.

Flow was not measured, as insufficient water was present to fill the flow meter conduit. Particle size analysis was performed on the sample collected at this site; however the particle concentration was not large enough to detect.

\subsection{SAMPLING TRIP 7, JANUARY 3, 2001}

On January 3, 2001, an additional sample was taken at each site as identified in Figure 3.1. The results of the water quality analyses performed for the samples collected on January 3, 2001 are presented in Table 4.9. 
Table 4.9. Results of Water Quality Analyses for January 3, 2001.

\begin{tabular}{|c|c|c|c|c|c|c|c|c|c|}
\hline & Site 1 & Site 2 & $\begin{array}{c}\text { Site } \\
\text { 2a }\end{array}$ & $\begin{array}{l}\text { Site } \\
\text { 2b }\end{array}$ & Site 3 & $\begin{array}{c}\text { Site } \\
\text { 3a }\end{array}$ & $\begin{array}{c}\text { Site } \\
\text { 3b }\end{array}$ & Site 4 & Site 5 \\
\hline $\begin{array}{c}\text { Turbidity } \\
\text { (NTU) }\end{array}$ & 1.99 & 3.45 & 7.98 & 2.44 & 5.91 & 6.09 & 5.22 & 2.85 & 6.33 \\
\hline pH & 6.05 & 5.97 & 6.44 & 5.14 & 6.25 & 6.15 & 6.07 & 6.34 & 3.18 \\
\hline $\begin{array}{c}\text { Conductivity } \\
(\mu \mathrm{S} / \mathrm{cm})\end{array}$ & 180 & 98.3 & 38.6 & 77.5 & 444 & 453 & 516 & 153 & 612 \\
\hline TSS (mg/L) & 2.30 & 5.12 & 8.00 & 3.65 & 10.1 & 11.3 & 9.25 & 1.50 & 34.4 \\
\hline $\begin{array}{c}\text { Alkalinity } \\
\text { (mg/L as } \\
\left.\mathrm{CaCO}_{3}\right)\end{array}$ & 5.22 & 3.29 & 7.96 & 1.28 & 17.7 & 19.9 & 34.9 & 10.1 & -- \\
\hline $\begin{array}{l}\text { Acidity } \\
\text { (mg/L as } \\
\left.\mathrm{CaCO}_{3}\right)\end{array}$ & 1.6 & 5.98 & 0.00 & 8.88 & 0.00 & 11.6 & 8.80 & 0.00 & 101 \\
\hline $\begin{array}{l}\text { Sulfate } \\
(\mathrm{mg} / \mathrm{L})\end{array}$ & 43.9 & 26.2 & 10.0 & 21.1 & 125 & 119 & 169 & 26.4 & 231 \\
\hline $\begin{array}{c}\text { Chloride } \\
\text { (mg/L) }\end{array}$ & 20.5 & 4.7 & 1.8 & 3.5 & 69.2 & 69.7 & 67.2 & 20.2 & $\mathrm{BDL}$ \\
\hline Iron $(\mathrm{mg} / \mathrm{L})$ & 0.25 & 0.10 & 0.10 & 0.10 & 10.4 & 11.4 & 25.4 & 1.42 & 18.2 \\
\hline $\begin{array}{l}\text { Calcium } \\
(\mathrm{mg} / \mathrm{L} \text { as } \\
\left.\mathrm{CaCO}_{3}\right)\end{array}$ & 17.8 & 10.7 & 4.7 & 8.03 & 44.3 & 45.3 & 57.1 & 14.0 & 45.0 \\
\hline $\begin{array}{c}\text { Total } \\
\text { Hardness } \\
(\mathrm{mg} / \mathrm{L} \text { as } \\
\left.\mathrm{CaCO}_{3}\right)\end{array}$ & 66.3 & 38.4 & 15.5 & 29.4 & 162 & 166 & 212 & 53.4 & 184 \\
\hline $\begin{array}{l}\text { Nitrate } \\
(\mathrm{mg} / \mathrm{L})\end{array}$ & 0.17 & 0.32 & 0.34 & 0.33 & 0.17 & 0.14 & 0.11 & 0.31 & BDL \\
\hline $\begin{array}{l}\text { Nitrite } \\
\text { (mg/L) }\end{array}$ & BDL & BDL & BDL & BDL & BDL & BDL & BDL & $\mathrm{BDL}$ & $\mathrm{BDL}$ \\
\hline $\begin{array}{c}\text { Ammonia } \\
(\mathrm{mg} / \mathrm{L})\end{array}$ & $\mathrm{BDL}$ & 0.03 & 0.06 & 0.04 & 0.48 & 0.67 & 0.44 & 0.02 & $\mathrm{BDL}$ \\
\hline $\begin{array}{c}\text { Phosphate } \\
\text { (mg/L) }\end{array}$ & $\mathrm{BDL}$ & BDL & BDL & BDL & BDL & BDL & BDL & $\mathrm{BDL}$ & $\mathrm{BDL}$ \\
\hline $\begin{array}{c}\text { Manganese } \\
(\mathrm{mg} / \mathrm{L})\end{array}$ & 0.45 & 0.74 & BDL & 0.56 & 4.89 & 4.69 & 7.81 & 0.42 & 2.25 \\
\hline$\underset{(m g / L)}{\text { Aluminum }}$ & 0.38 & 1.20 & BDL & 1.3 & 0.11 & 0.13 & 0.17 & 0.15 & 2.6 \\
\hline $\begin{array}{c}\text { Magnesium } \\
(\mathrm{mg} / \mathrm{L})\end{array}$ & 5.22 & 2.82 & 0.92 & 2.24 & 12.2 & 12.7 & 16.6 & 4.43 & 17.1 \\
\hline
\end{tabular}

** presence of interfering species in water sample.

-- starting $\mathrm{pH}<4.3$, methyl orange indicator titrametric endpoint.

$\mathrm{BDL}=$ below detection limit (presented previously in Table 3.2.) 
Comparing the data from the water quality analyses with criteria presented previously in Table 4.1, five parameters exceed the limits specified: $\mathrm{pH}$, iron concentration, conductivity, manganese concentration, and aluminum concentration.

\subsubsection{Lower Laurel Run, January 3, 2001}

The parameters sampled at Lower Laurel Run were within the given limits of Table 4.1 with the exception of aluminum concentration, which was $0.12 \mathrm{mg} / \mathrm{L}$ and $\mathrm{pH}$, which was 6.05 . Turbidity was 1.99 NTU and total suspended solids concentration was $2.30 \mathrm{mg} / \mathrm{L}$. Alkalinity and acidity were $5.22 \mathrm{mg} / \mathrm{L}$ as $\mathrm{CaCO}_{3}$ and $1.60 \mathrm{mg} / \mathrm{L}$ as $\mathrm{CaCO}_{3}$, respectively. Conductivity was $180 \mu \mathrm{S} / \mathrm{cm}$. Sulfate, iron, and chloride concentrations were $43.9 \mathrm{mg} / \mathrm{L}, 0.25 \mathrm{mg} / \mathrm{L}$, and $20.5 \mathrm{mg} / \mathrm{L}$, respectively. Manganese concentration was $0.45 \mathrm{mg} / \mathrm{L}$. Calcium was $17.8 \mathrm{mg} / \mathrm{L}$, magnesium was $5.22 \mathrm{mg} / \mathrm{L}$, and total hardness was $66.3 \mathrm{mg} / \mathrm{L}$ as $\mathrm{CaCO}_{3}$. Nitrate concentration was $0.17 \mathrm{mg} / \mathrm{L}$. Nitrite concentration, phosphate concentration, and ammonia concentrations were below detection limit.

Flow was not measured, as insufficient water was present to fill the flow meter conduit. Particle size analysis was performed on the sample collected at this site; however the particle concentration was not large enough to detect.

\subsubsection{The Box Culvert, January 3, 2001}

At Site 2, the water quality parameters were within the limits specified previously in Table 4.1, with the exception of aluminum concentration and the $\mathrm{pH}$, which was 5.97. Turbidity and total suspended solids concentration were $3.45 \mathrm{NTU}$ and $5.12 \mathrm{mg} / \mathrm{L}$, respectively. Conductivity was $98.3 \mu \mathrm{S} / \mathrm{cm}$. Acidity was $5.98 \mathrm{mg} / \mathrm{L}$ as $\mathrm{CaCO}_{3}$ and 
alkalinity was $3.29 \mathrm{mg} / \mathrm{L}$ as $\mathrm{CaCO}_{3}$. Sulfate, iron, and chloride concentrations were 26.2 $\mathrm{mg} / \mathrm{L}, 0.10 \mathrm{mg} / \mathrm{L}$, and $4.7 \mathrm{mg} / \mathrm{L}$. Aluminum was $1.20 \mathrm{mg} / \mathrm{L}$ and manganese was 0.74 mg/L. Calcium was $10.7 \mathrm{mg} / \mathrm{L}$, magnesium was $2.82 \mathrm{mg} / \mathrm{L}$, and total hardness was 38.4 $\mathrm{mg} / \mathrm{L}$ as $\mathrm{CaCO}_{3}$. Nitrate concentration was $0.32 \mathrm{mg} / \mathrm{L}$ and ammonia concentration was $0.03 \mathrm{mg} / \mathrm{L}$. Nitrite concentration and phosphate concentration were below the detection limits.

Flow was not measured, as insufficient water was present to fill the flow meter conduit. Particle size analysis was performed on the sample collected at this site; however the particle concentration was not large enough to detect.

\subsubsection{Above the Spoils Pile, January 3, 2001}

All the parameters evaluated at the site above the spoils pile were within the limits previously specified in Table 4.1 with the exception of $\mathrm{pH}$, which was 6.44 . Turbidity and conductivity were $7.98 \mathrm{NTU}$ and $38.6 \mu \mathrm{S} / \mathrm{cm}$, respectively. Total suspended solids concentration was $8.00 \mathrm{mg} / \mathrm{L}$. Alkalinity was $7.96 \mathrm{mg} / \mathrm{L}$ as $\mathrm{CaCO}_{3}$ and acidity was 0.00 $\mathrm{mg} / \mathrm{L}$ as $\mathrm{CaCO}_{3}$. Sulfate was $10.0 \mathrm{mg} / \mathrm{L}$ and iron was $0.10 \mathrm{mg} / \mathrm{L}$. The chloride concentration was $1.8 \mathrm{mg} / \mathrm{L}$. Calcium was $4.7 \mathrm{mg} / \mathrm{L}$, total hardness was $15.5 \mathrm{mg} / \mathrm{L}$ as $\mathrm{CaCO}_{3}$, and magnesium was $0.92 \mathrm{mg} / \mathrm{L}$. Nitrate concentration was $0.34 \mathrm{mg} / \mathrm{L}$ and the ammonia concentration was $0.06 \mathrm{mg} / \mathrm{L}$. Nitrite concentration, phosphate concentration, manganese concentration, and aluminum concentration were below detection limit.

Flow was not measured, as insufficient water was present to fill the flow meter conduit. Particle size analysis was performed on the sample collected at this site; however the particle concentration was not large enough to detect. 


\subsubsection{Below the Spoils Pile, January 3, 2001}

All the parameters evaluated at the site above the spoils pile were within the limits previously specified in Table 4.1 with the exception of $\mathrm{pH}$, which was 5.14 , and aluminum concentration, which was $1.3 \mathrm{mg} / \mathrm{L}$. Turbidity and conductivity were 2.44 NTU and $77.5 \mu \mathrm{S} / \mathrm{cm}$, respectively. Total suspended solids concentration was $3.65 \mathrm{mg} / \mathrm{L}$. Alkalinity was $1.28 \mathrm{mg} / \mathrm{L}$ as $\mathrm{CaCO}_{3}$ and acidity was $8.88 \mathrm{mg} / \mathrm{L}$ as $\mathrm{CaCO}_{3}$. Sulfate was $21.1 \mathrm{mg} / \mathrm{L}$ and iron was $0.10 \mathrm{mg} / \mathrm{L}$. The chloride concentration was $3.5 \mathrm{mg} / \mathrm{L}$. Manganese concentration was $0.56 \mathrm{mg} / \mathrm{L}$. Calcium was $8.03 \mathrm{mg} / \mathrm{L}$, total hardness was $29.4 \mathrm{mg} / \mathrm{L}$ as $\mathrm{CaCO}_{3}$, and magnesium was $2.24 \mathrm{mg} / \mathrm{L}$. Nitrate concentration was 0.33 $\mathrm{mg} / \mathrm{L}$ and the ammonia concentration was $0.04 \mathrm{mg} / \mathrm{L}$. Nitrite concentration and phosphate concentration were below detection limit.

Flow was not measured, as insufficient water was present to fill the flow meter conduit. Particle size analysis was performed on the sample collected at this site; however the particle concentration was not large enough to detect.

\subsubsection{Middle Laurel Run, January 3, 2001}

At Site 3, the parameters were within the limits specified previously in Table 4.1 with the exception of $\mathrm{pH}$, manganese concentration, iron concentration, and aluminum concentration. Turbidity was 5.91 NTU and total suspended solids concentration was $11.3 \mathrm{mg} / \mathrm{L}$. $\mathrm{pH}$ was 6.25 . Alkalinity and acidity were $17.7 \mathrm{mg} / \mathrm{L}$ as $\mathrm{CaCO}_{3}$ and 0.00 $\mathrm{mg} / \mathrm{L}$ as $\mathrm{CaCO}_{3}$, respectively. Conductivity was $444 \mu \mathrm{S} / \mathrm{cm}$, sulfate concentration was $125 \mathrm{mg} / \mathrm{L}$, iron concentration was $10.4 \mathrm{mg} / \mathrm{L}$, and chloride concentration was $69.2 \mathrm{mg} / \mathrm{L}$. Aluminum and manganese concentrations were $0.11 \mathrm{mg} / \mathrm{L}$ and $4.89 \mathrm{mg} / \mathrm{L}$, respectively. 
Calcium was $44.3 \mathrm{mg} / \mathrm{L}$, total hardness was $162 \mathrm{mg} / \mathrm{L}$ as $\mathrm{CaCO}_{3}$, and magnesium was $12.2 \mathrm{mg} / \mathrm{L}$. Nitrate concentration was $0.17 \mathrm{mg} / \mathrm{L}$ and ammonia concentration was 0.48 $\mathrm{mg} / \mathrm{L}$. Nitrite concentration and phosphate concentration were below the detection limit.

Flow was not measured, as insufficient water was present to fill the flow meter conduit. Particle size distribution for Middle Laurel Run is presented in Figure 4.25. Particle size analysis was performed on the sample collected at Middle Laurel Run and the mean particle diameter was $14.3 \mu \mathrm{m}$.

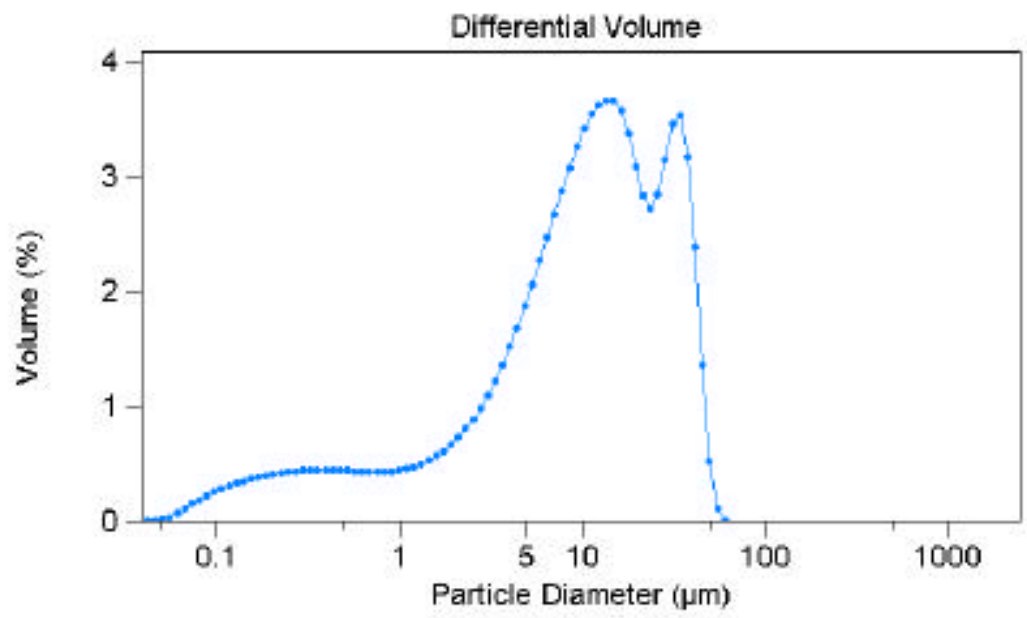

Figure 4.25. Particle Size Distribution for Middle Laurel Run (Site 3), January 3, 2001.

\subsubsection{Above the Sedimentation Pond, January 3, 2001}

With the exception of $\mathrm{pH}$, iron, manganese, and aluminum concentrations, the parameters evaluated above the sedimentation pond were within the limits specified previously in Table 4.1. Turbidity was 6.09 NTU and total suspended solids concentration was $11.3 \mathrm{mg} / \mathrm{L}$. The $\mathrm{pH}$ was 6.15 . Alkalinity and acidity were $19.9 \mathrm{mg} / \mathrm{L}$ as $\mathrm{CaCO}_{3}$ and $11.6 \mathrm{mg} / \mathrm{L}$ as $\mathrm{CaCO}_{3}$, respectively. Conductivity was $453 \mu \mathrm{S} / \mathrm{cm}$, the iron 
concentration was $11.4 \mathrm{mg} / \mathrm{L}$, sulfate concentration was $119 \mathrm{mg} / \mathrm{L}$, and chloride concentration was $69.7 \mathrm{mg} / \mathrm{L}$. Manganese concentration was $4.69 \mathrm{mg} / \mathrm{L}$ and the aluminum concentration was $0.13 \mathrm{mg} / \mathrm{L}$. Calcium was $45.3 \mathrm{mg} / \mathrm{L}$, total hardness was 166 $\mathrm{mg} / \mathrm{L}$ as $\mathrm{CaCO}_{3}$, and magnesium was $12.7 \mathrm{mg} / \mathrm{L}$. Ammonia concentration was 0.67 $\mathrm{mg} / \mathrm{L}$ and nitrate concentration was $0.14 \mathrm{mg} / \mathrm{L}$. Nitrite and phosphate concentrations were below detection limits.

Flow was not measured, as insufficient water was present to fill the flow meter conduit. Particle size analysis was performed on the sample collected at this site; however the particle concentration was not large enough to detect.

\subsubsection{Below the Sedimentation Pond, January 3, 2001}

At the site below the sedimentation pond, the water quality parameters were within the limits specified previously in Table 4.1, with the exception of the $\mathrm{pH}$, conductivity, iron, manganese, and aluminum concentrations. Turbidity was 5.22 NTU and total suspended solids concentration was $9.25 \mathrm{mg} / \mathrm{L}$. pH was 6.07. Alkalinity was $34.9 \mathrm{mg} / \mathrm{L}$ as $\mathrm{CaCO}_{3}$ and acidity was $8.80 \mathrm{mg} / \mathrm{L}$ as $\mathrm{CaCO}_{3}$. Conductivity was 516 $\mu \mathrm{S} / \mathrm{cm}$. Sulfate was $169 \mathrm{mg} / \mathrm{L}$, chloride was $67.2 \mathrm{mg} / \mathrm{L}$, and iron concentration was 25.4 $\mathrm{mg} / \mathrm{L}$. Manganese concentration was $7.81 \mathrm{mg} / \mathrm{L}$ and aluminum concentration was 0.17 $\mathrm{mg} / \mathrm{L}$. Calcium was $57.1 \mathrm{mg} / \mathrm{L}$, total hardness was $212 \mathrm{mg} / \mathrm{L}$ as $\mathrm{CaCO}_{3}$, and magnesium was $16.6 \mathrm{mg} / \mathrm{L}$. Nitrate concentration was $0.11 \mathrm{mg} / \mathrm{L}$ and ammonia concentration was $0.44 \mathrm{mg} / \mathrm{L}$. Phosphate concentration and nitrite concentration were below detection limits. 
Flow was not measured, as insufficient water was present to fill the flow meter conduit. Particle size distribution for the site below the sedimentation pond is presented in Figure 4.26. The mean particle diameter at Site $3 b$ was $14.8 \mu \mathrm{m}$.

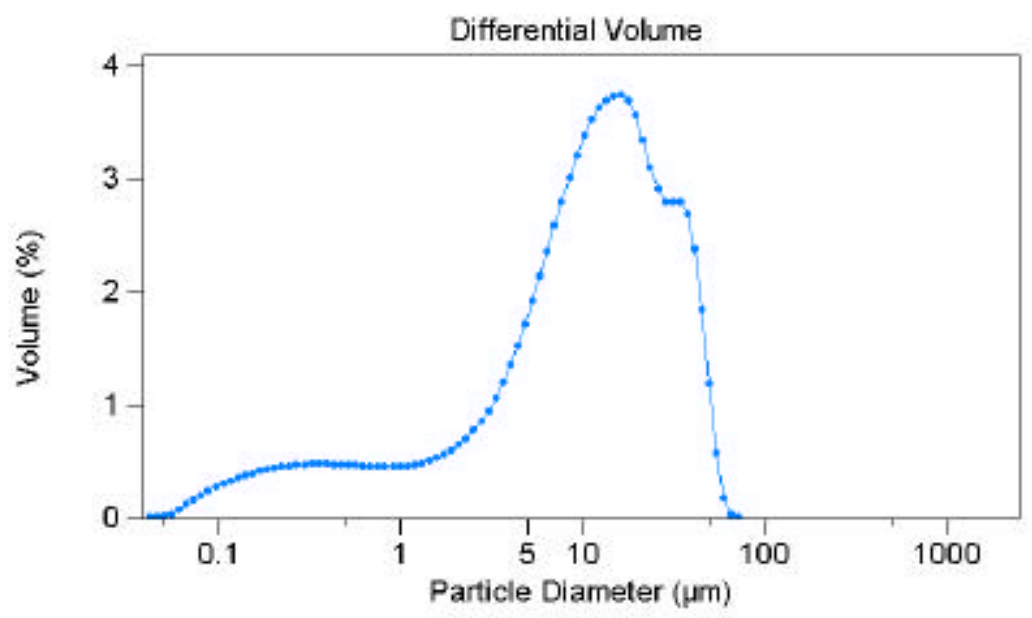

Figure 4.26. Particle Size Distribution for the Site Below the Sedimentation Pond (Site 3b), January 3, 2001.

\subsubsection{Upper Laurel Run, January 3, 2001}

Through evaluation of the results of water quality analyses performed on the sample collected at Upper Laurel Run it was determined that all the parameters were within the limits previously identified in Table 4.1, with the exception of $\mathrm{pH}$ and aluminum concentration. Turbidity was 2.85 NTU and total suspended solids concentration was $1.50 \mathrm{mg} / \mathrm{L}$. $\mathrm{pH}$ was 6.34 . Alkalinity was $10.1 \mathrm{mg} / \mathrm{L}$ as $\mathrm{CaCO}_{3}$ and acidity was $0.00 \mathrm{mg} / \mathrm{L}$ as $\mathrm{CaCO}_{3}$. Conductivity was $153 \mu \mathrm{S} / \mathrm{cm}$, sulfate concentration was $26.4 \mathrm{mg} / \mathrm{L}$, iron concentration was $1.42 \mathrm{mg} / \mathrm{L}$, and chloride concentration was $20.2 \mathrm{mg} / \mathrm{L}$. Manganese concentration was $0.42 \mathrm{mg} / \mathrm{L}$. Aluminum concentration was $0.15 \mathrm{mg} / \mathrm{L}$. Calcium, total hardness, and magnesium were $14.0 \mathrm{mg} / \mathrm{L}, 53.4 \mathrm{mg} / \mathrm{L}$ as $\mathrm{CaCO}_{3}$, and 4.43 
$\mathrm{mg} / \mathrm{L}$, respectively. Nitrate concentration was $0.31 \mathrm{mg} / \mathrm{L}$ and ammonia concentration was $0.02 \mathrm{mg} / \mathrm{L}$. Nitrite and phosphate concentrations were below detection limits.

Flow was not measured, as insufficient water was present to fill the flow meter conduit. Particle size analysis was performed on the sample collected at this site; however the particle concentration was not large enough to detect.

\subsubsection{The Bench Drainage, January 3, 2001}

With the exception of five parameters $(\mathrm{pH}$, conductivity, iron concentration, manganese concentration, and aluminum concentration) the water quality data were within the limits specified previously in Table 4.1. Turbidity was 6.33 NTU and total suspended solids concentration was $34.4 \mathrm{mg} / \mathrm{L}$. The $\mathrm{pH}$ was 3.18 . Alkalinity could not be determined because the sample $\mathrm{pH}$ was below the methyl orange indicator titrametric endpoint, 4.3. The acidity was $101 \mathrm{mg} / \mathrm{L}$ as $\mathrm{CaCO}_{3}$. Conductivity was $612 \mu \mathrm{S} / \mathrm{cm}$, sulfate concentration was $231 \mathrm{mg} / \mathrm{L}$, iron concentration was $18.2 \mathrm{mg} / \mathrm{L}$, manganese concentration was $2.25 \mathrm{mg} / \mathrm{L}$, and aluminum concentration was $2.6 \mathrm{mg} / \mathrm{L}$. Calcium was $45.0 \mathrm{mg} / \mathrm{L}$, total hardness was $184 \mathrm{mg} / \mathrm{L}$ as $\mathrm{CaCO}_{3}$, and magnesium was $17.1 \mathrm{mg} / \mathrm{L}$. The chloride concentration, the nitrite concentration, the ammonia concentration, nitrate concentration, and the phosphate concentration were below detection limits.

Flow was not measured, as insufficient water was present to fill the flow meter conduit. Particle size distribution for the site below the sedimentation pond is presented in Figure 4.27. The mean particle diameter at Site 5 was $37.4 \mu \mathrm{m}$. 


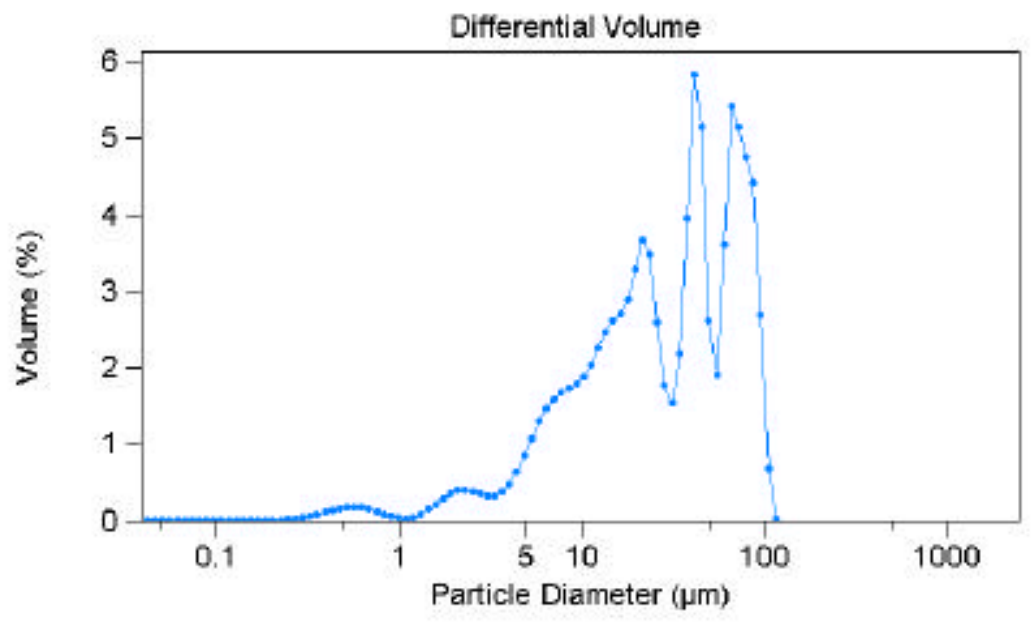

Figure 4.27. Particle Size Distribution for the Bench Drainage (Site 5), January 3, 2001.

\subsection{BENTHIC MACRO INVERTEBRATE AND FISH ASSESSMENT}

On November 12, 2000, a benthic macro invertebrate assessment of Laurel Run was conducted in an effort to develop a more complete understanding of the water quality and potential biological impacts in the drainage basin. An assessment of the fish population in the Laurel Run drainage basin was also conducted on the same day utilizing an electro shocking unit.

The benthic macro invertebrate metrics were classified as described previously in Table 3.3. Each site sampled was replicated at least once for each riffle habitat as a method of quality control and quality assurance. Four replicates were conducted on Sites 2, 2a, and $2 \mathrm{~b}$. Sites 1 and 3 had an insufficient riffle habitat, therefore, Site 1 was replicated three times, and Site 3 was sampled only once. The average WVSCI scores were calculated and are tabulated and rated according to the criteria presented previously 
in Table 3.4. The benthic macro invertebrate metrics for Laurel Run are presented in

Table 4.10.

Table 4.10. Benthic Macro Invertebrate Metrics for Laurel Run.

\begin{tabular}{|c|c|c|c|c|c|c|c|c|}
\hline $\begin{array}{c}\text { Site/ } \\
\text { Replicate }\end{array}$ & $\begin{array}{c}\text { Total } \\
\text { Individual }\end{array}$ & $\begin{array}{l}\text { Total } \\
\text { EPT }\end{array}$ & $\%$ EPT & $\begin{array}{c}\% \\
\text { CHIRO }\end{array}$ & $\begin{array}{r}\% 2 \\
\text { DOM }\end{array}$ & HBI & WVSCI & \begin{tabular}{|l} 
Average \\
WVSCI
\end{tabular} \\
\hline $1 / 1$ & 88 & 79 & 89.8 & 4.55 & 62.5 & 2.36 & 67.2 & \multirow{3}{*}{$\begin{array}{l}68.7 \\
\text { Fair }\end{array}$} \\
\hline $1 / 2$ & 78 & 52 & 66.7 & 10.3 & 48.7 & 3.83 & 66.6 & \\
\hline $1 / 3$ & 77 & 65 & 84.4 & 6.49 & 61.0 & 2.45 & 70.3 & \\
\hline $2 / 1$ & 6 & 5 & 83.3 & 0.00 & 83.3 & 4.67 & 62.3 & \multirow{4}{*}{$\begin{array}{l}62.6 \\
\text { Fair }\end{array}$} \\
\hline $2 / 2$ & 19 & 13 & 68.4 & 26.3 & 63.2 & 3.37 & 57.3 & \\
\hline $2 / 3$ & 45 & 32 & 71.1 & 20.0 & 51.1 & 3.76 & 61.0 & \\
\hline $2 / 4$ & 67 & 56 & 83.6 & 11.9 & 61.2 & 4.18 & 70.0 & \\
\hline $2 a / 1$ & 96 & 86 & 89.6 & 6.25 & 65.6 & 2.14 & 73.5 & \multirow{4}{*}{$\begin{array}{c}74.9 \\
\text { Good }\end{array}$} \\
\hline $2 a / 2$ & 113 & 90 & 79.7 & 13.3 & 55.8 & 2.50 & 75.5 & \\
\hline $2 a / 3$ & 108 & 95 & 88.0 & 6.48 & 60.2 & 2.08 & 78.3 & \\
\hline $2 a / 4$ & 101 & 83 & 82.2 & 10.9 & 34.7 & 3.17 & 72.4 & \\
\hline $2 b / 1$ & 29 & 26 & 89.7 & 0.00 & 48.3 & 2.69 & 65.1 & \multirow{4}{*}{$\begin{array}{l}59.2 \\
\text { Fair }\end{array}$} \\
\hline $2 \mathrm{~b} / 2$ & 12 & 4 & 33.3 & 33.3 & 41.7 & 5.08 & 52.3 & \\
\hline $2 \mathrm{~b} / 3$ & 12 & 9 & 75.0 & 16.7 & 75.0 & 1.75 & 54.1 & \\
\hline $2 \mathrm{~b} / 4$ & 39 & 34 & 87.2 & 7.69 & 46.2 & 3.05 & 65.4 & \\
\hline $3 / 1$ & 10 & 3 & 30.0 & 50.0 & 70.0 & 4.20 & 46.9 & Fair* \\
\hline
\end{tabular}

*No average WVSCI score calculated for Site 3 as only 1 sample was collected.

The total percent filterer to shredder, as described previously in Table 3.3 , is a measure of the number of tolerant feeding groups to intolerant feeding groups. Filterers are macro invertebrates that feed on dissolved pollutants (e.g., nitrogen, phosphorus, etc.) in the water and generally increase in population as the water degradation increases. Shredders are macro invertebrates that feed from leaves and debris in the water and decrease in population as the water degradation increases. The filterer to shredder percentage for each site and replicate is presented in Table 4.11. 
Table 4.11. The Filterer to Shredder (F:S) Percentage.

\begin{tabular}{|c|c|c|c|c|}
\hline Site/Replicate & Total Filterer & Total Shredder & F:S, \% & Average F:S, \% \\
\hline $1 / 1$ & 19 & 57 & 33.3 & \multirow{3}{*}{35.9} \\
\hline $1 / 2$ & 12 & 39 & 30.8 & \\
\hline $1 / 3$ & 17 & 39 & 43.6 & \\
\hline $2 / 1$ & 5 & 1 & 500 & \multirow{4}{*}{232} \\
\hline $2 / 2$ & 5 & 8 & 62.5 & \\
\hline $2 / 3$ & 16 & 16 & 100 & \\
\hline $2 / 4$ & 40 & 15 & 267 & \\
\hline $2 a / 1$ & 3 & 63 & 4.76 & \multirow{3}{*}{23.5} \\
\hline $2 \mathrm{a} / 2$ & 8 & 51 & 15.7 & \\
\hline $2 a / 3$ & 20 & 40 & 50.0 & \\
\hline $2 b / 1$ & 8 & 17 & 47.1 & \multirow{3}{*}{111} \\
\hline $2 b / 2$ & 2 & 1 & 200 & \\
\hline $2 \mathrm{~b} / 3$ & 12 & 14 & 85.7 & \\
\hline
\end{tabular}

The mean wet weight a measure of the amount of biomass present was determined for each site surveyed. The mean wet weight for Laurel Run as collected at each sampling station is presented in Table 4.12.

Table 4.12. The Mean Wet Weight for Laurel Run as Collected at Each Site.

\begin{tabular}{|c|c|c|}
\hline Site & Mean Wet Weight (g) & Number of Replicates (N) \\
\hline 1 & 0.5 & 3 \\
\hline 2 & 0.2 & 4 \\
\hline $2 \mathrm{a}$ & 1.6 & 4 \\
\hline $2 \mathrm{~b}$ & 0.2 & 4 \\
\hline 3 & 0.2 & 1 \\
\hline
\end{tabular}

Lower Laurel Run, Site 1, had an average of 81 total individuals, an average EPT of 65, an average percent EPT of $80 \%$, an average percent Chironomidae of $7.1 \%$, and an average percent of the two dominating species of $57 \%$. The average WVSCI score for Lower Laurel Run was 68.7, which was fair. The average percentage of filterer to shredder was $36 \%$. Mean wet weight at Lower Laurel Run was $0.5 \mathrm{~g}$. Three green sunfish, Lepomis cyanellus, were collected. 
The box culvert, Site 2, had an average total number of individuals of 34 and a total EPT of 26. The average percent EPT was $78 \%$ and the average percent chironomidae was $15 \%$. The average filterer to shredder percentage was $232 \%$. Mean wet weight was $0.2 \mathrm{~g}$ at the box culvert. No fish were collected at the box culvert. The average WVSCI score was 62.6, which was classified as "fair".

Site $2 \mathrm{a}$, above the spoils pile, where the impact of the highway construction was thought to be the least, exhibited the greatest taxa richness and a high number of intolerant genera, on each of the four replicate samples, with an average total individuals of 104. Intolerant taxa, genera with less tolerance to water quality perturbation, were found at site 2a. The maximum number of Ephemeroptera (mayfly nymphs), Plecoptera (stonefly naiads), and Trichoptera (caddisfly larvae) were found at Site 2a, with an average total number of 88 EPT species, as well as the largest average percent EPT and the lowest average percent Chironomidae, $85 \%$ and $9.2 \%$, respectively. The samples were comprised of an average $54 \%$ of the two dominating species. The average filterer to shredder percentage was $24 \%$. Mean wet weight was $1.6 \mathrm{~g}$ at the site above the spoils pile. The average WVSCI score was 74.9 , which was good (close to 78 for classification as "very good"). No fish were found above the spoils pile, which could be due to the small size of the stream.

The site below the spoils pile, Site $2 b$, had results indicative of impaired waters. The total number of individuals averaged 23 and the average total EPT was 20. The percent average EPT was $71 \%$ and the percent chironomidae was $14 \%$. The percent belonging to the two dominating species was 53\%. The average filterer to shredder 
percentage was $111 \%$. Mean wet weight was $0.2 \mathrm{~g}$ at the site below the spoils pile. No fish were observed at the site below the spoils pile.

Middle Laurel Run, Site 3, at the outlet of the sedimentation pond, yielded the least number of taxa and total individuals. A total of ten individuals were found, only $30 \%$ of these were EPT, $50 \%$ belonged to the chironomidae species, and $70 \%$ were of the two dominating species. An insufficient amount of biomass was collected to determine the percentage of filterer to shredders. Mean wet weight was $0.2 \mathrm{~g}$, at Middle Laurel Run. Twenty-two young green sunfish, or Lepomis cyanellus, were electro shocked between Middle Laurel Run and the site below the sedimentation pond.

Benthic macro invertebrates could not be collected at Upper Laurel Run due to a lack of riffles at the site. However, three Lepomis cyanellus, two black nose dace or Rhinichthys atratulus, and a stoneroller, Campostoma anomalum were observed at Upper Laurel Run. At the site located along the bench drainage, neither fish nor benthic macro invertebrates were collected. 


\subsection{DISCUSSION}

Due to the acidic geochemistry of the soils and rock found in West Virginia and the Mid Appalachian region, highway construction can no longer be approached in the traditional manner, where a proposed route is excavated, graded, and poured. Rather, roadway construction through West Virginia, especially in areas of historical mining, should be handled in a similar manner to mining operations, with the development and employment of analogous preventive techniques to maintain environmental integrity. To effect this paradigm shift, roadway engineers and designers must begin to think as miners by first identifying potential acidity and metal loading sources, and second by implementing the appropriate precautionary methods. Equally, remediation techniques employed in post-mining operations can be utilized to rectify unintentional impacts, which may have occurred as a result of prior roadway construction.

Sedimentation basins or ponds were employed in two different locations along Laurel Run (Sites 3a and 4 on Figure 3.1) to mitigate solids loading during construction; however, no formal plan was made to address the acid mine and rock drainage in the area impacted by highway construction. Excess cut, termed "unsuitable material" for fill by the WVDOH, was stock piled and an attempt to revegetate the piles was made after construction was complete. Aside from the common highway runoff and erosion mitigation practices applied during construction of Corridor $H$, no attempt was made to mitigate low $\mathrm{pH}$ conditions and high metal loads produced as a result of acid mine and rock drainage.

Through evaluation and examination of the water quality data, benthic macro 
invertebrates and fish populations, and construction plans of Corridor $H$ for a two mile section of highway between Buckhannon and Elkins, West Virginia, west of the Tygart Valley River and a one-half mile section east of the river, an understanding of the impact of the highway construction on water quality and environmental health was obtained. Water, benthic macro invertebrate, and fish samples were collected at sites detailed in Section 3.1. These samples were analyzed and interpreted in order to understand existing conditions and as a means to develop recommendations for changes in construction practices, which may be implemented to minimize water quality impacts in future construction, as well as remediation techniques for existing impacted areas.

\subsection{SPOILS PILE}

Through an evaluation of the construction plans, it was determined that the main prevention/remediation techniques employed by the WVDOH during the construction of this segment of Corridor $H$ were the attempted revegetation of what was believed to be an excess fill pile and the implementation of two sedimentation ponds. These methods were standard practices according to WVDOH contractor's proposal protocols (WVDOH 1993), however, in retrospect, the construction specifications were not designed to specifically account for the disturbance and handling of acidic material to minimize environmental impacts. For example, revegetation of the fill piles, which were in fact spoils piles, with a seed mix of wheat, rye, and fescue grasses (WVDOH 1993) failed as the acidic conditions were unsuitable to sustain the vegetation.

Due to the geotechnical nature of the rock through which the highway was cut, excess fill and "unsuitable material" became a disposal issue for the WVDOH. As with 
typical construction practices, the excess fill was piled within a quarter of mile of the alignment and an attempt was made to revegetate the mound. Unfortunately, the fill from Corridor $H$ contained acidic shale, pyretic rock, and coal seams, as presented in Table 8.1, Appendix, which contributed to the low $\mathrm{pH}$ and high dissolved metal concentrations observed in the ditch lines which drain into Laurel Run.

\subsubsection{Impact of Spoils Pile on Water Quality}

In order to better understand the water quality characteristics from waste piles created by the WVDOH through the disturbance of acidic shale and coal seams, as well as refuse from historic mining activity, samples were taken from sites located above and below the spoils pile which drains into Laurel Run, via a box culvert (Site 2, as presented previously in Figure 3.1.) An evaluation of data collected from Sites $2 a$ and $2 b$ was made to determine the impact on receiving water quality from such a spoils pile. Analytic data from above and below the spoils pile for each sampling date are presented graphically in Figures 5.1 through 5.14. Nutrient concentrations (i.e., nitrate, nitrite, phosphate, and ammonia), were generally near or below method detection limits, and are thus not discussed in subsequent sections. 


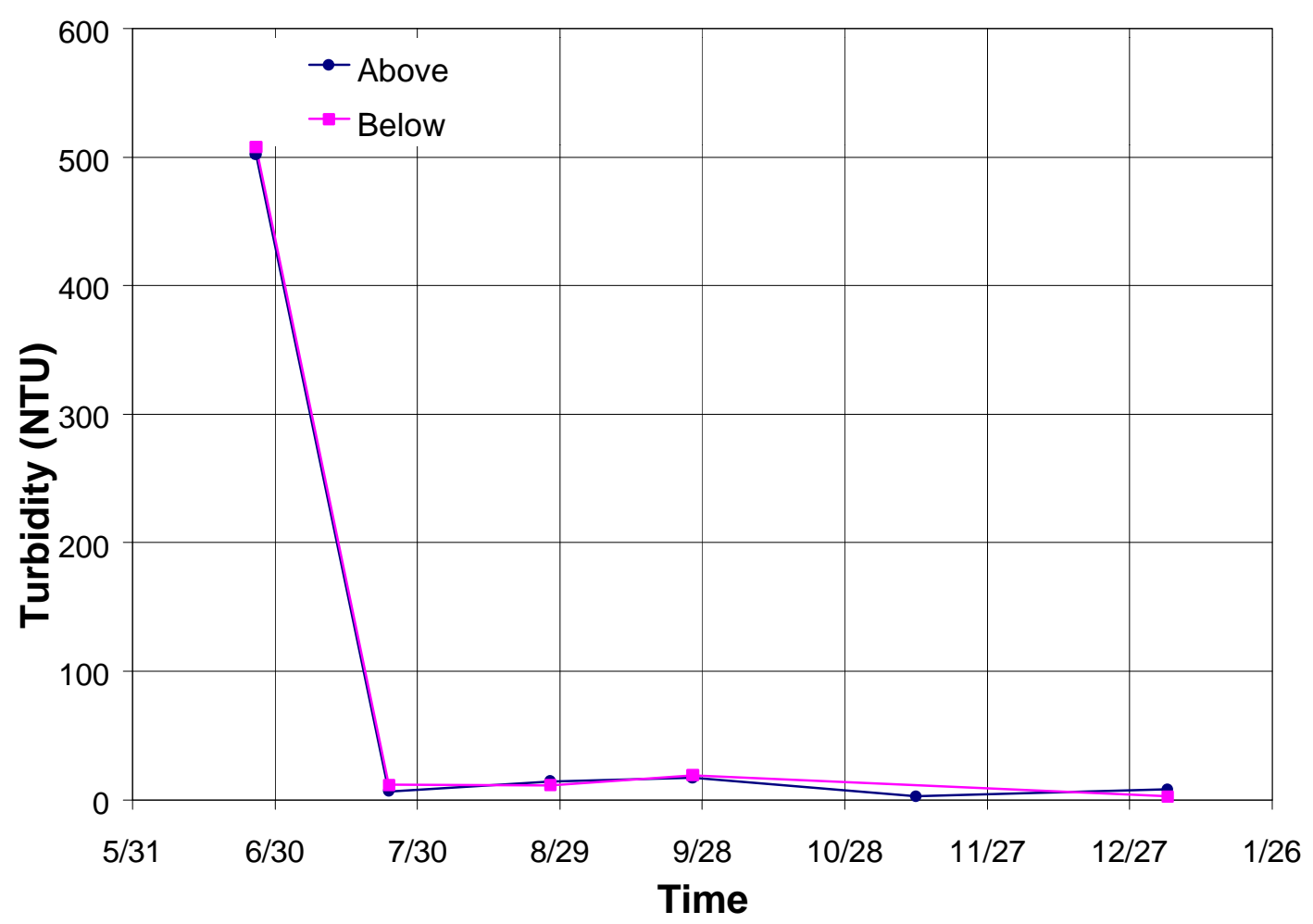

Figure 5.1. Turbidity Above and Below the Spoils Pile.

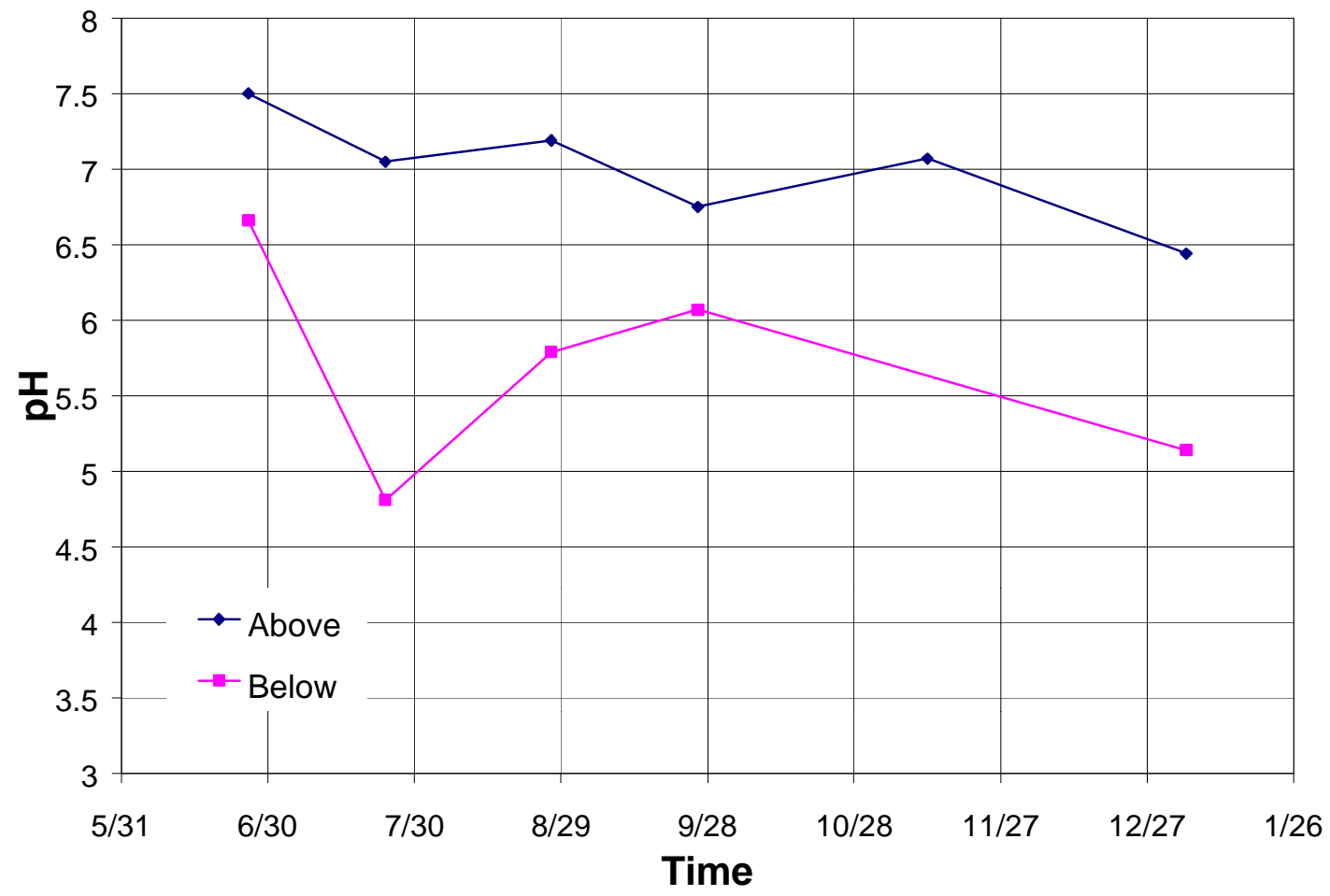

Figure 5.2. pH Above and Below the Spoils Pile. 


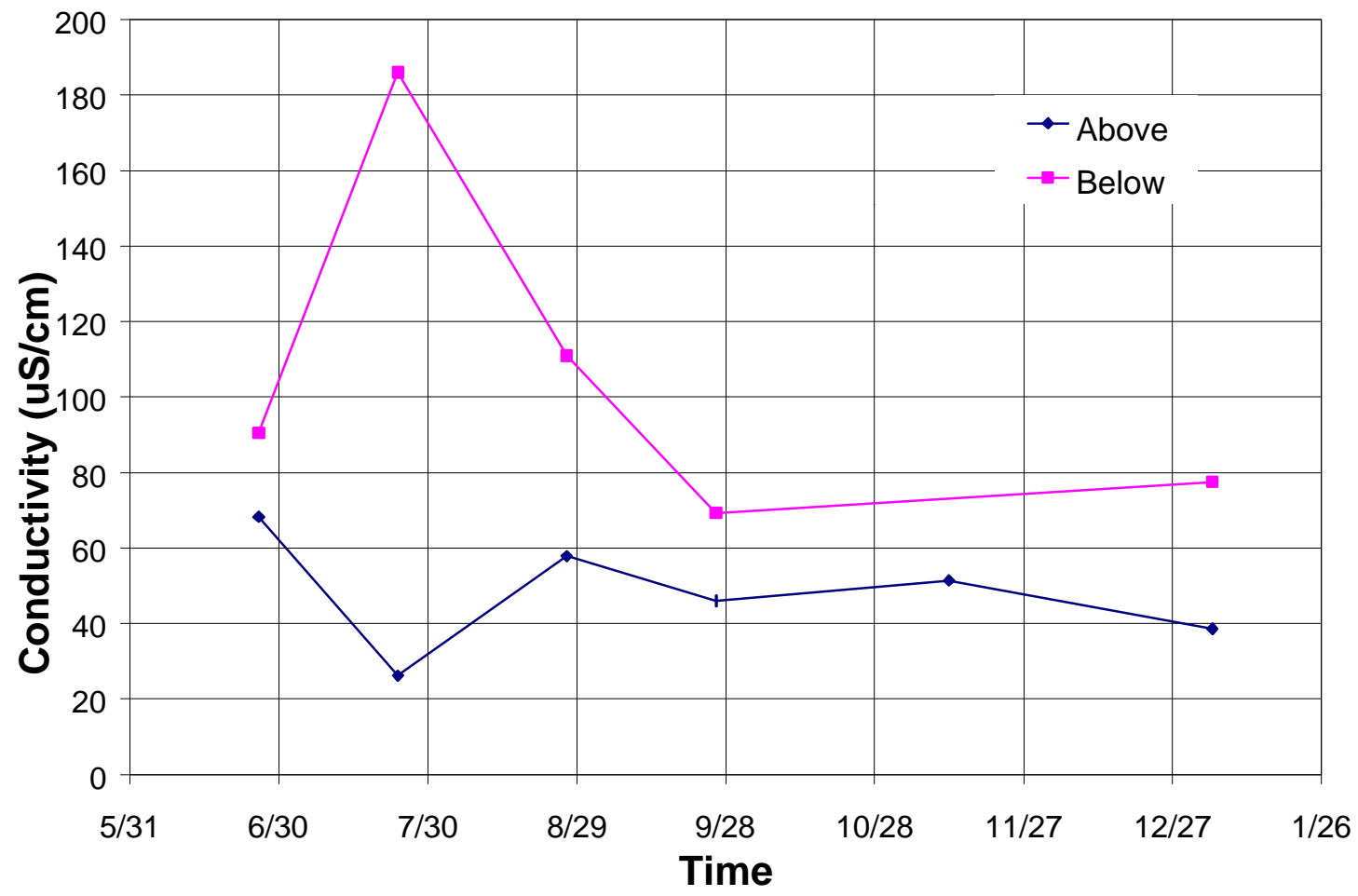

Figure 5.3. Conductivity Above and Below the Spoils Pile.

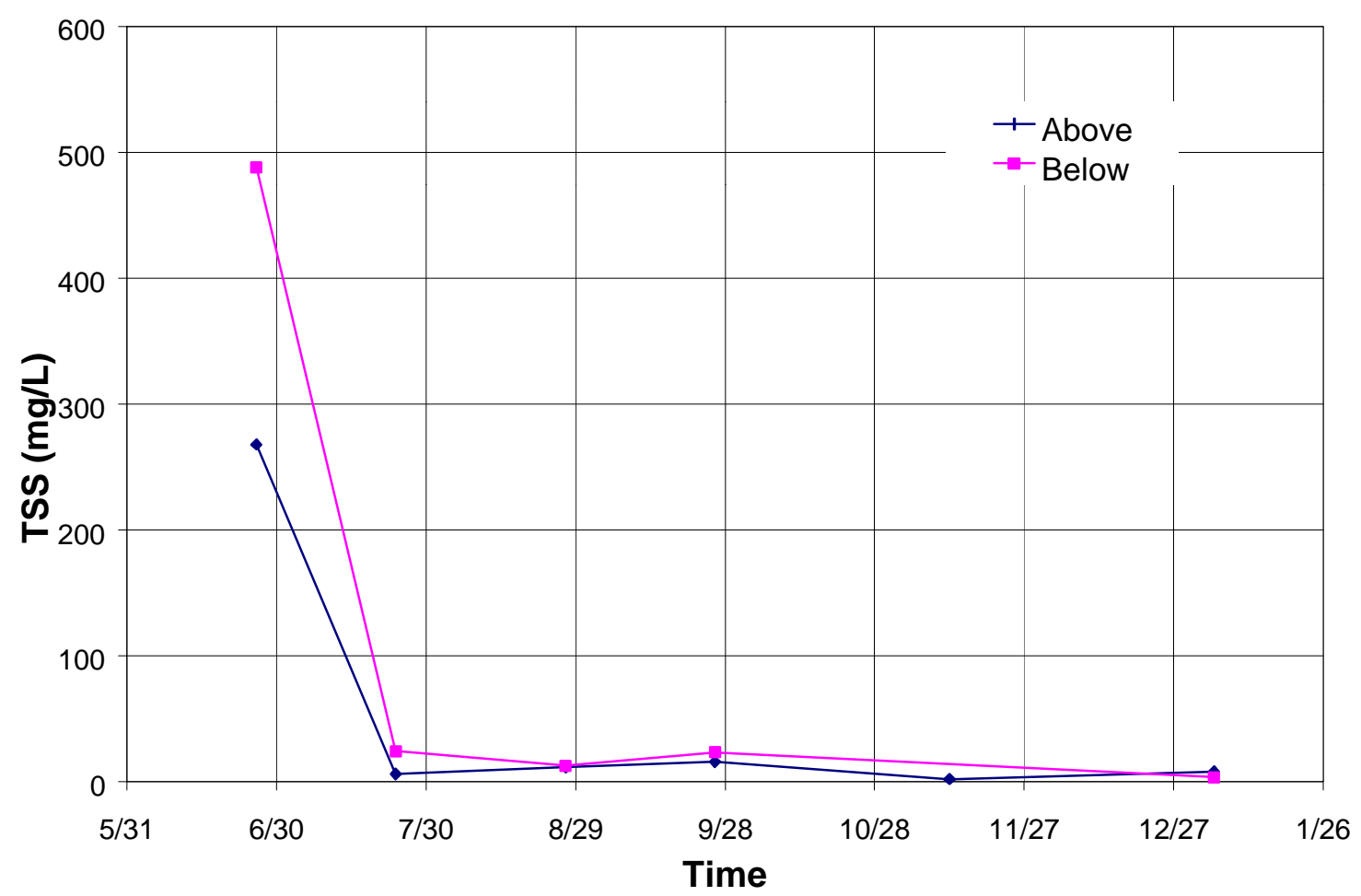

Figure 5.4. Total Suspended Solids Above and Below the Spoils Pile. 


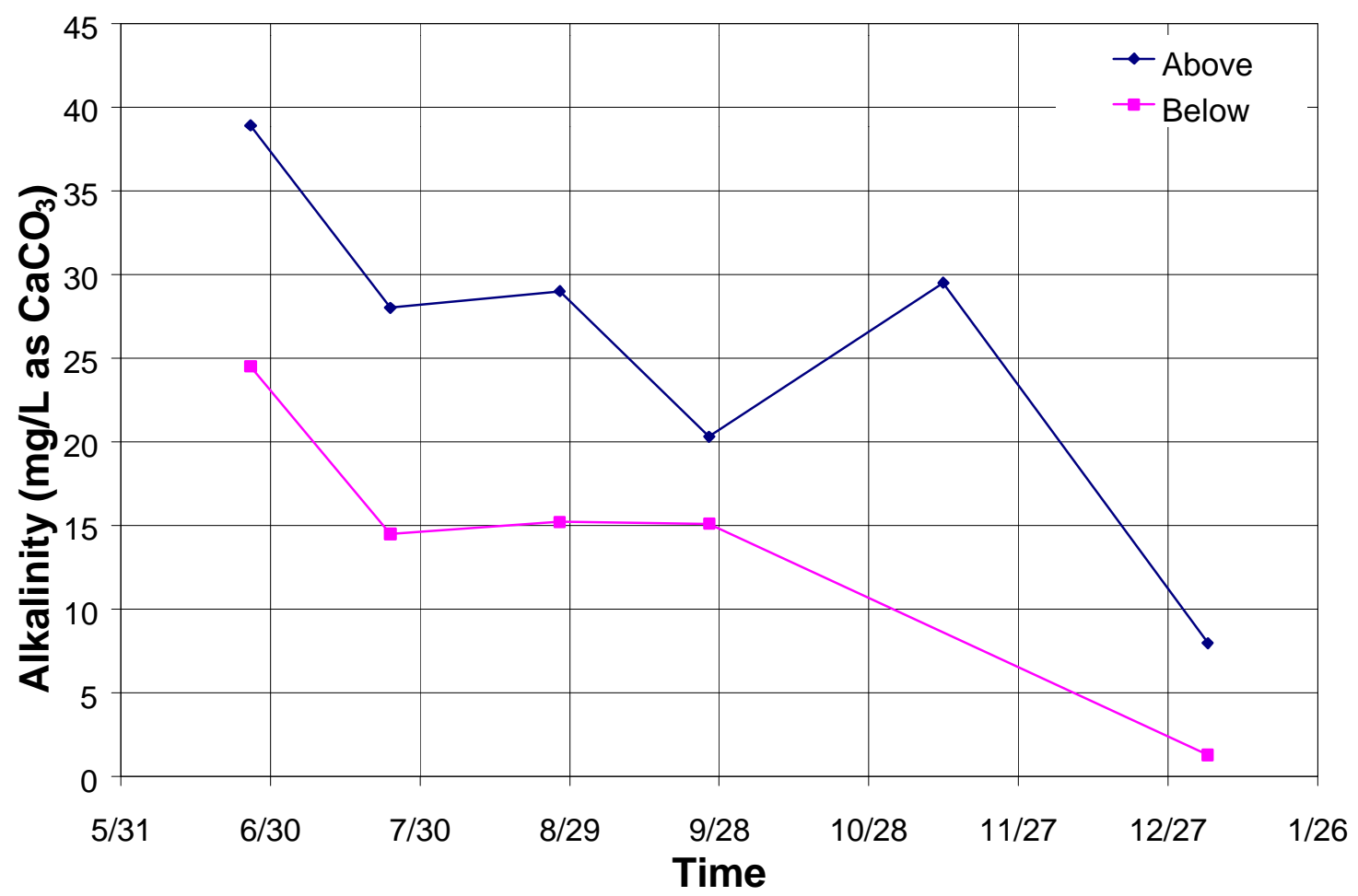

Figure 5.5. Alkalinity Above and Below the Spoils Pile.

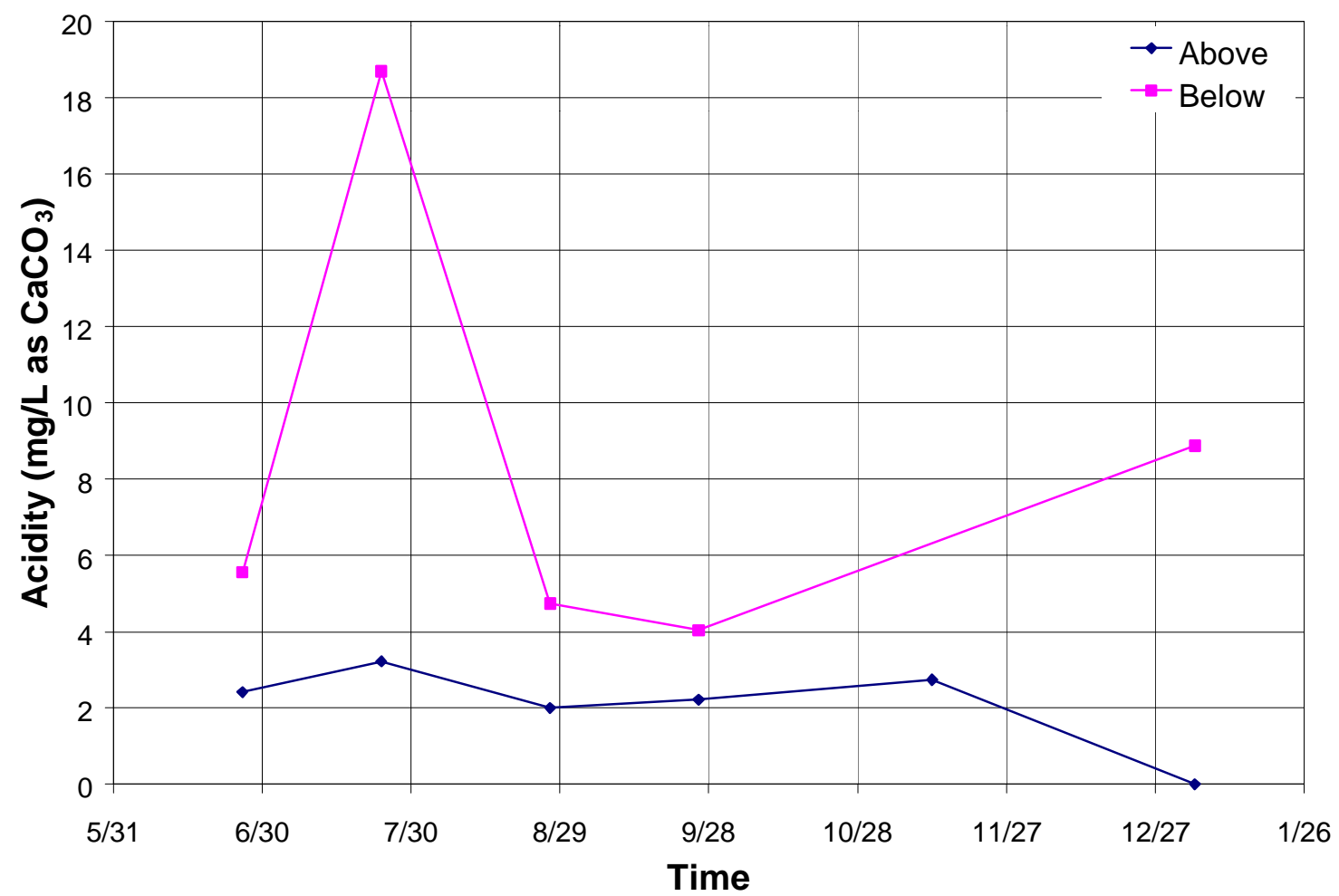

Figure 5.6. Acidity Above and Below the Spoils Pile. 


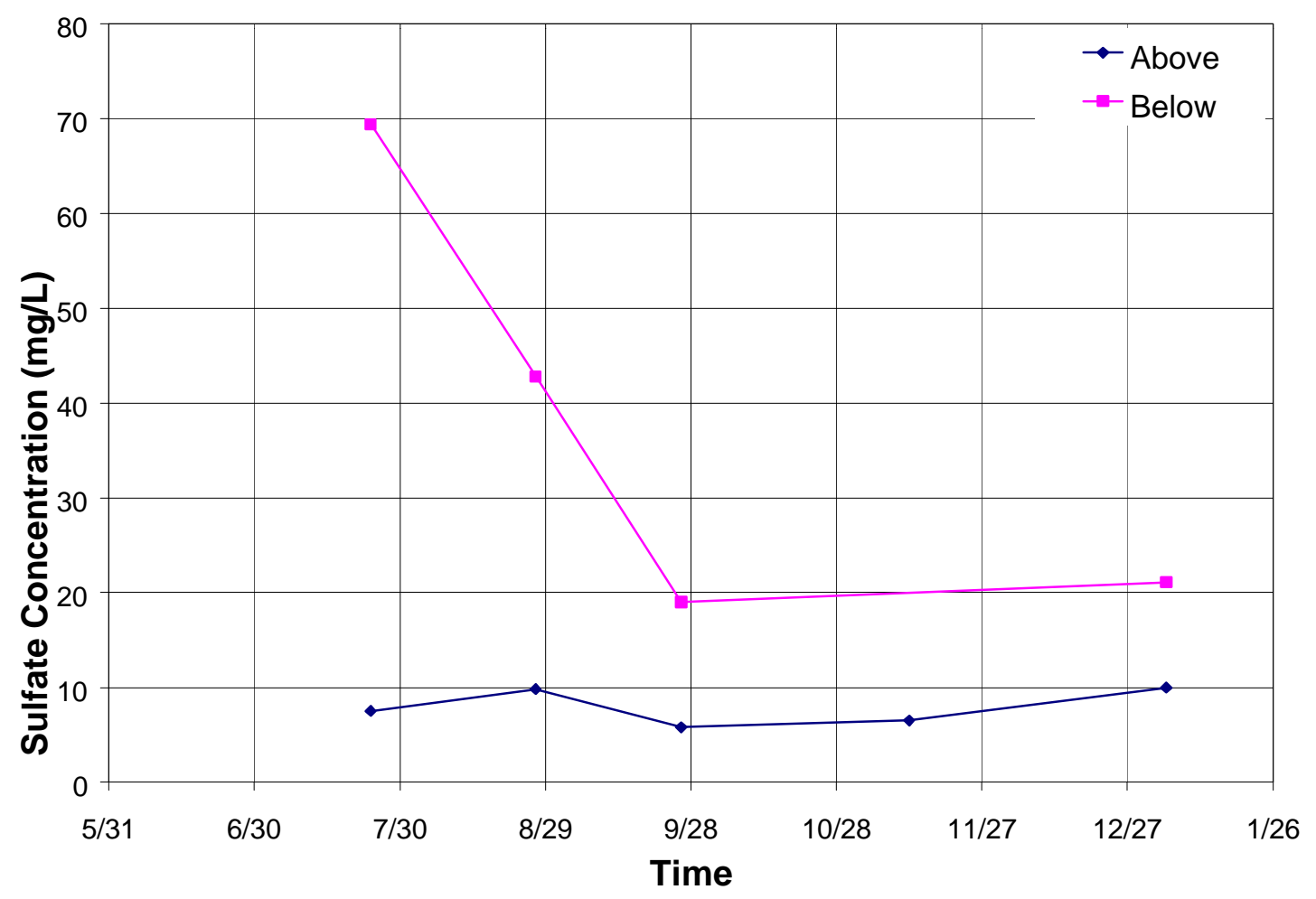

Figure 5.7. Sulfate Concentration Above and Below the Spoils Pile.

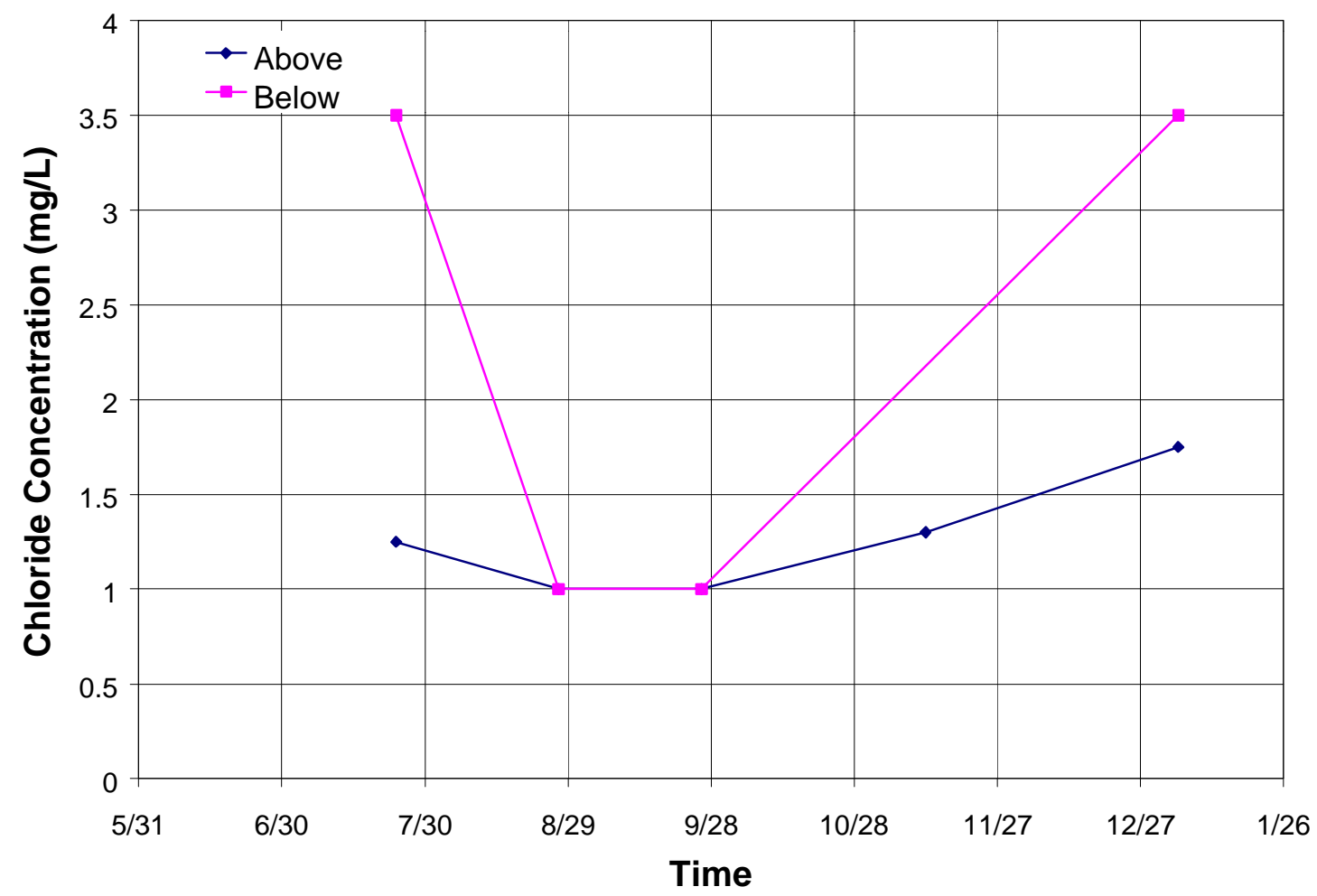

Figure 5.8. Chloride Concentration Above and Below the Spoils Pile. 


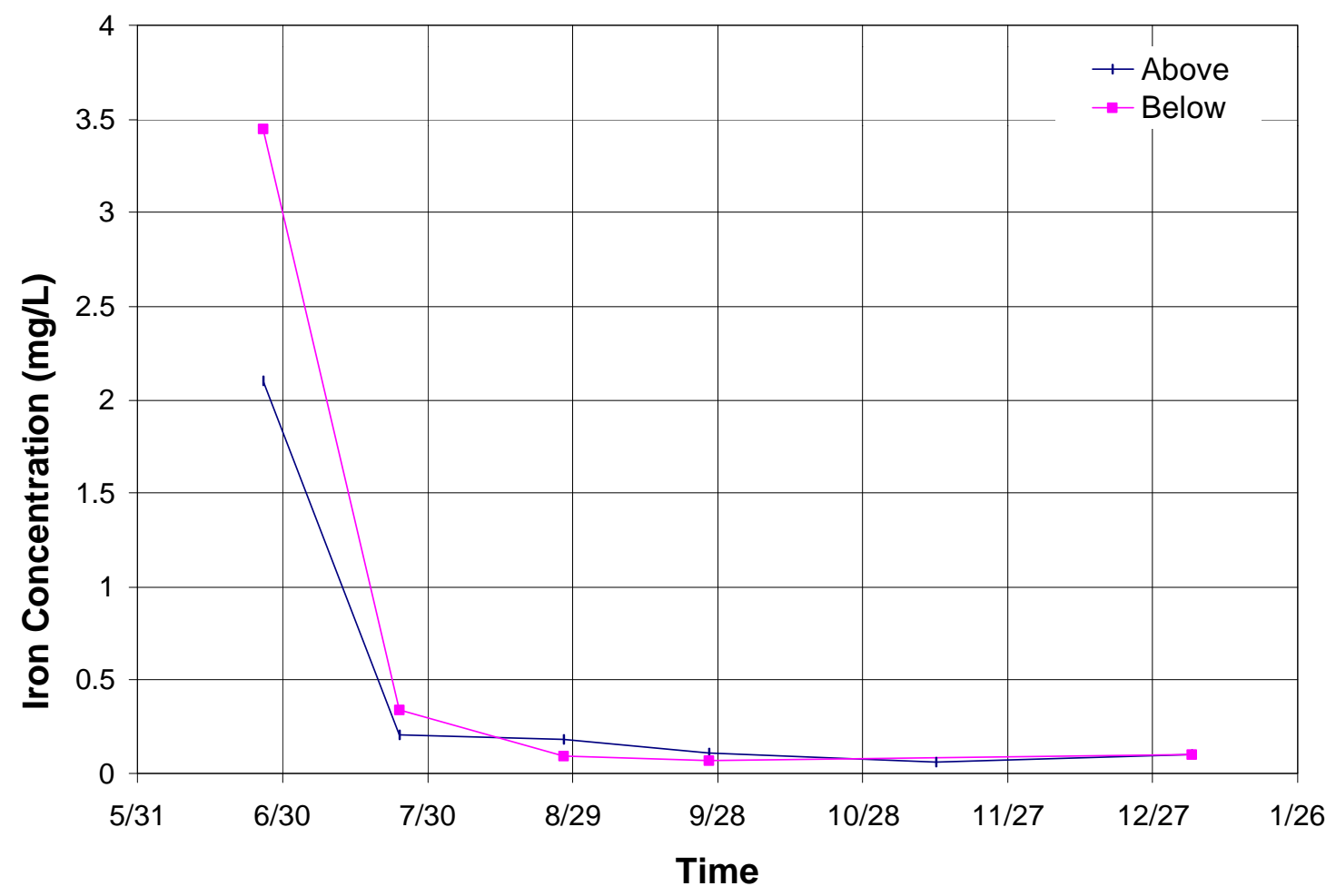

Figure 5.9. Iron Concentration Above and Below the Spoils Pile.

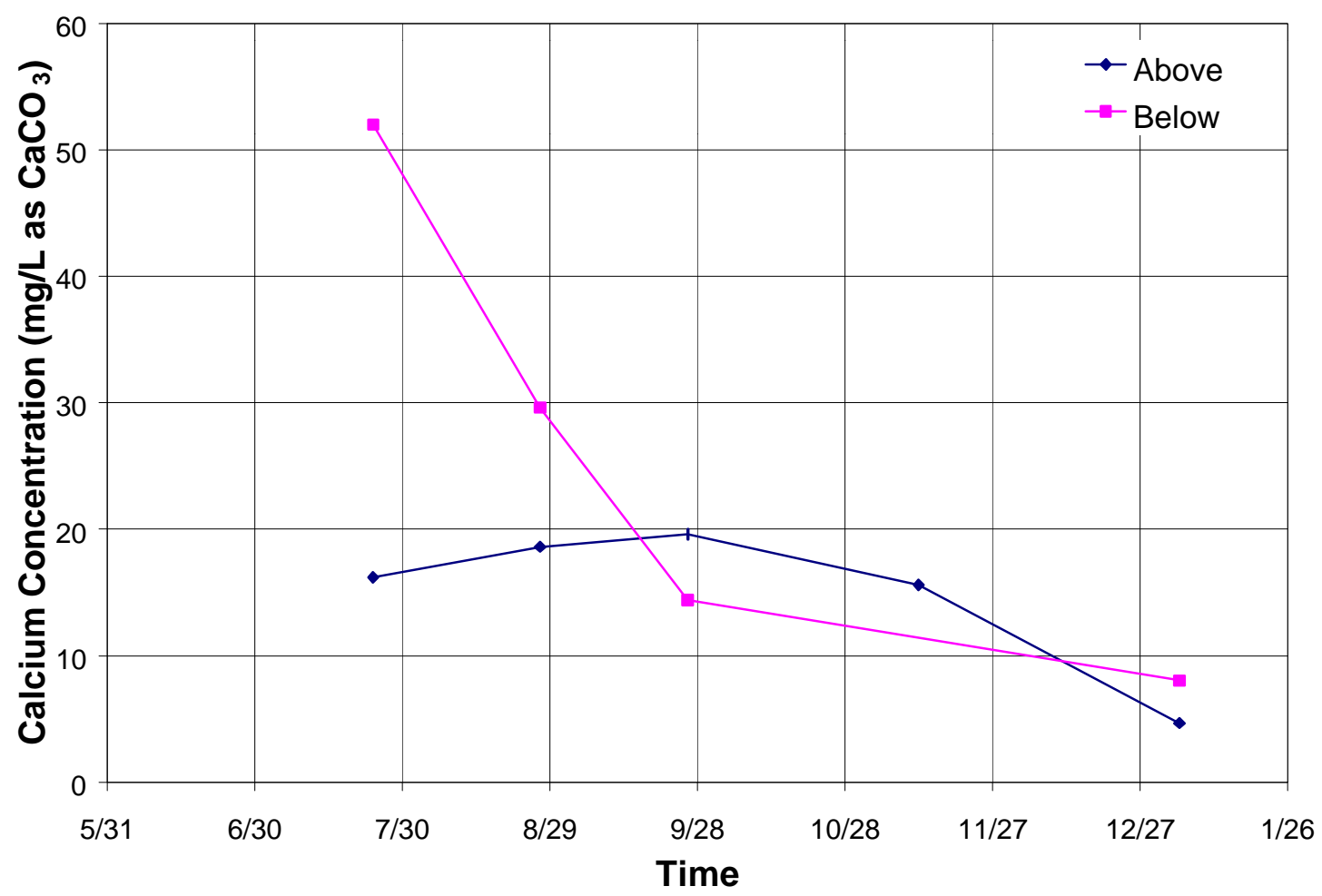

Figure 5.10. Calcium Concentration Above and Below the Spoils Pile. 


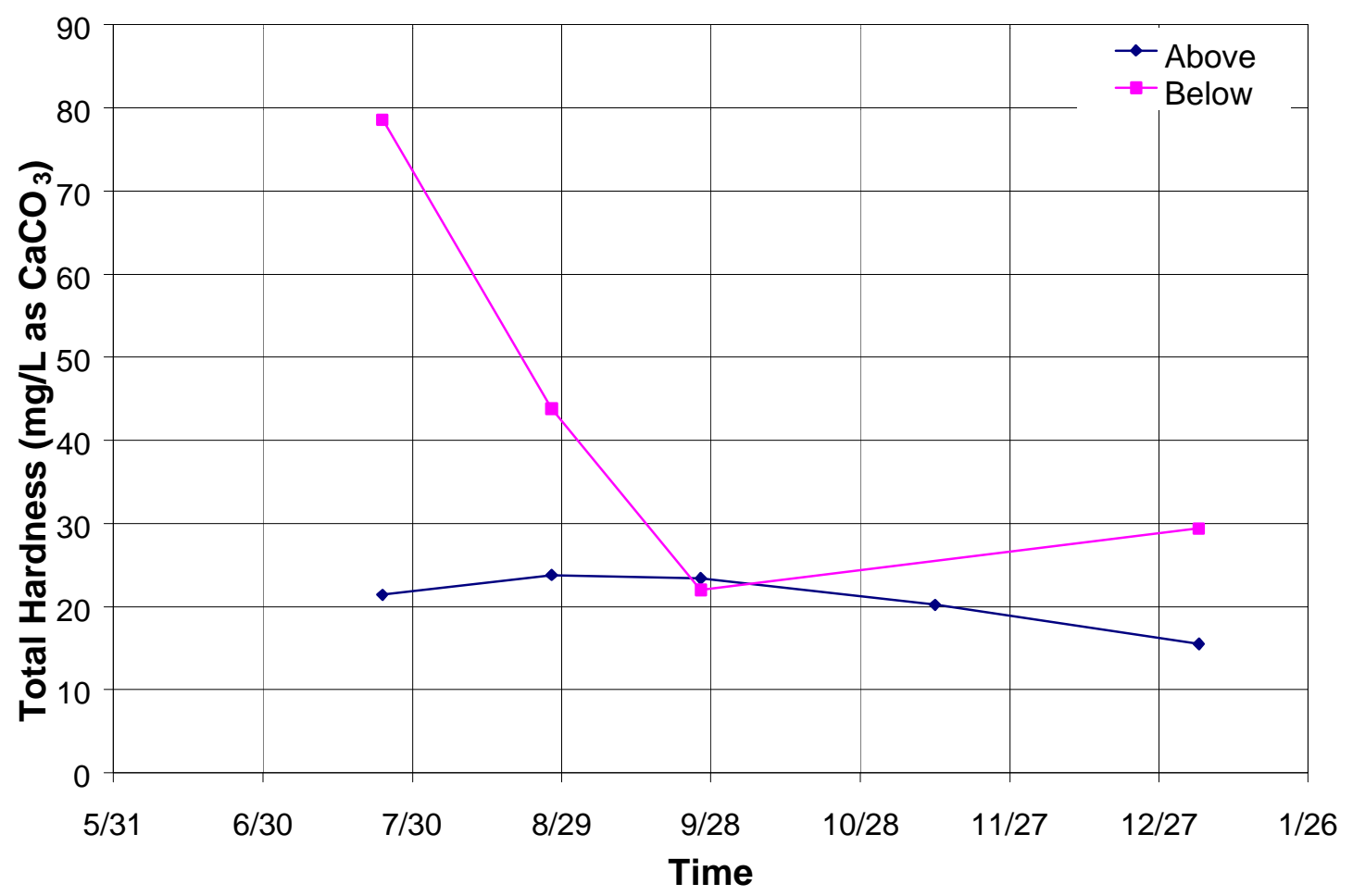

Figure 5.11. Total Hardness Concentration Above and Below the Spoils Pile.

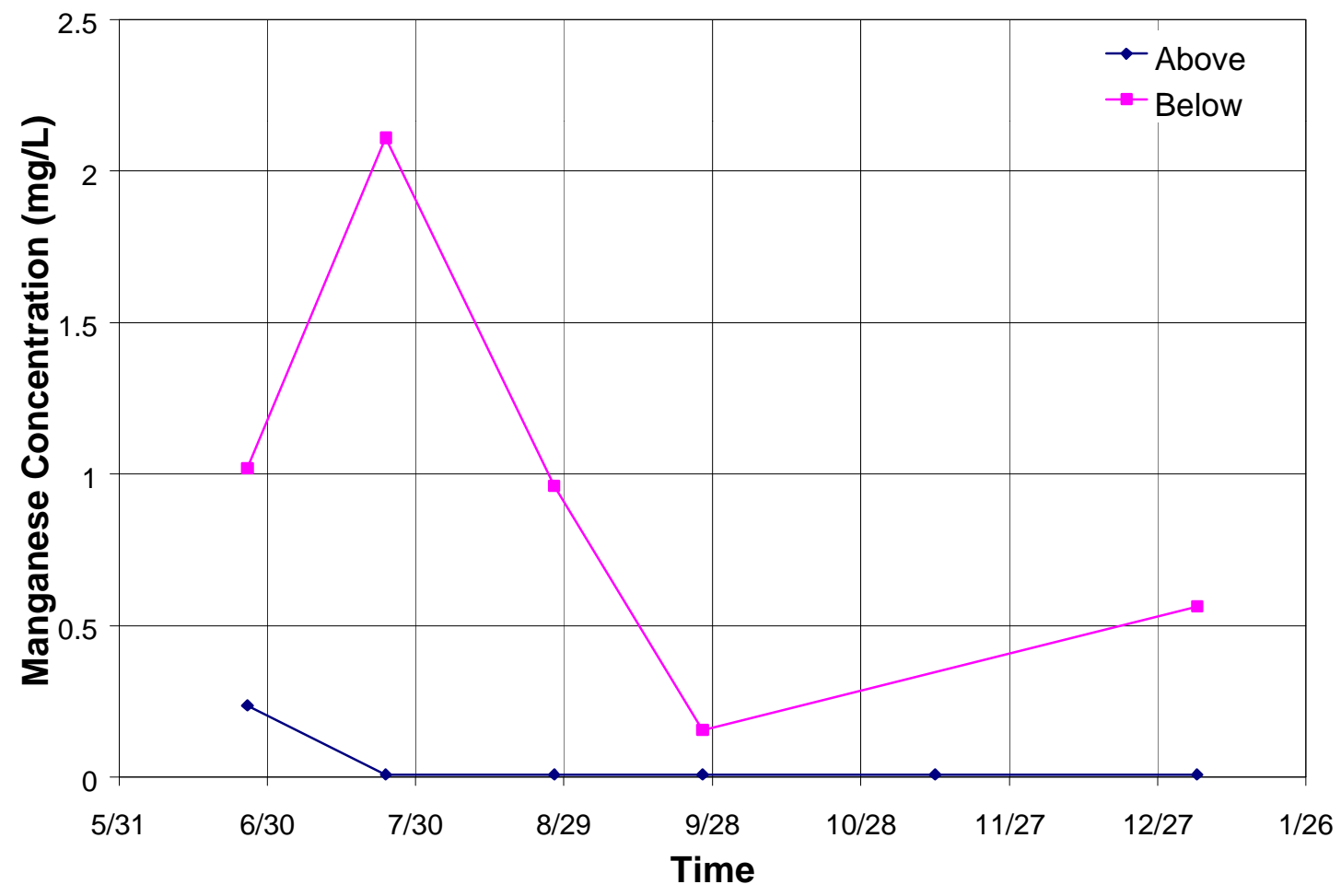

Figure 5.12. Manganese Concentration Above and Below the Spoils Pile. 


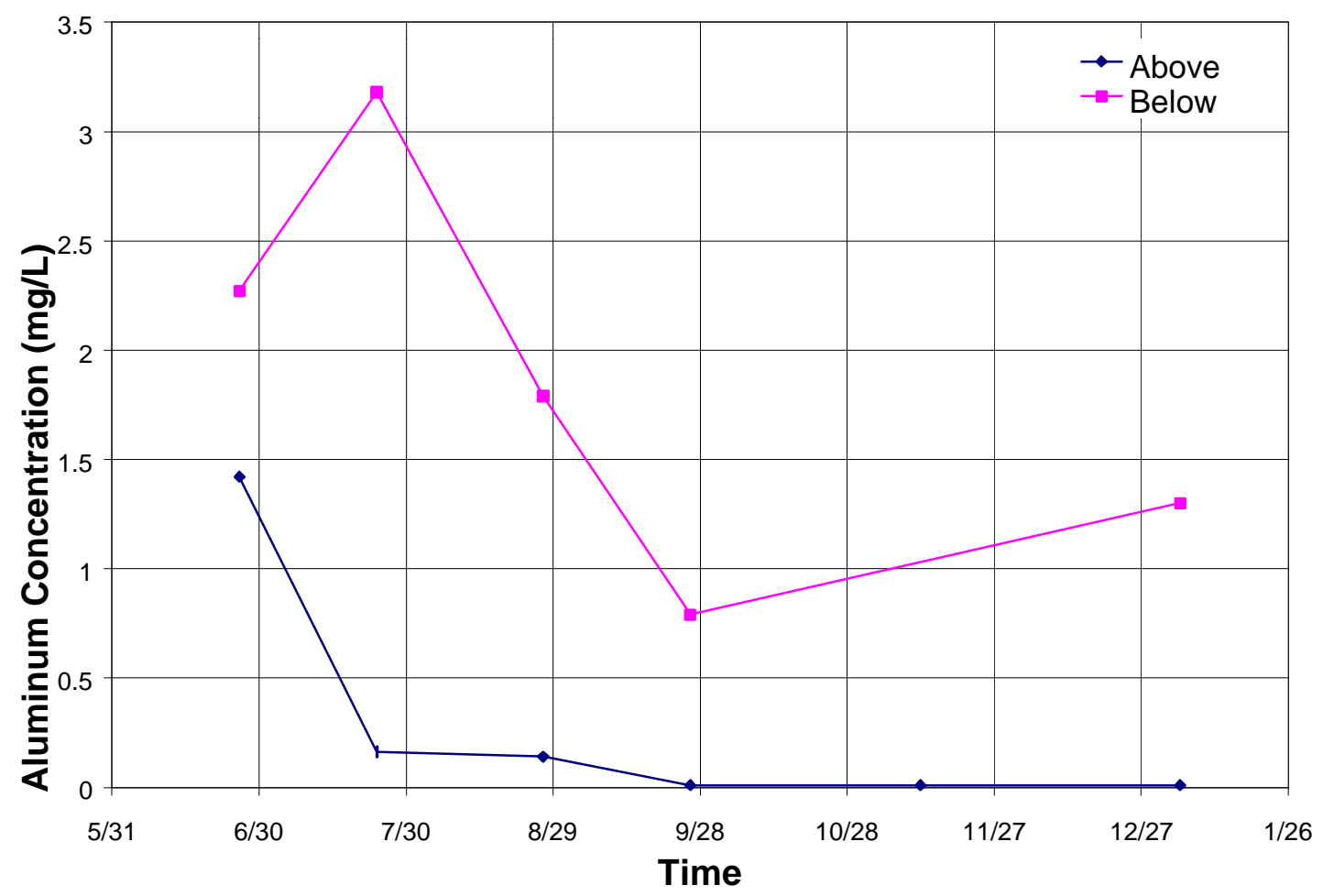

Figure 5.13. Aluminum Concentration Above and Below the Spoils Pile.

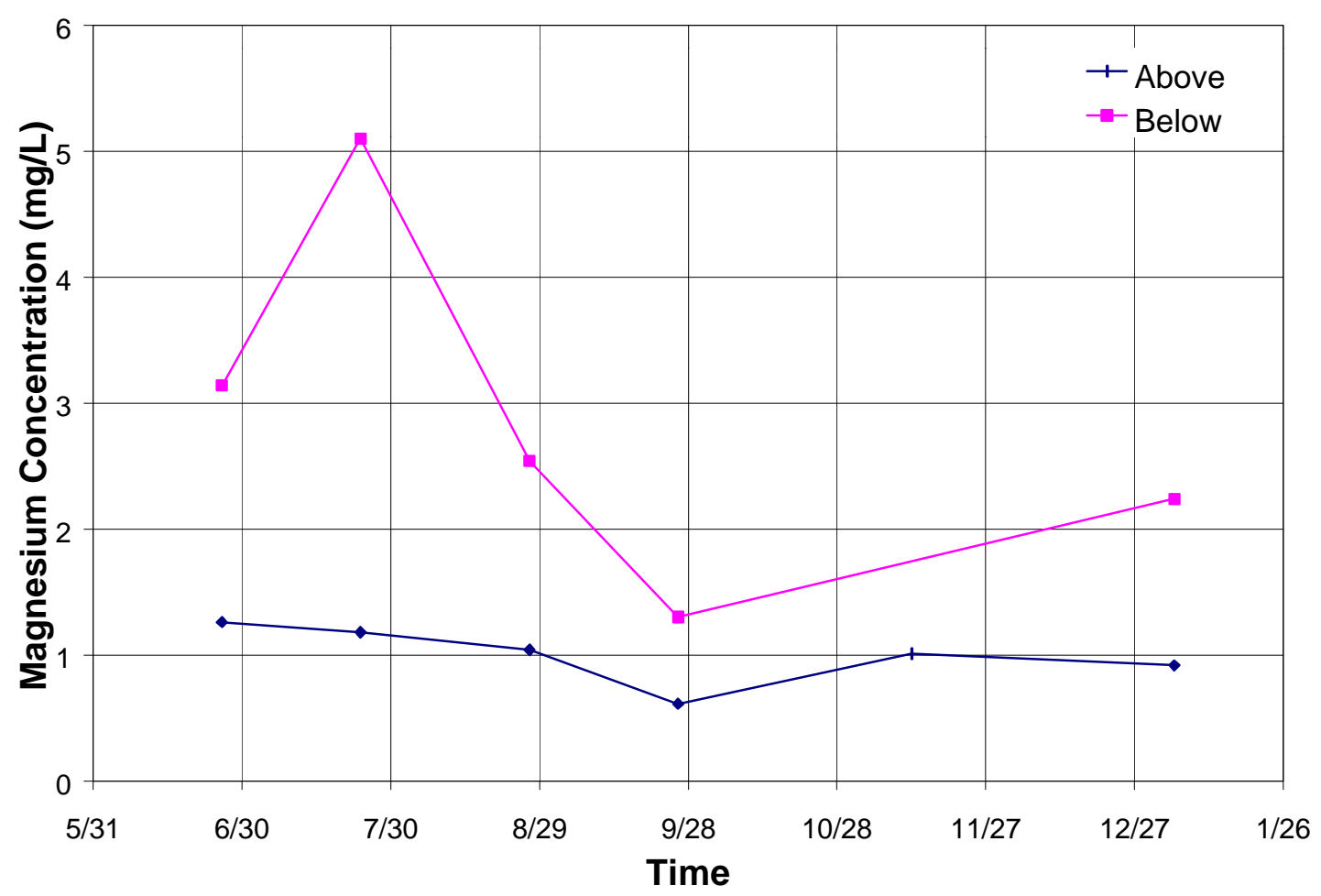

Figure 5.14. Magnesium Concentration Above and Below the Spoils Pile. 
Hypothetically, runoff from the spoils pile would be expected to create an increase in downstream total suspended solids due to erosion (Barrett et al. 1998b). The total suspended solids concentrations were believed to increase as the ditch line collected runoff from the spoils pile. However, with the exception of June 26, 2000, the total suspended solids concentration above and below the spoils pile did not vary greatly, as presented in Figure 5.4. While the percent differences between total suspended solids above and below the spoils pile were high (74\% for July, $48 \%$ for September, and 54\% for January), the concentrations were low (an average of $8.82 \mathrm{mg} / \mathrm{L}$ above and $16.1 \mathrm{mg} / \mathrm{L}$ below), with the exception of June 2000 data. In June, the total suspended solids concentration increased $41 \%$ from $268 \mathrm{mg} / \mathrm{L}$ above the spoils pile to $488 \mathrm{mg} / \mathrm{L}$ below the spoils pile. Figure 5.1 was a graphical representation of turbidity, which neither increased nor decreased from above to below the spoils pile by more than 10\%. A trend similar to that observed for total suspended solids was noticed in turbidity, where high turbidity measured at both sites in June followed by an average turbidity above spoils of 9.67 NTU and below the spoils pile of 11.2 NTU.

Metal concentrations (i.e., iron, manganese, and aluminum) were another concern below the spoils pile. Comparatively, as demonstrated in Figure 5.2 through 5.14, the site sampled above the spoils pile had higher alkalinity concentrations, lower metal concentrations, higher $\mathrm{pH}$, and lower conductivity for all the months sampled. As presented in Figures 5.2, 5.3, 5.5, and 5.6, a distinct difference in $\mathrm{pH}$, conductivity, alkalinity, and acidity, respectively, existed between the above and below sites. As a result of low stream flow at the site below the spoils pile, a sample was not collected during the month of November, therefore a comparison could not be made between the 
two sites for November. Chloride concentration was generally low, less than $3.5 \mathrm{mg} / \mathrm{L}$. In August and September, above and below had equal concentrations of chloride, therefore the spoils pile was not suspected to be a source of chloride. The iron trend appeared to be similar to that of the total suspended solids concentration and the turbidity, high in June, then low and approximately equal at both sites in subsequent samplings. The percent changes for sulfate, manganese, aluminum, and magnesium from above to below the spoils pile are presented in Table 5.1.

Table 5.1. Percent Change Between Sulfate, Manganese, Aluminum, and Magnesium from Above to Below the Spoils Pile.

\begin{tabular}{|c|c|c|c|c|}
\hline Month & Sulfate, $\%$ & Manganese, $\%$ & Aluminum, $\%$ & Magnesium, $\%$ \\
\hline June & --- & $\mathbf{7 7}$ & $\mathbf{3 7}$ & $\mathbf{5 9}$ \\
\hline July & $\mathbf{9 0}$ & $\mathbf{9 5}$ & $\mathbf{9 5}$ & $\mathbf{7 6}$ \\
\hline August & $\mathbf{7 7}$ & $\mathbf{9 0}$ & $\mathbf{9 2}$ & $\mathbf{6 1}$ \\
\hline September & $\mathbf{6 9}$ & $\mathbf{5 6}$ & $\mathbf{8 7}$ & $\mathbf{5 7}$ \\
\hline January & $\mathbf{5 0}$ & $\mathbf{8 2}$ & $\mathbf{1 1 0}$ & $\mathbf{5 9}$ \\
\hline
\end{tabular}

${ }^{1}$ Sulfate concentration not determined on this date, as an insufficient amount of sample was collected for full assay.

A paired t-test was conducted in order to assess the potential for random variability between water quality data collected above and below the spoils pile (Yousef et al. 1982) and to test the initial hypothesis based on the "visual" inspection of the data. The results of the paired t-test for data collected above and below the spoils pile are presented in Table 5.2. 
Table 5.2. Results of Paired t-Test Conducted Above and Below the Spoils Pile.

\begin{tabular}{|c|c|c|c|c|}
\hline Parameter & $\begin{array}{c}\text { Observed } \\
\text { Trends }\end{array}$ & $\begin{array}{c}\text { Normality } \\
\text { Test }\end{array}$ & $\begin{array}{c}\text { Paired t-Test } \\
\text { Statistic }\end{array}$ & $\begin{array}{c}\text { Statistically } \\
\text { Significant } \\
\text { Relationship? * }\end{array}$ \\
\hline Turbidity & $\Leftrightarrow$ & Passed & -0.435 & No \\
\hline pH & $\Downarrow$ & Passed & 4.74 & Yes \\
\hline Conductivity & $\Uparrow$ & Passed & -2.31 & Yes \\
\hline $\begin{array}{c}\text { Total Suspended } \\
\text { Solids }\end{array}$ & $\Leftrightarrow$ & Failed & -1.13 & No \\
\hline Alkalinity & $\Downarrow$ & Passed & 5.44 & Yes \\
\hline Acidity & $\Uparrow$ & Passed & $-\mathbf{2 . 8 4}$ & No \\
\hline $\begin{array}{c}\text { Particle Size } \\
\text { Analysis }\end{array}$ & $\Leftrightarrow$ & Passed & 0.127 & Yes \\
\hline Iron & $\Leftrightarrow$ & Passed & -1.01 & No \\
\hline Sulfate & $\Uparrow$ & Passed & -2.53 & No \\
\hline Chloride & $\Leftrightarrow$ & Passed & -1.71 & No \\
\hline Calcium & $\Leftrightarrow$ & Passed & -1.27 & Yes \\
\hline Total Hardness & $\Leftrightarrow$ & Passed & -1.80 & Yes \\
\hline Magnesium & $\Uparrow$ & Passed & -3.39 & -2.77 \\
\hline Manganese & $\Uparrow$ & Passed & -3.73 & \\
\hline Aluminum & $\Uparrow$ & Passed & - & \\
\hline
\end{tabular}

*Statistically significant relationship existed between above and below if $|t|>2$.

Given the outcomes from the paired t-test, a statistical difference between the sites above and below the spoils pile existed for the following parameters: $\mathrm{pH}$, conductivity, alkalinity, acidity, sulfate, magnesium, manganese, and aluminum. A statistical difference did not exist for the total suspended solids and turbidity, at the two sites. Thus, the spoils pile was determined to be a source of water quality impairment as metal concentrations exceeded the standards presented previously in Table 4.1.

Based on results of the benthic macro invertebrate assessment performed on the sites above and below the spoils pile (Sites 2a and 2b) it was determined that water impairment was created by the spoils pile. The number of individuals decreased from an average of 104 above the spoils pile, to 23 below the spoils pile, a $78 \%$ decrease. The percent EPT, which decreases with an increase in water impairment, declined $16 \%$, from 
$85 \%$ above to $71 \%$ below the spoils pile. The percentage of filterers to shredders increased from $24 \%$ to $111 \%$, above to below the spoils pile, respectively, an increase of $363 \%$. No fish were found at either site after electro shocking the stream. Since fish were not found at either site, the impact of the spoils pile on fish could not be established. However, Portele et al. (1982) reported that either the suspended solids levels or the pollutants associated with the solids can cause mortality of the fish, even though the suspended solids levels were lower than values normally considered harmful to fish.

The average WVSCI above the spoils pile was 75 (classified as "good", almost "very good") and the average WVSCI below the spoils pile was 59 (classified as "fair"). Consequently, a decline in benthic macro invertebrates of $21 \%$ was determined. Based on WVSCI scores alone, the impact of impaired waters from the spoils might be under emphasized, as a decrease in water quality from "good" to "fair" may not "sound an alarm." Further, HBI and WVSCI scores are based only on the assessment of specific species (Ephemeroptera, Plecoptera, Trichoptera, and Chironomidae). As a result, there may be more broad-based impacts of water quality on biological communities which are not gauged by the assessment of index scores alone. However, the average wet biomass decreased from $1.6 \mathrm{~g}$ above the spoils pile to $0.2 \mathrm{~g}$ below the spoils pile, which was an $88 \%$ decrease.

Based on the water quality and benthic macro invertebrate assessment, the spoils pile was determined to be a source of impairment. Barrett et.al. (1995c) observed that particulates and sediment in runoff can cause problems by decreasing flow capacity in drainage ways, reducing storage volume in ponds and lakes, smothering benthic macro invertebrates, decreasing water clarity, and interfering with the respiration of small fish. 
HBI and WVSCI scores are a measure of particular benthic macro invertebrate species and can therefore be misleading; to remedy this, it is recommended that the wet biomass and water quality parameters should be determined in addition to the HBI and WVSCI scores. Further, it is recommended that Laurel Run be continuously monitored before and after remediation to gauge any changes in environmental conditions.

\subsubsection{Remediation Techniques for Spoils Piles}

Through the examination of the water quality above and below the spoils pile and the changes in biological productivity, the spoils pile was determined to be a source of impairment in the Laurel Run drainage basin, thus, mitigation is recommended. The contaminant and metal loading trend is likely similar to conditions at other roadway construction sites in West Virginia and the Mid-Appalachian Region and the spoils pile on Laurel Run can be used as a model for impact avoidance and/or remediation in future construction projects.

Through an extensive review of existing literature, several remediation techniques, appropriate to ameliorate current conditions at Laurel Run, have been identified and are presented in subsequent subsections.

\subsubsection{Revegetation}

One method of remediation is revegetation. Revegetation attempts were made on the spoils pile with a seed mix of wheat, rye, and fescue grasses, however, the acidic soil and the presence of groundwater seeps were not conducive to plant growth. However, species of algae and moss were found to thrive on the site. Sphagnum spp. and 
Oscillatoria spp. or blue-green algae are species which prefer acidic conditions (Sengupta 1993) for growth and could potentially become the frontrunners for remediation and metal uptake. It is recommended that in roadway construction operations, fresh topsoil and mulch mixed with straw should be placed over spoils or stock piles in order to promote seed germination and to ensure the newly planted seed will not be washed off with the first intense rain event. Barrett et al. (1995c) observed that where sufficient soil thickness is present, natural processes occurring in soils can attenuate pollutants in highway runoff prior to reaching the groundwater. Kobriger and Geinopolos (1984b) supported this finding by reporting that metal concentrations were generally higher in topsoil layers than in substrate layers, but the filtration process varied in effectiveness with different soil types.

Soil losses from erosion may be inconsequential when compared to the damage resulting from sediment transport and deposition into surface waterways. Fish spawning areas and benthic macro invertebrate habitats may be destroyed or damaged when sediment deposition covers stream and river bottoms. Suspended solids also reduce light transmission, which limits in-stream photosynthesis and diminishes aquatic food supply and habitat (Barrett et al. 1995c, Portele et al. 1982).

Chisholm and Downes (1978) recorded the effects of the construction of the Appalachian Corridor $G$ highway on the benthic population of a stream receiving construction runoff, which included severe depletion or destruction of the biological community. However, within one year, rapid repopulation and stabilization of the biological community had occurred due to revegetation and slope grading. It is recommended that the spoils pile be revegetated with aims of facilitating recovery of the 
benthic macro invertebrate communities.

Revegetation practices such as temporary seeding, sod stabilization, permanent seeding and planting, buffer zone, and preservation of natural vegetation are commonly implemented. Vegetative covers can be preexisting or planted after the construction process has been completed. Vegetation minimizes erosion potential, protects water quality, and provides aesthetic benefits. Revegetated piles should control sedimentation and provide filtration of solids and plant uptake of dissolved organics and inorganics. These processes are promoted by intimate and extended contact between runoff flow and vegetation, which require a close-growing cover of water-resistant grassy species (Dodson 1999, Horner 1985, Schueler and Lugbill 1990). Construction can be destructive to the natural vegetation; therefore site-specific preventive measures must be employed (Dodson 1999).

Wright et al. (1976) determined that stair-step grading, producing a rough, loose surface provided an ideal environment for fast germination, growth, and plant succession. Plant growth was reported to be stronger on fill slopes than on cut slopes due to less compaction of the rock and soil. Recommended legume species for soils with low $\mathrm{pH}$ and low organic material content were crownvetch, sericea, and flat pea.

Revegetation may also be combined with waste pile capping. When highway excavation exposes pyretic shale material which leaches waters with low $\mathrm{pH}$ (4.0 to 4.4) and elevated metal concentrations, permanent mitigation is required, as with the spoils pile. Yew and Makowski (1989) suggested sealing the exposed mine spoils from surface water infiltration with a lime and topsoil cap. 


\subsubsection{Wetland Treatment Systems}

Further remediation of the spoils pile could include the implementation of a wetland to treat acidic runoff and drainage. A wetland would provide a mechanism to simultaneously reduce the sediment loading to Laurel Run, decrease dissolved metal concentrations, and slow the runoff waters before reaching the stream. Before alkalinity can effectively increase the $\mathrm{pH}$ of the water, the acidity in the water must be neutralized, there the wetland must have the capability to treat acidity. However, wetlands require an allotted amount of land and such excess space is not available near the spoils pile, therefore, a wetland would not be a feasible method of remediation at this site unless water was conveyed to a remote treatment location.

If a wetland were to be constructed at future sites similar to Laurel Run, the most efficient form would be either: (1) a combination of anaerobic and aerobic wetlands or (2) anoxic limestone drain (limestone lined stream) followed by an aerobic wetland to impart alkalinity to the water and to increase the $\mathrm{pH}$ of the influent water of the wetland (Sikora et al. 1996, Wieder 1988). The recommended vegetation would be either Typha spp or Sphagnum spp. moss on a bed of limestone and peat or other organic rich substrate such as mushroom compost, manure, or wood chips (Vile and Wieder 1993, Murawski 1994, Sengupta 1993, Faulkner and Skousen 1994). However, additional research is recommended to identify specific substrates which are both technically and economically feasible for the treatment of acidic runoff water for the specific case of waters in the vicinity of highways in West Virginia. Factors that limit the success of wetland establishment include improper grade, improper wetland species, inadequate water level, erosion, and litter deposition and accumulation (Thrasher 1983). 
In aerobic wetland systems, the major mechanism of metal removal is chemical precipitation of oxyhydroxides and organic compounds. Oxygen is present, which aids in the precipitation of metal oxides (Faulkner and Skousen 1994). Anaerobic wetlands are composed of organic rich substrates and are devoid of oxygen. The metal removal occurs as a result of the metabolic activity of heterotrophic and autotrophic sulfur reducing bacteria living in the nutrient laden substrate. Treatment occurs through interactions within the organic carbon rich substrate. Metal oxidation in the anaerobic wetland takes place in the anaerobic layers and through microbial reduction reactions, which also neutralize the $\mathrm{pH}$. The high biochemical oxygen demand (BOD), produced by the organic carbon rich substrate, causes the water to become anaerobic as it passes through the wetland (Faulkner and Skousen 1994).

A combination of aerobic and anaerobic zones may also be applied, typically onethird aerobic and two-thirds anaerobic. The entire wetland, typically constructed, is underlain with limestone to produce alkalinity. Alkalinity may also be generated by the reduction of sulfate to sulfides and from the continuous dissolution of calcium carbonate under anoxic sediment conditions (Calabrese et al. 1991).

The size of the wetland constructed is dependent upon the specific amount of metal removal required and the acid content of the water filtering through the substrate. A comparison of anaerobic and aerobic wetlands is presented in Table 5.3. 
Table 5.3. Comparison of Anaerobic and Aerobic Wetlands (Skousen 2001).

\begin{tabular}{|c|c|c|c|c|}
\hline \multirow{2}{*}{ Wetland } & $\begin{array}{c}\text { Contaminant } \\
\text { Removed }\end{array}$ & $\begin{array}{c}\text { Removal Efficiency } \\
\text { for Acidic Waters } \\
\left(\mathrm{g} / \mathrm{m}^{2} / \mathrm{d}\right)\end{array}$ & $\begin{array}{c}\text { Removal } \\
\text { Efficiency for } \\
\text { Alkaline Waters } \\
\left(\mathrm{g} / \mathrm{m}^{2} / \mathrm{d}\right)\end{array}$ & $\begin{array}{c}\text { Cost } \\
\text { without plants } \\
\text { (in 1996 } \\
\text { dollars })\end{array}$ \\
\hline \multirow{2}{*}{ Anaerobic } & Acidity & $\mathbf{3 . 6}$ & $\mathbf{7 . 0}$ & $\mathbf{\$ 2 4 , 8 5 0}$ \\
\cline { 2 - 5 } Aerobic & Iron & $\mathbf{1 0 . 8}$ & $\mathbf{2 1 . 5}$ & $\mathbf{\$ 1 , 5 0 0}$ \\
\cline { 2 - 5 } & Acidity & $\mathbf{0 . 0}$ & $\mathbf{0 . 0}$ & $\mathbf{- -}$ \\
\hline \multirow{2}{*}{ Iron } & $\mathbf{0 . 0}$ & $\mathbf{2 1 . 5}$ & $\mathbf{\$ 1 , 5 0 0}$ \\
\hline
\end{tabular}

${ }^{1}$ Aerobic wetland does not remove acidity, therefore a cost for the wetland can not be determined.

Aerobic wetlands are best applied to alkaline waters, while anaerobic wetlands are able to treat both acidic and alkaline waters, and have acid removal rates of $7.0 \mathrm{~g} / \mathrm{m}^{2} / \mathrm{d}$ $\left(0.65 \mathrm{~g} / \mathrm{ft}^{2} / \mathrm{d}\right)$ as $\mathrm{CaCO}_{3}$ (Skousen 2001). The water at Laurel Run, Sites $1-4$, is net alkaline, thus an anaerobic wetland is recommended (Skousen 2001). Based an acidity content of $3231 \mathrm{~g} / \mathrm{d}$ as $\mathrm{CaCO}_{3}$, the area of an anaerobic wetland would be approximately $462 \mathrm{~m}^{2}\left(4970 \mathrm{ft}^{2}\right)$. This was calculated utilizing the maximum acidity concentration observed at Site $2 \mathrm{~b}, 18.7 \mathrm{mg} / \mathrm{L}$ as $\mathrm{CaCO}_{3}$, and the flow for this site of $0.002 \mathrm{~m}^{3} / \mathrm{s}$ or 1.73 x $10^{5} \mathrm{~L} / \mathrm{d}$. (An accurate flow measurement at this site could not be obtained for each sampling date due to intermittent flow through the drainage ditch.) An anaerobic wetland of this size would cost approximately $\$ 74,550$ (in 1996 dollars), which includes excavation, plants, limestone, compost, and pipes. Without the plants, the anaerobic wetland cost would be approximately $\$ 24,850$ (Skousen 2001).

If a reduction in iron concentration were the only removal necessary (maximum iron concentration at the site below the spoils pile was $3.45 \mathrm{mg} / \mathrm{L} ; 596 \mathrm{~g} / \mathrm{d}$ ) the anaerobic wetland with a typical iron removal rate of $21.5 \mathrm{~g} / \mathrm{m}^{2} / \mathrm{d}\left(2.0 \mathrm{~g} / \mathrm{ft}^{2} / \mathrm{d}\right)($ Skousen 2001) would be smaller than the anaerobic wetland used to treat the acidity alone (approximately $28 \mathrm{~m}^{2}, 300 \mathrm{ft}^{2}$ ). This would cost approximately $\$ 4,500$ for plants, 
excavation, limestone, compost, and pipes, compared to $\$ 1,500$ without the plants. By designing the anaerobic wetland for the treatment of iron and neglecting acidity, the net acidity in the water would still be decreased, as the ratio for iron treatment to acidity treatment is approximately 3:1 (Skousen 2001). A treatment wetland does not selectively treat water pollutants, thus as the iron is being removed, the acidity will be treated as well. In other words, a third of the acidity would be removed if the wetland were constructed solely for the treatment of iron (Skousen 2001). The cost of the aerobic wetland was not presented because the anaerobic wetland had a better combined removal efficiency of acidity and iron and was significantly less expensive.

\subsection{SEDIMENTATION PONDS}

\subsubsection{Upper Laurel Run}

The first sedimentation pond was positioned at "Camp Seefus," Site 4 as presented previously in Figure 3.1 (Upper Laurel Run). The back wall of this sedimentation pond has been "blown-out", likely due to excessive highway runoff and high flows created by rainstorms and can no longer impound water; therefore, it is not functioning as a sedimentation pond, could be classified as a wetland with typical wetland vegetation, such as Typha spp.

The blown out sedimentation pond/wetland at Upper Laurel Run could have created a large portion of the sediment loading observed at Laurel Run, however, the majority of the sediment has settled in the drainage basin or is entrapped in the wetland. When the back wall of the sedimentation pond washed out, the water carried with it the material used to initially impound it, a fraction of the sediment that was collected while 
the pond was functioning, and the eroded solids from the roadway slopes. The water quality of Upper Laurel Run is presented in Table 5.4.

Table 5.4. Water Quality Data of Upper Laurel Run.

\begin{tabular}{|c|c|c|c|c|c|c|}
\hline & June 19 & June 26 & July & September & November & January \\
\hline $\begin{array}{c}\text { Turbidity } \\
\text { (NTU) }\end{array}$ & 7.9 & 19.5 & 11.4 & 2.86 & 6.08 & 3.85 \\
\hline pH & 7.05 & 7.22 & 6.74 & 6.91 & 6.77 & 6.78 \\
\hline $\begin{array}{c}\text { Conductivity } \\
(\mu \mathrm{S} / \mathrm{cm})\end{array}$ & 182 & 176 & 178 & 156 & 108 & 78.2 \\
\hline TSS (mg/L) & 9.01 & N/A & 2.17 & 4.63 & 4.35 & 0.65 \\
\hline $\begin{array}{c}\text { Alkalinity } \\
\text { (mg/L as } \\
\mathrm{CaCO}_{3} \text { ) }\end{array}$ & 33.2 & 33.0 & 33.9 & 29.7 & 25.1 & 33.3 \\
\hline $\begin{array}{c}\text { Acidity } \\
(\mathrm{mg} / \mathrm{L} \text { as } \\
\left.\mathrm{CaCO}_{3}\right)\end{array}$ & 9.55 & 2.78 & 5.13 & 3.14 & 2.92 & 6.06 \\
\hline $\begin{array}{l}\text { Sulfate } \\
\text { (mg/L) }\end{array}$ & 84.3 & N/A & 37.2 & 40.1 & 19.4 & 39.1 \\
\hline Iron (mg/L) & 0.682 & 1.58 & 0.618 & 0.319 & 0.263 & 0.660 \\
\hline $\begin{array}{c}\text { Chloride } \\
\text { (mg/L) }\end{array}$ & 20.2 & N/A & 16.5 & 9.50 & 5.75 & 16.0 \\
\hline $\begin{array}{c}\text { Calcium } \\
(\mathrm{mg} / \mathrm{L} \text { as } \\
\left.\mathrm{CaCO}_{3}\right)\end{array}$ & 43.8 & N/A & 38.4 & 35.4 & 24.8 & 37.6 \\
\hline $\begin{array}{c}\text { Total } \\
\text { Hardness } \\
(\mathrm{mg} / \mathrm{L} \text { as } \\
\left.\mathrm{CaCO}_{3}\right)\end{array}$ & 63.2 & N/A & 58.2 & 53.6 & 36.4 & 57.4 \\
\hline $\begin{array}{c}\text { Manganese } \\
(\mathrm{mg} / \mathrm{L})\end{array}$ & N/A & 0.829 & 0.217 & 0.183 & BDL & 0.197 \\
\hline $\begin{array}{c}\text { Aluminum } \\
(\mathrm{mg} / \mathrm{L})\end{array}$ & N/A & 0.318 & BDL & 0.113 & BDL & BDL \\
\hline $\begin{array}{c}\text { Magnesium } \\
(\mathrm{mg} / \mathrm{L})\end{array}$ & N/A & 4.35 & 4.25 & 4.01 & 2.63 & 4.70 \\
\hline
\end{tabular}

N/A insufficient amount of sample collected to obtain meaningful results.

\subsection{2 "Intact" Sedimentation Pond}

The second sedimentation pond located along Laurel Run (Sites 3a and 3b) was 
believed to be a functioning basin. The water quality data above and below the sedimentation pond versus sampling date are presented graphically in Figures 5.15 through 5.28.

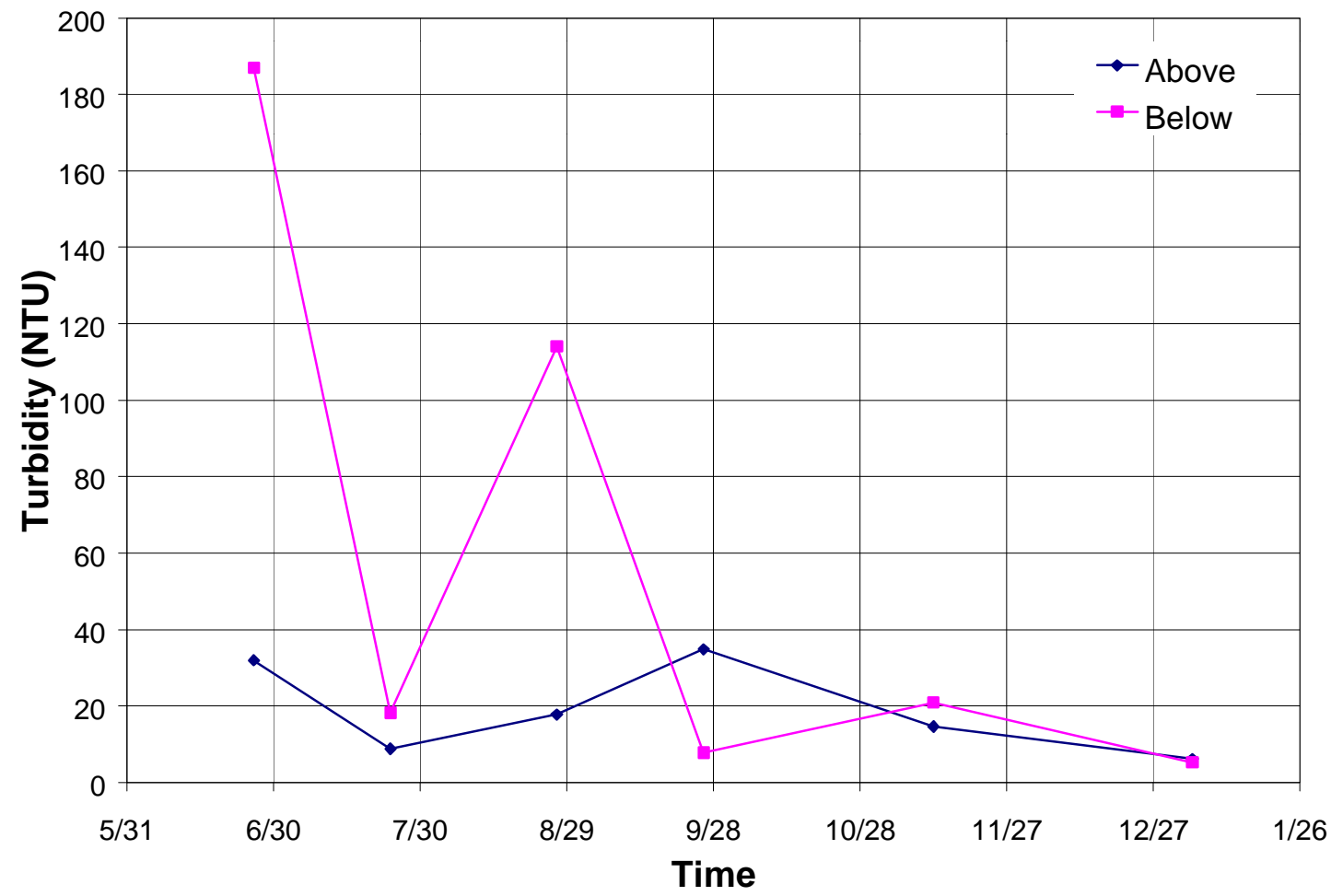

Figure 5.15. Turbidity Above and Below the Sedimentation Pond. 


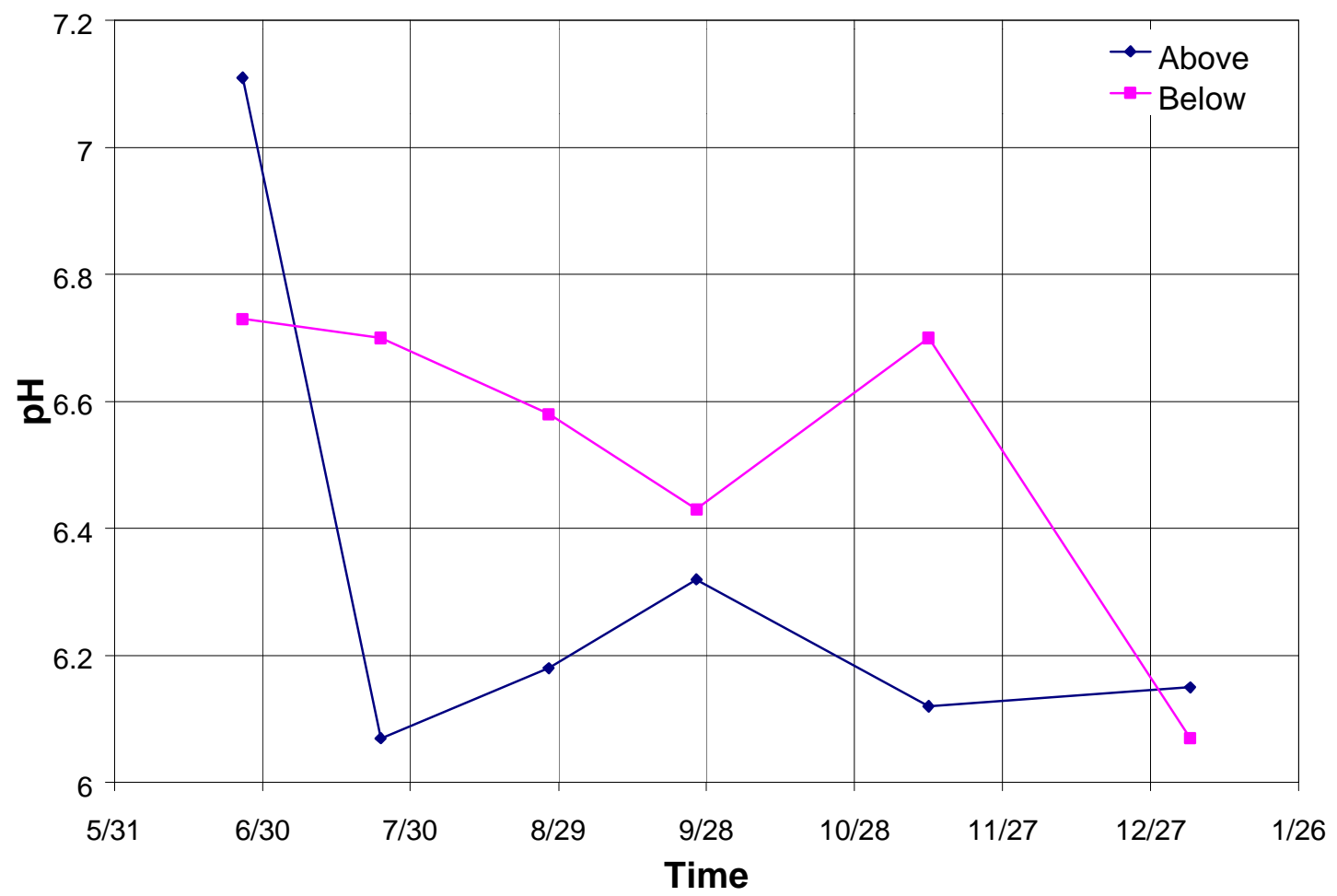

Figure 5.16. pH Above and Below the Sedimentation Pond.

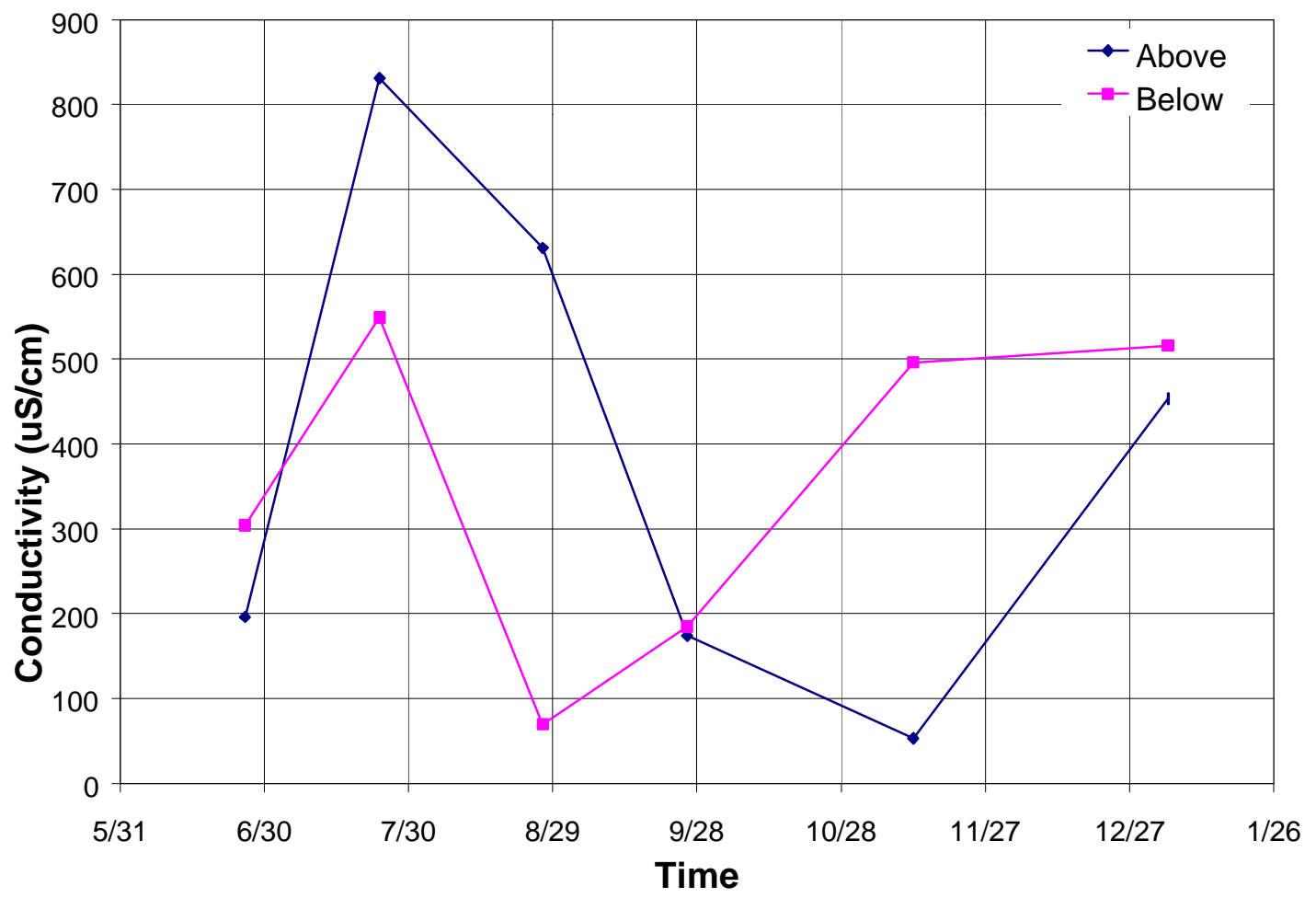

Figure 5.17. Conductivity Above and Below the Sedimentation Pond. 


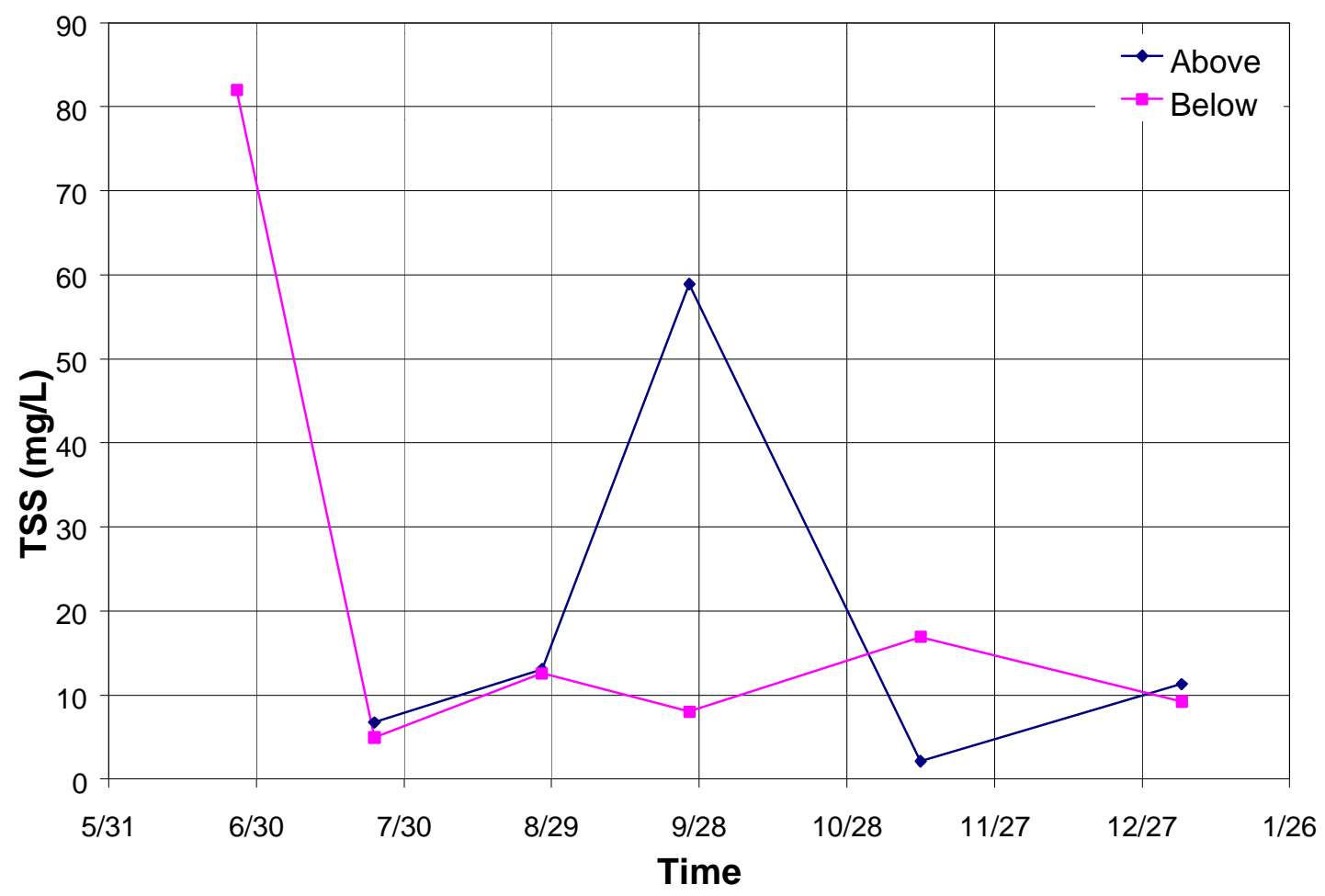

Figure 5.18. Total Suspended Solids Above and Below the Sedimentation Pond.

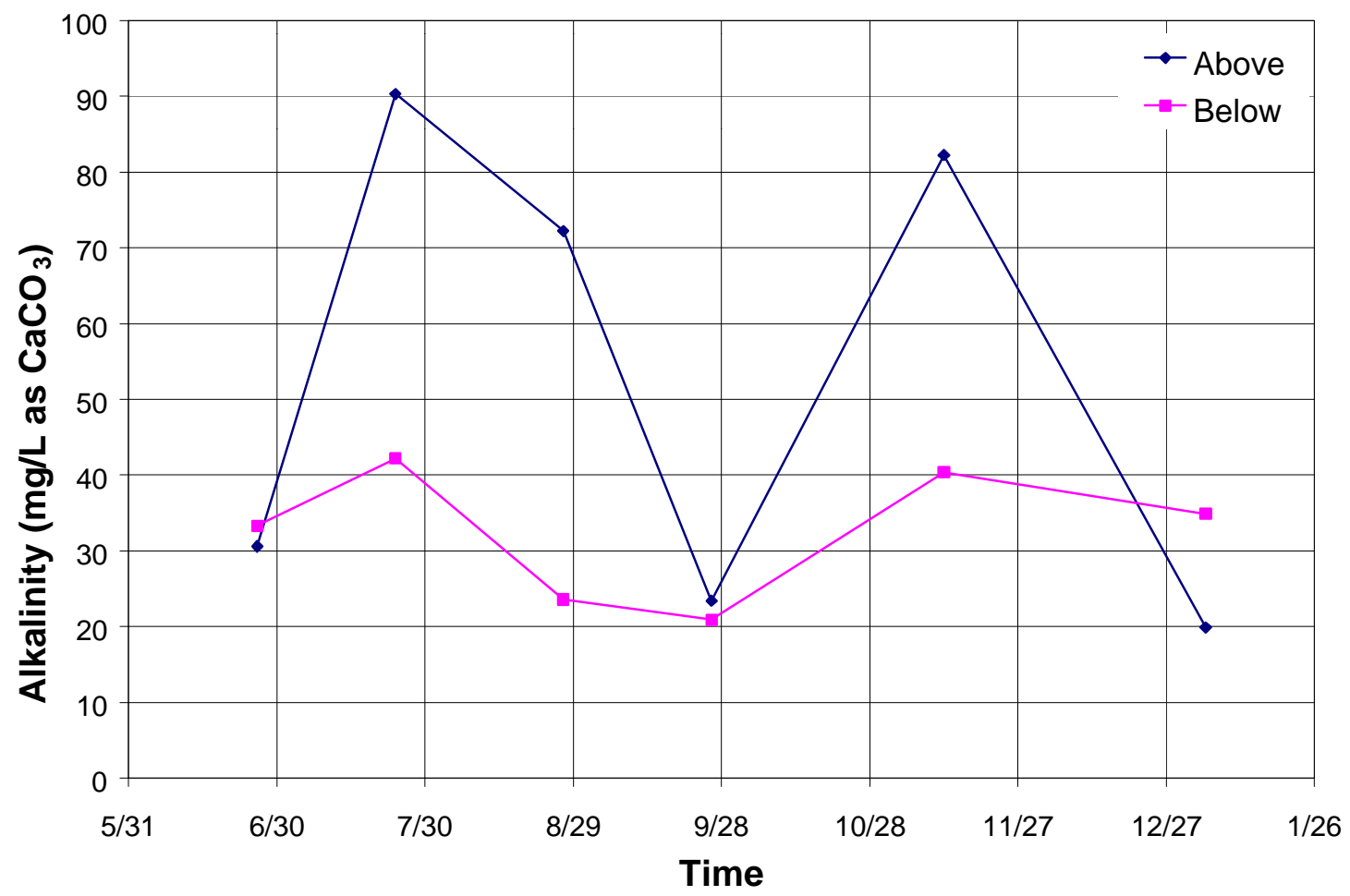

Figure 5.19. Alkalinity Above and Below the Sedimentation Pond. 


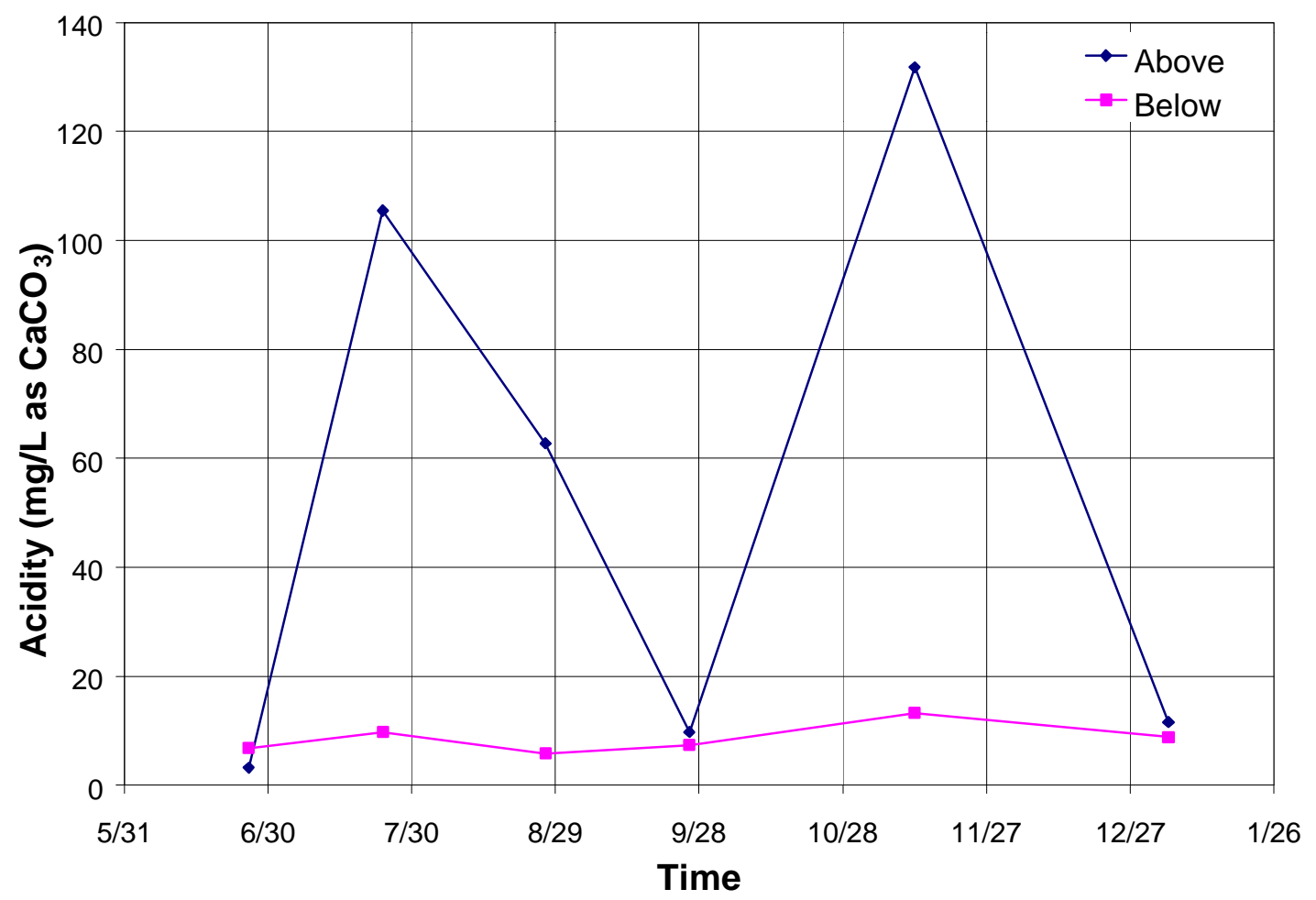

Figure 5.20. Acidity Above and Below the Sedimentation Pond.

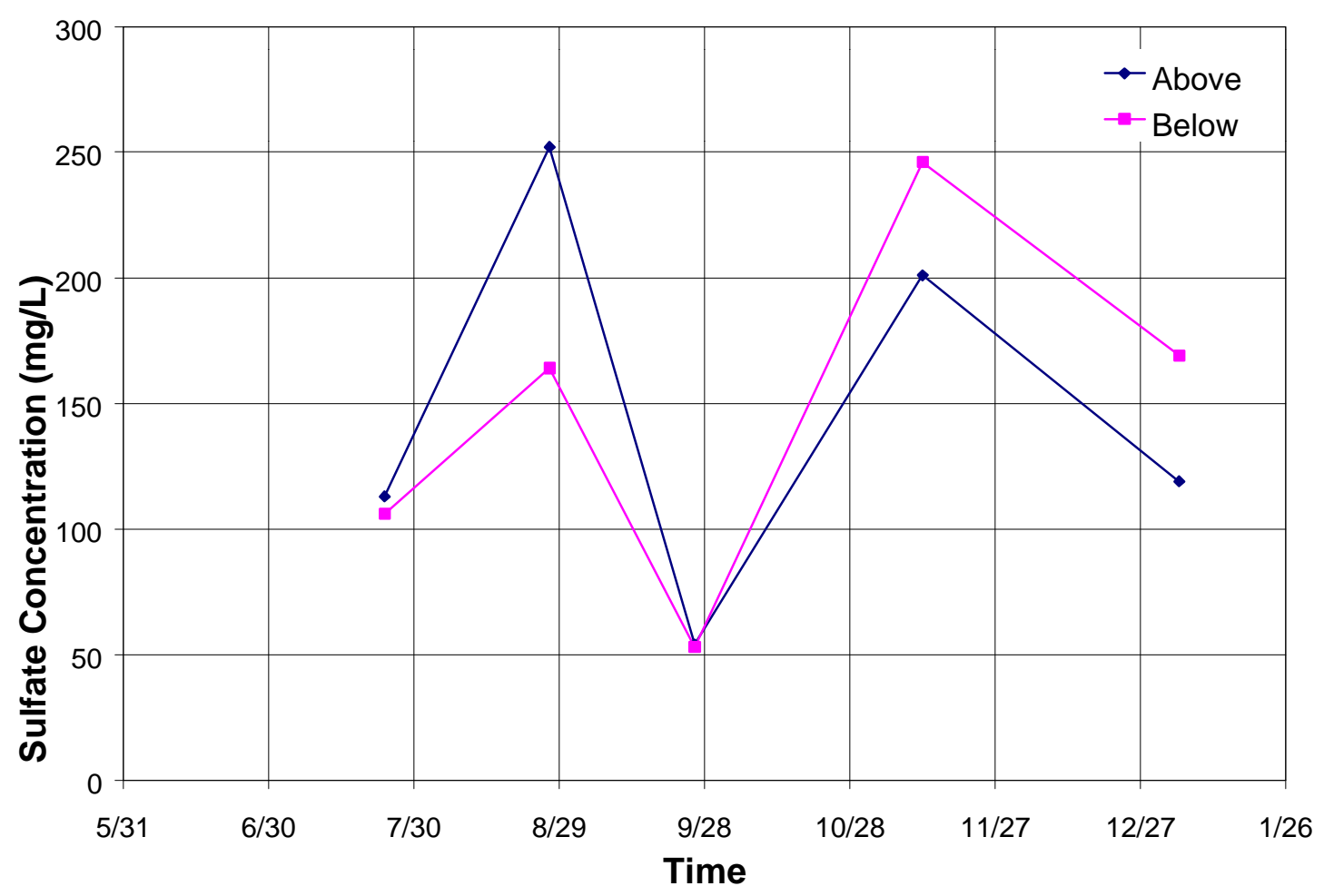

Figure 5.21. Sulfate Concentration Above and Below the Sedimentation Pond. 


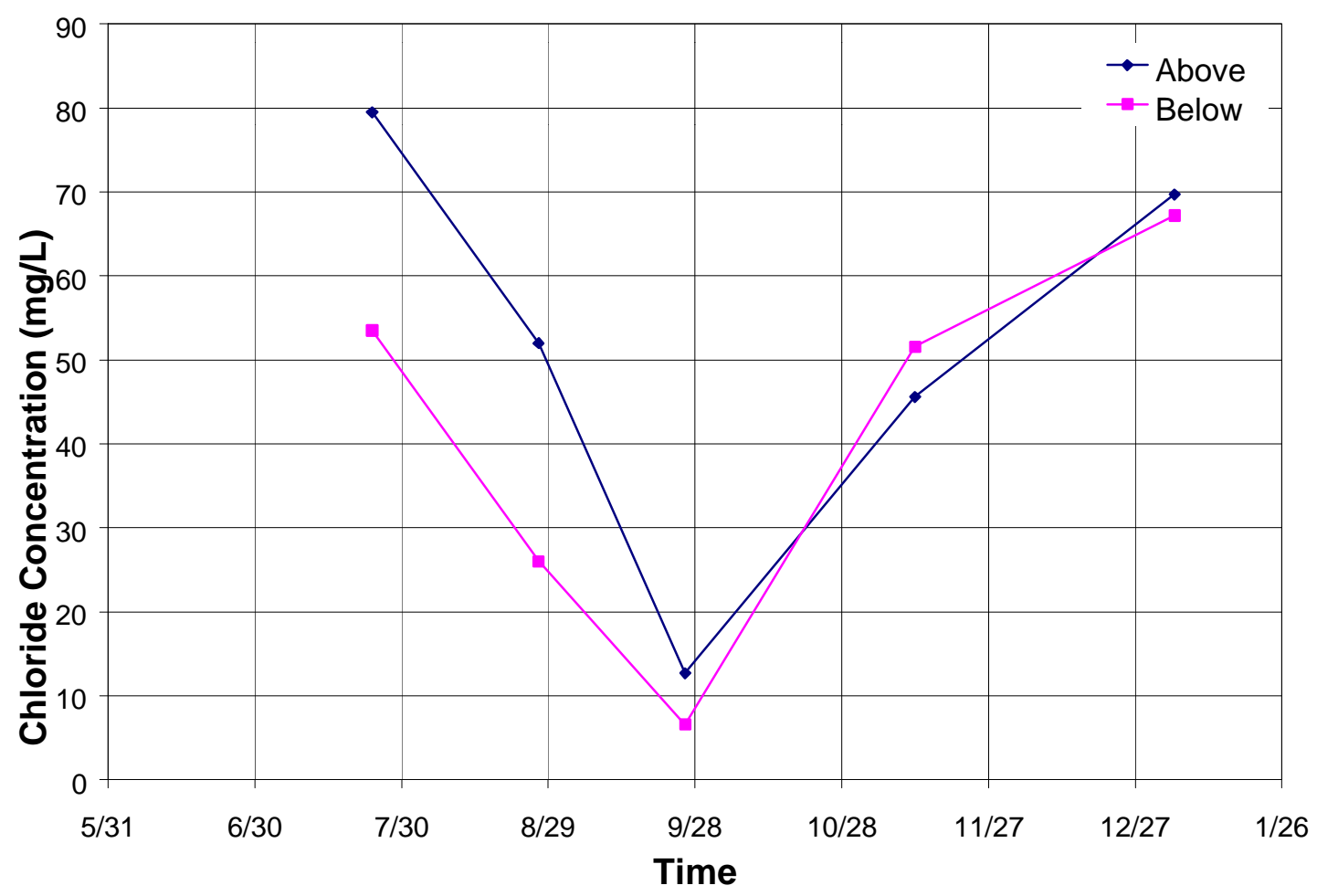

Figure 5.22. Chloride Concentration Above and Below the Sedimentation Pond.

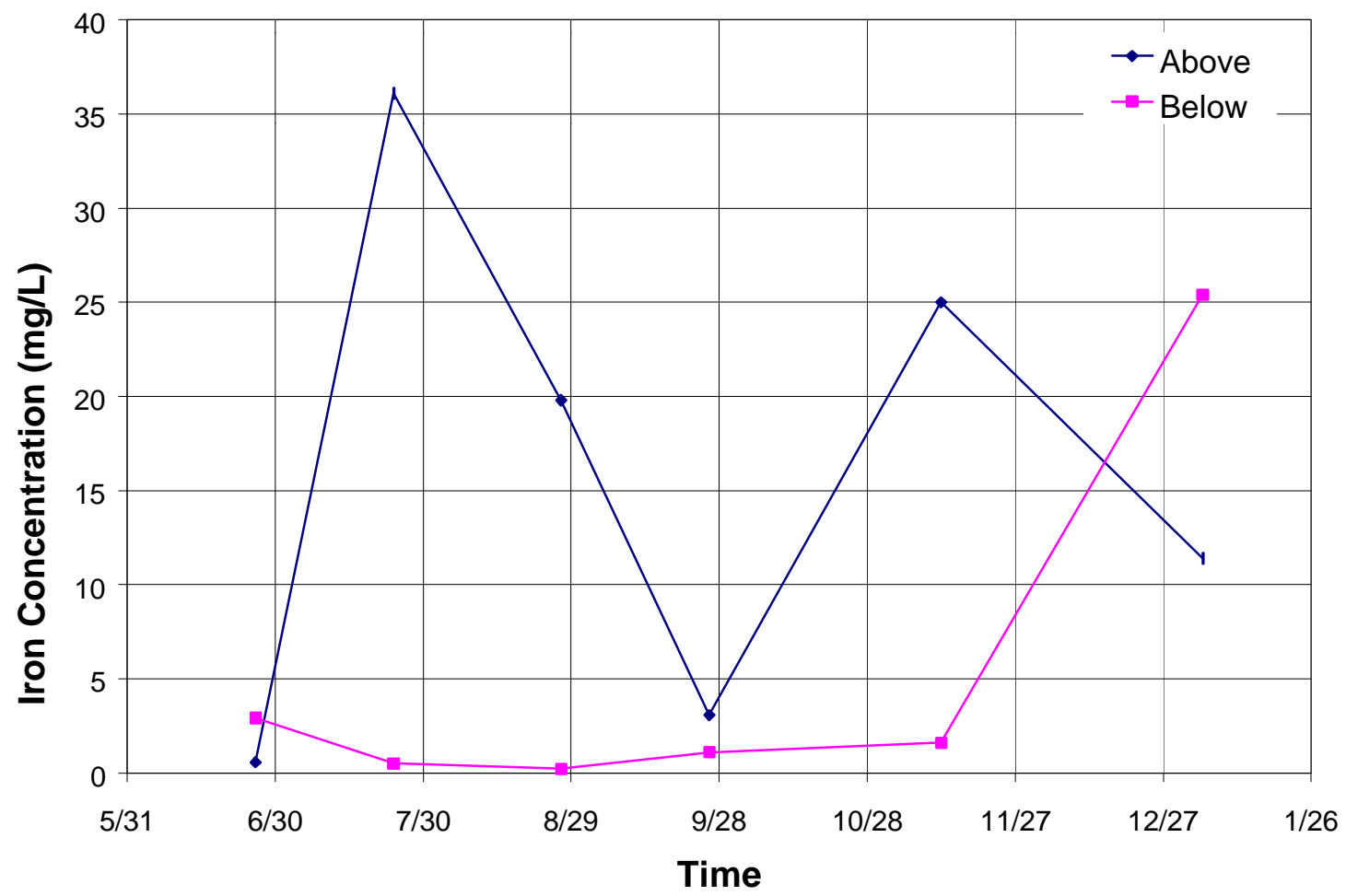

Figure 5.23. Iron Concentration Above and Below the Sedimentation Pond. 


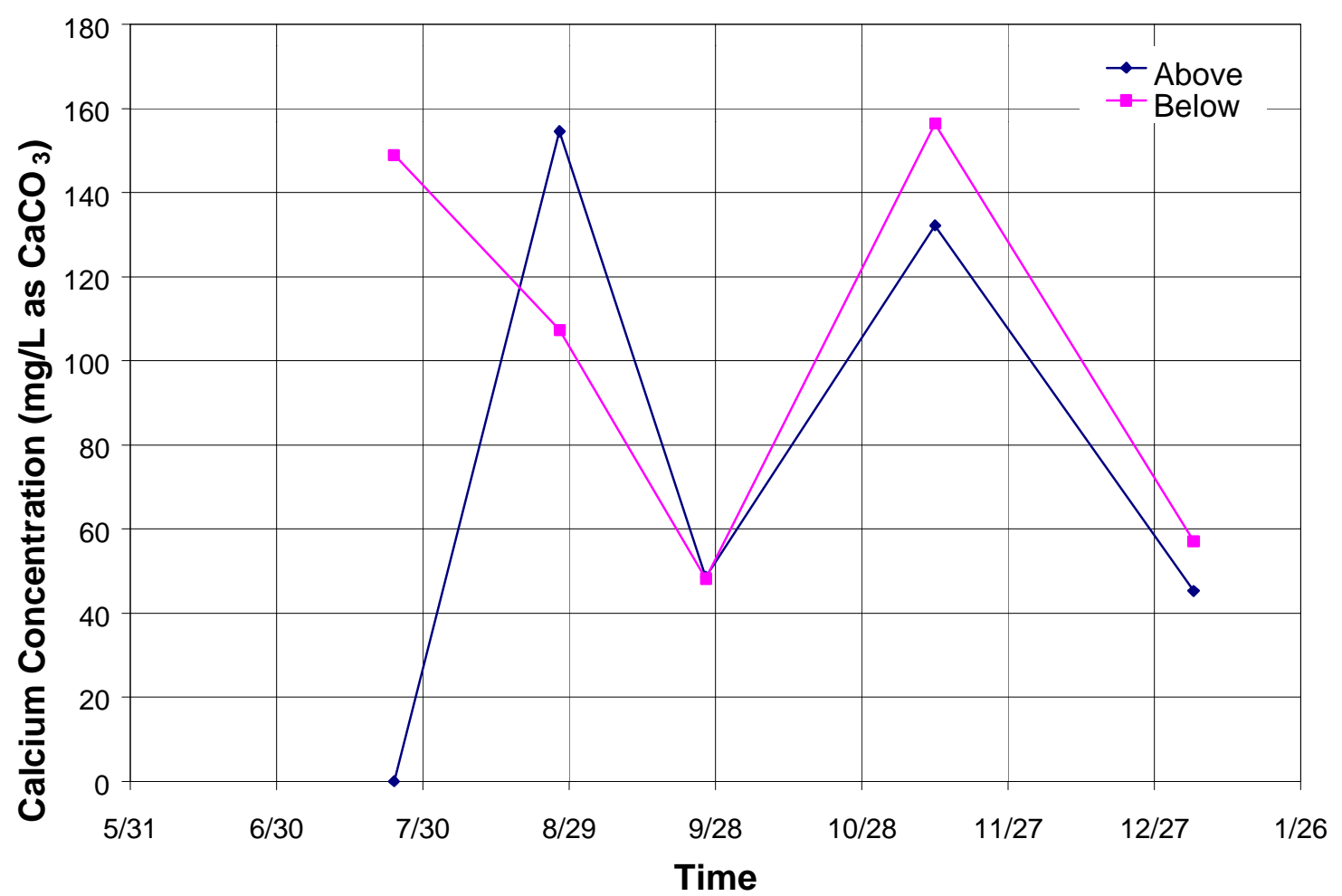

Figure 5.24. Calcium Concentration Above and Below the Sedimentation Pond.

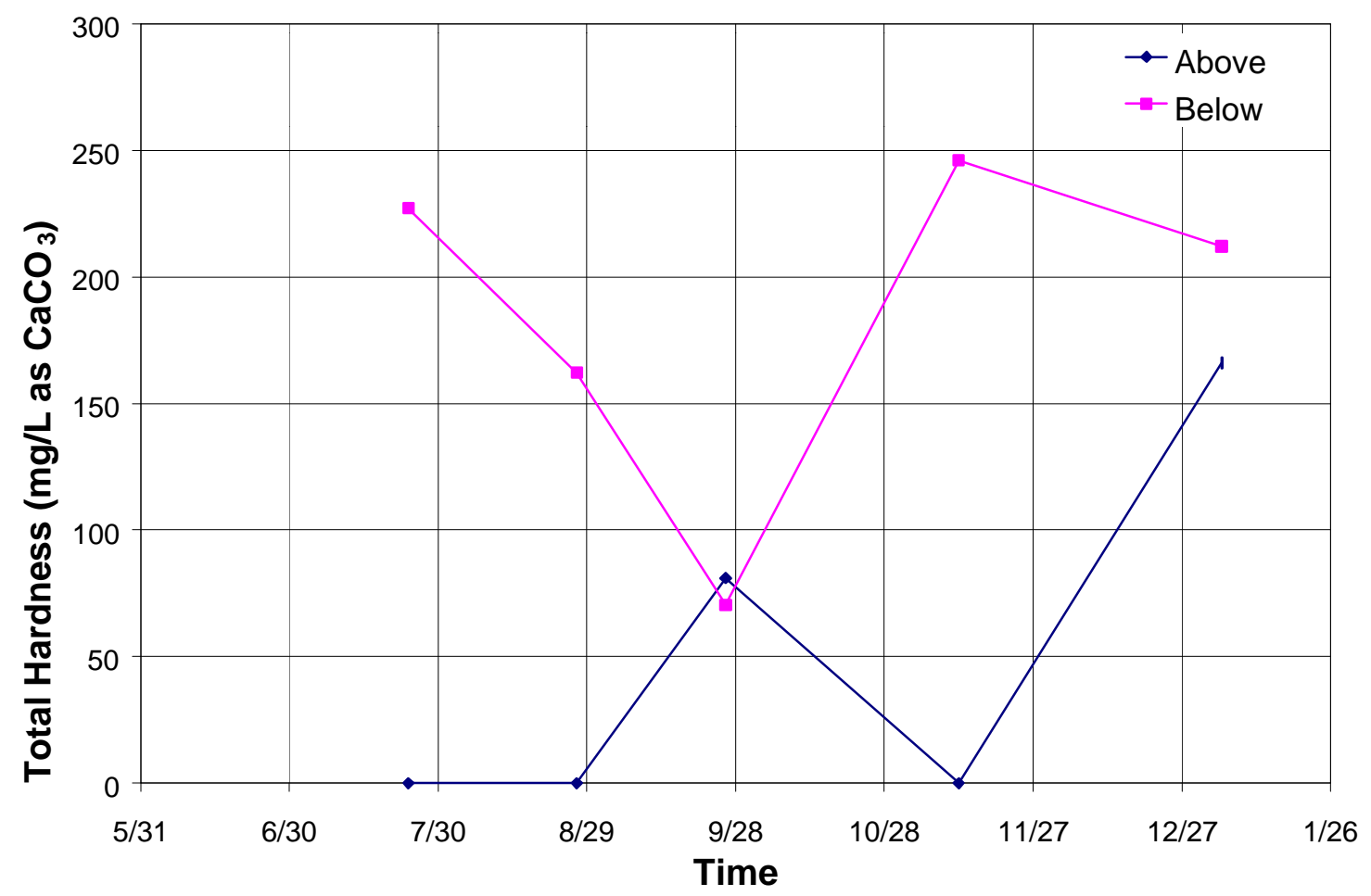

Figure 5.25. Total Hardness Concentration Above and Below the Sedimentation Pond. 


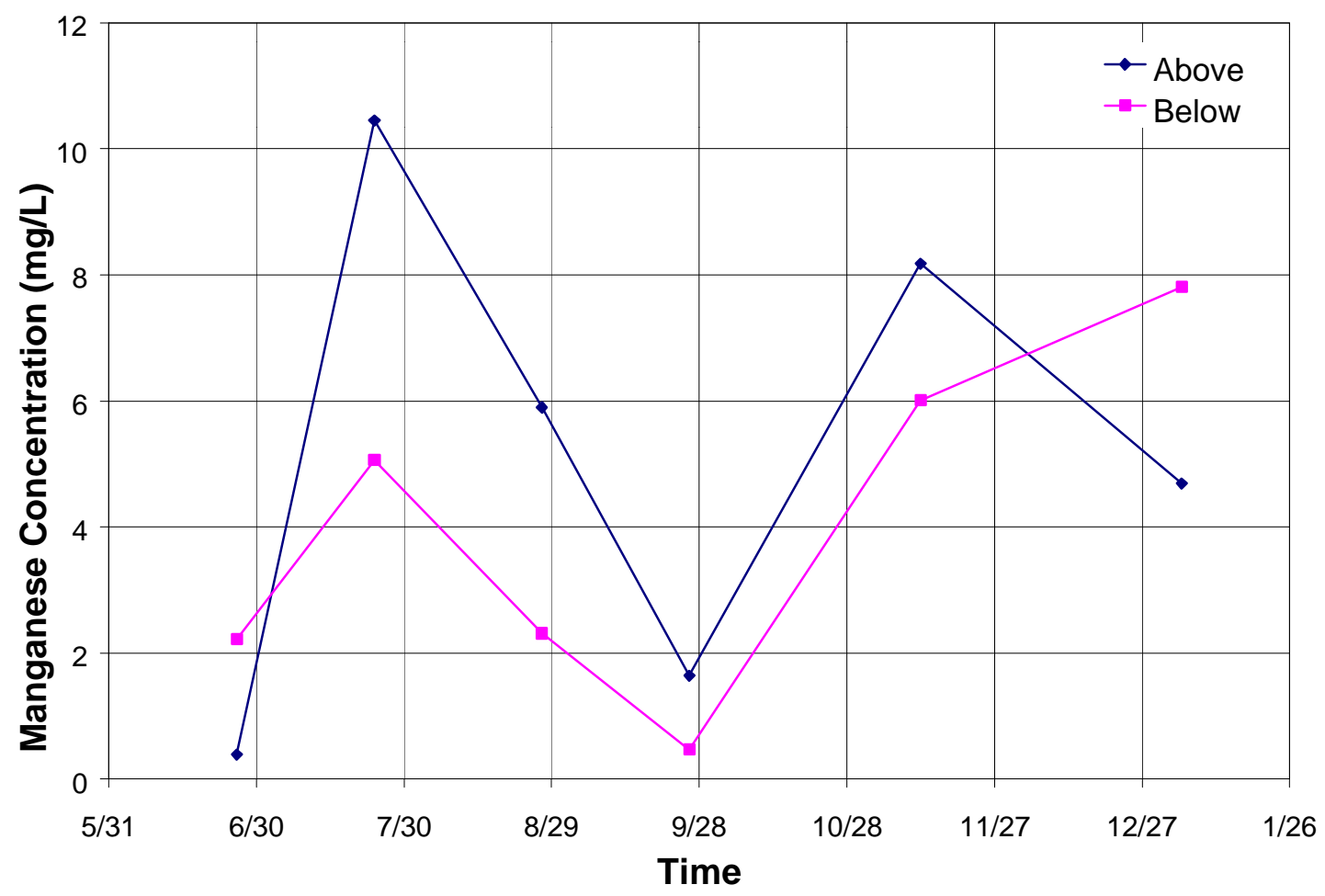

Figure 5.26. Manganese Concentration Above and Below the Sedimentation Pond.

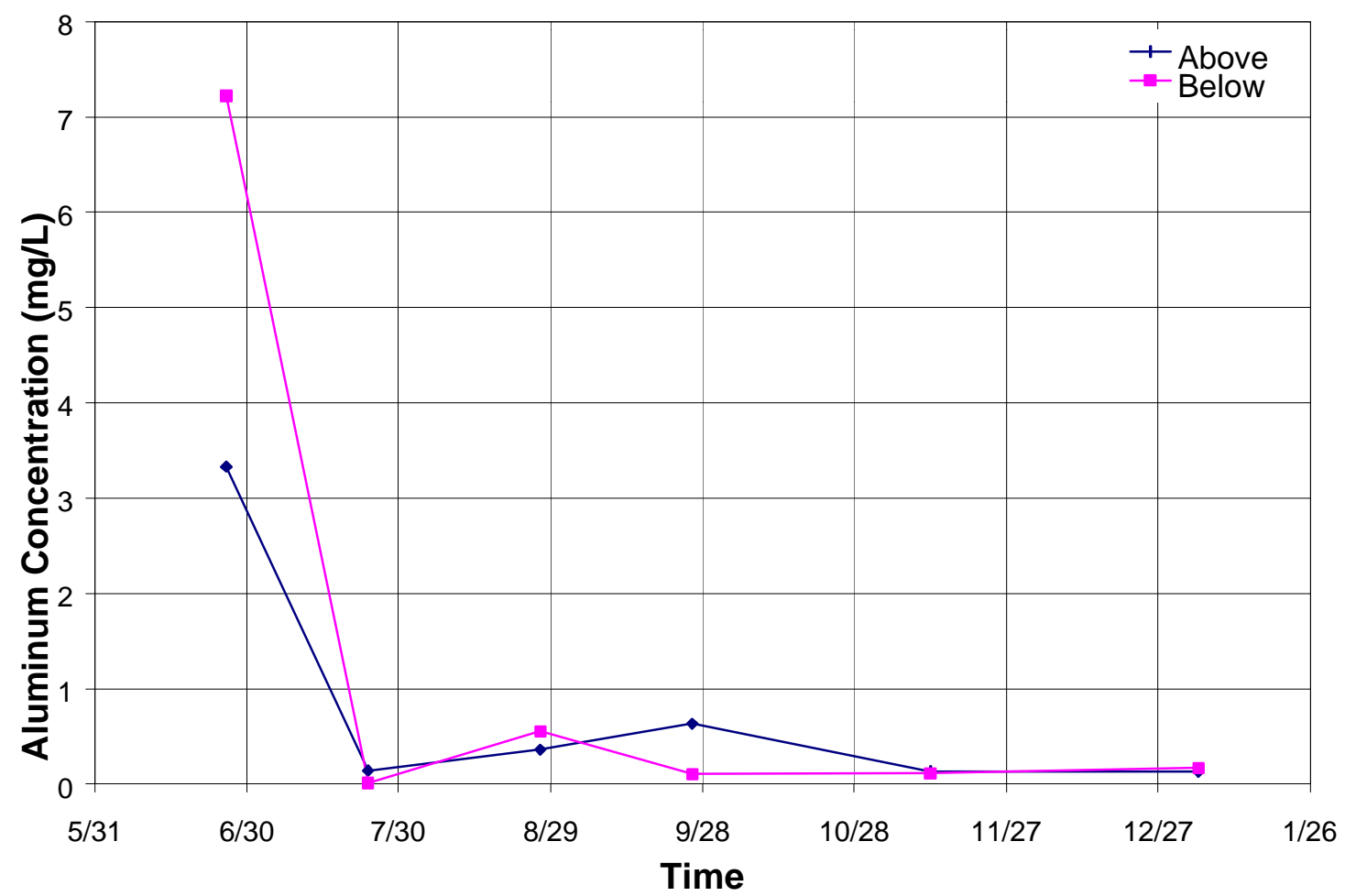

Figure 5.27. Aluminum Concentration Above and Below the Sedimentation Pond. 


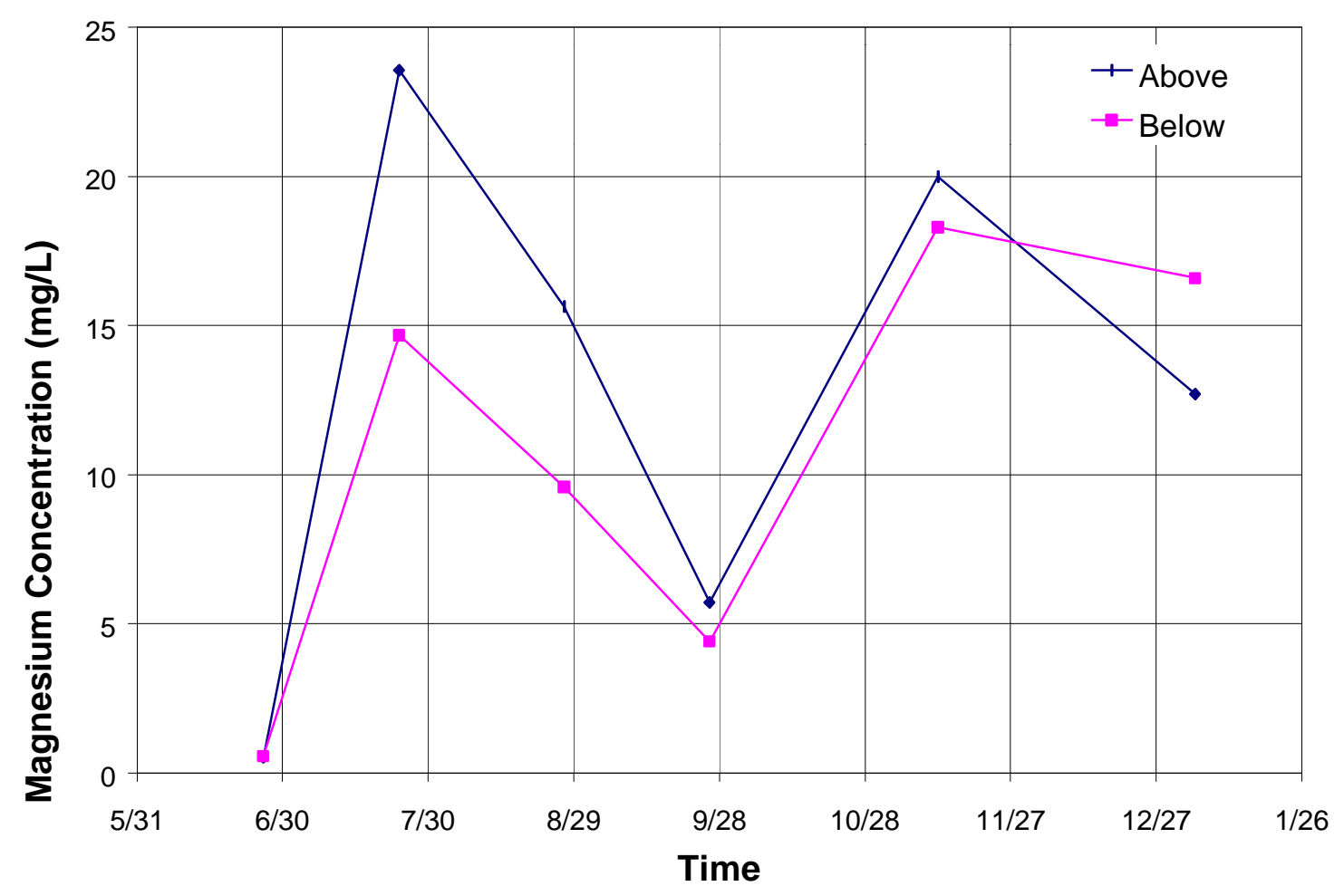

Figure 5.28. Magnesium Concentration Above and Below the Sedimentation Pond.

The mean particle diameters for above and below the sedimentation pond are presented in Table 5.5. The data collected above and below the sedimentation pond for the summer months were erratic. In July and August and September, total suspended solids concentration decreased from the influent to the effluent, which was indicative of a functioning sedimentation basin.

Table 5.5. Mean Particle Diameters for Above and Below the Sedimentation Pond.

\begin{tabular}{|c|c|c|c|c|c|c|}
\hline Site & June & July & August & September & November & January \\
\hline Above & 14.2 & $-{ }^{-}$ & 42.3 & 36.7 & $-{ }^{-}$ & $-{ }^{-}$ \\
\hline Below & 4.96 & 29.2 & 16.6 & $-{ }^{-}$ & 15.8 & -- \\
\hline
\end{tabular}

${ }^{1}$ No particle size data were reported for this sampling station during this month because particles were not dense enough for detection.

The months when insufficient particle density was reported were as significant as months with reportable particle size. Inconclusive particle size analysis results are 
indicative of possible two outcomes: the particles within the sample are below detection limit $(0.04 \mu \mathrm{m})$ or the amount of suspended particles within the sample are not great enough to be detected.

The turbidity fluctuated between the influent and the effluent; however, turbidity is a measurement of light scattered by all particles in solution and does not discriminate based on particle size. The smaller particles, not accounted for in the total solids concentration (which only measures particles greater than the filter pore size of $0.45 \mu \mathrm{m}$ ) were detected as turbidity.

Increased spikes were observed in the data for July, August, and November for alkalinity, acidity, and metal concentrations. The spikes were attributed to the decreased flow through the sedimentation pond, which resulted in higher concentrations. As flow data were not collected above or below the sedimentation pond, the decreased flow rate was based upon the determined flow at Lower Laurel Run, which was observed as being lower for July, August, and November. The percent change in water quality parameters from above to below the sedimentation pond is presented in Table 5.6.

Table 5.6. Percent Increase From Above to Below the Sedimentation Pond.

\begin{tabular}{|c|c|c|c|c|c|c|}
\hline Parameter & June & July & August & September & November & January \\
\hline Acidity, \% & 112 & 90.8 & 90.7 & 24.4 & 89.9 & 24.1 \\
\hline Alkalinity, \% & 8.8 & 53.3 & 67.3 & 10.7 & 50.9 & 75.4 \\
\hline Iron, \% & 419 & 98.6 & 98.9 & 64.1 & 93.6 & 123 \\
\hline Sulfate, \% & -- & 6.2 & 34.9 & 1.9 & 22.4 & 42.0 \\
\hline Manganese, \% & 471 & 51.6 & 60.8 & 71.5 & 26.5 & 66.5 \\
\hline Aluminum, \% & 117 & 92.9 & 53.2 & 83.4 & 15.3 & 28.0 \\
\hline Magnesium, \% & 12.4 & 37.7 & 38.7 & 22.9 & 8.5 & 30.7 \\
\hline
\end{tabular}

${ }^{1}$ Sulfate concentration not determined for this date as an insufficient amount of sample was collected for meaningful result. 
However, clear trends in acidity, alkalinity, iron, sulfate, manganese, aluminum, and magnesium were not readily discernable. It is postulated that the water in the sedimentation pond is moving as a plume, and the increased metal concentrations observed above the pond in August and September have shifted to the outlet where the results were similar to the results at inlet. Heavier sediments and pollutants, which had settled during earlier storms, may have washed out during subsequent rainfall-runoff events, therefore creating a source instead of a sink for pollutants (Dorman et al. 1988). Although percent increases and decreases could be calculated for above and below the sedimentation pond, once graphed versus sampling time, no trends in the data were readily identifiable. However, it has been reported that moderate to highly variable treatment should be expected from sedimentation ponds as removal is a function of detention time and runoff characteristics (Schueler et al. 1991).

To determine the performance of the sedimentation pond, an assessment of the influent and effluent water quality was made by conducting a paired t-test. The results of the paired t-test are presented in Table 5.7. 
Table 5.7. Results of the Paired t-Test Conducted Above and Below the Sedimentation Pond.

\begin{tabular}{|c|c|c|c|c|}
\hline Parameter & $\begin{array}{c}\text { Observed } \\
\text { Trend }\end{array}$ & Normality Test & $\begin{array}{c}\text { Paired t-Test } \\
\text { Statistic }\end{array}$ & $\begin{array}{c}\text { Statistical } \\
\text { Significant } \\
\text { Relationship? * }\end{array}$ \\
\hline Turbidity & $\Leftrightarrow$ & Passed & -1.39 & No \\
\hline pH & $\Leftrightarrow$ & Passed & -1.29 & No \\
\hline Conductivity & $\Leftrightarrow$ & Passed & 0.259 & No \\
\hline $\begin{array}{c}\text { Total Suspended } \\
\text { Solids }\end{array}$ & $\Leftrightarrow$ & Passed & 0.726 & No \\
\hline Alkalinity & $\Leftrightarrow$ & Passed & 1.75 & Yes \\
\hline Acidity & $\Downarrow$ & Passed & 2.10 & Yes \\
\hline $\begin{array}{c}\text { Particle Size } \\
\text { Analysis }\end{array}$ & $\Downarrow$ & Passed & 2.13 & No \\
\hline Iron & $\Leftrightarrow$ & Passed & 1.41 & No \\
\hline Sulfate & $\Leftrightarrow$ & Passed & 0.0081 & No \\
\hline Chloride & $\Leftrightarrow$ & Passed & 1.69 & No \\
\hline Calcium & $\Leftrightarrow$ & Passed & 0.187 & No \\
\hline Total Hardness & $\Leftrightarrow$ & Passed & -0.625 & No \\
\hline Magnesium & $\Leftrightarrow$ & Passed & 1.26 & No \\
\hline Manganese & $\Leftrightarrow$ & Passed & 0.933 & -0.889 \\
\hline Aluminum & $\Leftrightarrow$ & Passed & & \\
\hline
\end{tabular}

* Statistically significant relationship exists if $|\mathrm{t}|>2$.

Given the results of the paired t-test, a statistical difference between the water quality parameters at the two sites, above and below the sedimentation pond, did not exist (with the exception of acidity and particle size distribution, which barely meet the criteria of significance, “2"). Dorman et al. (1988) attributed the low, and sometimes negative efficiencies of sedimentation ponds to the fact that most pollutants associated with roadway runoff are adsorbed to smaller particles, which do not have adequate time to settle by gravity in the pond. In fact, a functioning sedimentation pond is reported to be most effective at trapping only $70 \%$ of the sediment that is carried into it during most storms (Reed 1980).

The abandoned sedimentation pond is an example another possible remediation 
method, which may be employed, along roadways and near spoils piles. In fact, a spoils pile was drained by the sedimentation basin sampled for this research (Corridor $H$ was actually constructed on top of a spoils pile, as determined from core analyses presented in Table 8.1, Appendix). The runoff water entered into the pond where it was impounded and allowed time to settle. Through this process, larger particles began to drop out of the water. In this case, the size of the basin $(20 \mathrm{ft} \times 10 \mathrm{ft}, 6.1 \mathrm{~m} \times 3.1 \mathrm{~m})$ determined the overflow velocity and thus, the size of the smallest particle to be removed. However, unlike continuous flow systems encountered in traditional water and wastewater treatment, the flow to the basin is not constant. Thus, removal of solids was expected to fluctuate similarly to the trend reported previously by Schueler et al. 1991.

The idea that sedimentation basins could be utilized to remove metal contaminants from water was originally studied as a "total" versus "dissolved" metal concentration issue (Gupta et al. 1981c), where the total concentration was much greater than the dissolved concentration, indicating that the majority of metal ions were bound to sediment particles. Kobriger and Geinopolos (1984b) found high correlations between metals, especially lead, zinc, iron, and salting particulates. Specific contaminants were found to adsorb onto a particular diameter of particle: lead and cadmium were contained by soils with distributions between 20 and 50 microns, and polycyclic aromatic hydrocarbons were absorbed by particles with sizes ranging from 6 and $60 \mu \mathrm{m}$ (Xanthopoulos and Augustin 1992). By implementing a sedimentation basin, properly sized for the expected runoff, the total suspended solids concentration would be decreased as the particles are allowed settling time, and the metal concentrations may also be attenuated by settling of smaller particles which are reportedly more likely to 
adsorb metal ions (Portele et al. 1982). Stream sediments store heavy metals and are a source for subsequent bioconcentration of metals (Van Hassel et al. 1980).

Horner et.al (1990a) reported that the best removal performance of sedimentation basin construction to mediate roadway runoff was achieved with a length:width ratio of 5:1. This was supported by findings by Reed (1980) and Nawrocki and Pietrzak (1976). Wanielista et al. (1988b) suggested that sedimentation ponds be designed to optimize groundwater inflow into the sedimentation basin.

By utilizing a system of anoxic ditchlines (ditches constructed of limestone, soda ash, or another source of alkalinity), the runoff from seeps could be channeled into the sedimentation pond. In the sedimentation pond, the particles would be allowed time for the formation and precipitation of metal hydroxides, therefore reducing the downstream dissolved metal concentration.

A functioning sedimentation pond would remove suspended solids up to a particular design particle size at a design overflow rate. The smaller particle size, the more settling time and area is required to adequately remove particles. Particle size analysis was an important parameter in this study, aiding in the determination of the performance of the sedimentation pond emptying into Laurel Run. The settling velocity of a rigid particle can be defined using Stoke's Law (under laminar flow conditions,) which is presented in Equation 5.1 (Tchobanoglous and Schroeder 1985):

$v_{s i}\left(\right.$ Stoke' $\left.^{\prime}\right)=\frac{g\left(\rho_{p}-\rho_{w}\right) d_{p i}^{2}}{18 \mu}, \operatorname{Re}<0.3$

where $\mathrm{v}_{\mathrm{si}}$ is the particle settling velocity, $\mathrm{d}_{\mathrm{pi}}$ is the diameter of the particle, $\mathrm{g}$ is gravitational constant $\left(9.8 \mathrm{~m} / \mathrm{s}^{2}\right), \mu$ is the viscosity of water $\left(8.904 * 10^{-4} \mathrm{~Pa} / \mathrm{s}\right.$ at $\left.25^{\circ} \mathrm{C}\right), \rho_{\mathrm{p}}$ is the density of the particle (typically, $1400 \mathrm{~kg} / \mathrm{m}^{3}$ ) and $\rho_{\mathrm{w}}$ is the density of water (1000 
$\mathrm{kg} / \mathrm{m}^{3}$ ), and $\mathrm{Re}$ is the Reynolds number for laminar flow of a rigid sphere. All subsequent calculations performed at standard temperature and pressure $\left(25^{\circ} \mathrm{C}, 1 \mathrm{~atm}\right.$.) The equation for the Reynolds number is presented in Equation 5.2 (Tchobanoglous and Schroeder 1985):

$\operatorname{Re}=\frac{v_{i} d_{i} \rho_{w}}{\mu}$

where $\operatorname{Re}<0.3$ for laminar flow. From this, the average settling velocity of particles for the sedimentation pond was determined based on the average particle diameter of 31.1 $\mu \mathrm{m}$ at the inlet. Utilizing Stoke's Law as presented in Equation 5.1, the settling velocity of the particle was approximately $2.35 * 10^{-4} \mathrm{~m} / \mathrm{s}\left(1.8 * 10^{-3} \mathrm{ft} / \mathrm{s}\right)$ and Re was determined to be 0.007 ; thus the assumption of laminar flow was verified. The overflow rate can be calculated by Equation 5.3 (Tchobanoglous and Schroeder 1985):

$Q=v_{\text {scritical }} * A$

where $\mathrm{Q}$ is the overflow rate and $\mathrm{v}_{\text {scritical }}$ is the critical settling velocity set to ensure a given percent removal, and $\mathrm{A}$ is the area of the basin. The critical settling velocity is the maximum velocity for which particles can settle within a sedimentation pond. For Q/A < $\mathrm{v}_{\text {scritical }}$, all particles larger than a given size will be completely removed. Utilizing the approximate sedimentation pond area, $18.6 \mathrm{~m}^{2}$, and areas ranging from $10 \mathrm{~m}^{2}$ (approximately $200 \mathrm{ft}^{2}$ ) and $25 \mathrm{~m}^{2}$, the overflow rate was calculated. The overflow rate was based on the $\mathrm{v}_{\mathrm{si}}$ calculated in Equation 5.1 and the required percent removal, as presented in Equation 5.4 (Tchobanoglous and Schroeder 1985):

$$
\% \operatorname{Re} \text { moval }=\frac{v_{s i}}{v_{\text {scritical }}}
$$


where the percent removal rate is the amount removed by the sedimentation pond, $\mathrm{v}_{\mathrm{si}}$ is the settling velocity of the average particle diameter, and $\mathrm{v}_{\text {scritical }}$ is the critical settling velocity or the settling velocity for which $100 \%$ of the particles were removed. The removal rates for the given areas and overflow rates are presented in Figure 5.29.

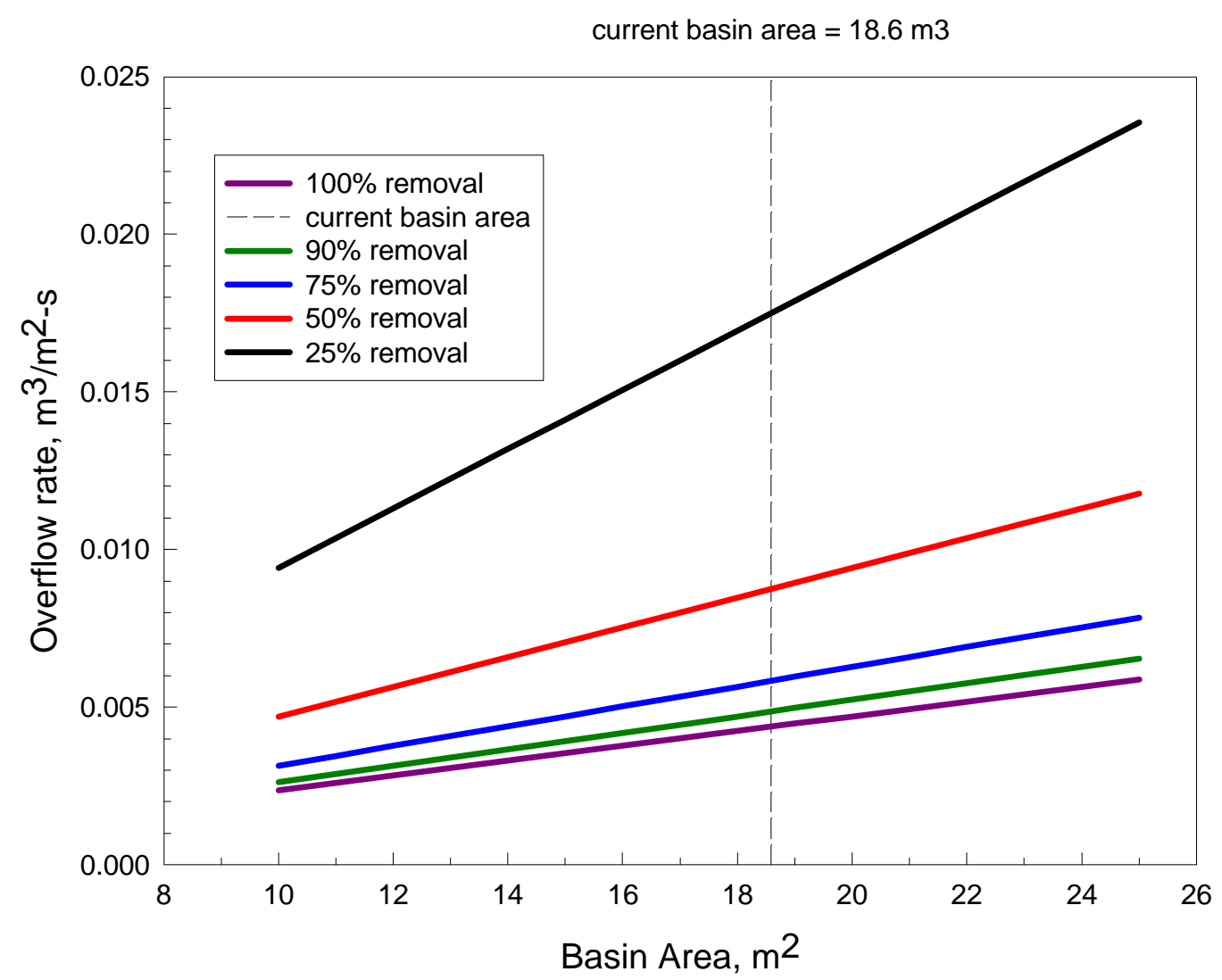

Figure 5.29. Removal Rates for Given Areas and Overflow Rates.

From Figure 5.29, the overflow rate can be determined for a specific basin area. For a removal rate of $75 \%$ (indicated by the blue line) and the area at the sedimentation pond (indicated by the vertical slashed line,) the overflow rate is approximately 0.005 $\mathrm{m}^{3} / \mathrm{m}^{2}$-s $\left(432 \mathrm{~m}^{3} / \mathrm{m}^{2}\right.$-d.) A $100 \%$ removal rate (indicated with magenta) would have an overflow rate of $0.004 \mathrm{~m}^{3} / \mathrm{m}^{2} / \mathrm{s}\left(345 \mathrm{~m}^{3} / \mathrm{m}^{2}-\mathrm{d}\right)$, based on assumption of constant flow rate 
and discrete particle size, which is $20 \%$ less than the $75 \%$ removal rate. Thus, it is reasonable for future construction operations to incorporate a more rigorous approach to basin design in order to ensure long term performance of solids removal devices. A broader understanding of rainfall-runoff relationships, settling velocities of the particles in the runoff, and particle size distributions is necessary in order to facilitate the design of sedimentation ponds to reach pollutant removal objectives (Wanielista et al. 1988b). More study is required to ascertain the particle size characteristic to runoff in West Virginia. It is recommended that in order to do so, the particle size analysis and design criteria should be based on a rigorous engineering analysis.

\subsection{BENCH DRAINAGE}

Aside from the effects of the spoils pile and the sedimentation ponds on the water quality of Laurel Run, the acidic seeps, features of historic land use activity such as abandoned mine benches may also have detrimental effects on water quality.

The water quality data collected along the bench drainage versus sampling date are presented graphically in Figures 5.30 through 5.36. 


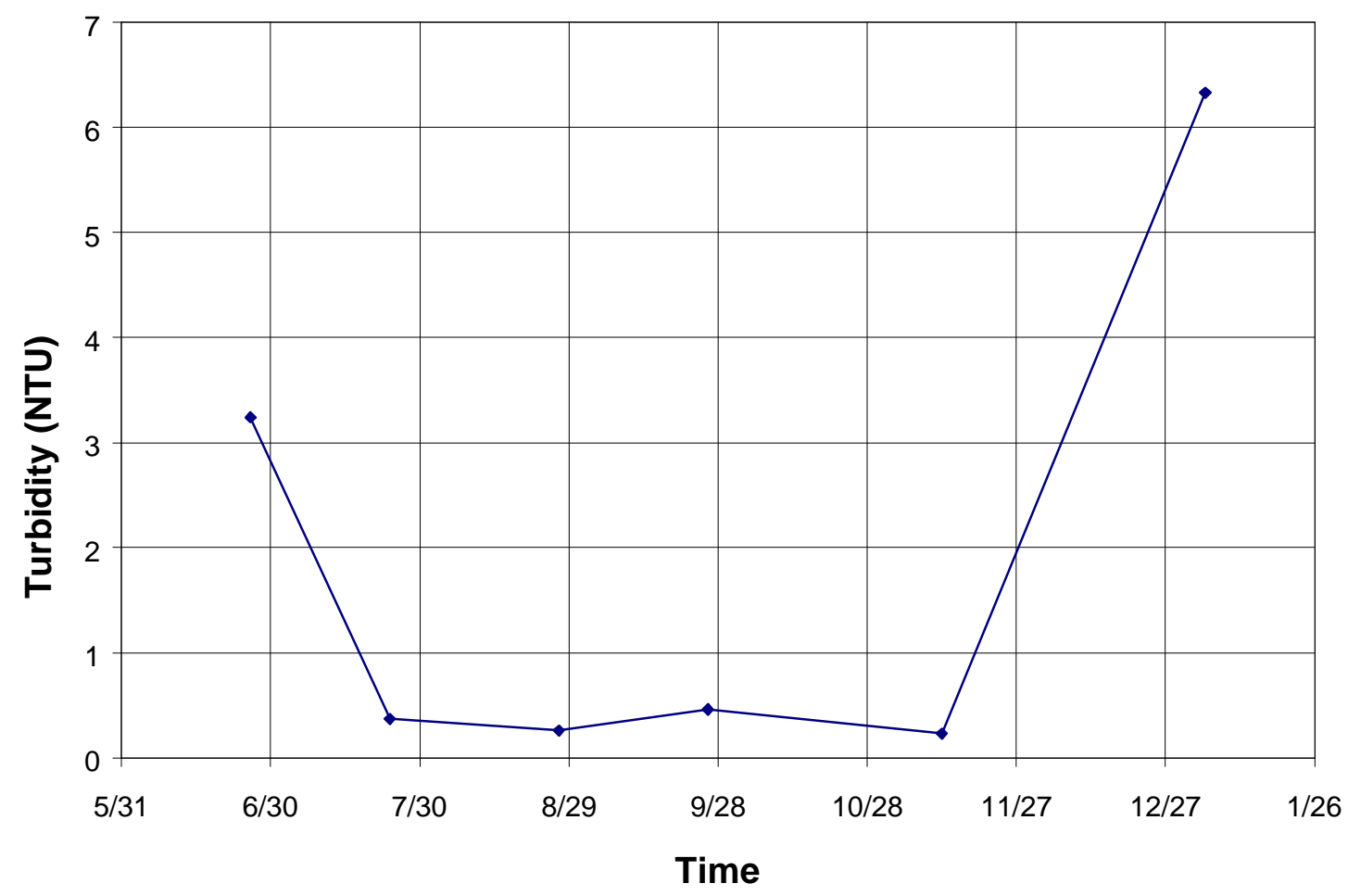

Figure 5.30. Turbidity for the Bench Drainage (Site 5).

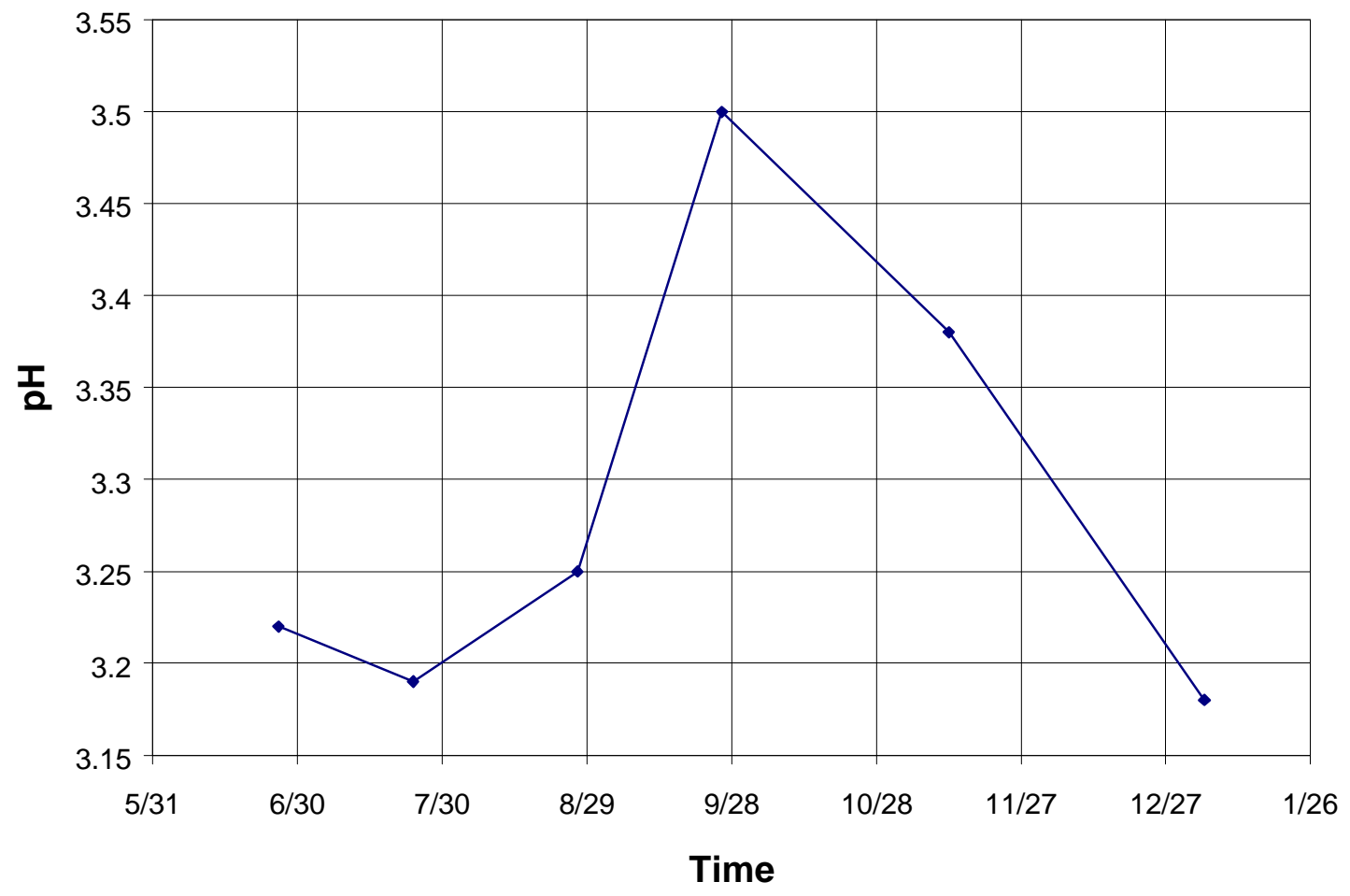

Figure 5.31. pH for the Bench Drainage (Site 5). 


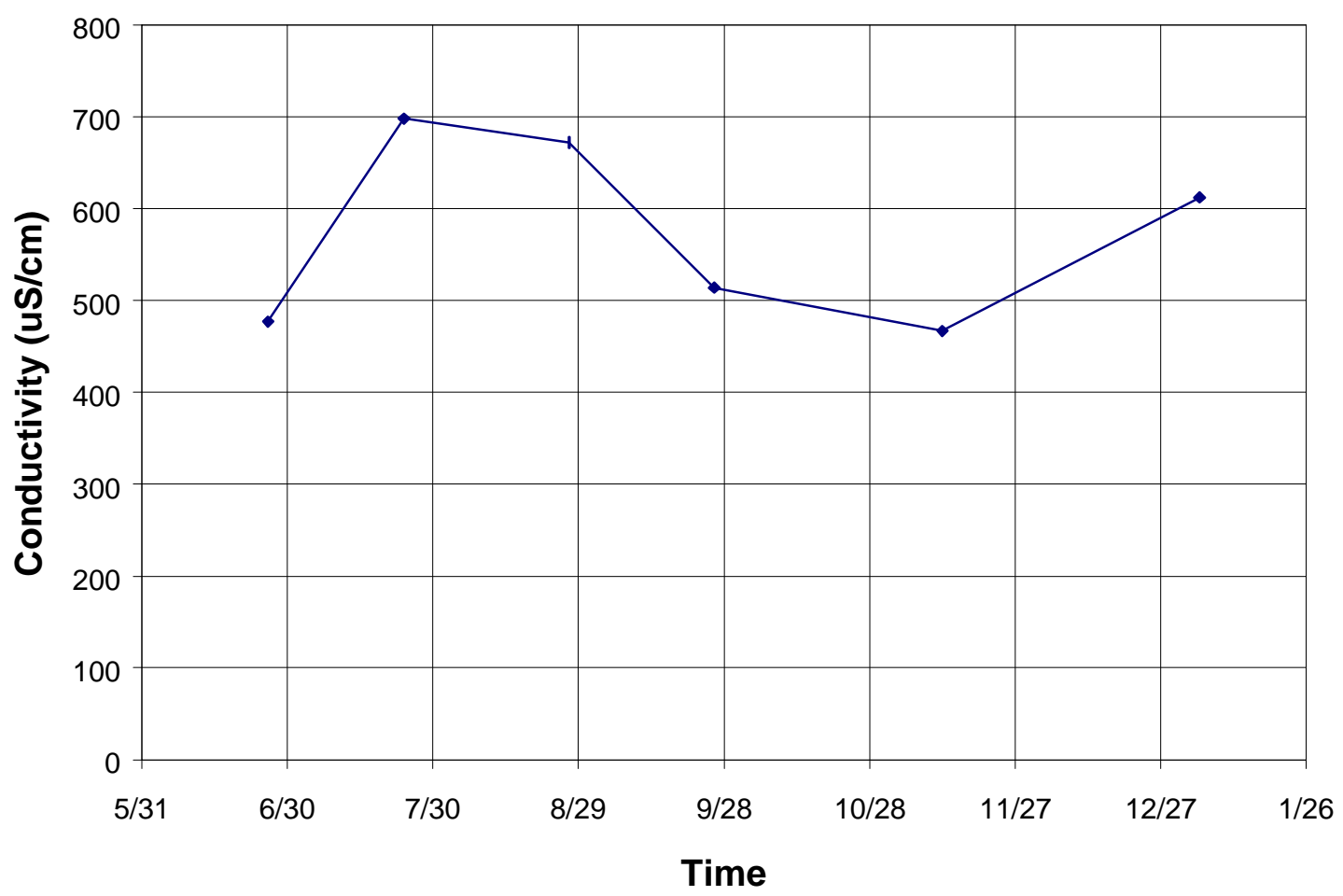

Figure 5.32. Conductivity for the Bench Drainage (Site 5).

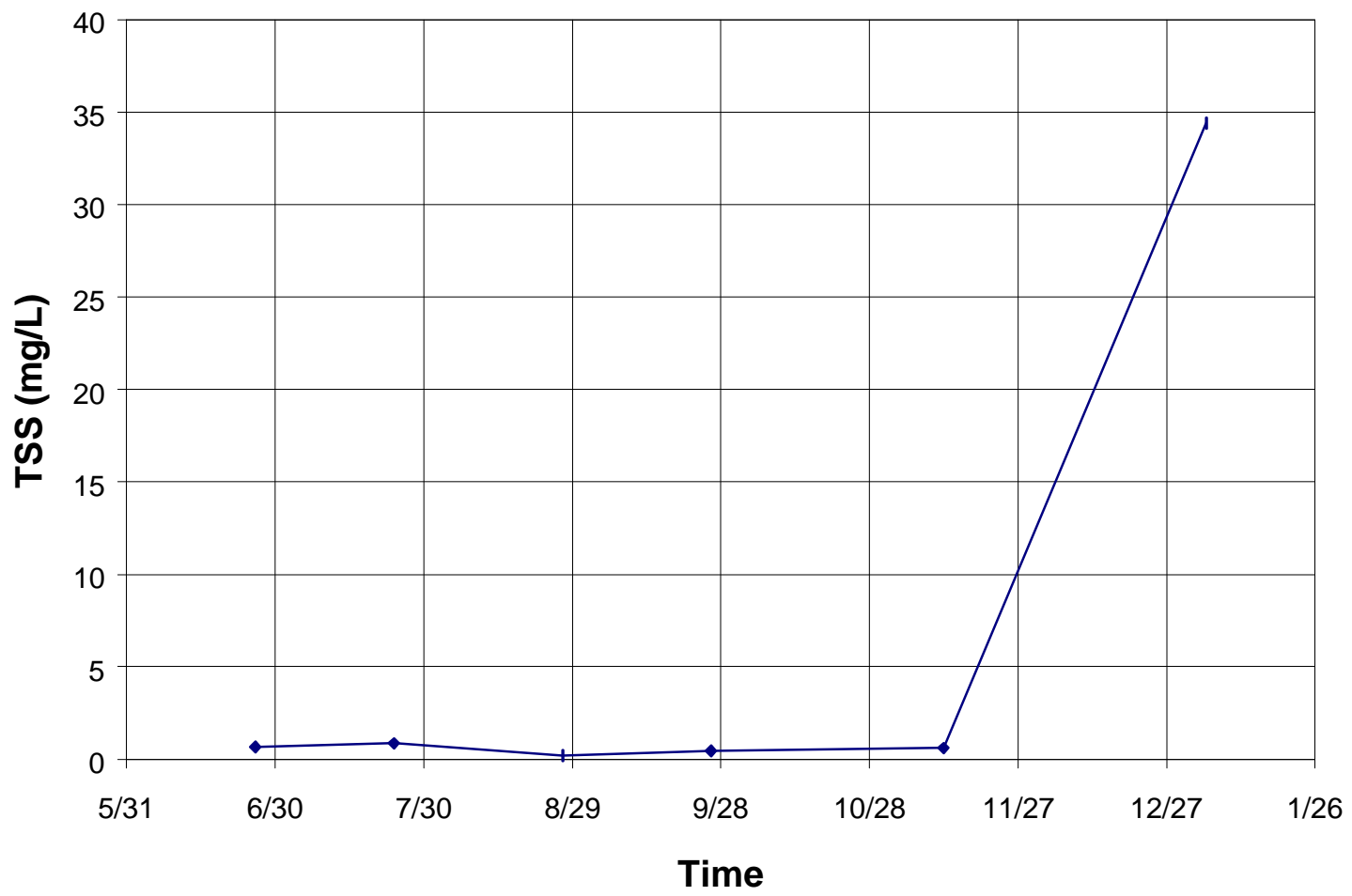

Figure 5.33. Total Suspended Solids for the Bench Drainage (Site 5). 


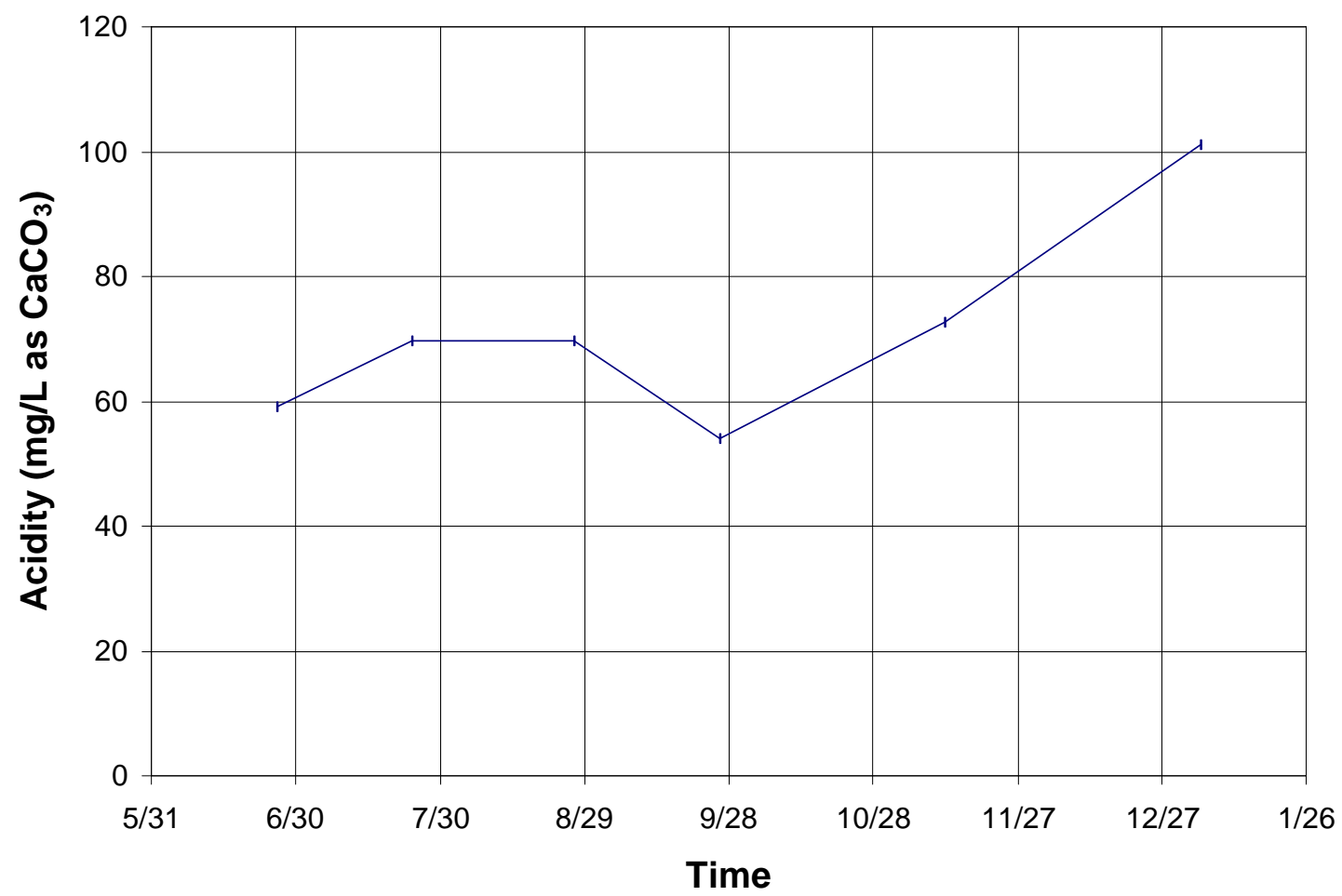

Figure 5.34. Acidity for the Bench Drainage (Site 5).

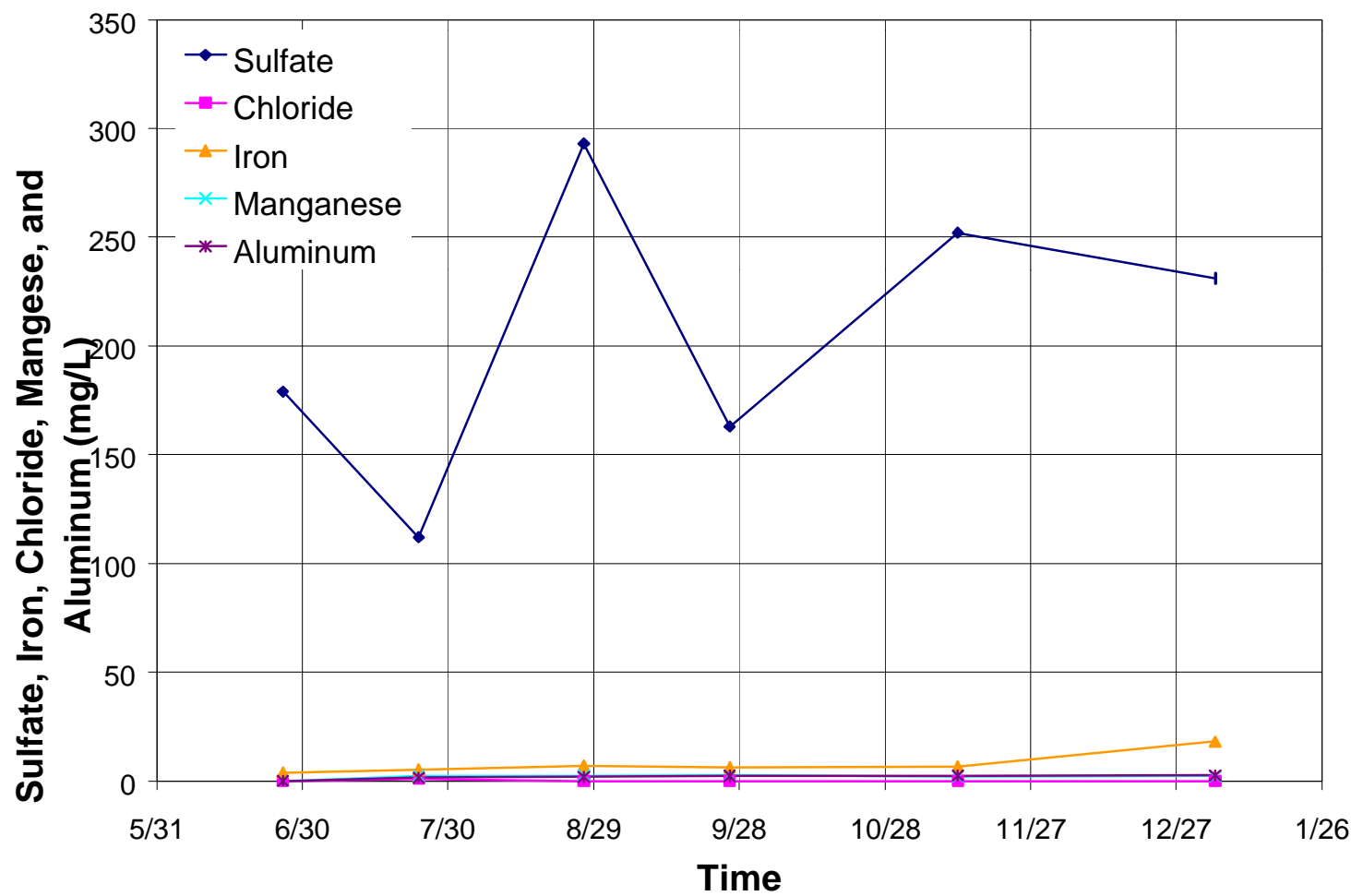

Figure 5.35. Sulfate, Iron, Chloride, Manganese, and Aluminum Concentrations for the Bench Drainage (Site 5). 


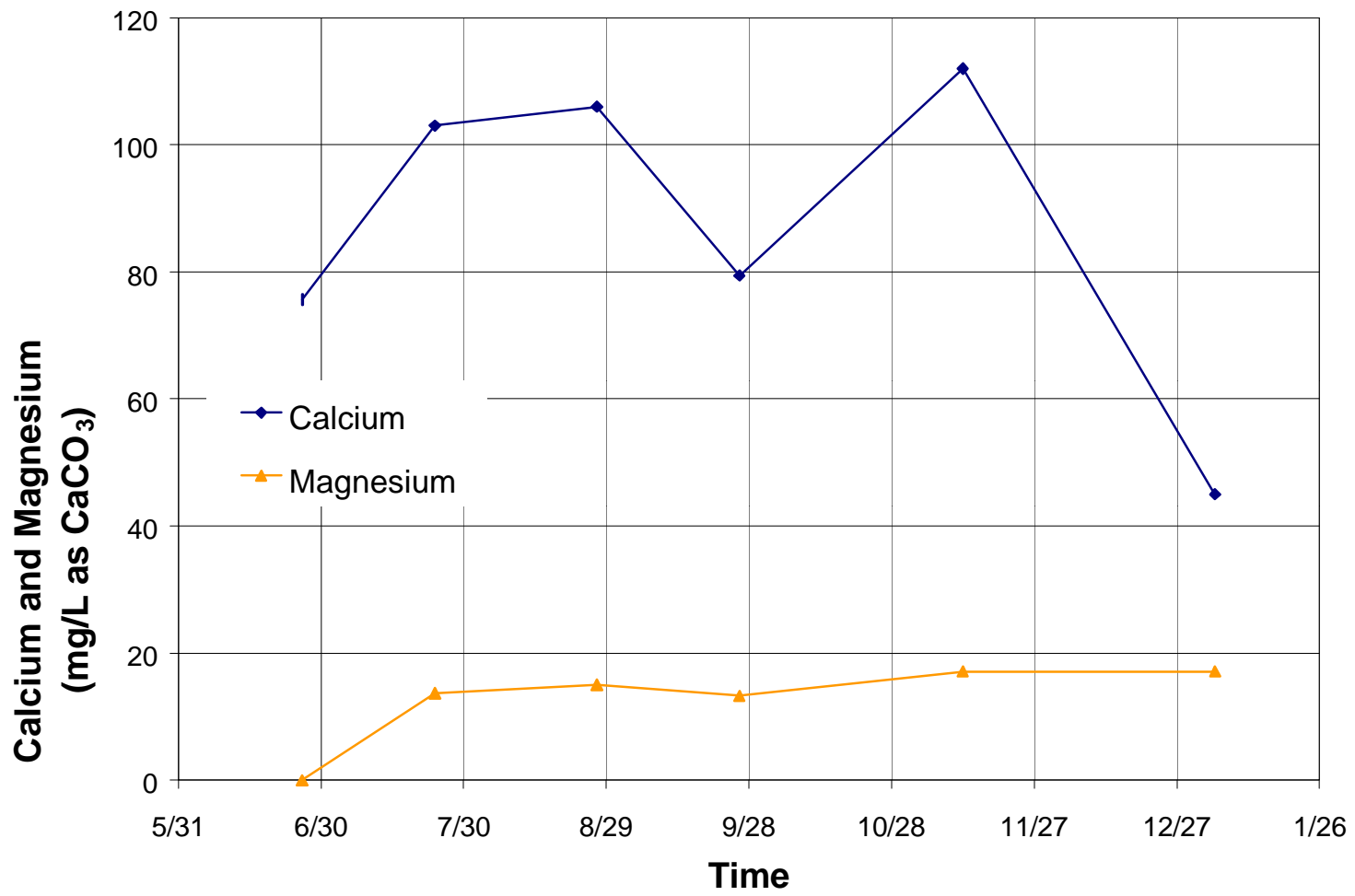

Figure 5.36. Calcium and Magnesium Concentrations for the Bench Drainage (Site 5).

Notably, there were little total suspended solids and low turbidity, with the exception of the spike in both parameters during January due to an overabundance of algae. However, these positives do not rectify the poor overall quality of water produced at the bench. Conductivity and $\mathrm{pH}$ were detrimental, failing to meet the limits (500 $\mu \mathrm{S} / \mathrm{cm}$ for conductivity and 6.5 for $\mathrm{pH}$ ) set by Jenkins et al. (1995) for a healthy stream presented previously in Table 4.1. The $\mathrm{pH}$ for the five months sampled never exceeded 3.50, WVDEP limits stated that the $\mathrm{pH}$ should be between 6.5 and 8.0. Alkalinity was not determined due to the $\mathrm{pH}$ levels which were below the methyl orange titrametric endpoint (4.3). High conductivity is indicative of other problems, such as the presence of dissolved metals. For example, the iron concentration, manganese concentration, and 
aluminum concentration were above the allowable limits specified in Table 4.1, which were $1.5 \mathrm{mg} / \mathrm{L}, 1.0 \mathrm{mg} / \mathrm{L}$, and $87 \mu \mathrm{g} / \mathrm{L}$, respectively. Sulfates were also detrimental due to the potential for sulfuric acid $\left(\mathrm{H}_{2} \mathrm{SO}_{4}\right)$ formation.

\subsubsection{Recommended Remediation}

Improved water collection and conveyance combined with treatment is recommended. The simplest method of remediation for an existing area similar to the bench drainage would be to construct an anoxic limestone ditch or a vegetated limestone channel instead of cementing the drainage ditch between the highway and the bench. Vegetative controls are the only structures which treat the runoff as it is conveyed (Burch et al. 1985a); therefore, these systems are recommended wherever possible as collection and conveyance links between treatment systems. A vegetated limestone channel or ditch line would potentially collect sediment from the runoff waters and impart alkalinity, while increasing the $\mathrm{pH}$ and facilitating the precipitation of metal hydroxides. Waller et al. (1984) recommended the utilization of unsaturated limestone to attenuate stormwater contaminants from highway runoff (i.e. lead and zinc). Armored limestone, in open ditches has been criticized its lower efficiency compared to that of unarmored limestone typical in ALDs. However, armored limestone has been reported to be $90 \%$ as effective in neutralizing $\mathrm{AMD}$ as unarmored limestone and is thus a viable media to impart alkalinity in vegetated treatment ditches (Ziemkiewicz et al. 1997).

A wetland would be suited for the treatment of drainage from the bench. The suspended solids concentration was low at Site 5, however, the metal and acidity concentrations were high. Thus, a constructed anaerobic wetland systems, as discussed 
in a preceding subsection, would be effective at reducing metal concentrations (e.g., iron, manganese, and aluminum) and acidity (Wildeman et.al 1993, Sikora et al. 1996, Eger et. al., 1994, and Faulkner and Skousen 1994). With the net alkaline additions created in an anoxic limestone ditch, the $\mathrm{pH}$ would be increased, acidity decreased, creating an alkaline discharge from the wetland. Should sediment loading become a treatment issue, the implementation of a sedimentation pond would be required. By deploying a sedimentation pond, constructed according to the general criteria presented previously in Section 5.3.2, the suspended solids concentration could be reduced as well as total metal concentrations through adsorption and sedimentation (Gupta et al. 1981c). However, the drainage and runoff from the bench can then be channeled with a similar limestone ditch to a wetland (due to the low solids and turbidity, a vegetative ditch may be effective at removing any sediment mobilized at this site.)

\subsection{LOWER LAUREL RUN}

The outlet of Laurel Run was examined to establish the collective water quality and biological productivity effects of the spoils pile, construction disturbances and contribution from roadway runoff and to depict the quality of water ultimately entering the Tygart Valley River.

The water quality data at the Lower Laurel Run sampling station are presented in Table 5.8. 
Table 5.8. Water Quality at Lower Laurel Run Sampling Station.

\begin{tabular}{|c|c|c|c|c|c|}
\hline Parameter & July & August & September & November & January \\
\hline Flow $\left(\mathrm{m}^{3} / \mathrm{s}\right)$ & 0.04 & 0.103 & 0.62 & 3.628 & $--^{1}$ \\
\hline Turbidity (NTU) & 1.27 & 3.00 & 10.1 & 0.68 & 2.85 \\
\hline pH & 7.31 & 7.28 & 7.15 & 7.09 & 6.34 \\
\hline $\begin{array}{c}\text { Conductivity } \\
(\mu \mathrm{S} / \mathrm{cm})\end{array}$ & 250 & 171 & 96.7 & 179 & 153 \\
\hline TSS (mg/L) & 2.76 & 6.15 & 17.40 & 0.48 & 1.50 \\
\hline $\begin{array}{c}\text { Alkalinity }(\mathrm{mg} / \mathrm{L} \\
\left.\text { as } \mathrm{CaCO}_{3}\right)\end{array}$ & 27.30 & 24.70 & 20.50 & 24.50 & 10.1 \\
\hline $\begin{array}{c}\text { Acidity }(\mathrm{mg} / \mathrm{L} \text { as } \\
\left.\mathrm{CaCO}_{3}\right)\end{array}$ & 3.30 & 2.12 & 1.80 & 2.19 & 0.00 \\
\hline Sulfate $(\mathrm{mg} / \mathrm{L})$ & 64.40 & 50.40 & 27.20 & 51.90 & 26.4 \\
\hline Iron $(\mathrm{mg} / \mathrm{L})$ & 0.24 & 0.15 & 0.15 & 0.19 & 1.42 \\
\hline Chloride (mg/L) & 19.70 & 11.50 & 4.57 & 15.00 & 20.2 \\
\hline $\begin{array}{c}\text { Calcium }(\mathrm{mg} / \mathrm{L} \text { as } \\
\left.\mathrm{CaCO}_{3}\right)\end{array}$ & 56.20 & 39.80 & 22.50 & 42.90 & 14.0 \\
\hline $\begin{array}{l}\text { Total Hardness } \\
\left(\mathrm{mg} / \mathrm{L} \text { as } \mathrm{CaCO}_{3}\right)\end{array}$ & 81.20 & 61.20 & 31.90 & 65.10 & 53.4 \\
\hline $\begin{array}{c}\text { Manganese } \\
(\mathrm{mg} / \mathrm{L})\end{array}$ & 0.39 & 0.29 & 0.23 & 0.34 & 0.42 \\
\hline $\begin{array}{c}\text { Aluminum } \\
(\mathrm{mg} / \mathrm{L})\end{array}$ & 0.32 & 0.27 & 0.39 & 0.12 & 0.15 \\
\hline $\begin{array}{l}\text { Magnesium } \\
\text { (mg/L) }\end{array}$ & 6.74 & 4.33 & 2.56 & 4.88 & 4.43 \\
\hline
\end{tabular}

${ }^{1}$ No flow rate was reported for this date.

The concentration versus flow for individual water quality parameters at Lower Laurel Run are presented in Figures 5.37 through 5.43. 


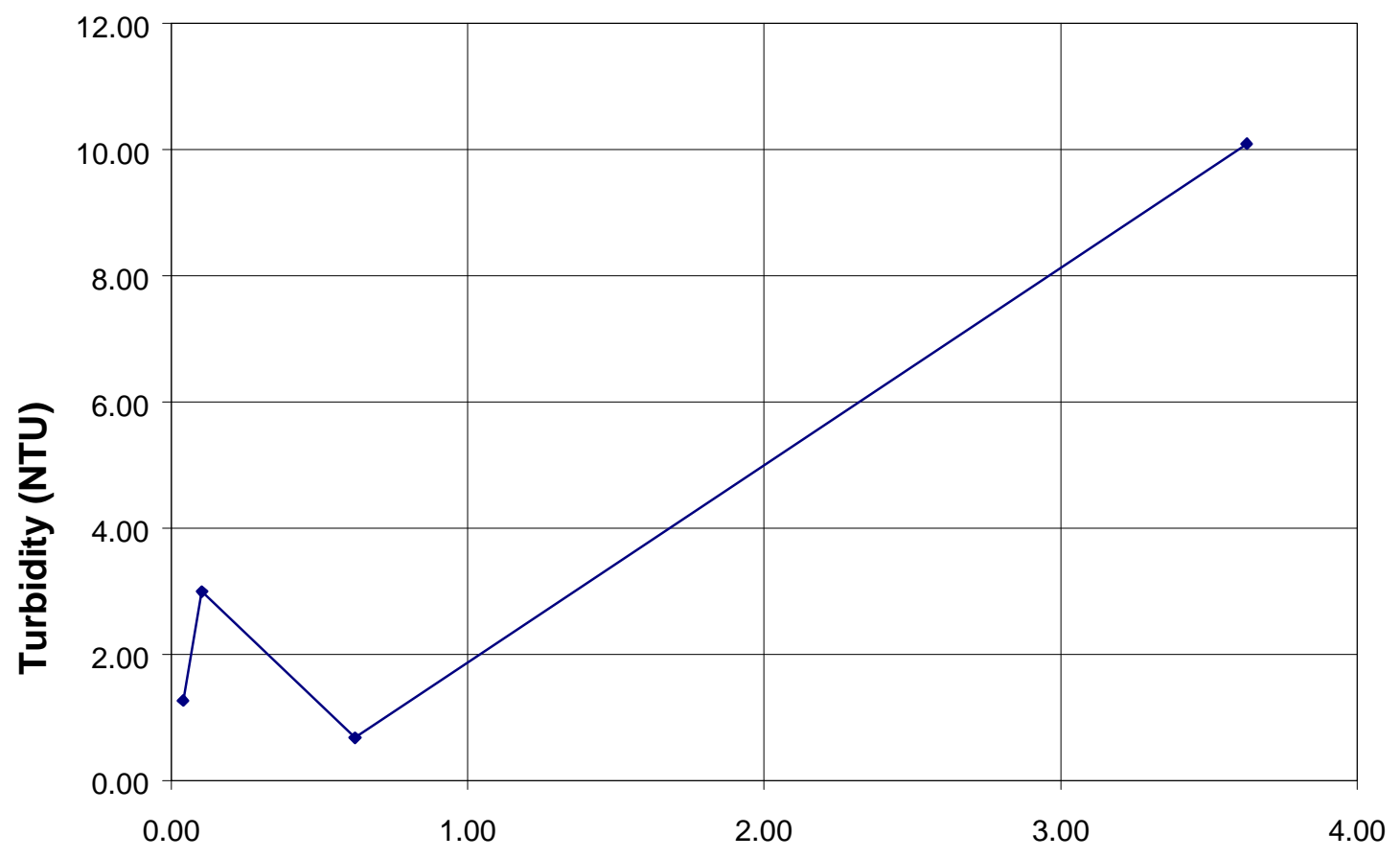

Flow Rate $\mathrm{m}^{3} / \mathrm{s}$

Figure 5.37. Turbidity Versus Flow for Lower Laurel Run (Site 1).

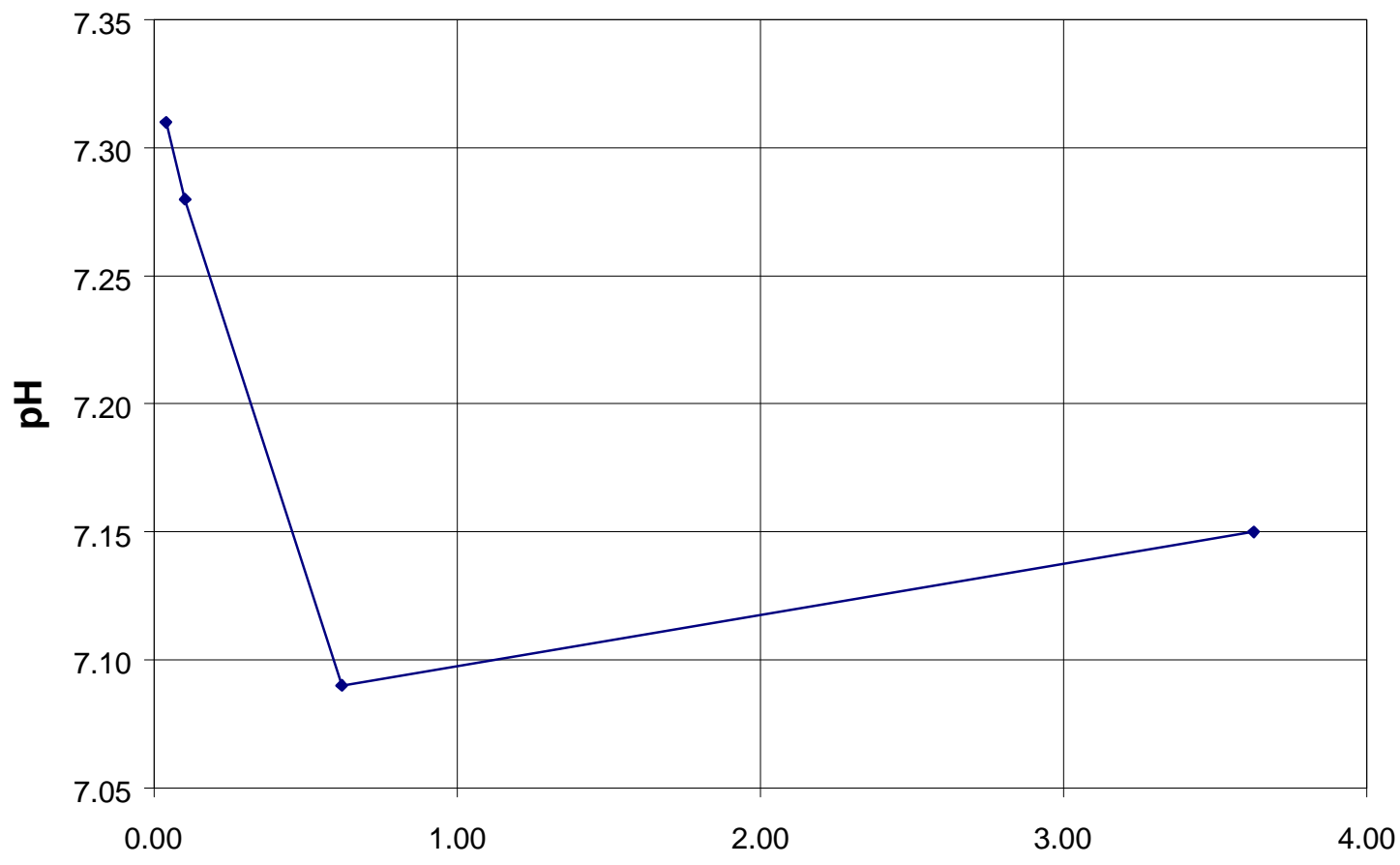

Flow Rate $\mathrm{m}^{3} / \mathrm{s}$

Figure 5.38. pH Versus Flow for the Lower Laurel Run (Site 5). 


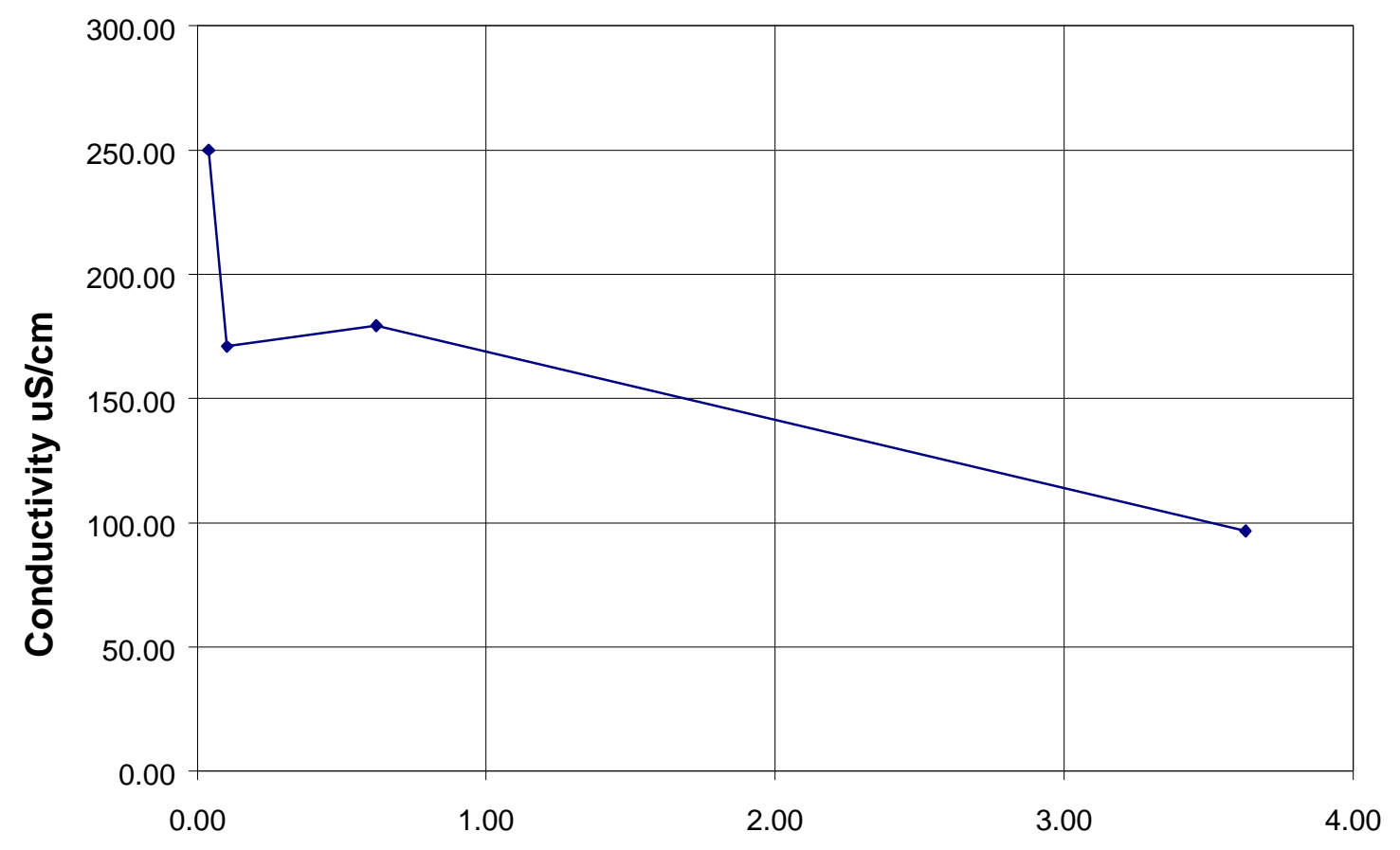

Flow Rate $\mathrm{m}^{3} / \mathrm{s}$

Figure 5.39. Conductivity Versus Flow for Lower Laurel Run (Site 1).

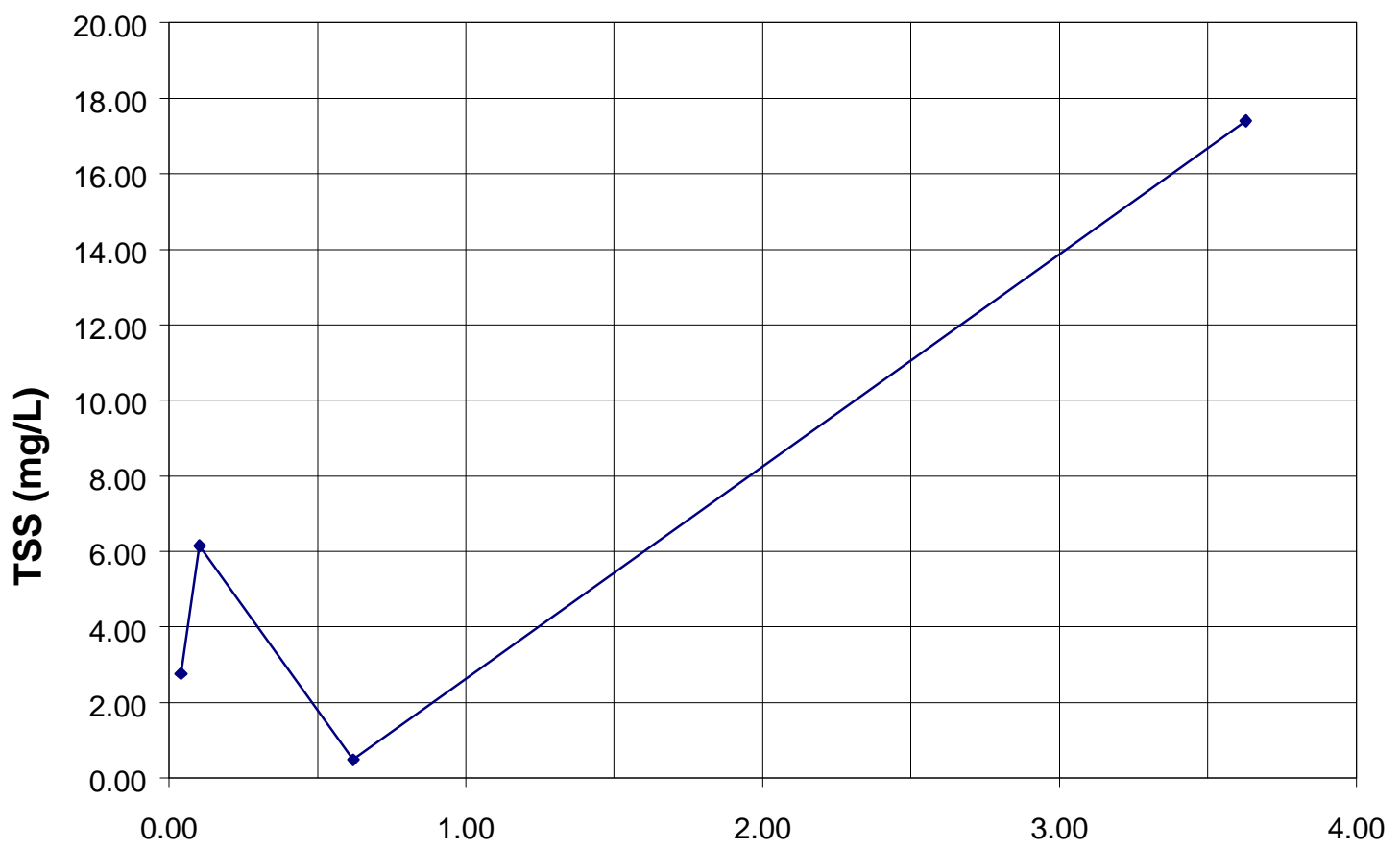

Flow Rate $\mathrm{m}^{3} / \mathrm{s}$

Figure 5.40. Total Suspended Solids Versus Flow for Lower Laurel Run (Site 1). 


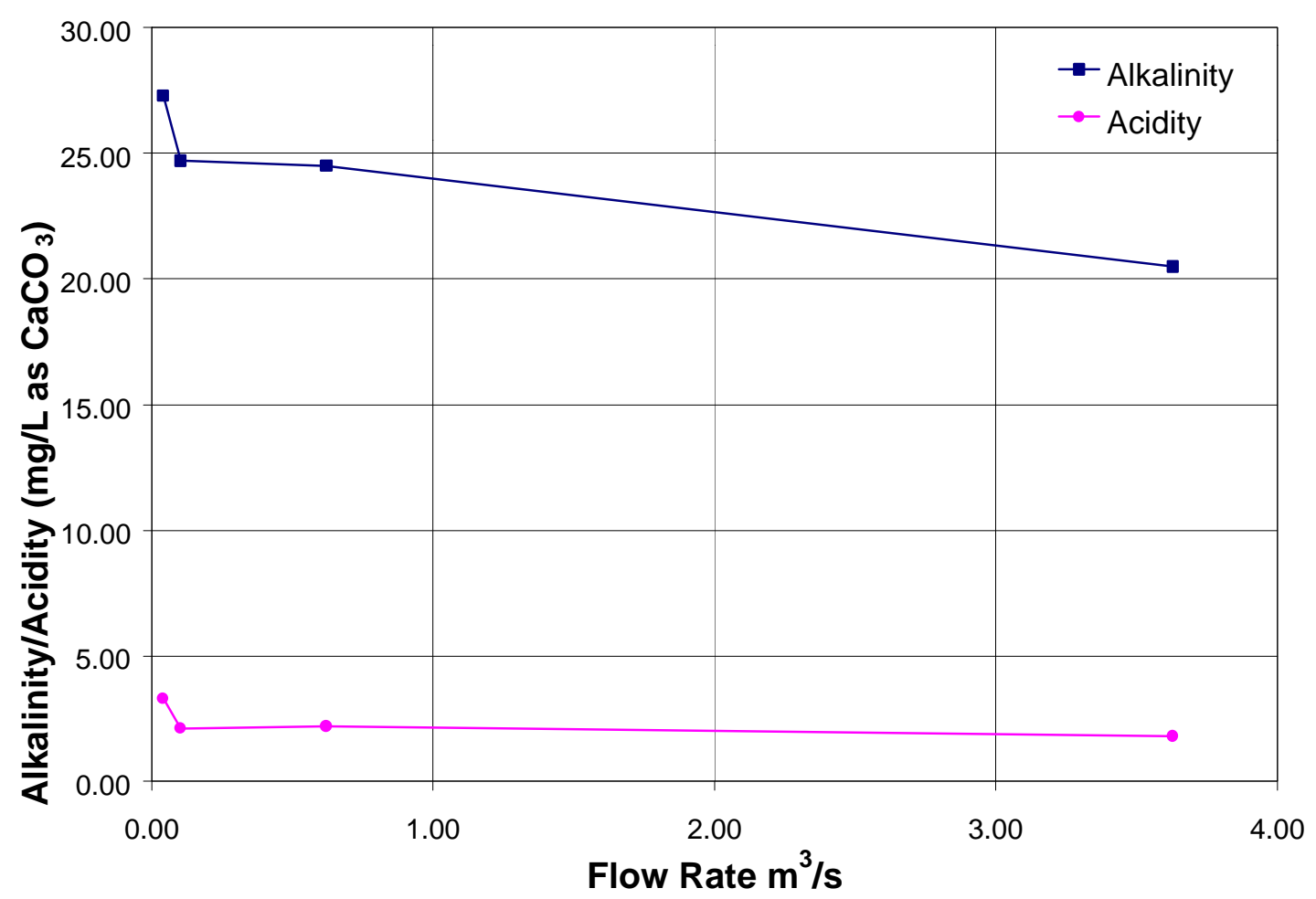

Figure 5.41. Alkalinity and Acidity Versus Flow for Lower Laurel Run (Site 1).

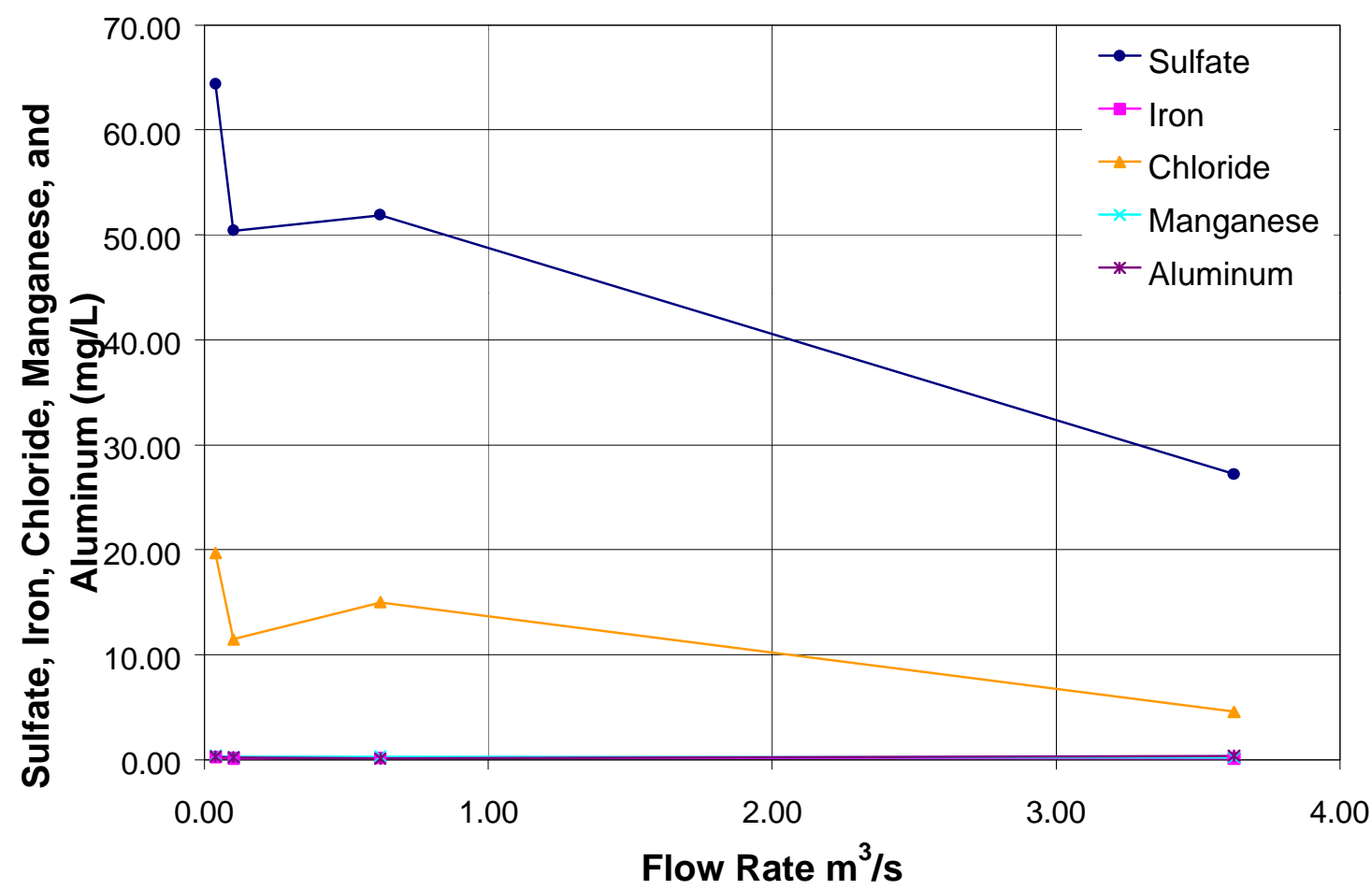

Figure 5.42. Sulfate, Iron, Chloride, Manganese, and Aluminum Concentrations Versus Flow for Lower Laurel Run (Site 1). 


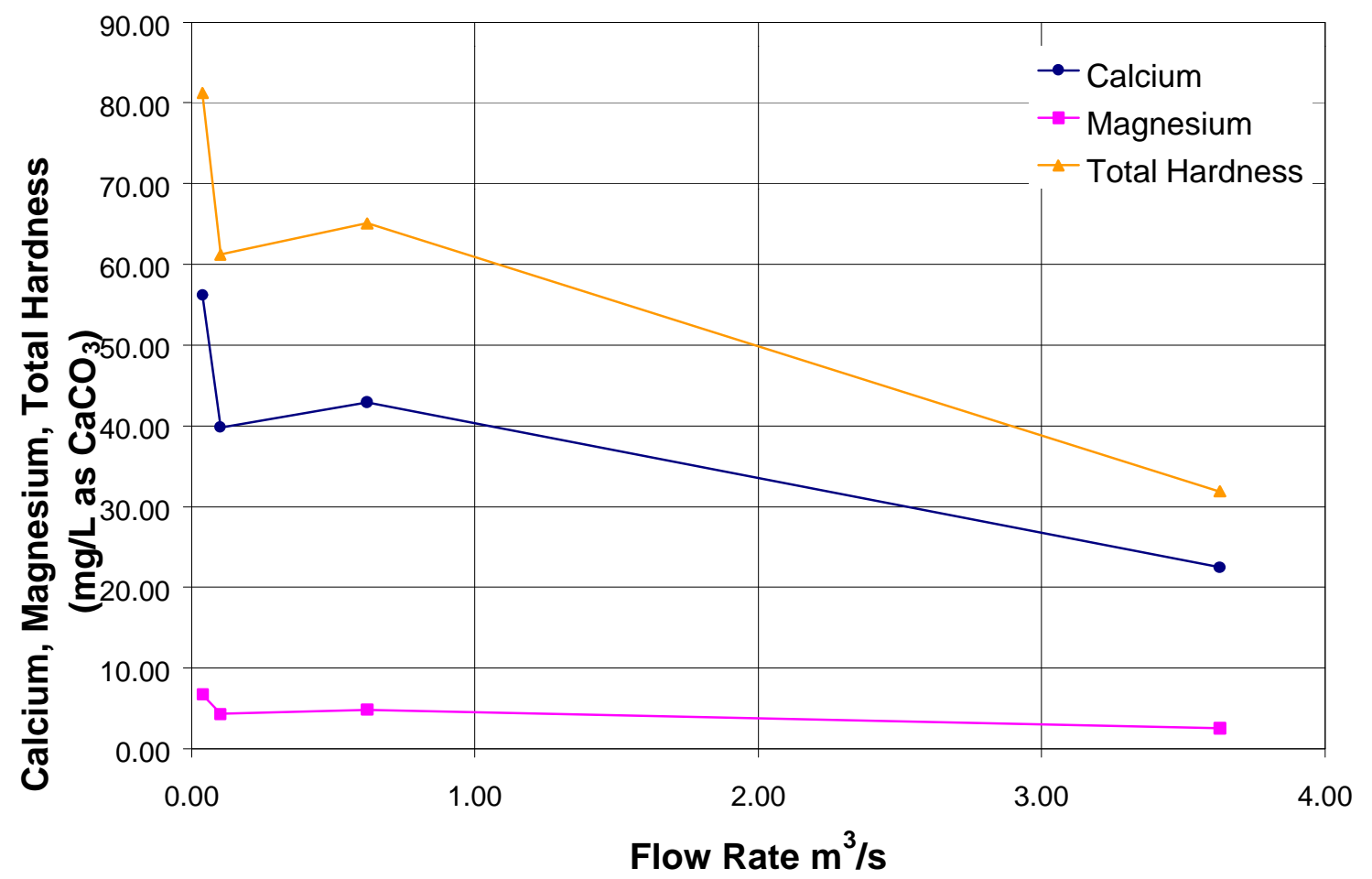

Figure 5.43. Calcium, Magnesium, and Total Hardness Versus Flow for Lower Laurel Run (Site 1).

On initial inspection, the flow rate did not appear to have an influence on turbidity, conductivity, total suspended solids, manganese, aluminum, and iron, which did not follow a distinct pattern with an increase in flow rate. Acidity remained constant with the increase in flow rate. Alkalinity, $\mathrm{pH}$, sulfate, chloride, calcium, magnesium, and total hardness appeared to decrease with an increase in flow rate.

In order to determine the influence of the flow rate on the water quality at Lower Laurel Run a one-way ANOVA was performed on water quality data. The data were first tested for normal distribution and equal variance, and then the one-way ANOVA was performed utilizing SigmaStat (SPSS 1997). The results of the one-way ANOVA for water quality as a function of flow rate at Lower Laurel Run are presented in Table 5.9. 
Table 5.9. Results of the One-Way ANOVA Conducted on Lower Laurel Run.

\begin{tabular}{|c|c|c|c|c|c|}
\hline Parameter & $\begin{array}{c}\text { Observed } \\
\text { Trends }\end{array}$ & F-Value & $\begin{array}{c}\text { Normality } \\
\text { Test }\end{array}$ & $\begin{array}{c}\text { Equal } \\
\text { Variance }\end{array}$ & $\begin{array}{c}\text { Statistically } \\
\text { Significant } \\
\text { Influenced * }\end{array}$ \\
\hline Turbidity & $\Leftrightarrow$ & 1.31 & Passed & Passed & No \\
\hline pH & $\Uparrow$ & 51.1 & Failed & Passed & Yes \\
\hline Conductivity & $\Leftrightarrow$ & 30.5 & Failed & Passed & Yes \\
\hline $\begin{array}{c}\text { Total } \\
\text { Suspended } \\
\text { Solids }\end{array}$ & $\Leftrightarrow$ & 2.12 & Passed & Passed & No \\
\hline Alkalinity & $\Downarrow$ & 199 & Passed & Passed & Yes \\
\hline Acidity & $\Leftrightarrow$ & 1.89 & Passed & Passed & No \\
\hline Sulfate & $\Downarrow$ & 36.9 & Failed & Passed & Yes \\
\hline Iron & $\Leftrightarrow$ & 1.15 & Failed & Passed & No \\
\hline Chloride & $\Downarrow$ & 12.4 & Passed & Passed & Yes \\
\hline Calcium & $\Downarrow$ & 31.6 & Failed & Passed & Yes \\
\hline Total Hardness & $\Downarrow$ & 32.5 & Failed & Passed & Yes \\
\hline Manganese & $\Leftrightarrow$ & 0.845 & Failed & Passed & No \\
\hline Aluminum & $\Leftrightarrow$ & 0.925 & Failed & Passed & No \\
\hline Magnesium & $\Downarrow$ & 8.48 & Passed & Passed & Yes \\
\hline
\end{tabular}

* If the F-value is $>1$, it was concluded that a statistically significant relationship existed between water quality parameter and flow rate.

Therefore, the flow rate had a statistically significant influence on $\mathrm{pH}$, conductivity, alkalinity, sulfate concentration, chloride concentration, calcium concentration, total hardness concentration, and magnesium concentration, which was attributed to dilution. Due to the rigor of the one-way ANOVA, non-normally distributed data are still generally acceptable for analysis (Johnson 1994, Hines and Montgomery 1980).

Lower Laurel Run had an average of 81 total individual species of benthic macro invertebrates. Sixty-five of the individuals belonged to the EPT group, which increases with improvement in water quality (average percent EPT of 42\%.) The filterer to shredder percentage was $36 \%$, which is good. The average WVSCI was 68 , which was "fair", as classified in Table 3.4, however a site can be classified as "good" with a 
minimum score of 70 . When compared with conditions of impacted upstream sites, such as Middle Laurel Run, the box culvert, and below the spoils pile, which had average WVSCI scores of 47, 63, and 59, respectively, one may conclude that there is an improvement in water quality. It is hypothesized that dilution and natural recovery mechanisms were factors in the improvement in biological index scores as water flows through Laurel Run toward the Tygart Valley River.

Correspondingly, the mean wet biomass of $0.5 \mathrm{~g}$ at Lower Laurel Run was $150 \%$ greater than that observed at the box culvert, Site 2, below the spoils pile, Site $2 \mathrm{~b}$, and Middle Laurel Run, Site 3, (0.2 g each).

Further, through electro shocking, three Lepomis cyanellus or green sunfish were collected. The Lepomis cyanellus are often found in streams which are recovering from disturbances and are tolerant to waters with metal loadings (Stauffer et al. 1995) which further supports the hypothesis that some recovery of stream health was occurring.

Based on the comparison of biological productivity and water quality data, it was determined that the quality of Laurel Run increased as water migrated along the main stem to the outlet. Further, when comparing average WVSCI scores at Site 1 with that observed at Site $2 \mathrm{a}$, the quality of waters at the Lower Laurel Run sampling station was moving toward conditions similar to those observed at the "unimpacted" site. However, HBI and WVSCI scores are determined based only on a few select species of benthic macro invertebrates. Through a comparison of average wet biomasses of $0.5 \mathrm{~g}$ and $1.6 \mathrm{~g}$ at Site 1 and Site 2a, respectively, it was concluded that while the conditions of Lower Laurel Run had improved, the biological productivity at the site remained depressed relative to the unimpacted site. A paired sampling of wet biomass and WVSCI/HBI 
score determination and water quality monitoring for comparison between Sites 1 and $2 b$ is recommended for the protracted time period to benchmark potential recovery of aquatic organisms.

It was determined from the results of the water quality assessments and biological productivity at Lower Laurel Run, that the watershed had natural methods of remediation, however, this was not sufficient to restore water quality relative to the unimpacted site, above the spoils pile. However, by utilizing the precautionary and remediation techniques, it would be possible to restore and maintain the environmental integrity of the drainage basin.

\subsection{RECOMMENDED TECHNIQUES FOR FUTURE CONSTRUCTION}

Through investigation of the construction plans of the three segments of Corridor $H$ which precede, intersect, and proceed the sites sampled along Laurel Run, examination of the water quality, benthic macro invertebrates, and fish of Laurel Run, and an intensive literature review, a series of recommendations for future construction sites has been devised. With the implementation of prevention and remediation practices, the environmental integrity of the area to be impacted by construction can be maintained. These practices include performing an acid/base account of geological materials to be disturbed, utilizing selective placement (i.e., containing the acidic material in a cap and liner system with an alkaline addition such as limestone) incorporation of passive remediation processes into roadway construction or realigning the highway.

Reed (1977) found that the primary response observed among the benthic macro invertebrates and fish communities was a reduction in both numbers of species and in 
organisms downstream from the roadway construction. Erosion control measures as are commonly applied in highway construction were of limited value in preventing damage to stream communities, especially in the early construction stages.

\subsubsection{Acid/Base Accounting}

A method commonly applied in mining operations prior to the first blast or cut is acid/base (A/B) accounting of materials to be disturbed. Core samples are bored at the mining sites prior to initial mining operations and the acid/base accounting is determined. This practice has recently gained respect with WVDOH. As part of a settlement agreement with alternatives groups, acid/base accounting will be performed on the new sections of Corridor H.

Acid/base accounting is a measure of a soil material's potential for being alkaline or acidic. The neutralization potential is the amount of buffering potential the material has and the acid producing potential is the potential to generate acidic drainage. These are fitted in a ratio (as presented previously in Chapter 2) of neutralization potential to the acid producing potential (NP/AP). An NP/AP ratio less than 1 was expected to be acid generating and an NP/AP ratio greater than 2 is expected to be nonacid producing (Ferguson and Morin 1991, Ferguson and Robertson 1994).

Once an NP/AP ratio for an area or individual site is determined, the next step is to decide whether additional prevention methods are needed. If the NP/AP ratio is above 2 , then the material can be classified as nonacid producing and construction can proceed as proposed. If the NP/AP ratio is less than 2 and greater than 1 , then additional measures need to be taken in order to assure the environmental integrity of the area will 
not be degraded, even though the NP/AP ratio is not less than one. Likewise, if the NP/AP ration is less than one, then preventive measures are required.

In the vicinity of the Laurel Run sites, cores were collected and analyzed for geological/geotechnical properties, but $\mathrm{A} / \mathrm{B}$ accounting was not performed on this segment of roadway. However, it is believed that the potential for acid production is high based on the presence of black and grey shale, as well as the predominance of the Kittanning and upper and lower Freeport coal seams. Consequently, remediation is recommended.

\subsubsection{Selective Placement}

Selective placement of waste materials is another method of prevention which can be used to minimize adverse water quality impacts in future construction, however, this would be impractical to apply to the Laurel Run sites due to insufficient land space surrounding the area and potential for further environmental impacts if spoils are disturbed. By isolating the acidic soils and rock from groundwater infiltration and receiving bodies, the impact of the spoils pile on water quality and biological populations can be greatly reduced. However, it is not feasible to apply this method on the existing spoils pile, since this would require locating a second site, excavating the material, and transporting the spoils to the second site. Such an operation could possibly inflict more damage than it would prevent. The spoils, which would be exposed during the excavation and transportation, would create a new wound to the area. A natural cap has formed over the existing pile, as the reactivity in the top layers of the spoils pile has decreased through years of leaching. This is common of spoils piles or mine tailings; initially, the metals 
concentration is moderate, then reaches a peak. When sufficient volume of water has contacted the reactive spoils material and the reactivity of the pile declines as the metal concentration within the pile are mobilized and leached out (Caruccio et al. 1988).

The key to selective placement is that the acid-producing soil and rock are placed in an area devoid of contact with water and air. Meek (1991) described selective handling and placement as a way to minimize the effects of acid producing material prior to mining or blasting. If all the overburden and waste material from construction are automatically contained properly, the need for further remediation is expected to be minimal. The containment of the spoils in a cap with a liner, or the application of a porous pad, was also recommended by Meek. PVC, covered with a layer of non-acid producing material and suitable topsoil for revegetation, was considered a favorable containment system (Caruccio and Geidel 1983, Skousen et al. 1987).

The construction plans for the three segments of Corridor $H$ examined sited the placement of spoils areas within a quarter mile off the roadway alignment (WVDOH 1993). Therefore, taking the extra step to implement a cap and liner system should not be considered an impractical requirement. By covering the cap with clean topsoil, mulch, or compost, conditions would be ideal for the germination and growth of the seedlings planted as part of revegetation efforts. Such an additional step would also provide a more in-depth protection against erosion, water infiltration, and metal leaching (Caruccio et al. 1988). As presented previously in Section 5.1.2.1, Yew and Makowski (1989) suggested a similar approach of sealing the mine spoils with a lime and topsoil cap. 


\subsubsection{Alkaline Additions}

Alkaline addition was a recommended method of acid mine/rock drainage prevention (Meek 1991, Caruccio et al. 1988, and Faulkner and Skousen 1994). Such additives included limestone admixing, phosphate admixing, and quick lime addition. The additives are typically mixed with the acid producing backfill at calculated intervals and then capped. When combined with selective placement and capping, this method not only seals off the acidic waste from oxygen and water, but also enables a second line of defense should any water infiltrate or penetrate the cap. Considering the previous method of metal contamination prevention, the addition of an alkaline substance combined with a cap and liner and selective placement measure would be an effective hybrid system used to minimize the production of acidic metal-laden leachate. The performance of an acid base account is the only way to determine the amount of alkaline material to be added. The liner would prevent percolation of groundwater into the spoils pile, potentially reducing the number of acidic seeps. The cap would inhibit rainfall and runoff waters from infiltrating into the spoils pile, also minimizing the chance of seepage. By mixing alkaline materials, such as limestone or soda ash, in with the soil, any acid-bearing water which might penetrate the cap would be treated within the system. The water would mix with the alkaline substance, the $\mathrm{pH}$ of the water would increase, metals would precipitate as metal oxides as the $\mathrm{pH}$ increased, and an adsorbent substrate for dissolved metal ion attachment would be provided (Meek 1991).

\subsubsection{Alkaline Underflow Drains}

After evaluation of the construction plans of the three segments of Corridor $H$ it 
was determined that underflow drains were implemented to collect and control the runoff along the highway. WVU-CEE researchers walked through one of these drains and noted that water dripped from the ceiling of the culvert. A drain such as this one could easily be transformed into a limestone underflow drain. By utilizing this simple addition of alkaline donating material, another line of defense against metal contamination could be activated.

Common chemical compounds and their cost for the treatment of AMD are presented in Table 5.10.

Table 5.10. Common Chemical Compounds and Cost for AMD Treatment (Skousen, et al. 1996.)

\begin{tabular}{|c|c|c|c|c|c|c|}
\hline \multirow[t]{2}{*}{$\begin{array}{l}\text { Common } \\
\text { Name }\end{array}$} & \multirow[t]{2}{*}{$\begin{array}{l}\text { Chemical } \\
\text { Name }\end{array}$} & \multirow[t]{2}{*}{ Formula } & \multirow[t]{2}{*}{$\begin{array}{c}\text { Conversion } \\
\text { Factor }^{1}\end{array}$} & \multirow[t]{2}{*}{$\begin{array}{c}\text { Neutralization } \\
\text { Efficiency }^{2}\end{array}$} & \multicolumn{2}{|c|}{$\begin{array}{l}1996 \text { Cost } \\
\$ \text { per ton or } \\
\text { gallon }^{3}\end{array}$} \\
\hline & & & & & Bulk & $<$ Bulk \\
\hline Limestone & $\begin{array}{l}\text { Calcium } \\
\text { carbonate }\end{array}$ & $\mathrm{CaCO}_{3}$ & 1 & $30 \%$ & 10 & 15 \\
\hline $\begin{array}{l}\text { Hydrated } \\
\text { Lime }\end{array}$ & $\begin{array}{c}\text { Calcium } \\
\text { Hydroxide }\end{array}$ & $\mathrm{Ca}(\mathrm{OH})_{2}$ & 0.74 & $90 \%$ & 60 & 100 \\
\hline $\begin{array}{c}\text { Pebble } \\
\text { Quicklime }\end{array}$ & $\begin{array}{l}\text { Calcium } \\
\text { oxide }\end{array}$ & $\mathrm{CaO}$ & 0.56 & $90 \%$ & 80 & 240 \\
\hline Soda Ash & $\begin{array}{l}\text { Sodium } \\
\text { carbonate }\end{array}$ & $\mathrm{Na}_{2} \mathrm{CO}_{3}$ & 1.06 & $60 \%$ & 200 & 320 \\
\hline $\begin{array}{c}\text { Caustic Soda } \\
\text { (Solid) }\end{array}$ & $\begin{array}{c}\text { Sodium } \\
\text { hydroxide }\end{array}$ & $\mathrm{NaOH}$ & 0.8 & $100 \%$ & 680 & 880 \\
\hline $\begin{array}{c}20 \% \text { Liquid } \\
\text { Caustic }\end{array}$ & $\begin{array}{c}\text { Sodium } \\
\text { hydroxide }\end{array}$ & $\mathrm{NaOH}$ & 784 & $100 \%$ & 0.46 & 0.60 \\
\hline $\begin{array}{l}50 \% \text { Liquid } \\
\text { Caustic }\end{array}$ & $\begin{array}{l}\text { Sodium } \\
\text { hydroxide }\end{array}$ & $\mathrm{NaOH}$ & 256 & $100 \%$ & 1.10 & 1.25 \\
\hline Ammonia & $\begin{array}{l}\text { Anhydrous } \\
\text { ammonia }\end{array}$ & $\mathrm{NH}_{3}$ & 0.34 & $100 \%$ & 300 & 680 \\
\hline
\end{tabular}

${ }^{1}$ The conversion factor is multiplied by the estimated tons of acidity/year to determine tons of chemical needed for neutralization per year. For liquid caustic, the conversion factor gives gallons needed for neutralization.

${ }^{2}$ Neutralization efficiency estimates the relative effectiveness of the chemical in neutralizing AMD acidity. For example, if 100 tons of acidity/year was the amount of acid to be neutralized, then it can be estimated that 82 tons of hydrated lime would be needed to neutralize the acidity in the water $(100(0.74) / 0.90)$.

${ }^{3}$ Price of chemical depends on the quantity being delivered. Bulk means delivery of chemical in a large truck, whereas <Bulk means purchased in small quantities. 
Limestone, or calcium carbonate, is the least costly and very commonly utilized chemical treatment for acidic waters. In designing to fill the culvert with limestone, or other chemical treatments, the depth of limestone should be at least 6 in $(15.2 \mathrm{~cm})$ (Faulkner and Skousen 1994). As previously mentioned, armored limestone has been reported to be $90 \%$ as effective in neutralizing AMD as unarmored limestone (Ziemkiewicz et al. 1997).

\subsubsection{Realignment of the Highway}

In the event the aforementioned preventive techniques are not suitable for implementation at a particular site, then highway realignment may be necessary. Assuming that acid/base accounting and core sampling were conducted, the overall condition of the proposed route and the surrounding area can be determined. From this information, an alternative route may be derived. If the quality of the entire area were poor, then more drastic amendments to the proposed alignment would be required. Due to the acidic nature of soil and the geochemistry common to West Virginia and the midAppalachian region, radically rerouting the highway would probably not improve the situation, as similar conditions will likely be present in most areas in the coal-producing Mid-Appalachian region. Thus, focus should be on identifying potential problems in predesign, to avoid major acid seeps and features such as mine benchs and spoils, incorporate treatment processes into design and construction, and provide routine monitoring of water quality, fish, and benthic macro invertebrates to ensure that further proactive remediation methods are employed as necessary to minimize environmental impacts. 


\subsection{CONCLUSIONS AND RECOMMENDATIONS}

During the construction of Appalachian Corridor $H$, a segment of highway between Buckhannon and Elkins, West Virginia, mine spoils and land use features related to historic mining were disturbed. An assessment of the water quality, benthic macro invertebrates, and fish populations was conducted to ascertain the condition of the water and to evaluate the biological productivity of Laurel Run, a tributary of the Tygart Valley River which runs parallel to Corridor $H$. Through the examination of the water quality and biological data, recommendations for remediation and mitigation, as well as preventive techniques for future construction were developed.

Historically, environmental impacts due to roadway construction and highway maintenance were overlooked in pre and post design assessments of alignments. Roadway construction through West Virginia and the Mid-Appalachian region should be handled in a manner more like that of mining operations, with development and employment of similar preventive techniques to maintain environmental integrity, which includes roadway engineers thinking as miners by first identifying potential acidity and metal loading sources, and second by implementing the appropriate precautionary methods.

\subsection{CONCLUSIONS}

\subsubsection{The Spoils Pile}

Based on a comparison of water quality and benthic macro invertebrate samples collected from sampling stations above and below the spoils pile, it was determined that the spoils pile was a source of water impairment (e.g., dissolved iron, manganese, 
aluminum, magnesium, sulfate, acidity, and decreased $\mathrm{pH}$ ) and had a negative impact on biological productivity. The water quality and biological impairments were attributed to the ineffective vegetation of the spoils pile which served as a source of metals and acid. It is recommended that waste pile capping with bentonite in addition to revegetation be conducted to minimize water infiltration into the spoils pile and to aid in erosion control. However, additional study is necessary to ascertain which species of vegetation are most appropriate for the unique geophysical conditions encountered on the spoils pile. Additionally, wetland remediation may be possible if water can be relocated to a suitable off site location, as sufficient area immediately adjacent to the spoils pile does not exist. The application of wetlands consisting of native species in close proximity to the highway may also serve the value-added function of minimizing the propagation of invasive plant species.

\subsubsection{The Sedimentation Ponds}

It was not possible to fully establish the function of the sedimentation pond located at Upper Laurel Run. However, through an assessment of existing conditions at the site, it is postulated that the "blown out" structure was functioning more as a wetland as opposed to an effective sediment trap.

In contrast, detailed evaluation of the conditions above and below the sedimentation pond at Middle Laurel Run was conducted. Based on a paired t-test conducted on the water quality data collected above and below the sedimentation pond at Middle Laurel Run, it was concluded that the pond was neither a source nor a sink of pollutants, neither producing or removing contaminants. Further, it was determined that 
the pond was not constructed according to general specifications (5:1 length to width ratio) presented in the literature. It is recommended that sedimentation pond specifications be developed for implementation along West Virginia highways. The development of such West Virginia-specific criteria will necessitate further study of the distribution of particles in runoff waters (and watershed waters, were applicable) in advance of construction followed by the corresponding calibration of overflow, surface area, and length to width ratios. Further, it is believed that through the development of sedimentation pond design standards based on rigorous engineering analysis, it will be possible to enhance the removal of metals, as many investigators have reported that the major fraction of metals $(\sim 74 \%)$ in water remain associated with fine particulate matter $(<20 \mu \mathrm{m})$.

\subsubsection{The Bench Drainage}

Through the assessment of water quality data collected below an abandoned mine bench, it was determined that seeps impacted by this past land use feature were a source of metals, sulfate, acidity, and low pH. Mitigation methods such as the installation of anoxic limestone drains, open limestone lined vegetated treatment ditches, and wetlands are suggested as potential mechanisms to remediate this site. Further, it may be advantageous to seal the bench to prevent further water infiltration. However, the importance of groundwater as a source of acidic seepage at this site is not known; thus, sealing the site may not prevent the formation of metal laden, low $\mathrm{pH}$ drainage. In the future, efforts should be made to identify potential acid producing features of previous

land use such as the abandoned mine bench in advance of roadway construction. The 
benefits obtained by avoiding these sources should then be weighed against the costs of treatment or roadway realignment.

\subsubsection{Overall Impacts}

An examination of water quality, benthic macro invertebrates, and fish populations was made in order to assess the overall condition of the water from Laurel Run, immediately prior to entering the Tygart Valley River and the effect of water flow rate on water quality. Flow rate was determined to have a statistically significant influence (i.e., as the flow rate increased, the concentration of the water quality constituent decreased) on the following water quality parameters: $\mathrm{pH}$, alkalinity, sulfate, chloride, calcium, and magnesium. The decreases in concentration with increase in flow rate were attributed to dilution effects.

Based on a comparison of biological index scores between sampling stations, it appeared that the overall quality of the waters at Lower Laurel Run was not substantially impaired, with an average WVSCI score of 68 compared to a score of 75 for the unimpacted site above the spoils pile. Thus, it was believed that a form of natural remediation was occurring. However, when mean biomass of the site at Lower Laurel Run was compared with that of the unimpacted site, it was evident that the full recovery was not complete. Thus, it was concluded that basing environmental assessment on biological index scores (HBI and WVSCI) alone can be misleading, as only a limited number of indicator species are used in the determination of the scores. Consequently, it is recommended that biological index scores be supplemented with an assessment of water quality data and a determination of biomass, as a means of more rigorously gauge 
the recovery of biological communities. Additionally, future monitoring of the site is suggested as a means to further benchmark any improvements in water quality and biological populations due to either natural processes or the implementation of remedial measures.

\subsection{RECOMMENDATIONS FOR FUTURE ROADWAY CONSTRUCTION}

Through the investigation of water quality at the Laurel Run sampling stations, recommendations have been developed which can be utilized to minimize the production of potentially adverse impacts of roadway construction in West Virginia and the MidAppalachia region with similar geochemical and land use patterns. As investigators have noted an inability to predict exact post construction water quality and biological impacts, it is vital to rethink the roadway design process by practically characterizing the following parameters prior to construction:

- Baseline water quality and biological populations.

- Acid/base accounting of geological materials to be disturbed and/or exposed during construction.

- Identification and location of relevant prior land use features relative to the proposed roadway alignment.

- Assessment of suitable locations for selective placement of excess cut which may be impacted by construction.

- Ascertain presence of potentially sensitive biological receptors.

Based on the evaluation of the aforementioned parameters, all reasonable efforts should be expended to align roadways in an effort to avoid adverse impacts; however, in 
many locations throughout West Virginia, it is difficult to avoid acid producing geological formations and impacts from previous mining activity. Consequently, it is necessary to design and implement remediation measures such as anoxic limestone drains and limestone lined vegetated treatment ditches, as part of the overall roadway water collection and conveyance system. Further, passive treatment processes such as sedimentation ponds and wetlands should be strategically located in advance of construction. In order to ensure the integrity of natural systems potentially impacted by roadway runoff is not endangered, long-term monitoring of water quality and biological populations is recommended at representative locations along the roadway alignment. Through comparison with baseline data collected in advance of construction, it will then be possible to identify the presence of any unintentional impacts so that appropriate interventions, as outlined in this work, can be taken. 


\subsection{REFERENCES}

Barrett, M. E., Malina, J. F., and Charbeneau, R. J. (1998a). "Evaluation of geotextiles for temporary sediment control." Water Environ. Res., 70(3), 283-290.

Barrett, M. E., Malina, J. F. Jr., Charbeneau, R. J., and Ward, G. H. (1995a). "Characterization of highway runoff in the Austin, TX Area." Center for Research in Water Res.: Tech. Report CRWR 263, University of Texas at Austin, Austin, TX.

Barrett, M. E., Walsh, P. M., Malina, J. F., and Charbeneau, R. J. (1998b). "Performance of vegetative controls for treating highway runoff." J. Environ. Engrg., 124(11), 11211128.

Barrett. M. E., Malina, J. F. Jr., Charbeneau, R. J., and G. H. Ward (1995b). "Water quality impacts of highway construction and operation." Proc., $1^{\text {st }}$ Intern. Conf. on Water Res., ASCE, San Antonio, TX, 1844-1848.

Barrett. M. E., Malina, J. F. Jr., and Charbeneau, R. J. (1995c). A review and evaluation of literature pertaining to the quantity and control of pollution from highway runoff and construction, Tech. Rep. No. CRWR 95-5, Center for Res. in Wat. Resour., Bureau of Engrg. Res., University of Texas at Austin, Austin, TX.

Brady, K. B. C., Perry, E. F., Beam, R. L., Bisko, D. C., Gardner, M. D., and Tarantino, J. M. (1994) "Evaluation of acid-base accounting to predict the quality of drainage at surface coal mines in Pennsylvania, U.S.A." Proc., 3rd Int. Conf. On the Abatement of Acidic Drainage, 1, April 24-29, 138-147.

Brooks, R. P. (1984). “Optimal Designs for Restored Wetlands.” Contribution No. 264, Depart. of Biology, Pennsylvania State University, University Park, PA, 19-29.

Burch, C.W., Johnson, F., and Maestri, B. (1985). Management Practices for Mitigation of Highway Runoff Pollution: Volume I, Guidelines, FHWA/RD-85-002, Versar Inc., Springfield, VA.

Carlstrom, S. (1981). Use of Detention Basins and Wetlands to Treat Urban Runoff, Minnesota Dept. of Transportation, Office of Environmental Services.

Caruccio, F.T., and Geidel, G. (1983). "The effect of plastic liner on acid loads/DLM site, West Virginia." Proc., $4^{\text {th }}$ West Virginia Surface Mine Task Force Sym., Clarksburg, WV.

Caruccio, F. T., Hossner, L. R., and Geidel, G. (1988). "Pyretic materials: Acid drainage, soil acidity, and liming." Reclam. of Surface-Mined Lands, 1, 159-190.

Chisholm, J.L., and Downs, S.C. (1978). Stress and Recovery of Aquatic Organisms as Related to Highway Construction along Turtle Creek, Boone County, West Virginia, USGS Water-Supply Paper 2055. 
Clesceri, L.S.; Greenberg, A.E.; and Eaton, A.D. (1998). Standard Methods for the Examination of Water and Wastewater, $20^{\text {th }}$ Edition, American Public Health Association, American Water Works Association, Water Environment Federation, Baltimore, MD.

Crebbin, C. (1988). Laboratory Evaluation of Geotextile Performance in Silt Fence Applications Using a Subsoil of Glacial Origin, University of Washington, Seattle, WA.

De Jong, J. (1976). "The Purification of Water with the Aid of Rush or Reed Beds," Biological Control of Water Pollution, J. Tourbier and R. W. Pierson, Jr., eds., University of Pennsylvania Press, PA, 133-139.

Dee, D. D. Jr., Bottomley, G., and J. Olenik (1998). "BMP considerations for a roadway project located within a water quality reservoir watershed." Proc., of $199825^{\text {th }}$ Annual Conf. on Water Res. Planning and Mngmt., ASCE, Chicago, WI, 494-499.

Dodson, R. D. (1999). Storm Water Pollution Control. Second edition, McGraw-Hill, New York, NY.

Dorman, M.E., Hartigan, J., Johnson, F., and Maestri, B. (1988). Retention, Detention and Overland Flow for Pollutant Removal from Highway Stormwater Runoff: Interim Guidelines for Management Measures, FHWA/RD-87/056, Versar Inc., Springfield, VA.

Driscoll, E.D., Shelley, P.E., and Strecker, E.W. (1990). Pollutant Loadings and Impacts from Highway Stormwater Runoff, Vol. III: Analytical Investigation and Research Report, Federal Highway Administration, Office of Research and Development Report No. FHWA-RD-88-008.

Faulkner, B., and J Skousen (1998). "Acid Mine Drainage Inventory in West Virginia," Green Lands, 28, 3.

Faulkner, B. B., and J. G. Skousen (1994). "Treatment of acid mine drainage by passive treatment systems." International Land Reclamation and Mine Drainage Conference, U.S. Bureau of Mines SP 06A-94, April 24-29, Pittsburgh, PA, 250.

Ferguson, K. D., and Morin, K. A. (1991). "The prediction of acid rock drainage lessons from the database." Proc., $2^{\text {nd }}$ Int. Conf. on the Abatement of Acidic Drainage, 83-106.

Ferguson, K. D., and Robertson, J. D. (1994). "Assessing the risk of acid rock drainage." Int. Land Reclam. and Mine Drainage Conf., 1, 2-11.

Gerber, D. W., Burris, J. E., and Stone, R. W. (1985). "Removal of dissolved iron and manganese ions by a Sphagnum moss system." Wetlands and Water Mngmt on Mined Lands, 365-372. 
Gupta, M.K., Agnew, R.W., Gruber, D., and Kreutzberger, W. (1981). Constituents of Highway Runoff Vol. IV: Characteristics of Runoff from Operating Highways, Research Report, FHWA/RD-81/045, a report prepared for the Federal Highway Administration by Envirex, Inc., Milwaukee, WI.

Guy, H. P. (1964). "An Analysis of Some Storm-Period Variables Affecting Stream Sediment Transport," US Geological Survey Professional Paper 462-E, 1-8.

Hayter, A.J. (1996). Probability and Statistics for Engineers and Scientists, PWS Publishing Co., Boston, MA.

Henrot, J., and Wieder, R. K. (1990). "Processes of iron and manganese retention in laboratory peat microcosms subjected to acid mine drainage." J. Environ. Qual., 19, 312320.

Hines, W.A., and Montgomery, D.C. (1980). Probability and Statistics in Engineering and Management Science. John Wiley \& Sons, New York, NY.

Horner, R. R. (1985). Highway Runoff Water Quality Research Implementation Manual: Volume 1, Water Quality Criteria., WA-RD 72.1, Washington State Department of Transportation, Planning Research and Public Transportation Division, Olympia, WA.

Horner, R. R., Guedry, J., and M. H. Kortenhof (1990). Improving the Cost Effectiveness of Highway Construction Site Erosion and Pollution Control: Final Report, FHA/WA-RD 200.1, Washington State Department of Transportation, Olympia, WA.

Howell, R.B., Nakao, D.I., and Gidley, J.L. (1979). Analysis of Short and Long Term Effects on Water Quality for Selected Highway Projects, NTIS PB 80-196165, California State Department of Transportation, Sacramento, CA.

Jenkins, M., Wade, E., Fletcher, J., and Hankins, J. (1995). "Economic Analysis of NonTraditional Water Resources for Aquaculture in West Virginia." Technical Report funded in part by Appalachian Regional Commission, West Virginia University, Morgantown, WV.

Johnson, R.A. (1994). Miller and Freund's Probability and Statistics for Engineers, $5^{\text {th }}$ Edition, Prentice Hall, Englewood Cliffs, NJ.

Joyce, C., and P. Ryan (1990). "Integrated environmental engineering for acid mine drainage control in Australia." Proceedings of the Western Regional Symposium on Mining and Mineral Processing Wastes, 185.

Kobriger, N., and Geinopolos, A. (1984). Sources and Migration of Highway Runoff Pollutants, Vol. III: Research Report, FHWA/RD-84/059, Federal Highway Administration, Washington, DC. 
Kuyucak, N., and P. St-Germain (1995). "Evaluation of sulfate reducing bacteria and related process parameters for developing a passive treatment method." Proceedings of the 1995 Engineering Foundation Conference on Minerals Processing II, 287.

Liao, S.-L., Field, R., and S. L. Yu (1998). "Constructed wetlands for stormwater management: Applications, design, and evaluation." Proc., of $199825^{\text {th }}$ Annual Conf. on Water Res. Planning and Mngmt., ASCE, Chicago, IL, 523-528.

Little, L. M., Horner, R. R., and B. W. Mar (1982). Assessment of Pollutant Loadings and Concentrations in Highway Stormwater Runoff, AQ-RD-39.12.1, Washington State Department of Transportation, Olympia, WA.

Lui, H., Cleveland, T. G., Wang, K. H., and D. J. Roberts (1997). "Relationship of rainfall induced erosions to shear strength and compressive strength." Proc., of $24^{\text {th }}$ Annual Water Res. Planning and Mngmt. Conf., ASCE, Houston, TX, 240-245.

Maestri, B., and B. N. Lord (1987). "Guide for mitigation of highway stormwater runoff pollution." Science of the Total Environment, 59, 467-476.

Meek, A. (1991). "Evaluation of acid prevention techniques used in surface mining." Environ. Mngmt. for the 1990's, 167-172.

Metropolitan Washington Council of Governments (1998). Performance of Current Sediment Control Measures at Maryland Construction Sites, Washington, DC.

Murawski, S. (1994). "Heavy metal removal using peat/wetland treatment." National Conference on Environmental Engineering, 408.

Nawrocki, M., and Peitrzak, J. (1976). Methods to Control Fine-grained Sediments Resulting from Construction Activity, EPA 440/9-76-026, U. S. Environmental Protection Agency.

Nawrot, J. R., Conley, P .S., and Sandusky, J. E. (1994). "Concentrated alkaline recharge pools for acid seep abatement: Principles, design, construction, and performance." Int. Land Reclam. and Mine Drainage Conf., 382-391.

Portele, G.J., Mar, B.W., Horner, R. R., and Welch, E.B. (1982). Effects of Seattle Area Highway Stormwater Runoff on Aquatic Biota, WA-RD-39.11, Washington State Department of Transportation, Olympia, WA.

Price, F., and D. Yonge (1995). "Enhancing contaminant removal in stormwater detention basins by coagulation." Transportation Research Record 1483, 105-111.

Reed, J.R., Jr. (1977). Stream Community Response to Road Construction Sediments, Virginia Water Resources Research Center, Blacksburg, VA, Bulletin 97, 61. 
Reed, L. A. (1978). Effectiveness of Sediment-Control Techniques Used During Highway Construction in Central Pennsylvania, USGS Water-Supply Paper 2054.

Reed, L.A. (1980). Suspended-Sediment Discharge in Five Streams near Harrisburg, PA, Before, During, and After Highway Construction, USGS Water-Supply Paper 2072.

Sansalone, J. J., Koran, J. M., Smithson, J. A., and S. G. Buchberger (1998). "Physical characteristics of urban roadway solids transported during rain." J. Environ. Eng., 124(5), 427-440.

Schueler, T.R., and Lugbill, J. (1990). Performance of Current Sediment Control Measure at Maryland Construction Sites, Metropolitan Washington Council of Governments.

Schueler, T. R., Kumble, P. A., and M A. Heraty (1991). A Current Assessment of Urban Best Management Practices, Techniques for Reducing Non-Point Source Pollution in the Coastal Zone, Review Draft, Anacostia Restoration Team, Depart. of Envir. Programs, Metropolitan Washington Council of Governments, Washington, D.C.

Schueler, T. R., and J. Lugbill (1990). Performance of Current Sediment Control Measure at Maryland Construction Sites, Metropolitan Washington Council of Governments.

Sengupta, M. (1993). Environmental impacts of mining: Monitoring, restoration, and control, Lewis Publishers, Boca Raton, FL.

Sikora, F. J., Behrends, L. L., Brodie, G. A., and Bulls, M. J. (1996). "Manganese and trace metal removal in successive anaerobic and aerobic wetlands." Proc., $13^{\text {th }}$ Annual Meeting Amer. Soc. for Surface Mining and Reclamation, Knoxville, TN, 560-579.

Skousen, J.G., Sencindiver, J.C., and Smith, R.M. (1987). A Review of Procedures for Surface Mining and Reclamation in Areas with Acid-Producing Materials, West Virginia Surface Mine Drainage Task Force.

Skousen, J.G. (2001). Personal Communication.

Smoot, J.L., Moore, T.D., Deatherage, J.H., and B.A. Tschantz (1992). Reducing Nonpoint Source Water Pollution by Preventing Soil Erosion and Controlling Sediment on Construction Sites, Technical Report R01-2512-39-001-92, Transportation Center., University of Tennessee, Knoxville, TN.

Sobek, A.A., Schuller, W.A., Freeman, J.R., and Smith, R.M. (1978). Field and Laboratory Methods Applicable to Overburdens and Minesoils. PEA-600/2-78-054. U.S. Environmental Protection Agency, Cincinnati, $\mathrm{OH}$. 
SPSS (1997). SigmaStat 2.0 User's Manual, ImageStream Graphics \& Presentation Filters, Chicago, IL.

Stark, L. R., Williams, F. M., Stevens, Jr., S. E., and Eddy, D. P. (1994). "Iron removal and vegetative cover at the Simco constructed wetland: An appraisal through year eight of operation." Proc., 3rd Int. Conf. On the Abatement of Acidic Drainage, 1, April 24-29, 89-98.

Tchobanoglous, G., and Schroeder, E.D. (1985). Water Quality, Vol. I, Addison-Wesley Publishing Company, Inc, Reading, MA.

Thrasher, M.H. (1983). "Highway impacts on wetlands: assessment, mitigation, and enhancement measures." Trans. Res. Rec., 948, 17-20.

USDA Natural Resources Conservation Service (1985). Guides for Erosion and Sediment Control in California, Davis, CA.

USEPA (1999). "Monitoring water quality." Volunteer stream monitoring: A methods manual, U.S. Environmental Protection Agency, Office of Water.

USEPA (1998). "Guidance for data quality assessment. Practical methods for data analysis." EPA/600/R-96/084, U.S. Environmental Protection Agency, Office of Research and Development.

Van Hassel, J.H., Ney, J.J., and Garling, D.L., Jr. (1980) "Heavy metals in a stream ecosystem at sites near highways." Transactions of the American Fisheries Society, 109(6), 636-643.

Vice, R. B., Guy, H. P., and G. E. Ferguson (1969). Sediment Movement in an Area of Suburban Highway Construction, Scott Run Basin, Fairfax County, Virginia, 1961-64, Papers 1591-E, USGS Water Supply, E1-E41.

Vile, M. A., and K. R. Wieder (1993). "Alkalinity generation by Fe (III) reduction versus sulfate reduction in wetlands constructed for acid mine drainage treatment." Water, Air, and Soil Pollution, 69(3-4), 425.

Waller, B.G., Klein, H., and Lefkoff, L.J. (1984). Attenuation of Stormwater Contaminants from Highway Runoff Within Unsaturated Limestone, Dade County, Florida, USGS Water Resources Investigations Report 84-4083.

Wanielista, M.P., Yousef, Y.A., and Boss, C. (1988). Alternatives for the Treatment of Groundwater Contaminants: A Detention Pond with Groundwater Inflow, FL-ER-40-88, Florida Department of Transportation, Tallahassee, FL.

West Virginia Department of Transportation Division of Highways (1993). Contractor's Proposal, Federal Project No. CHHD-0484 (053). 
Wigington, P. J., Jr., Randall, C. W., and T. J. Grizzard (1983). "Accumulation of selected trace metals in soils of urban runoff detention basins." Water Resour. Bull., 19(5), 709-718.

Wieder, R. K. (1988). "Determining the capacity for metal retention in man-made wetlands constructed for treatment of coal drainage." Mine Drainage and Surface Mine Reclam., 1, 375-381.

Wigington, P. J., Jr., Randall, C. W., and T. J. Grizzard (1986). "Accumulation of selected trace metals in soils of urban runoff swale drains." Water Resour. Bull., 22(1), 73-79.

Wildeman, T. R., Updegraff, D. M., Reynolds, J. S., and Bolis, J. L. (1993). "Passive Bioremediation of Metals from Water Using Reactors or Constructed Wetlands." Emerging Techn. For Bioremediation of Metals, J. L. Means and R. E. Hinchee, eds., Lewis Publishers, Boca Raton, FL.

Woodwell, G. M. (1978). "Recycling sewage through plant communities," Environmental Technology, 3(4), 10-15.

Wright, D. L., Perry, H. D., and R. E. Blaser (1976). Controlling Erosion Along Highways with Vegetation or Other Protective Cover, FHWA-VA-77-517, Fed. Highway Admin., Washington, D.C.

Xanthopoulos, C., and A. Augustin (1992). "Input and Characterization of Sediments in Urban Sewer Systems," Water Science and Technology, 25(8), 21-28.

Xanthopoulos, C., and H. H. Hahn (1990). "Pollutants attached to particles from drainage areas," Science of the Total Environment, 93, 441-448.

Yew, C.P., and Makowski, P.B. (1989). "Water quality monitoring of highway construction," Proc., 1989 National Conf. Hydraulic Engin., ASCE, New York, NY, pp. 157-162.

Yousef, Y. A., Harper, H. H., Wiseman, L. P., and J. M. Bateman (1985). Consequential Species of Heavy Metals, FL-ER-29-85, Florida Dept. of Transp., Tallahassee, FL.

Yousef, Y. A. (1986). "Nutrient transformation in retention/detention ponds receiving highway runoff." J. Water Poll. Control Fed., 58(8), 838-844.

Ziemkiewicz, P. F., Skousen, J. G., Brant, D. L., Sterner, P. L., and Lovett, R. J. (1997). "Acid mine drainage treatment with armored limestone in open limestone channels." $J$. Environ. Quality, 26(4), 1017-1024. 


\subsection{APPENDIX}

\subsection{NOMENCLATURE}

A-2-4 silty or clayey gravel and sand with 35\% (maximum) passing No. 200 sieve.

A-4 silty soil with a minimum of $36 \%$ passing No. 200 sieve.

A-6 clayey soil with a minimum of $36 \%$ passing No. 200 sieve.

$\mathrm{C}$ - argillaceous or clayey soil.

A - arenaceous or sandy soil.

L - calcareous or limey soil.

$\mathrm{MH}$ - moderately hard.

S - soft.

$\mathrm{H}$ - hard.

VH - very hard.

VS - very soft.

PL - plastic limit.

+ PL - above the plastic limit.

-PL - below the plastic limit.

NPL - non-plastic limit.

$+\mathrm{LL}-$ above the liquid limit.

M St - medium stiff.

St - stiff.

V St - very stiff.

VL - very loose.

L - loose.

MD - medium dense.

D - dense.

VD - very dense.

w - water table. 
Table 8.1. Core Samples Relating to the Sites Sampled on Laurel Run.

\begin{tabular}{|c|c|c|c|c|c|c|c|c|c|c|c|c|c|}
\hline $\begin{array}{c}\text { Core } \\
\text { Sample }\end{array}$ & $\begin{array}{l}\text { Location } \\
\text { \& Offset }\end{array}$ & $\begin{array}{r}\text { TS } \\
\text { (ft) }\end{array}$ & Layer 1 & Layer 2 & Layer 3 & Layer 4 & Layer 5 & Layer 6 & Layer 7 & Layer 8 & Layer 9 & $\begin{array}{c}\text { Layer } \\
10\end{array}$ & $\begin{array}{c}\text { Layer } \\
11\end{array}$ \\
\hline C-195 & $\begin{array}{l}412+00 ; 370 \\
\text { LT }\end{array}$ & 0.5 & A-6; stiff & $\begin{array}{l}\text { Shale; } \\
\text { clayey; } \\
\text { soft; w }\end{array}$ & $\begin{array}{l}\text { Shale; } \\
\text { moderatel } \\
\text { y hard }\end{array}$ & coal & shale & coal & $\begin{array}{l}\text { Shale; } \\
\text { MH }\end{array}$ & Coal & $\begin{array}{l}\text { Sandstone } \\
\text { hard }\end{array}$ & & \\
\hline C-196 & $\begin{array}{l}412+00 ; 240 ' \\
\text { LT }\end{array}$ & 0.6 & Top soil & Coal; w & $\begin{array}{l}\text { Shale; soft } \\
\text { to } \mathrm{MH}\end{array}$ & $\begin{array}{l}\text { Sandstone } \\
\text { hard }\end{array}$ & & & & & & & \\
\hline C-321 & $\begin{array}{l}412+00 ; 143 \\
\text { LT }\end{array}$ & 0.3 & $\begin{array}{l}\text { A-4; stiff- } \\
\text { very stiff } \\
\text { Sandstone } \\
\text { frags; } \mathbf{w}\end{array}$ & $\begin{array}{l}\text { Shale; } \\
\text { clayey, } \\
\text { soft }\end{array}$ & coal & $\begin{array}{l}\text { Shale; C S } \\
\text { to } \mathrm{MH}\end{array}$ & & & & & & & \\
\hline C-197 & $\begin{array}{l}412+00 ; 300^{\prime} \\
\text { LT }\end{array}$ & 0.3 & $\begin{array}{l}\text { A-4; w } \\
\text { medium } \\
\text { stiff; } \\
\text { sandstone } \\
\text { frags }\end{array}$ & $\begin{array}{l}\text { Shale; } \\
\text { soft; thin } \\
\text { coal } \\
\text { seams }\end{array}$ & $\begin{array}{l}\text { Siltstone; } \\
\text { soft }\end{array}$ & $\begin{array}{l}\text { Shale; } \\
\text { MH }\end{array}$ & $\begin{array}{l}\text { Shale; } \\
\text { sandy, } \\
\text { hard }\end{array}$ & $\begin{array}{l}\text { Sandstone } \\
\text { Very hard }\end{array}$ & $\begin{array}{l}\text { Sandstone } \\
\text { hard }\end{array}$ & & & & \\
\hline C-322 & $411+90$ & 0.5 & $\begin{array}{l}\text { A-4; w } \\
\text { M St }\end{array}$ & $\begin{array}{l}\text { Sandstone } \\
\text { MH }\end{array}$ & $\begin{array}{l}\text { Sandstone } \\
\text { Hard }\end{array}$ & Coal & $\begin{array}{l}\text { Shale; } \\
\text { MH }\end{array}$ & coal & $\begin{array}{l}\text { Shale; } \\
\text { MH }\end{array}$ & & & & \\
\hline C-198 & $\begin{array}{l}412+00 \\
80 \text { ' RT }\end{array}$ & 0.3 & $\begin{array}{l}\text { A-4; M St } \\
\text { Sandstone } \\
\text { frags }\end{array}$ & $\begin{array}{l}\text { Shale; soft } \\
\text { Thin coal } \\
\text { seams; } \mathbf{w}\end{array}$ & $\begin{array}{l}\text { Coal; } \\
\text { shaly }\end{array}$ & $\begin{array}{l}\text { Shale; A } \\
\text { soft }\end{array}$ & $\begin{array}{l}\text { Coal; } \\
\text { shaly }\end{array}$ & $\begin{array}{l}\text { Shale; C } \\
\text { soft, } \mathrm{MH}\end{array}$ & & & & & \\
\hline C-199 & $\begin{array}{l}415+00 \\
300 ' \mathrm{LT}\end{array}$ & 0.8 & A-4; Stiff & $\begin{array}{l}\text { Sandstone } \\
\mathrm{H} ; \mathbf{w} ; \\
\text { shale and } \\
\text { clay } \\
\text { seams }\end{array}$ & $\begin{array}{l}\text { Shale; } \\
\text { MH }\end{array}$ & & & & & & & & \\
\hline C-200 & $\begin{array}{l}415+00 \\
180 ’ \mathrm{LT}\end{array}$ & 0.8 & A-4; stiff & coal & $\begin{array}{l}\text { Shale; } \\
\text { MH, w }\end{array}$ & $\begin{array}{l}\text { Sandstone } \\
\text { hard }\end{array}$ & $\begin{array}{l}\text { Coal; } \\
\text { shaly }\end{array}$ & Shale; S & & & & & \\
\hline C-201 & $\begin{array}{l}415+00 \\
80^{\prime} \mathrm{LT}\end{array}$ & 0.4 & $\begin{array}{l}\text { A-4; V St } \\
\text { Sandstone } \\
\text { frags, } \mathbf{w}\end{array}$ & $\begin{array}{l}\text { Sandstone } \\
\text { hard }\end{array}$ & $\begin{array}{l}\text { Coal; } \\
\text { shaly }\end{array}$ & $\begin{array}{l}\text { Shale; A } \\
\text { MH }\end{array}$ & $\begin{array}{l}\text { Sandstone } \\
\mathrm{H}\end{array}$ & $\begin{array}{l}\text { Coal; } \\
\text { shaly }\end{array}$ & shale & coal & $\begin{array}{l}\text { Shale; } \\
\text { MH }\end{array}$ & $\begin{array}{l}\text { Sandstone } \\
\text { Hard }\end{array}$ & $\begin{array}{l}\text { Shale; } \\
\text { MH }\end{array}$ \\
\hline F-303 & $\begin{array}{l}416+00 \\
60 \text { ' LT }\end{array}$ & 0.3 & $\begin{array}{l}\text { A-4; Stiff } \\
\mathbf{w}\end{array}$ & $\begin{array}{l}\text { Sandstone } \\
\text { Hard }\end{array}$ & & & & & & & & & \\
\hline C-202 & $\begin{array}{l}418+00 \\
220 ' \mathrm{LT}\end{array}$ & 0.5 & $\begin{array}{l}\text { A-6; H } \\
\text { Sandstone } \\
\text { frags }\end{array}$ & $\begin{array}{l}\text { Sandstone } \\
\text { MH; coal } \\
\text { Streaks, w }\end{array}$ & $\begin{array}{l}\text { Shale; C } \\
\text { Soft }\end{array}$ & $\begin{array}{l}\text { Shale; A } \\
\text { Hard }\end{array}$ & $\begin{array}{l}\text { Sandstone } \\
\text { Hard }\end{array}$ & coal & $\begin{array}{l}\text { Shale; C } \\
\text { soft }\end{array}$ & & & & \\
\hline C-203 & $\begin{array}{l}418+00 \\
80^{\prime} \mathrm{LT}\end{array}$ & 0.5 & $\begin{array}{l}\text { A-4; St to } \\
\text { VSt; } \\
\text { sandstone } \\
\text { frags; } \mathbf{w}\end{array}$ & coal & $\begin{array}{l}\text { Shale; } \\
\text { MH }\end{array}$ & coal & $\begin{array}{l}\text { Shale; } \\
\text { MH }\end{array}$ & $\begin{array}{l}\text { Sandstone } \\
\text { Hard }\end{array}$ & coal & $\begin{array}{l}\text { Sandstone } \\
\text { hard }\end{array}$ & coal & $\begin{array}{l}\text { Shale; A } \\
\text { Hard }\end{array}$ & \\
\hline F-304 & $\begin{array}{l}419+00 \\
100^{\prime} \mathrm{RT}\end{array}$ & 0.4 & $\begin{array}{l}\text { A-4; M St } \\
\text { Sandstone } \\
\text { Frags; w }\end{array}$ & $\begin{array}{l}\text { Sandstone } \\
\text { hard }\end{array}$ & & & & & & & & & \\
\hline F-205 & $\begin{array}{l}420+99 \\
43^{\prime} \text { RT }\end{array}$ & & fill & boulder & $\begin{array}{l}\text { A-2-5; } \\
\text { VD; } \\
\text { sandstone } \\
\text { frags; w }\end{array}$ & $\begin{array}{l}\text { Sandstone } \\
\text { MH to H }\end{array}$ & & & & & & & \\
\hline
\end{tabular}




\begin{tabular}{|c|c|c|c|c|c|c|c|c|c|c|c|c|c|}
\hline $\begin{array}{c}\text { Core } \\
\text { Sample }\end{array}$ & $\begin{array}{l}\text { Location } \\
\text { \& Offset }\end{array}$ & $\begin{array}{l}\text { TS } \\
\text { (ft) }\end{array}$ & Layer 1 & Layer 2 & Layer 3 & Layer 4 & Layer 5 & Layer 6 & Layer 7 & Layer 8 & Layer 9 & $\begin{array}{c}\text { Layer } \\
10\end{array}$ & $\begin{array}{c}\text { Layer } \\
11\end{array}$ \\
\hline F-206 & $\begin{array}{l}420+96 \\
123 \text { ' RT }\end{array}$ & & $\begin{array}{l}\text { A-4; St } \\
\text { Boulders } \\
\text { and } \\
\text { Sandstone } \\
\text { frags; } \mathbf{w}\end{array}$ & $\begin{array}{l}\text { Sandstone } \\
\text { MH }\end{array}$ & & & & & & & & & \\
\hline C-204 & $\begin{array}{l}421+06 \\
167 ' \mathrm{LT}\end{array}$ & 0.5 & A-6; M St & $\begin{array}{l}\text { A-2-4; } \\
\text { MD; } \\
\text { sandstone } \\
\text { frags }\end{array}$ & $\begin{array}{l}\text { Shale; } \\
\text { soft; w }\end{array}$ & $\begin{array}{l}\text { Shale; } \\
\text { MH; thin } \\
\text { coal } \\
\text { seams }\end{array}$ & $\begin{array}{l}\text { Sandstone } \\
\text { hard }\end{array}$ & $\begin{array}{l}\text { Shale; } \\
\text { MH }\end{array}$ & $\begin{array}{l}\text { Sandstone } \\
\text { Hard }\end{array}$ & & & & \\
\hline C-208 & $\begin{array}{l}424+03 \\
62 ' \mathrm{LT}\end{array}$ & $\begin{array}{l}0.3 \\
\mathbf{w}\end{array}$ & $\begin{array}{l}\text { A-4; M St } \\
\text { Sandstone } \\
\text { frags }\end{array}$ & $\begin{array}{l}\text { Shale; } \\
\text { Soft }\end{array}$ & coal & $\begin{array}{l}\text { Shale; } \\
\text { MH }\end{array}$ & coal & $\begin{array}{l}\text { Sandstone } \\
\text { Hard }\end{array}$ & $\begin{array}{l}\text { Sandstone } \\
\text { VH }\end{array}$ & $\begin{array}{l}\text { Sandstone } \\
\text { VH }\end{array}$ & & & \\
\hline C-207 & $\begin{array}{l}424+10 \\
182 ' \text { LT }\end{array}$ & 0.4 & $\begin{array}{l}\mathrm{A}-4 ; \mathrm{M} \mathrm{St} \\
\mathbf{w}\end{array}$ & $\begin{array}{l}3 \text { layers } \\
\text { Shale; A } \\
\text { H:: C S:: } \\
\text { A MH }\end{array}$ & $\begin{array}{l}\text { Siltstone; } \\
\text { MH, clay } \\
\text { seam }\end{array}$ & $\begin{array}{l}\text { Sandstone } \\
\text { MH }\end{array}$ & $\begin{array}{l}\text { Coal; } \\
\text { boulders } \\
\text { and rock }\end{array}$ & $\begin{array}{l}2 \text { Layers } \\
\text { Shale; C } \\
\text { MH :: } \\
\text { MH }\end{array}$ & coal & $\begin{array}{l}\text { Shale; C } \\
\text { MH }\end{array}$ & coal & $\begin{array}{l}\text { Shale; } \\
\text { MH }\end{array}$ & $\begin{array}{l}\text { Sandstone } \\
\text { MH }\end{array}$ \\
\hline F-305 & $\begin{array}{l}424+00 \\
100 \text { ' RT }\end{array}$ & 0.3 & $\begin{array}{l}\text { A-4; St } \\
\text { sandstone } \\
\text { frags; } \mathbf{w}\end{array}$ & $\begin{array}{l}\text { Sandstone } \\
\text { MH }\end{array}$ & & & & & & & & & \\
\hline C-209 & $\begin{array}{l}423+00 \\
198 ' \text { RT }\end{array}$ & 0.3 & $\begin{array}{l}\text { A-2-4; } \\
\text { MD; } \\
\text { sandstone } \\
\text { frags; w }\end{array}$ & $\begin{array}{l}\text { Sandstone } \\
\text { MH }\end{array}$ & $\begin{array}{l}\text { Sandstone } \\
\mathrm{H}\end{array}$ & & & & & & & & \\
\hline C-211 & $\begin{array}{l}426+98 \\
214 ' \text { LT }\end{array}$ & 0.2 & $\begin{array}{l}\text { A-4; St; } \\
\text { sandstone } \\
\text { frags }\end{array}$ & $\begin{array}{l}2 \text { Layers } \\
\text { Shale; } \\
\text { VS:: S }\end{array}$ & $\begin{array}{l}\text { Sandstone } \\
\mathrm{H}\end{array}$ & $\begin{array}{l}5 \text { Layers } \\
\text { Shale; } \\
\text { C S:: } \\
\text { A MH; } \\
\text { w:: } \\
\text { C S:: VS:: } \\
\text { A H }\end{array}$ & $\begin{array}{l}\text { Sandstone } \\
\text { MH }\end{array}$ & $\begin{array}{l}\text { Sandstone } \\
\mathrm{H}\end{array}$ & coal & $\begin{array}{l}\text { Shale; C S } \\
\text { to } \mathrm{MH}\end{array}$ & coal & Shale; C S & $\begin{array}{l}\text { Sandstone } \\
\mathrm{H}\end{array}$ \\
\hline C-212 & $\begin{array}{l}426+98 \\
54^{\prime} \text { LT }\end{array}$ & 0.2 & $\begin{array}{l}\text { A-4; S to } \\
\text { M St; } \\
\text { large } \\
\text { sandstone } \\
\text { boulders }\end{array}$ & Shale; C S & coal & $\begin{array}{l}\text { Shale; } \\
\text { MH }\end{array}$ & $\begin{array}{l}\text { Siltstone; } \\
\mathrm{H}\end{array}$ & $\begin{array}{l}\text { Sandstone } \\
\text { VH; w }\end{array}$ & Shale; VS & $\begin{array}{l}\text { Sandstone } \\
\text { MH }\end{array}$ & $\begin{array}{l}\text { Sandstone } \\
\mathrm{H}\end{array}$ & & \\
\hline C-213 & $\begin{array}{l}426+98 \\
96 ' \text { RT }\end{array}$ & 0.2 & $\begin{array}{l}\text { A-4; S } \\
\text { Moisture } \\
\text { content } \\
\text { above PL }\end{array}$ & $\begin{array}{l}\text { Sandstone } \\
\text { MH; clay } \\
\text { layers }\end{array}$ & $\begin{array}{l}\text { Sandstone } \\
\mathrm{H}\end{array}$ & $\begin{array}{l}\text { Siltstone; } \\
\text { MH; coal } \\
\text { streaks }\end{array}$ & $\begin{array}{l}\text { Sandstone } \\
\mathrm{H}\end{array}$ & & & & & & \\
\hline C-323 & $\begin{array}{l}429+95 \\
120 \text { ' LT }\end{array}$ & 0.3 & $\begin{array}{l}\text { A-4; St; w } \\
\text { boulders }\end{array}$ & coal & Shale; S & $\begin{array}{l}\text { Shale; } \\
\text { MH }\end{array}$ & $\begin{array}{l}\text { Shale; A } \\
\text { H }\end{array}$ & $\begin{array}{l}\text { Siltstone; } \\
\text { VH }\end{array}$ & & & & & \\
\hline C-214 & $\begin{array}{l}429+95 \\
60 \text { ' LT }\end{array}$ & 0.2 & $\begin{array}{l}\mathrm{A}-4 ; \mathrm{S} \\
+\mathrm{PL}\end{array}$ & Shale; $S$ & $\begin{array}{l}\text { Shale; A } \\
\text { MH }\end{array}$ & $\begin{array}{l}\text { Sandstone } \\
\mathrm{H}\end{array}$ & $\begin{array}{l}\text { Shale; A } \\
\mathrm{H} ; \mathbf{w}\end{array}$ & $\begin{array}{l}\text { Sandstone } \\
\mathrm{H}\end{array}$ & & & & & \\
\hline
\end{tabular}




\begin{tabular}{|c|c|c|c|c|c|c|c|c|c|c|c|c|c|}
\hline $\begin{array}{c}\text { Core } \\
\text { Sample }\end{array}$ & $\begin{array}{l}\text { Location } \\
\text { \& Offset }\end{array}$ & $\begin{array}{r}\text { TS } \\
(\mathbf{f t})\end{array}$ & Layer 1 & Layer 2 & Layer 3 & Layer 4 & Layer 5 & Layer 6 & Layer 7 & Layer 8 & Layer 9 & $\begin{array}{c}\text { Layer } \\
10\end{array}$ & $\begin{array}{c}\text { Layer } \\
11\end{array}$ \\
\hline F/S-306 & $\begin{array}{l}430+20 \\
56 \text { ' RT }\end{array}$ & 0.2 & $\begin{array}{l}\text { A-4; S } \\
+\mathrm{PL} ; \\
\text { sandstone } \\
\text { frags }\end{array}$ & $\begin{array}{l}\text { A-2-4; } \\
\text { MD; } \\
\text { sandstone } \\
\text { frags }\end{array}$ & $\begin{array}{l}\text { Sandstone } \\
\mathrm{H} ; \mathbf{w}\end{array}$ & $\begin{array}{l}\text { Sandstone } \\
\mathrm{H}\end{array}$ & $\begin{array}{l}\text { Sandstone } \\
\mathrm{H}\end{array}$ & $\begin{array}{l}\text { Sandstone } \\
\mathrm{H}\end{array}$ & $\begin{array}{l}\text { Shale; } \\
\text { MH }\end{array}$ & & & & \\
\hline F/S-307 & $\begin{array}{l}430+72 \\
56{ }^{\prime} \mathrm{LT}\end{array}$ & $\begin{array}{l}0.5 ; \\
\mathbf{w}\end{array}$ & A-6; St & Shale; S & $\begin{array}{l}\text { Shale; } \\
\text { MH }\end{array}$ & $\begin{array}{l}\text { Siltstone; } \\
\mathrm{H}\end{array}$ & $\begin{array}{l}\text { Sandstone } \\
\mathrm{H}\end{array}$ & $\begin{array}{l}\text { Sandstone } \\
\mathrm{H}\end{array}$ & & & & & \\
\hline F/S-308 & $\begin{array}{l}431+46 \\
50 \text { ' RT }\end{array}$ & 0.4 & $\begin{array}{l}\text { A-4; St; } \\
\text { sandstone } \\
\text { and shale } \\
\text { frags; } \mathbf{w}\end{array}$ & $\begin{array}{l}\text { A-2-4; D; } \\
\text { sandstone } \\
\text { boulders }\end{array}$ & $\begin{array}{l}\text { Shale; } \\
\text { MH }\end{array}$ & $\begin{array}{l}\text { Shale; A } \\
\mathrm{H}\end{array}$ & & & & & & & \\
\hline F-217 & $\begin{array}{l}432+27 \\
227 \text { RT }\end{array}$ & 0.5 & $\begin{array}{l}\text { A-4; St to } \\
\text { V St; } \\
\text { +PL; } \\
\text { sandstone } \\
\text { boulders; } \\
\text { w }\end{array}$ & $\begin{array}{l}\text { Shale; A } \\
\text { MH }\end{array}$ & & & & & & & & & \\
\hline F/S-309 & $\begin{array}{l}432+35 \\
50 \text { ' LT }\end{array}$ & 0.9 & $\begin{array}{l}\text { A-2-4; } \\
\text { VD; } \\
\text { sandstone } \\
\text { frags }\end{array}$ & $\begin{array}{l}\text { Sandstone } \\
\mathrm{H}\end{array}$ & $\begin{array}{l}\text { Shale; } \\
\text { MH; w }\end{array}$ & $\begin{array}{l}\text { Shale; A } \\
\mathrm{H}\end{array}$ & $\begin{array}{l}\text { Siltstone; } \\
\mathrm{H}\end{array}$ & & & & & & \\
\hline C-218 & $\begin{array}{l}432+45 \\
321 \text { ' RT }\end{array}$ & 0.4 & $\begin{array}{l}\text { A-2-4; D; } \\
\mathbf{w}\end{array}$ & $\begin{array}{l}\text { A-2-4; D; } \\
\text { sandstone } \\
\text { boulders }\end{array}$ & $\begin{array}{l}\text { Shale; A } \\
\mathrm{H}\end{array}$ & & & & & & & & \\
\hline F/S-310 & $\begin{array}{l}432+72 \\
50 \text { ' RT }\end{array}$ & 0.2 & $\begin{array}{l}\text { A-6; V St } \\
\text { to H; } \\
\text { sandstone } \\
\text { boulders }\end{array}$ & $\begin{array}{l}\text { A-6; V St } \\
\text { to } \mathrm{H}\end{array}$ & $\begin{array}{l}\text { A-2-4; D; } \\
\text { w }\end{array}$ & $\begin{array}{l}\text { Shale; A } \\
\text { MH }\end{array}$ & $\begin{array}{l}\text { Shale; } \\
\text { MH }\end{array}$ & & & & & & \\
\hline F/S-311 & $\begin{array}{l}433+98 \\
50 \text { ' LT }\end{array}$ & & $\begin{array}{l}\text { A-4; S to } \\
\text { MSt; } \\
\text { (NPL); w }\end{array}$ & A-2-4; L & $\begin{array}{l}\text { Sandstone } \\
\text { MH }\end{array}$ & $\begin{array}{l}\text { Sandstone } \\
\mathrm{H}\end{array}$ & & & & & & & \\
\hline F-220 & $\begin{array}{l}432+12 \\
178 \text { ' RT }\end{array}$ & & $\begin{array}{l}\text { Fill (i.e. } \\
\text { Sandstone } \\
\text { boulders, } \\
\text { clay, } \\
\text { wood, } \\
\text { etc.), w }\end{array}$ & $\begin{array}{l}\text { A-4; MSt; } \\
+ \text { PL; } \\
\text { sandstone } \\
\text { boulders }\end{array}$ & $\begin{array}{l}\text { Sandstone } \\
\text { S }\end{array}$ & $\begin{array}{l}\text { Sandstone } \\
\mathrm{H}\end{array}$ & & & & & & & \\
\hline $\mathrm{C}-221$ & $\begin{array}{l}434+15 \\
320 \text { ' RT }\end{array}$ & 0.5 & $\begin{array}{l}\text { A-2-4; D; } \\
\text { sandstone } \\
\text { boulders, } \\
\text { w }\end{array}$ & $\begin{array}{l}\text { Sandstone } \\
\text { H; shaly }\end{array}$ & & & & & & & & & \\
\hline F-222 & $\begin{array}{l}434+82 \\
275, \text { LT }\end{array}$ & 0.4 & A-4; S & $\begin{array}{l}\text { A-4; NPL; } \\
\mathbf{w}\end{array}$ & $\begin{array}{l}\text { A-2-4; } \\
\text { MD; } \\
\text { sandstone } \\
\text { frags }\end{array}$ & $\begin{array}{l}\text { Sandstone } \\
\text { H; shaly }\end{array}$ & & & & & & & \\
\hline
\end{tabular}




\begin{tabular}{|c|c|c|c|c|c|c|c|c|c|c|c|c|c|}
\hline $\begin{array}{c}\text { Core } \\
\text { Sample }\end{array}$ & $\begin{array}{l}\text { Location } \\
\text { \& Offset }\end{array}$ & $\begin{array}{r}\text { TS } \\
(\mathbf{f t})\end{array}$ & Layer 1 & Layer 2 & Layer 3 & Layer 4 & Layer 5 & Layer 6 & Layer 7 & Layer 8 & Layer 9 & $\begin{array}{c}\text { Layer } \\
10\end{array}$ & $\begin{array}{c}\text { Layer } \\
11\end{array}$ \\
\hline F/P-224 & $\begin{array}{l}435+56 \\
267 \text { 'RT }\end{array}$ & 0.3 & $\begin{array}{l}\text { A-2-4; D } \\
\text { to VD; } \\
\text { sandstone } \\
\text { boulders; } \\
\text { w }\end{array}$ & $\begin{array}{l}\text { Sandstone } \\
\mathrm{H}\end{array}$ & & & & & & & & & \\
\hline F/S-312 & $\begin{array}{l}435+45 \\
235, \text { RT }\end{array}$ & 0.5 & $\begin{array}{l}\text { A-2-4; } \\
\text { MD to D; } \\
\text { sandstone } \\
\text { boulders; } \\
\text { w }\end{array}$ & $\begin{array}{l}\text { Sandstone } \\
\text { boulders }\end{array}$ & Shale; S & $\begin{array}{l}\text { Sandstone } \\
\text { H; coal } \\
\text { streaks }\end{array}$ & & & & & & & \\
\hline F/P-225 & $\begin{array}{l}436+45 \\
235 ' \mathrm{RT}\end{array}$ & 0.1 & $\begin{array}{l}\text { A-2-4; } \\
\text { VD; } \\
\text { sandstone } \\
\text { boulders; } \\
\text { w }\end{array}$ & $\begin{array}{l}\text { Sandstone } \\
\mathrm{H}\end{array}$ & & & & & & & & & \\
\hline F-260 & $\begin{array}{l}467+00 \\
\mathrm{CL}\end{array}$ & & $\begin{array}{l}\text { Spoil - } \\
\text { shale, } \\
\text { coal, silty } \\
\text { clay, etc.; } \\
\text { MD; w }\end{array}$ & $\begin{array}{l}\mathrm{A}-4 ; \mathrm{H} ; \\
\text { sandstone } \\
\text { fragments }\end{array}$ & $\begin{array}{l}\text { Siltstone, } \\
\text { MH }\end{array}$ & & & & & & & & \\
\hline C-261 & $\begin{array}{l}467+00 \\
70 \text { ' RT }\end{array}$ & & $\begin{array}{l}\text { Spoil - } \\
\text { shale, } \\
\text { sandstone, } \\
\text { clay, coal, } \\
\text { etc.; MD } \\
\text { w }\end{array}$ & $\begin{array}{l}\text { A-6; S to } \\
\text { St }\end{array}$ & $\begin{array}{l}\text { Shale; C } \\
\text { VS }\end{array}$ & $\begin{array}{l}\text { Shale; } \\
\text { MH }\end{array}$ & $\begin{array}{l}\text { Shale; A } \\
\text { MH }\end{array}$ & & & & & & \\
\hline F-259 & $\begin{array}{l}467+00 \\
110 \text { ' LT }\end{array}$ & 0.5 & $\begin{array}{l}\text { A-4; S; } \\
\text { NPL; w }\end{array}$ & $\begin{array}{l}\text { Sandstone } \\
\mathrm{H}\end{array}$ & & & & & & & & & \\
\hline C-262 & $\begin{array}{l}467+00 \\
180 ' \mathrm{RT}\end{array}$ & & $\begin{array}{l}\text { Spoil - } \\
\text { Shale and } \\
\text { sandstone } \\
\text { fragments, } \\
\text { clay, coal, } \\
\text { etc.; VL } \\
\text { to D; } \mathbf{w}\end{array}$ & $\begin{array}{l}\text { Shale; } \\
\text { MH }\end{array}$ & $\begin{array}{l}\text { Shale; C S } \\
\text { to } \mathrm{MH}\end{array}$ & $\begin{array}{l}\text { Shale; } \\
\text { MH }\end{array}$ & & & & & & & \\
\hline F-263 & $\begin{array}{l}470+50 \\
140 ' \mathrm{LT}\end{array}$ & 0.4 & $\begin{array}{l}\text { A-4; S; } \\
\text { NPL; } \\
\text { sandstone } \\
\text { fragments }\end{array}$ & $\begin{array}{l}\text { Sandstone } \\
\text { VS }\end{array}$ & $\begin{array}{l}\text { Sandstone } \\
; \mathrm{H} ; \mathbf{w}\end{array}$ & & & & & & & & \\
\hline F-264 & $\begin{array}{l}470+50 \\
60 ’ \mathrm{LT}\end{array}$ & 0.3 & A-4; St & $\begin{array}{l}\text { Sandstone } \\
\text { VS }\end{array}$ & $\begin{array}{l}\text { Sandstone } \\
\text { MH }\end{array}$ & & & & & & & & \\
\hline F-266 & $\begin{array}{l}473+50 \\
60 \text { ' LT }\end{array}$ & $\begin{array}{l}0.3 \\
\mathbf{w}\end{array}$ & A-4; St & $\begin{array}{l}\text { Sandstone } \\
\mathrm{H}\end{array}$ & & & & & & & & & \\
\hline F-265 & $\begin{array}{l}473+50 \\
200 ' \text { LT }\end{array}$ & 0.5 & $\begin{array}{l}\text { A-4; VSt; } \\
\text { w }\end{array}$ & $\begin{array}{l}\text { Sandstone } \\
\text { MH }\end{array}$ & & & & & & & & & \\
\hline
\end{tabular}

